\title{
Evaluation of Monticello Nuclear Power Plant, Environmental Impact Prediction, Based on Monitoring Programs
}

\author{
by \\ K. L. Gore \\ J. M. Thomas \\ L. D. Kannberg \\ D. G. Watson
}

November 1976

Prepared for The Nuclear

Regulatory Commission 


\title{
NOTICE
}

This report was prepared as an account of work sponsored by the United States Government. Neither the United States nor the United States Nuclear Regulatory Commission, nor any of their employees, nor any of their contractors, subcontractors, or their employees, makes any warranty, express or implied, or assumes any legal liability or responsibility for the accuracy, completeness or usefulness of any information. apparatus, product or process disclosed, or represents that its use would not infringe privately owned rights.

\author{
PACIFIC NORTHWEST LABORATORY \\ operated by \\ BATTELLE \\ for the \\ ENERGY RESEARCH AND DEVELOPMENT ADMINISTRATION \\ Under Contract EY-76-C-06-1830
}

\begin{tabular}{|c|c|}
\hline \multicolumn{2}{|c|}{$\begin{array}{c}\text { Printed in the United States of Ame } \\
\text { Available from } \\
\text { National Technical Information Serv } \\
\text { U.S. Department of Commerce } \\
5285 \text { Port Royal Road } \\
\text { Springfield, Virginia } 22151\end{array}$} \\
\hline Price: Printed Copy & -*; Microfich \\
\hline *Pages & $\begin{array}{c}\text { NTIS } \\
\text { Selling Price }\end{array}$ \\
\hline $001-025$ & $\$ 4.50$ \\
\hline $026-050$ & $\$ 5.00$ \\
\hline 051-075 & $\$ 5.50$ \\
\hline 076-100 & $\$ 6.00$ \\
\hline $101-125$ & $\$ 6.50$ \\
\hline $126-150$ & $\$ 7.00$ \\
\hline $151-175$ & $\$ 7.75$ \\
\hline $176-200$ & $\$ 8.50$ \\
\hline $201-225$ & $\$ 8.75$ \\
\hline $226-250$ & $\$ 9.00$ \\
\hline $251-275$ & $\$ 10.00$ \\
\hline $276-300$ & $\$ 10.25$ \\
\hline
\end{tabular}




\title{
Evaluation of Monticello Nuclear Power Plant, Environmental Impact Prediction, Based on Monitoring Programs
}

\author{
by \\ K. L. Gore \\ J. M. Thomas \\ L. D. Kannberg \\ D. G. Watson
}

November 1976

Prepared for The Nuclear

Regulatory Commission

\section{Battelle}

Pacific Northwest Laboratories

Richland, Washington 993532 

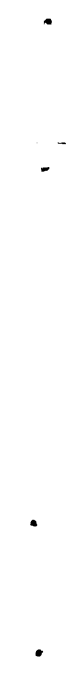


\section{ACKNOWLEDGMENTS}

We would like to extend our appreciation to Dave Heberling, Jim Bechthold and Larry Grotbeck of Northern States Power Company, Minneapolis, Minnesota for supplying us with pertinent information. Aiso, Dr. A. J. Hopwood and Dr. K. M. Knutson, Biology Department, St. Cloud St. College, Minnesota, were very helpful in gathering the data necessary for this report.

i. 


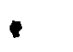

(

4

$v$ 
CONTENTS

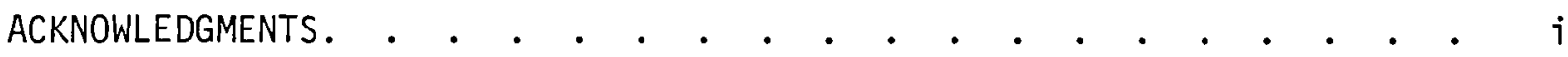

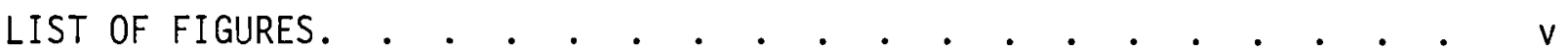

LIST OF TABLES • • • • • • • • • • • • • • • • • • • • • • • • •

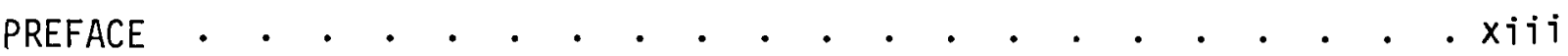

I. INTRODUCTION •

II. PLANT SITE AND HISTORY. • • • • • • • • • • • • • • • • • 3

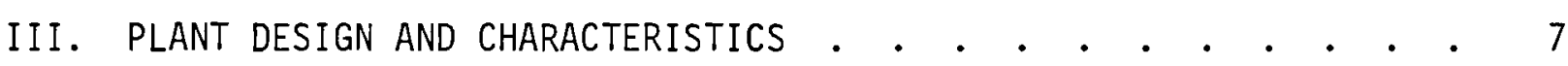

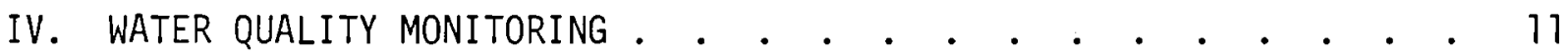

Temperature Monitoring Program . . . . . • . . . . . . 11

Preoperationa1. . . . . . . . . . . . . . . 11

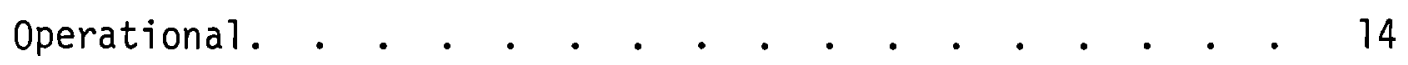

Water Chemistry, Preoperational and Operational (1968-1974) . 19

Prediction of the Thermal Regimes . . . . . . . . . . . 21

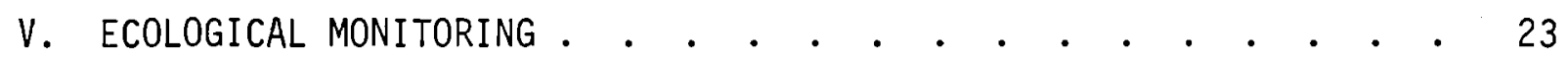

Preoperational Aquatic Ecology Monitoring . • • . • • . . 23

Periphyton (1968-1970) . . . . . . . . . . . . 23

Macroinvertebrates (1968-1970) • . • . • . . . . 25

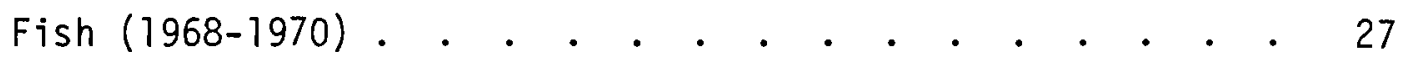

Operational Aquatic Ecology Monitoring . . . . . . . . 30

Periphyton (1971-1974) . . . . . . . . . . . . . 30

Macroinvertebrates $(1971-1974)$. . . . . . . . . . 31

Fish $(1971-1974)$. . . . . . . . . . . . . . . 36

Entrainment Studies . . . . . . . . . . . 39

Rationale for Data Synthesis . . . . . . . . . . . . . . . . 42 
Periphyton

Benthic Macroinvertebrates. . . . . . . . . . . 44

Impingement and Entrainment . . . . . . . . . . . 46

Electrofishing. . . . . . . . . . . . . . 46

Seining . . . . . . . . . . . . . . . 49

Creel Census Study . . . . . . . . . . . . . 49

Cold Shock Study. . . . . . . . . . . . . . . 49

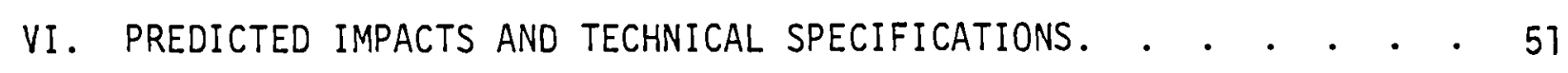

VII. ANALYSIS OF MONITORING DATA . . . . . . . . . . . . . 55

Thermal Monitoring . . . . . . . . . . . . . 55

Thermal Survey Results . . . . . . . . . . . . 55

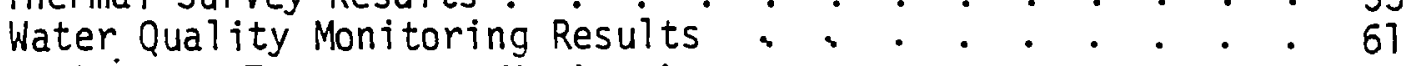

Periphyton Temperature Monitoring . . . . . . . . 65

Ecological Programs. . . . . . . . . . . . . . . 69

Benthos . . . . . . . . . . . . . . 69

Periphyton . . . . . . . . . . . . . . 86

Periphyton Productivity (Chlorophyll-a ) . . . . . 100

Fish Studies . . . . . . . . . . . . . 106

LITERATURE CITED. . . . • • • • • • • • • • • • 123

REFERENCES. . . . . . . • . . • . . • • • • • 125

APPENDIX A - ENVIRONMENTAL TECHNICAL SPECIFICATIONS • • • . . A.1

APPENDIX B - MONTHLY AVERAGE EXCESS BOTTOM TEMPERATURES • • • •

APPENDIX C - ORIGINAL BENTHOS DATA . . . . . . . . . . C.I

APPENDIX D - BENTHOS STATION RATIOS . . . . . . . . . . . D.

APPENDIX E - ORIGINAL PERIPHYTON DATA . . . . . . . . . E.1

APPENDIX F - LOGARITHM (BASE 10) OF TOTAL PERIPHYTON • • . . F.1

APPENDIX G - ORIGINAL PRIMARY PRODUCTIVITY DATA . . . . . . G.1

APPENDIX H - ELECTROFISHING DATA (CATCH/EFFORT) • • . . . . H.l 


\section{FIGURES}

Monticello Nuclear Generating Plant and Environs to Approximately 50 miles . . . . . . . 3 Gross Monthly Percent Power Generation . . . . . 5 Simplified Schematic of Plant Water Use . . . . . 7

4 Position of Water Temperature Recorders and Water Chemistry Stations in 1968 . . . . . . . . . . . 12

5 Thermal Plume Temperature Survey Measurement Transects and Stations . . . . . . . . . . . 15

6 Positon of Periphyton Artificial Substrates

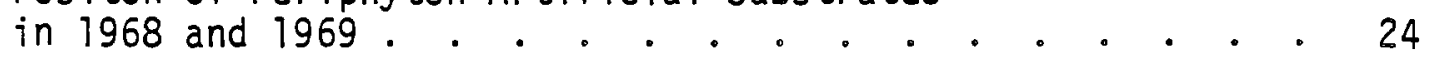

7 Position of Macroinvertebrate Bull Samplers in 1968 and Fish Electroshocking Sectors . . . . . . . . . 26

8 Position of Macroinvertebrate Concrete Block Samplers in 1969 . . . . . . . . . . . . . 27 Fish Seining Stations 1970-1970 . . . . . . . . . 29

10 Position of Periphyton Artificial Substrate Collectors - 1971

11 Position of Control and Experimental Stations for Benthic Colonization Study During 1971-1972 . . . . . . 32

12 Position of Macroinvertebrate Concrete Block

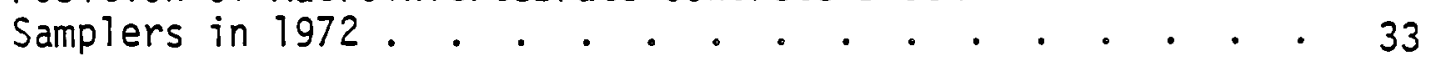

13 Position of Drift Insect Nets and Insect Light Traps in 1973-1974................. . 34

14 Position of Macroinvertebrate Concrete Block

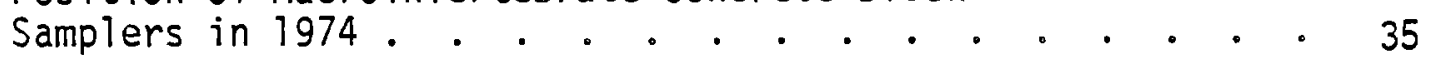

15 Position of Young-of-the-Year Fish Seining Stations, 1973-1974... . . . . . . . . . . 37

16 Diagram of Intake Structure and Sluice Canal for Impingement Canal

17 Fish Entrainment Capturing Device and Placement in Discharge Cana? 
19 Thermal Survey Surface Temperature Rise of $6 / 22 / 71$,

A River Flow of $4224 \mathrm{cfs}$, and an Excess Discharge

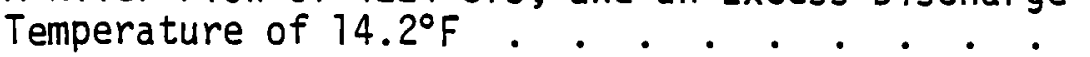

Surface Temperature Rise Predictions, August, Low

Flow, Helper Tower Operation . . . . . . . . . 58

21 Thermal Survey Surface Temperature Rise for $8 / 13 / 71$, a

River Flow of $1140 \mathrm{cfs}$, and an Excess Discharge Temperature of $11.3^{\circ} \mathrm{F}$

Surface Temperature Rise Predictions, August, Low Flow, Open Cycle Operation.

Thermal Survey Surface Temperature Rise for $8 / 19 / 71$, a River Flow of $1142 \mathrm{cfs}$, and an Excess Discharge Temperature of $24.9^{\circ} \mathrm{F}$

24 Surface Temperature Rise Predictions, January-February, Average Flow, Open Cycle Operation.

Thermal Survey Surface Temperature Rise for $2 / 23 / 72$, a River Flow of 3840 cfs, and an Excess Discharge Temperature of $29.3^{\circ} \mathrm{F}$

Vertical Thermal Structure at Downstream Cross-Sections . . 62

Excess Temperature Compared to Station 2 for March. . . . 64

Excess Temperature Compared to Station 2 for August . . . 64

Excess Temperature Compared to Station 2 for September . $\quad 65$

Illustration of Statistically Significant Differences

Among Control Stations for Hydropsyche and

Cheuma topsyche

32 Total Periphyton $\left(\log _{10}\right)$ with Distance from Canal Station 3 A for 1972.

Total Periphyton $\left(\log _{10}\right)$ with Distance from Canal Station 3 A for 1973.

Total Periphyton $\left(\log _{10}\right)$ with Distance from Canal Station 3 A for 1974. 
35 Comparison of Seasonal Relationship Between Mean Chlorophyl1-a for Heated Stations $(3,6,11)$ and Unheated Stations $(2,7,9)$. . . . . . . . . 102

36 Mean Chiorophyll-a for Three Replicate Slides Versus Their Respective Standard Deviation. . . . . . . 102

37 Rough Fish Catch/Unit Effort by Electrofishing - 1973 . • 110

38 Rough Fish Catch/Unit Effort by Electrofishing - 1974 . . 112

39 Fish Entrainment at Monticello . . . . . . . . . 119

40 Fish Impingement at Monticello . . . . . . . 120 
TABLES

Periods of Temperature Recording . . . . . . . . 13

Temperature Reporting Format Employed by NSP

for Water Quality Monitoring . . . . . . . . . 13

Location of Thermal Survey Transect Sites . . . . . . 16

$4 \quad$ River and Plant Operating Characteristics During

Thermal Plume Surveys . . . . . . . . . 18

5 Water Quality Monitoring Stations . . . • . . • . . 20

6 A List of Macroinvertebrate Sampling Cycles and

Substrate Placement and Recovery . . . . . . . . . 33

$7 \quad$ Summary of Periphyton Sampling and Analytical

Methods........ . . . . . . 43

8 Summary of Macroinvertebrates Samping and Analytical

Methods. . . . . . . . . . . . . . 45

9 Summary of Fish Sampling and Analytical Methods . . . 47

Summary of Entrainment Sampling and Analytical
Methods . . . . . . . . . . . . . . . . . . . . 48

11 Periphyton Monitoring Excess Temperature, ${ }^{\circ} \mathrm{F}$. . • • • 66

12 Periphyton Excess Temperature Ratios . • . • . • . • . 68

13 Thermal Status of Stations Within Transects . . . . . . 70

14 Statistical Model Used as an "Overview" of Each

Macroinvertebrate Group ............. . . . . 77

15 Results of Analysis of Variance of Abundance for

Six Macroinvertebrate Groups Reported . • . . . • . 72

16 An Example of the Calculation of One Interaction F-Test . . 74

$17 \begin{aligned} & \text { Schematic Example Calculation of Degrees of } \\ & \text { Freedom for F-Tests . . . . . . . . . . . . . . . . } 74\end{aligned}$

18 Comparison of Station Macroinvertebrate Counts

Using WiTcoxon's Signed-Ranks Test . . . . . . . . . 76 
19 Comparison of Preoperational and Operational Macro-

invertebrate Counts Using Wilcoxon's Signed-Rank Test. . . 77

20 Results of Macroinvertebrate One-Way Analys is of

Variance for Logarithms of Control/Site Station

Ratios Where Years are Treatments . . . . . . . 80

21 Comparison of Station Logarithmic Count Ratios by Month

for Preoperational and Operational Years . . . . . . 82

22 Comparison of Preoperational and Operationa 1

Logarithmic Microinvertebrate Ratios . . . . . . . 85

23 Times When Less than $75 \%$ of the Total Periphyton Were

Accounted for by the Twelve Species Considered . . . . 87

24 Periods of the Year When $75 \%$ or Less of the Total

Periphyton Were Accounted for by the Twelve Species

Considered.

Results of Wilcoxon's Signed-Ranks Tests for Periphyton

Numbers Where Stations 3,6, and 11 Were Subjected to

Thermal Additions . . . . . . . . . . . . . . 90

26 Summary of Wilcoxon's Signed-Ranks Tests for

Periphyton Numbers . . . . . . . . . • . . . . 91

27 Signed Differences in Periphyton Numbers Between Control

and Heated Periphyton Stations Found Significantiy Different

by Wiicoxon's Signed-Ranks Test . . . . . . . . . . 92

28 Summary of Regression Analysis of Total Periphyton

with Distance from Monticello Nuclear Power Plant . . . . 94

29 Results from One-Way Analyses of Variance of Log-

Transformed Total Periphyton . . . . . . . . . . 98

30 Average Chiorophy11-a for Heated and Unheated

Stations with Time . . . . . . . . . . . . . 101

31 Yearly Statistical Summary of Arithmetic

and Logarithmic Ratios of Chiorophyll-a for

Heated/Control Station Ratios. . . . . . . . . 104

32 Resuits from One-Way Analyses of Variance of Log-

Transformed Chlorophy 11-a Heated/Control for

Station Ratios 
33 Results from Fitting a Stepwise Multiple Regression

Model to Periphyton Productivity Data . . . . . . . 105

34 Electrofishing Catch Per Unit Effort in the Sector "A" . . 108

35 Electrofishing Catch Per Unit Effort in the Outer

Discharge Area . . . . . . . . . . . . . 108

36 Electrofishing Catch Per Unit Effort in the Intermediate

Discharge Zone (Within $3^{\circ} \mathrm{F}$ Isotherm) . . . . . 109

37 Electrofishing Catch Per Unit Effort in the Immediate

Discharge Zone (Within Discharge Canal) . . . . . 109

38 Number of Fish Caught Per Electrofishing Run for the

Period September 9, 1968 and October 4, 1968 . . . . . 110

39 Population Estimates of Smallmouth Bass,

Schnabel Method . . . . . . . . . . . . 111

40 Numbers of Fish Collected by Seining for Stations Fished

in 1970 and 1972-1973 . . . . . . . . . . . . 113

41 Percent of Fish.Collected by Seining in a Given

Sampling Run . . . . . . . . . . . . . . . 174

42 Interpolated Fish Impingement Data for 1973-1974 . . . . 116

43 Field Fish Entrainment Data for 1973-1974 . . . . . . . 117

44 Examples of Sampling Bias in the Fish

Impingement Program . . . . . . . . . . . . . . 118

45 Examples of Sampling Bias in the Fish

Entrainment Program . . . . . . . . . . . . 118 
•

.

2

v. 


\section{PREFACE}

In order to evaluate environmental programs conducted in conjunction with constructing and operating nuclear power plants, we selected three Environmental Impact Statements that we helped to prepare. The three plants selected, Monticel10, Haddam Neck, and Millstone, represent those which we believe had the best environmental programs. Our choice was based, in large part, on monitoring programs covering the longest time span. Thus, while the state-of-the-art of power plant monitoring has improved since the 1960 s to a point where these environmental programs may not appear to be "up-to-date," they were among the best of their period. We urge the reader to keep this in mind when reviewing this document. 

-

l. INTRODUCTION 

EVALUATION OF MONTICELLO NUCLEAR POWER PLANT

ENVIRONMENTAL IMPACT PREDICTION, BASED ON MONITORING PROGRAMS

\section{INTRODUCTION}

This report evaluates quantitatively the nonradiological environmental monitoring programs at Monticel10 Nuclear Generating Plant. The general objective of the study is to assess the effectiveness of monitoring programs in the measurement of environmental impacts. Specific objectives include the following:

- Assess the validity of environmental impact predictions made in the Environmental Statement by analysis of nonradiological monitoring data.

- Evaluate the general adequacy of environmental monitoring programs for detecting impacts and their responsiveness to Technical Specifications objectives.

- Assess the adequacy of preoperational monitoring programs in providing a sufficient data base for evaluating operational impacts.

- Identify possible impacts that were not predicted in the environmental statement and identify monitoring activities that need to be added, modified or deleted.

- Assist in identifying environmental impacts, monitoring methods, and measurement problems that need additional research before quantitative predictions can be attempted.

In this report preoperational as well as operational monitoring data were examined to test the usefulness of baseline information in evaluating impacts. This included an examination of the analytical methods used to measure ecological and physical parameters, and an assessment of sampling periodicity and sensitivity where appropriate data were available. 
This study is largely dependent on current statistical methodologies and new methods being developed at Battelle, Pacific Northwest Laboratories (PNL). A considerable amount of time was spent accumulating the basic data and preparing it for analyses.

In a final report that combines the results from three separate nuclear plants our efforts will be directed toward addressing the following questions: 1) are monitoring programs an effective way to assess environmental impacts, 2) can predicted impacts be verified by monitoring programs, and 3) do monitoring programs satisfy the requirements of the Technical Specifications? Answers to these questions should delineate deficiencies in preoperational and operational monitoring procedures and provide bases for improvements. 


\section{PLANT SITE AND HISTORY}





\section{PLANT SITE AND HISTORY}

The Monticello Nuclear Generating Plant is located on the Mississippi River about $4.8 \mathrm{~km}$ northwest of the town of Monticello, Wright County, Minnesota. I.t is approximately $56 \mathrm{~km}$ northwest of St. Paul, Minneapolis, and about $40 \mathrm{~km}$ southeast of St. Cloud, Minnesota (Figure 1). The area around the site is mostly rural with the land used primarily for farming. The site lies on the outwash plain of the Mississippi River. Elk River, which flows parallel to the Mississippi River about $6 \mathrm{~km}$ north of the plant and connects with the Mississippi River about $24 \mathrm{~km}$ downstream, is the principal tributary nearest the site.

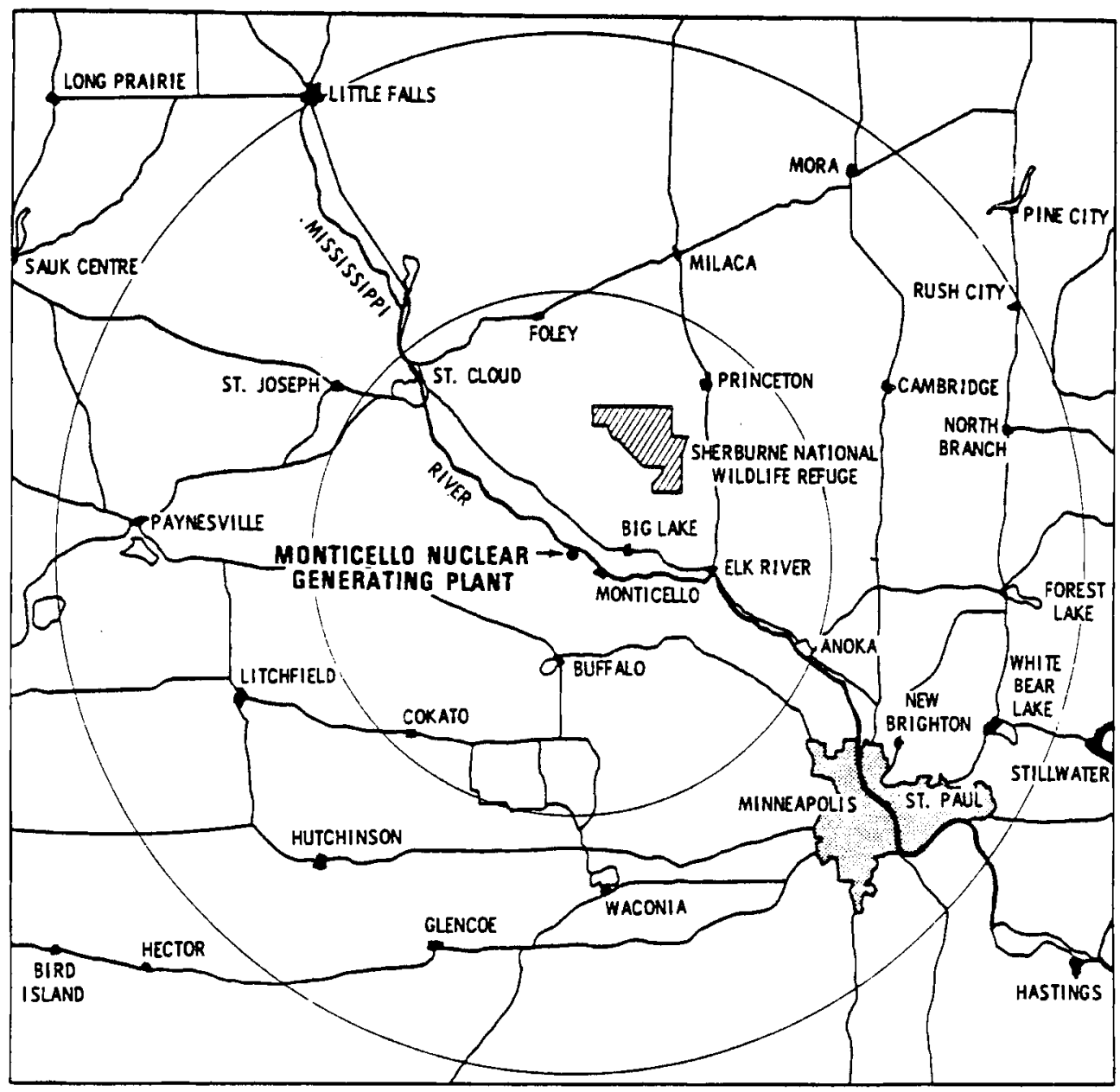

FIGURE 1. Monticello Nuclear Generating Plant and Environs to Approximately 50 Miles 
Maximum and minimum flows for the river near the site are 54,000 cfs $\left(1,529 \mathrm{~m}^{3} / \mathrm{sec}\right)$ and $240 \mathrm{cfs}\left(7 \mathrm{~m}^{3} / \mathrm{sec}\right)$, respectively with average flow of $4,600 \mathrm{cfs}\left(130 \mathrm{~m}^{3} / \mathrm{sec}\right)$. Based on flow duration data, the flow is expected to exceed $1,800 \mathrm{cfs}\left(51 \mathrm{~m}^{3} / \mathrm{sec}\right) 90 \%$ of the time and $950 \mathrm{cfs}\left(72 \mathrm{~m}^{3} / \mathrm{sec}\right)$ $99 \%$ of the time. Average flow velocities vary between $1.5(0.15 \mathrm{~m} / \mathrm{sec})$ and $2.5 \mathrm{fps}(0.8 \mathrm{~m} / \mathrm{sec})$ for flows below $10,000 \mathrm{cfs}\left(283 \mathrm{~m}^{3} / \mathrm{sec}\right)$. Monthly river temperatures range between freezing and $85^{\circ} \mathrm{F}\left(29.5^{\circ} \mathrm{C}\right)$.

The aquatic biota near the Monticello Plant consists mainly of periphytic algae, benthic invertebrates and fish. Primary produers are mainly attached algae (diatoms, greens and blue-greens) with vascular plants being scarce. The invertebrates are characterized by caddisflies (Trichoptera) and mayflies (Ephemeroptera) which inhabit the flowing areas of the river. Dipterans, isopods and beetles are the dominant organisms found in the slack water areas of the river. The aquatic population is dominated by coarse fish. Carp and redhorse suckers were the most numerous fish captured by electrofishing methods with shiners dominating the seining collections. Game fish include: walleye, smallmouth bass, crappie, rock bass and northern pike.

In April 1966, Northern States Power Company (NSP) formally applied to the AEC (now Nuclear Regulatory Commission (NRC)) for permission to construct a nuclear power generating facility near Monticello, Minnesota, that would become operative in May 1970. After local hearings in the county seat, the AEC granted a construction permit to NSP on 19 June 1967. During the second half of the 1967 calendar year, the State of Minnesota raised questions concerning regulation of thermal and radioactive discharges to Minnesota water bodies and by May 1969 issued a permit to NSP with State regulatory statutes included. NSP questioned the authority of the State to regulate radioactive wastes and placed this matter before the Federal courts. In August 1969, the Federal Courts ruled that only the Federal Government has the right to regulate radioactive releases from nuclear generating facilities. 
In April 1970, AEC opened public hearings on NSP's application for an operating permit and in September 1970 issued a provisional low power operating license. On 18 February 1971, Monticel10 Plant received final authority from AEC to operate at full power. Since February 1971 the plant has been averaging better than $70 \%$ full power level, except for times when the plant was shut down for refueling. Figure 2 graphicaliy depicts monthly power levels for years 1971 through 1974.

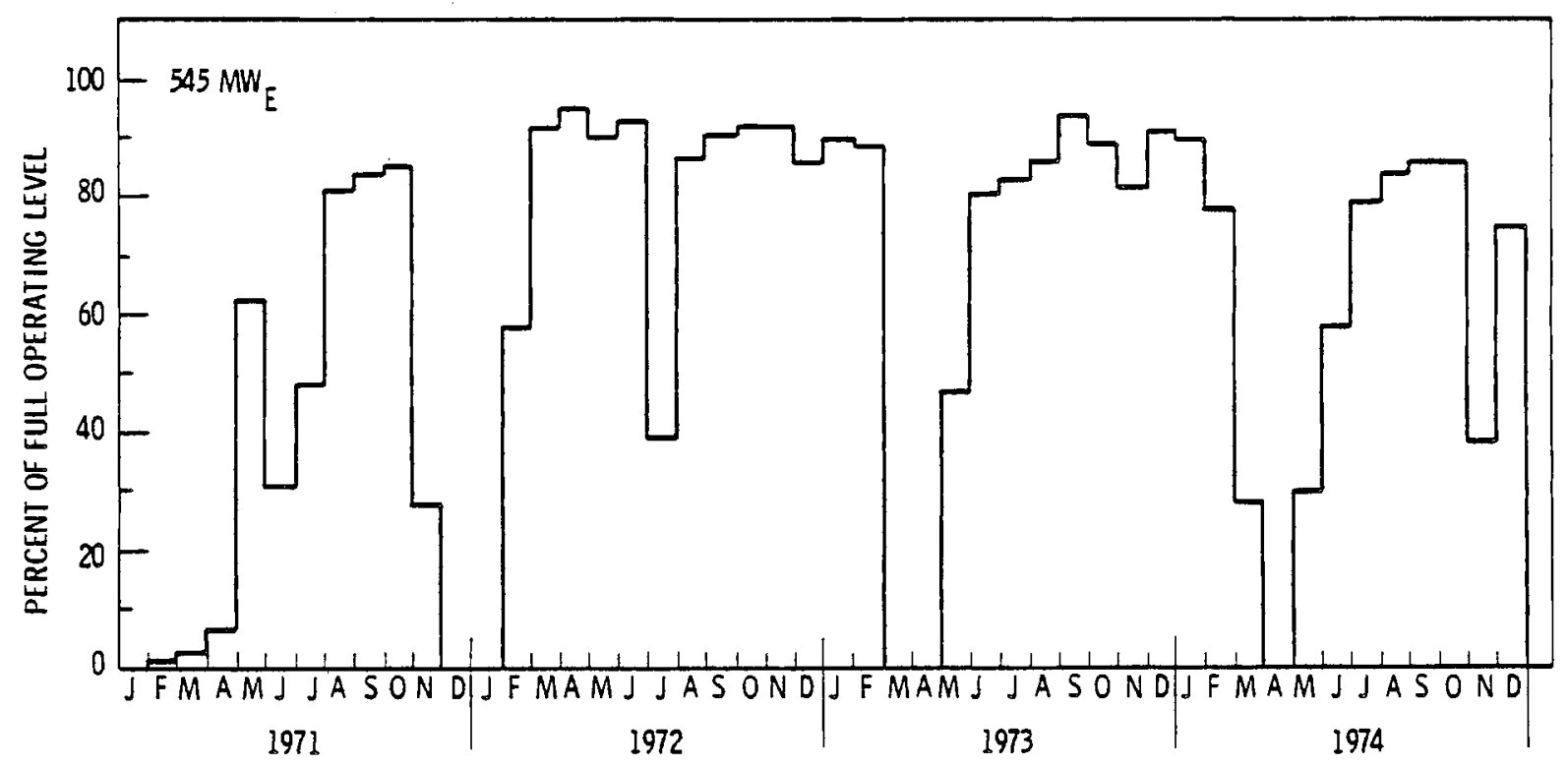

FIGURE 2. Gross Monthly Percent Power Generation 

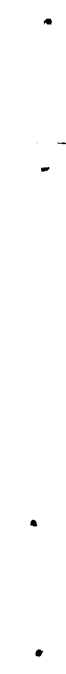
III. PLANT DESIGN AND CHARACTERISTICS 

The Monticello Plant uses a single cycle, forced-circulation boiling water reactor designed for operation at power levels up to 1670 MWt and 545 MWe. The reactor core utilizes four modules assembled around a crucified control rod. Enriched uranium dioxide pellets sealed in Zircaloy tubes serve as the fuel for the reactor. Water is both the moderator and coolant for the reactor core. Water enters the bottom of the core and flows upward through the fuel assemblies to produce steam from boiling. This mixture of water-steam is separated by steam separators and dryer assemblies within the reactor vessel. The steam is passed through the main steam lines to the turbine; whereas, the water is mixed with the incoming main feed-water line and recirculated (Figure 3 ). The condenser is a single pass, dual pressure, deaerating type with water supplied from the river to remove the excess heat.

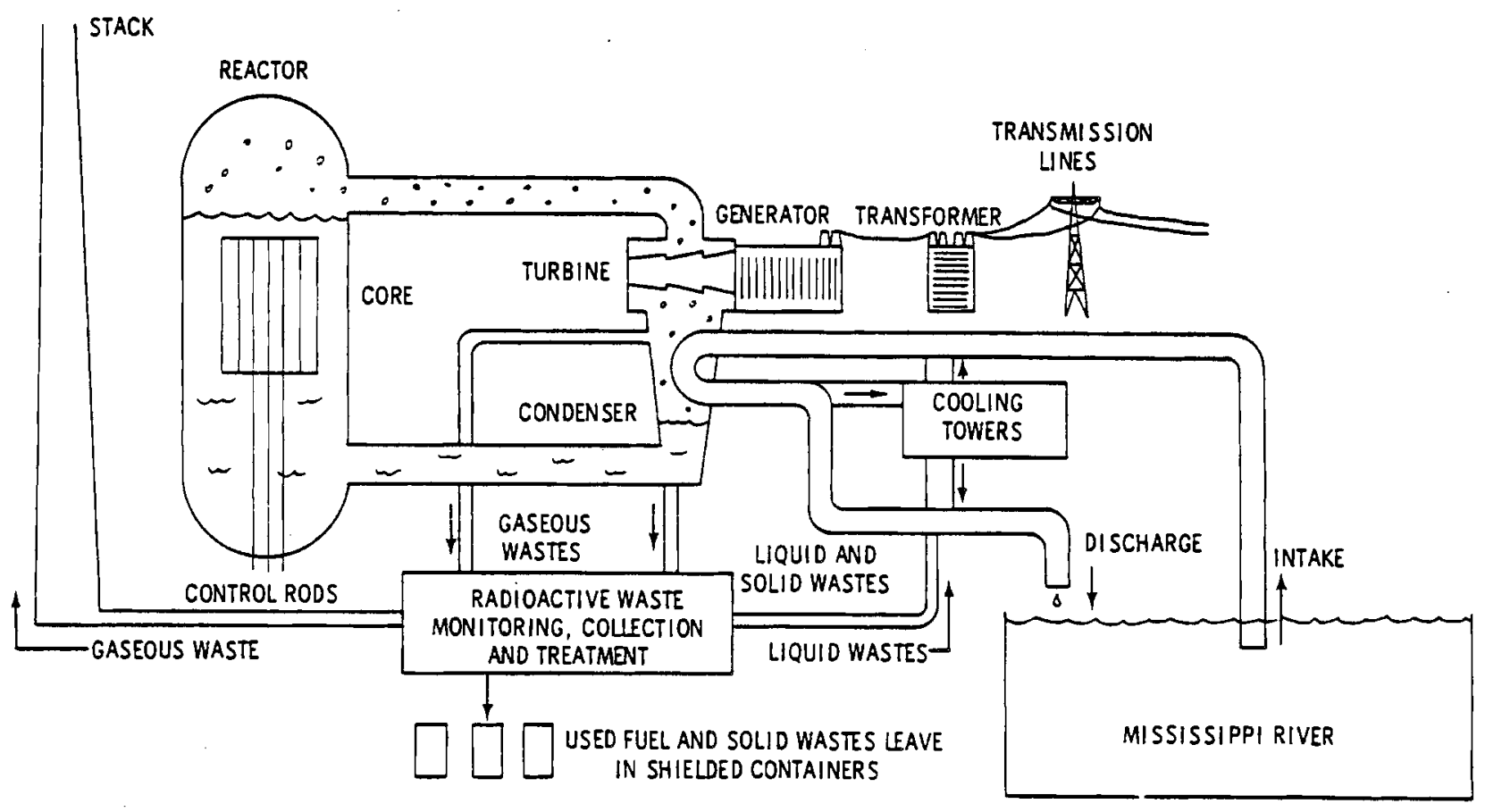

FIGURE 3. Simplified Schematic of Plant Water Use 
The circulating water system consists of an intake structure, circulating pumps, condenser-helper cooling towers and discharge structure. The intake structure is located inland from the bank of the Mississippi River at the end of a short $(46 \mathrm{~m})$ intake canal. The canal is about $19 \mathrm{~m}$ wide. Water is withdrawn from the river at approximately $645 \mathrm{cfs}\left(18 \mathrm{~m}^{3} / \mathrm{sec}\right)$ passes through trash racks that retain large pieces of debris, and then through two traveling screens of $9.5 \mathrm{~mm}$ diameter. Water velocity in the intake canal is about $0.5 \mathrm{fps}(0.15 \mathrm{~m} / \mathrm{sec})$, whereas, approach velocities to the traveling screens are less than 1 fps $(0.3 \mathrm{~m} / \mathrm{sec})$. Water travels through the screens to the service water pump bays where the circulating water pumps (two half capacity pumps) circulate the water through the condensers. The service water pump bays are divided by a center wall to allow dewatering of either bay and provide dry access to the traveling screens independently of each other. At full plant design load, the water that passes through the main condensers is raised about $27^{\circ} \mathrm{F}\left(15^{\circ} \mathrm{C}\right)(\Delta T)$ above the intake temperature but can vary up to $50^{\circ} \mathrm{F}\left(28^{\circ} \mathrm{C}\right)$. From the condensers, the water can be directed into the river via a discharge canal or diverted to the mechanical draft cooling towers for further c00ling before being discharged to the river. Cooling water passes over two motor operated sluice gates and into a $305 \mathrm{~m}$ long discharge canal where the heated effluent is returned to the river downstream of the intake structure. Cooling tower blowdown enters the discharge canal just below the discharge structure. To control winter icing of the water intake, heated water from the condensers can be routed back to the intake.

The four modes of water circulation are as follows:

\section{- Open Cycle}

Water is withdrawn from the river at the rate of 645 cfs $\left(18 \mathrm{~m}^{3} / \mathrm{sec}\right)$, passed through the condensers and returned to the river via the discharge canal. Total transit time through the plant and discharge canal is 15 minutes. 
- $\quad$ Helper Cycle

This mode is essentially the same as open cycle except all or a portion of the cooling water effluent is diverted through mechanical cooling towers before being discharged back into the river. The same volume of water (645 cfs) is withdrawn and only the volume lost through evaporation in the cooling towers is not returned to the river. Total transit time through the plant cooling towers and discharge canal is about 18 minutes.

- Recirculation Cycle

In this mode only a portion of the total circulating water is withdrawn from the river. Most of the cooling water is recirculated and only the volume of water withdrawn is returned to the river minus cooling tower evaporative losses.

- $\quad$ Closed Cycle

This mode allows for a maximum quantity of water to be recirculated. About $54 \mathrm{cfs}\left(15 \mathrm{~m}^{3} / \mathrm{sec}\right)$ is withdrawn and $36 \mathrm{cfs}$ $\left(1 \mathrm{~m}^{3} / \mathrm{sec}\right)$ is discharged and about $18 \mathrm{cfs}\left(0.5 \mathrm{~m}^{3} / \mathrm{sec}\right)$ is lost to evaporation. Only the blowdown water is returned to the river.

The cooling tower operation is required only when the river flows are insufficient to supply adequate cooling water due to appropriation restrictions and/or to comply with regulations limiting the amount of heat discharged to the river. The State of Minnesota has set the following limitations on the discharge of heated water (State of Minnesota, 1969):

"Cooling facilities shall be provided and operated to insure that the heat content of the cooling water after reasonable dilution and mixing in the river does not raise the temperature of the river above limits specified below: 


\begin{tabular}{|c|c|c|}
\hline Period & \multicolumn{2}{|c|}{ Maximum Temperature } \\
\hline July through August & $86^{\circ} \mathrm{F}\left(30^{\circ} \mathrm{C}\right)$ & or $5^{\circ} \mathrm{F}\left(2.8^{\circ} \mathrm{C}\right)$ above \\
\hline June through September & $80^{\circ} \mathrm{F}\left(27^{\circ} \mathrm{C}\right)$ & $\begin{array}{l}\text { the ambient tempera- } \\
\text { ture of the river } \\
\text { whichever is areater. }\end{array}$ \\
\hline May through October & $67^{\circ} \mathrm{F}\left(19.5^{\circ} \mathrm{C}\right)$ & $\begin{array}{l}\text { except that in no case } \\
\text { shall the river tem- }\end{array}$ \\
\hline April though November & $55^{\circ} \mathrm{F}\left(13^{\circ} \mathrm{C}\right)$ & $\begin{array}{l}\text { perature be raised } \\
\text { above } 90^{\circ} \mathrm{F} \text { by the dis- }\end{array}$ \\
\hline March through December & $43^{\circ} \mathrm{F}\left(6^{\circ} \mathrm{C}\right)$ & $\begin{array}{l}\text { charge of this } \\
\text { effluent. }\end{array}$ \\
\hline January through February & $37^{\circ} \mathrm{F}\left(3^{\circ} \mathrm{C}\right)$ & \\
\hline
\end{tabular}

Although it is not necessary to operate the cooling towers much of the year, Northern States Power Company has been operating the towers to the maximum extent practicable. The cooling towers are not designed for wintertime operation. 
IV. WATER QUALITY MONITORING 



\section{WATER QUALITY MONITORING}

River temperature information has been gathered by three separate measurement programs. The goals of each program were different and, hence, the type of information differs. Of these three sources of information, one is both preoperational and operational, the other two are operational.

\section{TEMPERATURE MONITORING PROGRAM}

\section{PREOPERATIONAL}

Both preoperational and operational temperature data were continuously collected at nine stations as part of the water quality monitoring. Two stations were established upstream of the plant and seven stations downstream (Figure 4). The temperature monitoring program began in July 1969 and continued until January 1973 (Station 9 was discontinued in 1971). Temperatures were measured with 7-day air temperature compensating Palmer ${ }^{(B)}$ recording thermometers (accuracy $\pm 0.5^{\circ} \mathrm{F}$ ) mounted on shore with the sensor lashed to a cement anchoring block positioned 18 to $27 \mathrm{~m}$ from the right side of the river. Weekly average maximum, average minimum, and the extreme temperatures encountered during each 7-day period were reported. The periods of operation for each station are given in Table 1. A sample of the reporting format is shown in Table 2.

Use of brand name does not imply Battelle endorsement. 


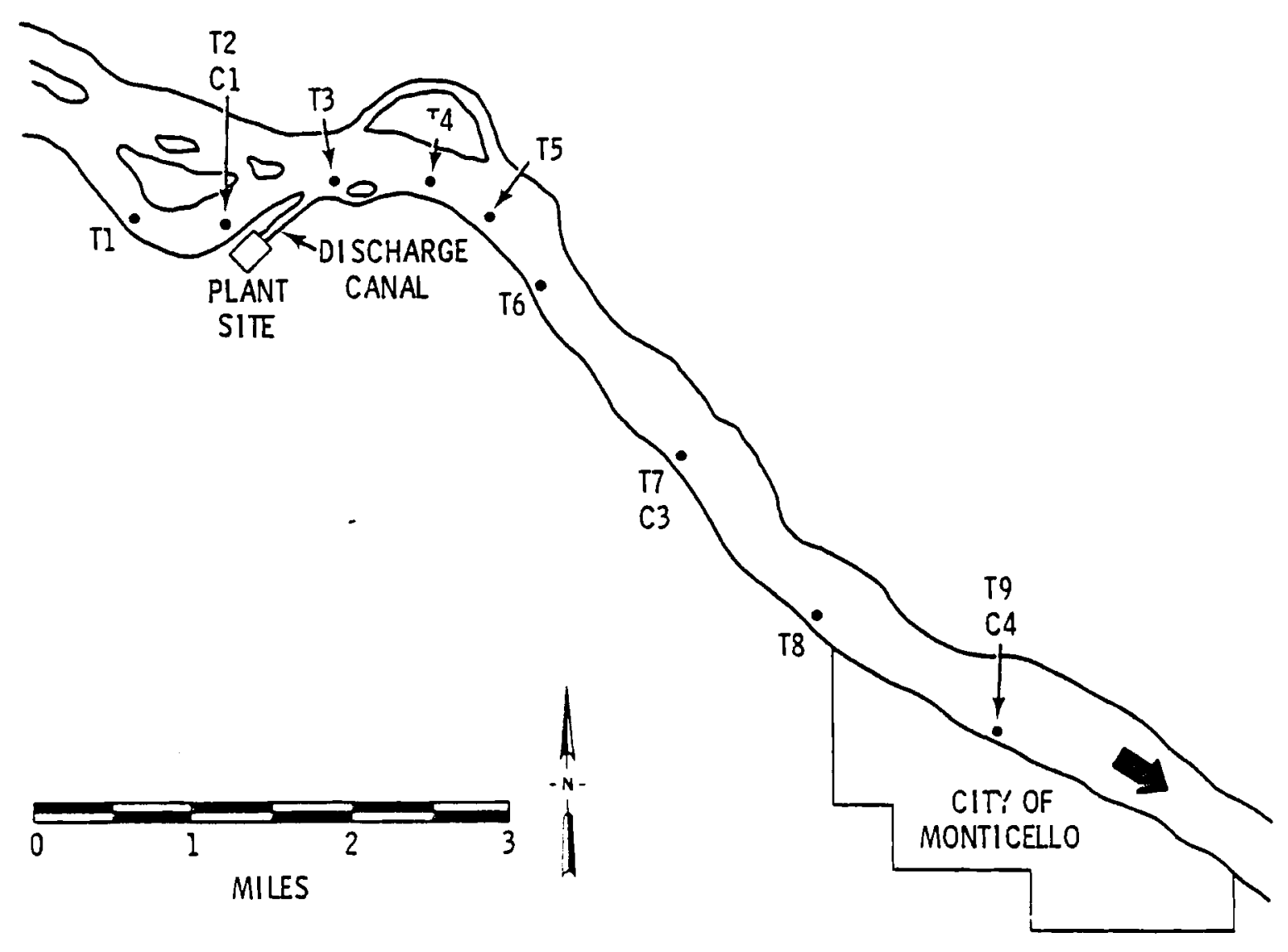

FIGURE 4. Position of Water Temperature Recorders $(T)$ and Water Chemistry Stations (C) in 1968 (See Table 1 for locations of invertebrate sampling locations) 


\section{TABLE 1. Periods of Temperature Recording}

\begin{tabular}{|c|c|c|c|c|c|c|c|c|c|}
\hline Year & Station 1 & Station 2 & Station 3 & Station 4 & Station 5 & Station 6 & Station $?$ & Station 8 & Station 9 \\
\hline 1969 & $7-5 / 12-31$ & $7-5 / 72-31$ & $7-5 / 12-31$ & $7-12 / 12-31$ & $7-12 / 11-15$ & $7-5 / 12-31$ & $7-5 / 12-5$ & $\begin{array}{l}7-5 / 7-25 \\
8-3 / 12-31\end{array}$ & $7 \cdot 5 / 12=$ \\
\hline 1970 & $4-30 / 12-31$ & $2-20 / 12-31$ & $\begin{array}{l}2-26 / 4-23 \\
5-7 / 72-31\end{array}$ & $\begin{array}{l}1-29 / 8-19 \\
8-27 / 9-2 \\
9-10 / 11-25 \\
12-31 /\end{array}$ & $7-30 / 12-31$ & $\begin{array}{l}4-30 / 12-9 \\
12-17 / 12-31\end{array}$ & $\begin{array}{l}2-26 / 5-20 \\
5-28 / 12-17\end{array}$ & $\begin{array}{l}4-30 / 7-15 \\
7-23 / 11-11 \\
11-19 / 12-31\end{array}$ & $\begin{array}{l}8-13 / 8-2 \\
9-3 / 10- \\
12-10 / 12-\end{array}$ \\
\hline 1971 & $\begin{array}{l}1-1 / 2-3 \\
2-11 / 3-24 \\
6-17 / 12-31\end{array}$ & $1-1 / 12-31$ & $\begin{array}{l}1-1 / 4-8 \\
8-26 / 12-31\end{array}$ & $\begin{array}{l}1-1 / 7-22 \\
8-26 / 11-25 \\
12-16 / 12-31\end{array}$ & $\begin{array}{l}1-1 / 1-20 \\
2-28 / 12-31\end{array}$ & $1-1 / 12-31$ & $\begin{array}{c}\text { Out all } \\
\text { Year }\end{array}$ & $\begin{array}{l}1-1 / 1-20 \\
1-28 / 4-7 \\
7-22 / 9-8 \\
9-23 / 11-3 \\
12-2 / 12-23\end{array}$ & $\begin{array}{c}\text { Out all } \\
\text { Year }\end{array}$ \\
\hline 1972 & $\begin{array}{l}1-1 / 1-19 \\
1-20 / 12-12\end{array}$ & $1-1 / 12-19$ & $\begin{array}{l}1-1 / 2-9 \\
2-17 / 11-30\end{array}$ & $1-1 / 12-5$ & $\begin{array}{l}1-1 / 1-5 \\
4-6 / 4-20 \\
6-15 / 7-5 \\
7-27 / 12-5\end{array}$ & $1-1 / ?-20$ & $\begin{array}{l}6-15 / 7-5 \\
7-13 / 8-23 \\
9-7 / 11-29\end{array}$ & $6-1 / 11-29$ & $\begin{array}{c}\text { Out all } \\
\text { Year }\end{array}$ \\
\hline
\end{tabular}

TABLE 2. Temperature Reporting Format Employed by NSP for Water Quality Monitoring

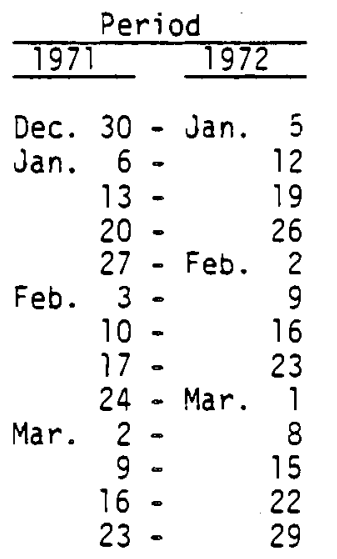

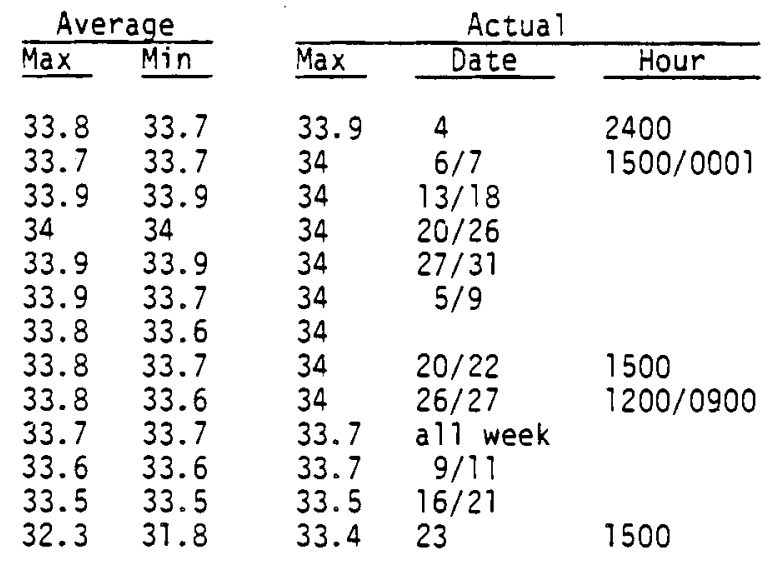

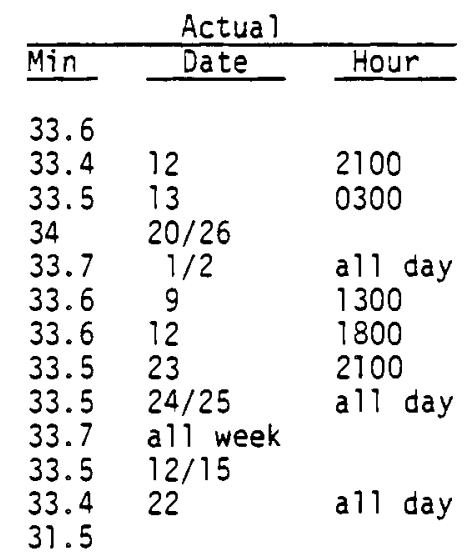


OPERATIONAL

Two programs provided river temperature information; one to determine the thermal regimes downstream from the plant for different cooling modes and the other to support the periphyton monitoring program.

On 34 occasions during 1971 to 1973 thermal plume surveys were performed. Only results from the first 13 surveys were available for this review. The survey techniques are detailed in Supplement 1 to the Environmental Report. A summary of the essential elements of the program are given below.

Thermal plume temperatures were taken in a vertical and lateral crosssection grid at 19 locations (16 of which were downstream of the discharge). For each of these 19 transect points, 7 equally spaced lateral positions across the river were established where the temperature was measured at each $0.3 \mathrm{~m}$ depth interval from the water surface to $0.15 \mathrm{~m}$ from the bottom. Temperature measurements were made with thermisters (accuracy of final - readings was estimated at $\pm 0.5^{\circ} \mathrm{F}$ ). On each survey, data measurements began at a transect $91 \mathrm{~m}$ upstream from the intake structure, and proceeded to the transects downstream. The locations of the measurement transects are shown in Figure 5 and described in Table 3. During each survey, the plant operating load and cooling mode were kept constant, the intake and discharge temperatures were continuously monitored, and wet and dry bulb temperatures were taken hourly. Temperatures measured downstream of the discharge were corrected for variation in water temperature at the intake. Vertical, horizontal, and surface isotherm contours were then estimated and plotted for each transect.

Additional information reported for each of the first 13 surveys included:

- Average intake temperature at start of survey.

- Average intake temperature at end of survey.

- Median intake temperature.

- Average condenser intake temperature.

- Average condenser discharge temperature. 

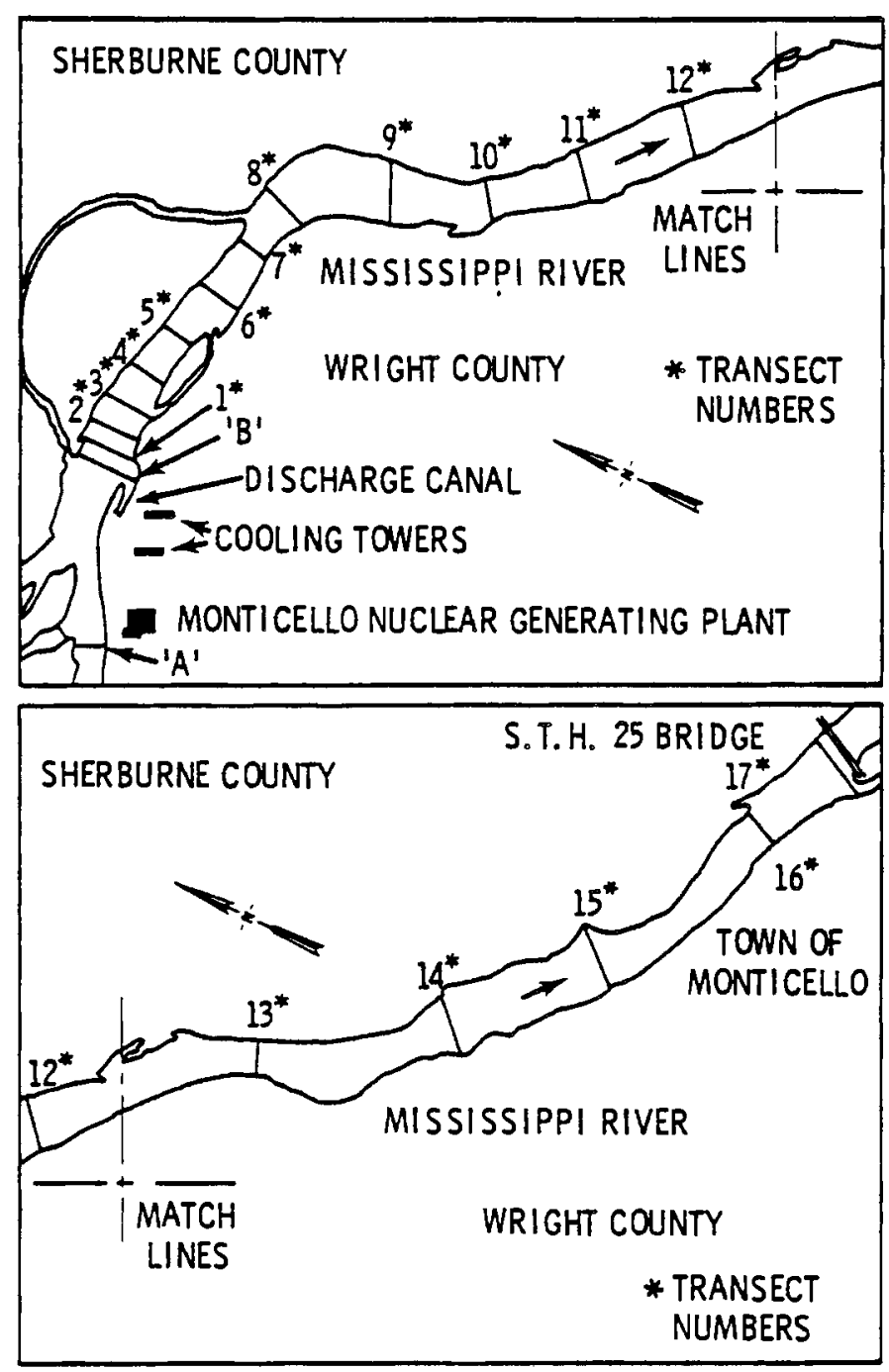

FIGURE 5. Thermal Plume Temperature Survey Measurement Transects and Stations 
TABLE 3. Location of Thermal Survey Transect Sites

Transect

Designation

Location

A

B

$300 \mathrm{ft}(91 \mathrm{~m})$ upstream from intake

In discharge canal and river $50 \mathrm{ft}$

$(15 \mathrm{~m})$ ups tream from Station 1.

At discharge to river

$200 \mathrm{ft}(61 \mathrm{~m})$ downstream from discharge

$500 \mathrm{ft}(152 \mathrm{~m})$ downstream from discharge

$900 \mathrm{ft}(274 \mathrm{~m})$ downstream from discharge

, $400 \mathrm{ft}(426 \mathrm{~m})$ downstream from discharge

$2,000 \mathrm{ft}(610 \mathrm{~m})$ downs tream from discharge

$2,600 \mathrm{ft}(792 \mathrm{~m})$ downstream from discharge

8

$3,200 \mathrm{ft}(975 \mathrm{~m})$ downstream from discharge

$4,400 \mathrm{ft}(1,341 \mathrm{~m})$ downstream from discharge

$5,450 \mathrm{ft}(1,661$

m) downstream from discharge

$6,500 \mathrm{ft}(1,981$

m) downstream from discharge

$7,700 \mathrm{ft}(2,347 \mathrm{~m})$ downstream from discharge

m) downstream from discharge

m) downstream from discharge

m) downstream from discharge

m) downstream from discharge

$17,450 \mathrm{ft}(5,319 \mathrm{~m})$ downstream from discharge 
- Average dry bulb temperature.

- Average wet bulb temperature.

- Average intake temperature.

- Average canal discharge temperature.

- Average plant load.

- Discharge flow to river.

- Average percent cloud cover.

- Average wind velocity.

- Average wind direction.

- River flow (or elevation at plant).

- Cooling mode characteristics (which tower is on, how many fans, etc.).

The calendar dates, average intake and discharge canal temperature, average plant load, discharge flow, river flow, and cooling mode characteristics are given in Table 4 for the thermal plume surveys.

Other operational river temperature data were collected during the periphyton monitoring program from June 1971 through 1974. The period receiving the greatest attention was from April through November. During that time, river temperature was measured at varying numbers of stations (see Ecological Monitoring - Periphyton). There was at least one station upstream and one in the discharge canal, the rest being downstream of the discharge. The measurements were momentary temperatures taken with a mercury thermometer at a depth of $20 \mathrm{~cm}$. There was no adjustment of downstream temperatures for diurnal temperature variation. The lateral position of the sampling points was described as either in the plume or out of it. 
TABLE 4. River and Plant Operating Characteristics During Thermal Plume Surveys

\begin{tabular}{|c|c|c|c|c|c|c|}
\hline $\begin{array}{l}\text { Survey } \\
\text { Date }\end{array}$ & $\begin{array}{l}\text { Average } \\
\text { Intake } \\
(\circ \mathrm{F}) \\
\end{array}$ & $\begin{array}{c}\text { Average Canal } \\
\text { Discharge } \\
\left({ }^{\circ} \mathrm{F}\right) \\
\end{array}$ & $\begin{array}{l}\text { Average } \\
\text { Plant } \\
\text { Load, MW }\end{array}$ & $\begin{array}{l}\text { Discharge } \\
\text { Flow, cfs }\end{array}$ & $\begin{array}{l}\text { River Flow, } \\
\text { efs } \\
\end{array}$ & $\begin{array}{c}\text { Cooling Operation } \\
\text { During Survey }\end{array}$ \\
\hline $6 / 22 / 71$ & 76.2 & $9 n .4$ & 560 & 555 & 4,224 & Both towers in service \\
\hline $7 / 1 / 71$ & 73.3 & 87.9 & 567 & 565 & 6,234 & Once through \\
\hline $7 / 6 / 71$ & 76.8 & 99.3 & 552.4 & 561 & 4,533 & Both towers in service \\
\hline $8 / 2 / 71$ & 67.1 & 80.5 & 518.8 & 529 & 2,048 & Both towers in service \\
\hline $8 / 3 / 71$ & 68.2 & 92.1 & 521.3 & 606 & 2,048 & Once through \\
\hline $8 / 13 / 71$ & 74.3 & 85.6 & 510.0 & 509.8 & 1,140 & $\begin{array}{l}\text { Both towers in service } \\
\text { one fan off }\end{array}$ \\
\hline $8 / 19 / 71$ & 77.9 & 102.8 & 508.2 & 585 & 1,142 & Once through \\
\hline $9 / 2 / 71$ & 74.1 & 85.8 & 480 & 636 & 1,536 & Both in service \\
\hline $9 / 20 / 71$ & 60.8 & 74.2 & 508.6 & 633 & 1,215 & Partial helper cycle \\
\hline $11 / 9 / 71$ & 35.2 & 61.5 & 523.8 & 208 & 18,656 & Partial recirculation \\
\hline $2 / 22 / 72$ & 32.3 & 82.4 & 556.7 & 320 & 3,840 & Once through \\
\hline $2 / 23 / 72$ & 33.2 & 62.5 & 560.8 & 640 & 3,840 & Once through \\
\hline $3 / 1 / 72$ & 32.3 & 60.3 & 530 & 623.9 & 3,840 & Once through \\
\hline $4 / 4 / 72$ & 33.0 & 77.3 & 580 & 323.1 & $909^{(1)}$ & Once through \\
\hline $5 / 23 / 72$ & 70.4 & 83.5 & 570 & -- & $909^{(1)}$ & Once through \\
\hline $6 / 22 / 72$ & 68.5 & 99.2 & 568.5 & 623.9 & 5,550 & Once through \\
\hline $7 / 5 / 72$ & 70.2 & 90.6 & 566.4 & 623.9 & 3,755 & \\
\hline $8 / 3 / 72$ & --- & 80.1 & 455.8 & --- & 18,901 & Both towers in service \\
\hline $8 / 14 / 72$ & --- & 86.6 & 562.7 & 654.0 & 16,960 & Both towers in service \\
\hline $8 / 18 / 72$ &.- & 88.8 & 563 & 623.9 & 14,450 & Both towers in service \\
\hline $8 / 23 / 72$ & -- & 82.4 & 565.4 & 635 & 14,200 & Both towers in service \\
\hline $8 / 30 / 72$ & -- & 86.5 & 566.8 & 630 & 14,976 & Both towers in service \\
\hline $9 / 7 / 72$ & -- & 94.1 & 566.8 & 596 & 10,750 & Once through \\
\hline $9 / 15 / 72$ & -- & 94.2 & 566.5 & 581.3 & 6,656 & Once through \\
\hline $6 / 19 / 73$ & -- & 73.6 & -- & -- & 1,790 & Shutdown \\
\hline $6 / 27 / 73$ & -- & 92.6 & 572.4 & 24.3 & 2,410 & $\begin{array}{l}\text { One tower bank now in } \\
\text { service }\end{array}$ \\
\hline $7 / 2 / 73$ & --- & 85.8 & 543.7 & 375.5 & 1,790 & Both towers in service \\
\hline $7 / 5 / 73$ & -- & 86.3 & 543.2 & --- & 2,276 & Both towers in service \\
\hline $7 / 12 / 73$ & -- & 89.6 & 538.1 & 581.0 & 2,155 & Both towers in service \\
\hline $7 / 16 / 73$ & --- & 84.6 & 545.2 & 577.3 & 1,920 & Both towers in service \\
\hline $7 / 19 / 73$ & -- & 86.8 & 498.3 & 551.5 & 2,219 & Both towers in service \\
\hline $7 / 25 / 73$ & $\ldots$ & 89.0 & 541.6 & 580 & 1,792 & Both towers in service \\
\hline $7 / 30 / 73$ & $-\cdot-$ & 82.1 & 544.1 & 577.7 & 2,410 & Both towers in service \\
\hline $8 / 13 / 73$ & -- & 86.7 & 545.5 & 590.0 & 5,376 & Partial tower service \\
\hline
\end{tabular}

(1)Flow not available; only water elevation. 


\section{WATER CHEMISTRY, PREOPERATIONAL \\ AND OPERATIONAL (1968-1974)}

In 1968, water samples were taken at the same seven stations used for temperature data (Figure 4). Analyses were according to procedures found in Standard Methods (1960). Samples were collected biweekly throughout the year for 34 parameters; $B O D$ and DOS were measured monthly. The parameters included total solids, dissolved solids, suspended solids, total hardness, $\mathrm{Ca}$ hardness, Mg hardness, bicarbonate, carbonate and hydroxide alkalinity, free $\mathrm{CO}_{2}, \mathrm{H}_{2} \mathrm{~S}, \mathrm{NH}_{4}, \mathrm{CO}_{3}, \mathrm{HCO}_{3}, \mathrm{OH}, \mathrm{Cl}, \mathrm{SO}_{4}, \mathrm{PO}_{4}, \mathrm{NO}_{3}, \mathrm{SiO}_{2}, \mathrm{Ca}, \mathrm{Mg}, \mathrm{Na}, \mathrm{Fe}$, $\mathrm{Al}, \mathrm{Mn}, \mathrm{Cu}$ (ether soluble), detergents, turbidity, conductivity, $\mathrm{pH}$, Rhyznar Index; dissolved oxygen, and BOD. In addition to water chemistry parameters, current velocities were measured with a Gurley current meter.

In 1969, only four stations were sampled for water chemistry. These corresponded with temperature and macroinvertebrate stations shown in Table 5. Approximately bimonthly analys is included alkalinity, BOD, phosphates and total, inorganic and organic solids. At the plant site the same 36 parameters were measured as in 1968 and at the same frequency. Water velocities and depth measurements were also taken concurrently with the macroinvertebrate sampling.

For the first half of 1970, sampling design and methodologies were the same as in 1969 for all physical parameters measured. However on 18 August 1970, all samples at the four stations were analyzed with a Hach water analys is kit.

During 1971, the first operational year for Monticel10, the water chemistry monitoring procedures were the same as those used in the latter half of 1970, including the same stations, sampling frequencies and analytical methods. Water velocity and depth measurements were again taken in conjunction with the macroinvertebrate program. Thirty-six parameters were measured only during February, April, November, and December, at the plant site. The same parameters were measured approximately $0.2 \mathrm{~km}$ above the intake and below the discharge canal in November and December. 
TABLE 5. Water Quality Monitoring Stations

\begin{tabular}{|c|c|c|}
\hline $\begin{array}{l}\text { Temperature } \\
\text { Station } \\
\end{array}$ & $\begin{array}{l}\text { Used for Measuring } \\
\text { Other Parameters }\end{array}$ & Location* \\
\hline & Invertebrate $\mathrm{Cl}$-control & $\begin{array}{l}\sim 5,500 \mathrm{ft}(1676 \mathrm{~m}) \\
\text { upstream }\end{array}$ \\
\hline 1-control & & $\begin{array}{l}\text { य3,600 ft }(1097 \mathrm{~m}) \\
\text { upstream }\end{array}$ \\
\hline 2-control & $\begin{array}{l}\text { Water chemistry } 1 \text {-control } \\
\text { Invertebrate } \mathrm{C} 2 \text {-control }\end{array}$ & $\begin{array}{l}\sim 2,700 \mathrm{ft}(823 \mathrm{~m}) \\
\text { upstream }\end{array}$ \\
\hline 3 & $\begin{array}{l}\text { Water chemistry-2 } \\
\text { Invertebrate E-1 }\end{array}$ & Near discharge \\
\hline 4 & Invertebrate $E-2$ & $\begin{array}{l}\text { 1,500 ft }(457 \mathrm{~m}) \\
\text { downstream }\end{array}$ \\
\hline 5 & Invertebrate $\mathrm{E}-3$ & $\begin{array}{l}\sim 3,600 \mathrm{ft}(1097 \mathrm{~m}) \\
\text { downstream, above } \\
\text { rapids }\end{array}$ \\
\hline \multirow[t]{2}{*}{6} & Invertebrate $E-4$ & $\begin{array}{l}\text { } 6,500 \mathrm{ft}(1981 \mathrm{~m}) \\
\text { downstream }\end{array}$ \\
\hline & Invertebrate $E-5$ & $\begin{array}{l}\text { 28,100 ft }(2469 \mathrm{~m}) \\
\text { downs tream }\end{array}$ \\
\hline 7 & Water chemistry-3 & $\begin{array}{l}\text { च 10,400 ft }(3170 \mathrm{~m}) \\
\text { downstream }\end{array}$ \\
\hline 8 & & $\begin{array}{l}\text { 213,500 ft }(4115 \mathrm{~m}) \\
\text { downs tream }\end{array}$ \\
\hline 9 & $\begin{array}{l}\text { Water chemistry-4 } \\
\text { Invertebrate E-6 }\end{array}$ & $\begin{array}{l}\text { 17,700 ft }(5395 \mathrm{~m}) \\
\text { downstream }\end{array}$ \\
\hline
\end{tabular}

*Distance from discharge canal.

In 1972, water chemistry data were collected and analyzed the same way as in 1971 except Station 4 was dropped and only three stations were sampled. Water velocities and depth measurement were determined concurrently with the macroinvertebrate program as in previous years. Monthly measurements were made $0.2 \mathrm{~km}$ above plant intake, $0.2 \mathrm{~km}$ below the discharge canal, and a station was added in the discharge canal. Water chemistry methods for 1973 and 1974 were the same as those used in 1971 and 1972. 


\section{PREDICTION OF THE THERMAL REGIMES}

An effort was made by NSP to mathematically model the thermal discharges to the river and predict surface isotherms downstream from the discharge. Several different heat dissipation operating modes, climatic, and river discharge conditions were modeled. The model employed in the simulations was a combination of the phenomenological correlations of Asbury and Frigo (1971), and observed thermal plume data obtained after operation began. The situation for prediction of the thermal regimes was unusual because the plant had a]ready begun operation when the analysis was performed and some field isotherms had been defined.

The Asbury-Frigo (1971) treatment yields isotherm surface areas and enables one to employ previously obtained field data to tune the predicted isotherm areas to that field data. The great disadvantage is that the correlations by Asbury and Frigo are for surface discharges into the Great Lakes and their work was a simplification of the earlier work by Edinger and Polk (1969). Thus, the Asbury and Frigo (1971) approach is a poor one to use to predict the characteristics of the Monticello discharge plume. Since the methods of Edinger and Polk (1969) are also applicable to riverine environments, better agreement would probably be obtained by using their methods; certainly this is true once a small amount of field data became available. Another model available at the time of the analysis which might have been better to use was that of Koh and Fan (1970). Although the Koh and Fan model does not allow the inclusion of field data to as great a degree as either of the others, it is reasonably rigorous and would probabiy have predicted the discharge more accurately than the others, particularly for conditions different from those for which field data was available. The thermal surveys discussed earlier in this section were intended to offer verification for these modeling efforts. The comparison of the predicted cases and the thermal surveys are discussed further in Section VII. 
v. ECOLOGICAL MONITORING 



\section{ECOLOGICAL MONITORING}

\section{PREOPERATIONAL AQUATIC ECOLOGY MONITORING}

\section{PERIPHYTON (1968-1970)}

Due to the high current velocity in the Mississippi River near the site, true plankton, both phytoplankton and zooplankton, are absent and are so sparse that they do not contribute significantly to the aquatic ecosystem. The attached algae (periphyton) at the site are the important sources of primary production in the river and therefore, were chosen to be monitored for detection of potential power plant impacts.

The study began in May 1968, with 13 stations chosen as sampling sites (Figure 6). Stations 1 and 2 are upstream of the plant while Stations 3, 4, and 5 form a transect across the river near the end of the discharge canal. Stations 6,7 , and 8 form a transect about $1 / 4 \mathrm{mile}(0.4 \mathrm{~km})$ below the discharge canal with Stations 9 and 10 about another $1 / 2 \mathrm{mile}(0.8 \mathrm{~km})$ downstream near the lower end of an oxbow in the river. Stations 11,12 , and 13 are located $2-1 / 2$ miles $(4 \mathrm{~km}), 3-1 / 2$ miles $(5.6 \mathrm{~km})$ and $5-1 / 2$ miles $(8.8 \mathrm{~km})$ downstream from the discharge canal, respectively.

During 1968, very little sampling was accomplished because the sampling equipment initially used was not suitable for the fast-moving water near the site area and the abnormally high water runoff in 1968 also made sampling difficult. Periphyton were collected on artificial substrates (glass slides). Nine glass slides were placed in a holder and periphyton were allowed to colonize for approximately 2 weeks before it was removed for analysis. This method is uniform, nonselective, quantifiable and is useful for comparison of periphyton among several locations (Hopwood, 1969). It was not intended, however, to duplicate periphyton communities attached to the natural river bottom substrates. Samples that were collected showed large variances among the 9 slides per sampler, due most likely to large pieces of debris that clogged the sampler. 


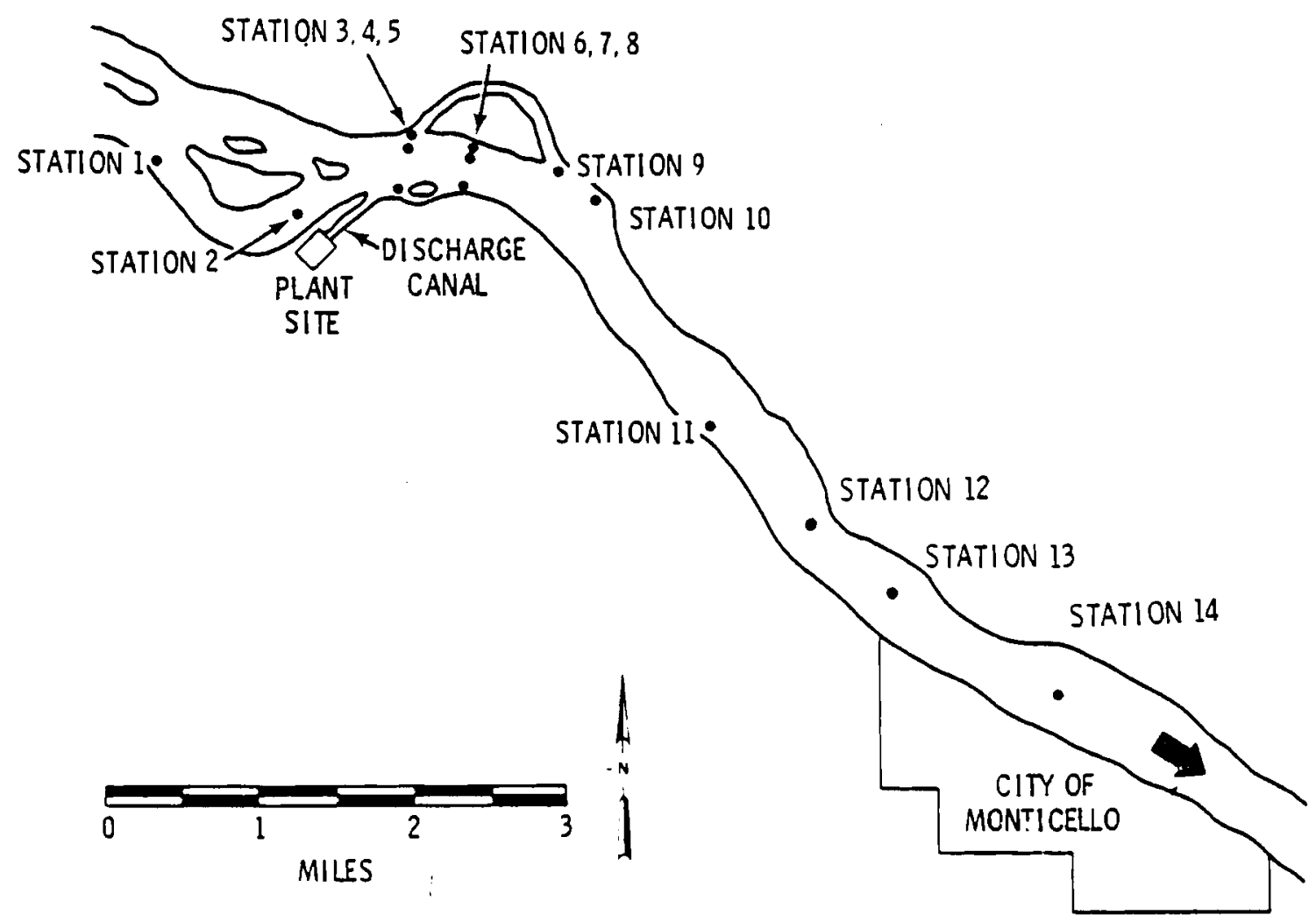

FIGURE 6. Position of Periphyton Artificial Substrates in 1968 and 1969

In 1969, sampler problems were largely overcome by adding a brushiike ring of stiff wires extending in front of the slide holders to entrap debris. Final design and testing began in April but it was not until July 9 that the program was in full operation. Due to human disturbances and high current flow, many samplers and slides were lost from July 9 through November 1969. The sampling stations remained as originally designed in 1968 with the exception of adding Station 14 (Figure 6 ), located just upstream from Highway \#25 bridge at Monticello (approximately $6 \mathrm{~km}$ below the plant). Periphyton measurements included counts of the individual numbers per square centimeter by species, dry weight biomass by the tared slide technique, and chlorophy11-a concentrations by the trichromatic technique (Standard Methods, 1960). 
Samples were collected in February, May, June, July, August, September, October, and November 1970; no collections were made in March, April, and December because the ice cover on the river made sample collection hazardous. Fourteen percent of the samples were lost during the year and cell counts were reported for only two time intervals. In addition to cell counts, and pigment and biomass analyses, the following additional analyses were performed: 1) chlorophyll-a and pheophytin-a measurements by the Lorenzen (1967) technique which differs from the previously used trichromatic technique; 2) biomass measurements were made by a modification of the Grzenda and Brehmer (1960) technique, and, 3) sample replication was increased from two to three. The sampling stations remained the same as in 1969. The 1971 periphyton sampling is considered operational monitoring and will be discussed later.

MACROINVERTEBRATES (1968-1970)

Since June 1968, two types of sampling techniques were employed. The first was a qualitative method that utilized hand netting and screening of bottom material among the grasses and sedges along the shoreline where the water was less than $2 \mathrm{ft}$ deep. Exact locations could not be determined for the hand-netted samples. The organisms that were collected were classified to the lowest taxonomic level. A second method was quantitative, employing a stream bottom sampler consisting of a collapsible wire mesh bag surrounded by a nylon organdy bag (Bull, 1968). Inside the bag, clean rocks (surface area $\sim 22.5 \mathrm{~m}^{2}$ ) were placed and allowed to colonize for 1 month. The bag was retrieved and the organisms separated from the rocks, identified, counted, and weighed. Samples were collected at seven stations (Figure 7).

In 1969 qualitative sampling was curtailed and a more intense quantitative study was initiated. The wire mesh, nylon bag sampler was replaced by a sampler more adaptable to water currents and depths near the site. The new artificial substrate sampler was designed by Brit.t (1955) and consisted of a concrete block with dimensions of $31.62 \mathrm{~cm} \times 31.62 \mathrm{~cm} \times 8.00 \mathrm{~cm}$. The exposed surface of the block was roughened by sand blasting to provide a better surface for organism attachment. The block weighed about $18 \mathrm{~kg}$ and was self-anchoring. After the 1 month colonization time, the samplers were 


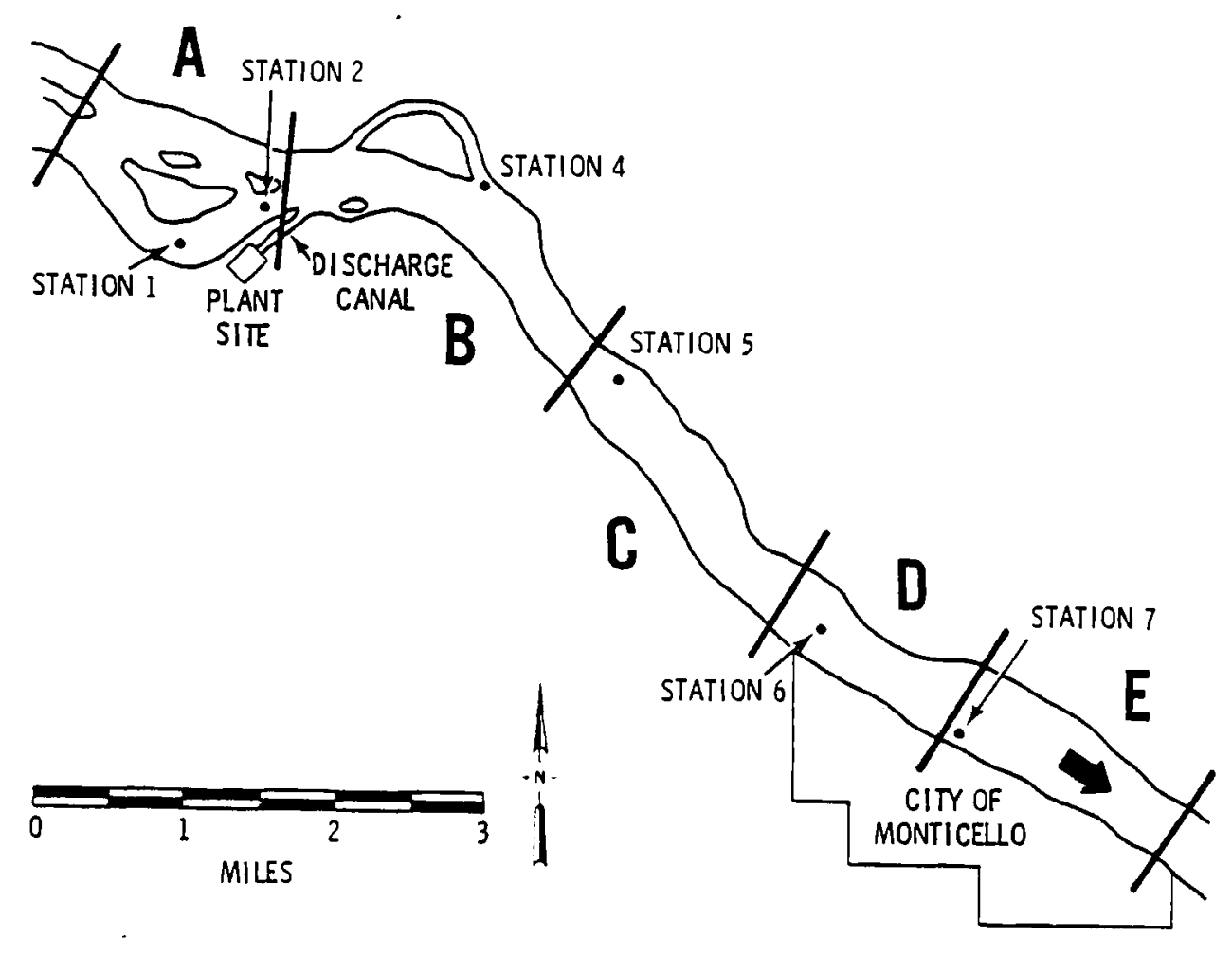

FIGURE 7. Position of Macroinvertebrate Bull Samplers in 1968 and Fish Electroshocking Sectors (A-E)

retrieved and the organisms were removed by hand, preserved in a $10 \%$ formal in solution and brought back to the laboratory for analyses. Organisms were classified, counted, and then wet and dry weight determinations were made for each taxonomic group on each block. The study used a total of 88 blocks with 4 blocks per station during all four seasons. Sampling locations also changed from that used in 1968 to include 8 transects across the river with 2 above the plant as controls and 6 below as experimental transects, and, each station on each transect used four blocks as depicted in Figure 8. In 1970, the last year of preoperational monitoring, the macroinvertebrate sampling employed the same methodologies, stations and frequencies utilized in 1969 quantitative macroinvertebrate monitoring. The qualitative near-shore sampling (hand netting) was discontinued. However, due to the low number of stoneflies (Plecoptera) collected on the cement blocks in 1969, these organisms were collected separately with a Surber net $\left(30.5 \mathrm{~cm}^{2}\right)$ at only 4 transects $(\mathrm{Cl}, \mathrm{C} 2, E 1$ and E4). Sample collection and processing was the same as with the concrete block samples. 


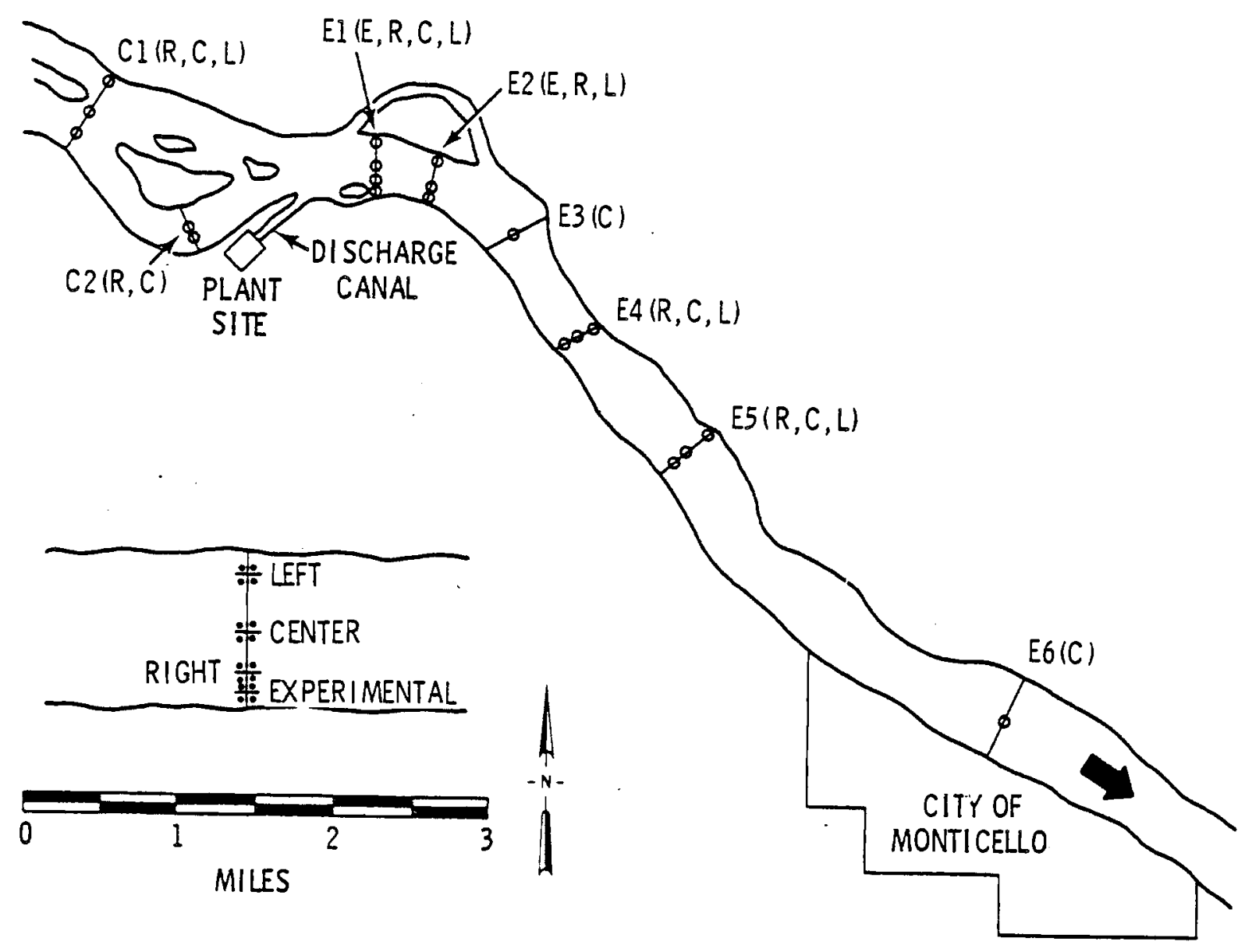

FIEURE 8. Position of Macroinvertebrate Concrete Block Samplers in 1969

\section{FISH (1968-1970)}

Fish studies were initiated in 1968 to determine the species composition and population density of the fish found in the vicinity of the site. Electrofishing was the primary tool used to collect fish in the river because stationary nets and traps could not be used in the swift currents. The electrofishing gear consisted of a 3,000 watt, 230 volt AC Homelite generator; control panel and switch box; a boom frame of galvanized steel tubing; and three electrodes hanging from the frame into the water off the bow of the boat. Fish were collected by orienting the boat parallel to the shore with the bow pointing downstream so that the shocked (stunned) fish would surface toward the bow for hand dip-netting. The dip-netted fish were placed in tujs of water and after completion of a shocking run, they were 
counted, measured, weighed, tagged with monofilament spaghetti tags and released. Scale samples were taken from each fish for age analysis. Electrofishing was conducted in five sectors $(A-E)$ of the river (Figure 7 ) between predetermined landmarks.

The 1969 fish studies were essentially the same as in 1968 with electroshocking and tagging the principal field techniques used. It should be noted that the Schnabel Method was used to estimate population densities.

In 1970, seining replaced electrofishing as the method of fish collection. The seines were of a nonbag type, $20 \mathrm{ft}(6.1 \mathrm{~m})$ long, with either a $1 / 4(6.4 \mathrm{~mm})$ or $1 / 8 \mathrm{in} .(3.2 \mathrm{~mm})$ mesh. The seining stations were confined along the shoreline in areas of shallow slow moving water. Average current velocities about $1 \mathrm{fps}(.3 \mathrm{~m} / \mathrm{sec})$ or less allowed operation of the seine from upstream to downstream direction. Six stations were established with two control stations located above the plant and four stations downstream of the plant (Figure 9). Seining was conducted 21 times between 26 May through 13 August 1970. Fish were classified and counted; however, if more than 100 fish were captured per haul, only an aliquot of 100 was counted and the rest returned immediately to the river. 


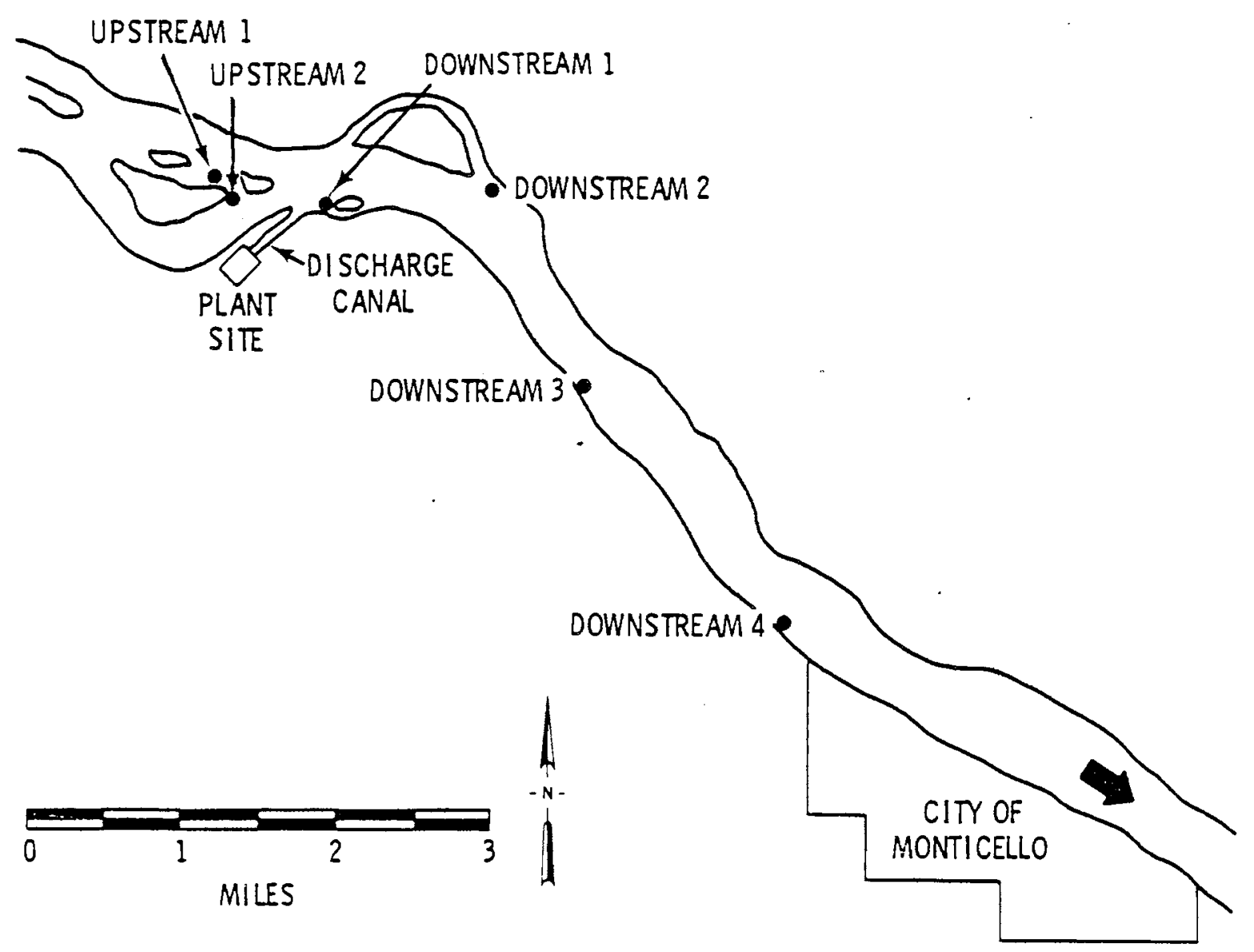

FIGURE 9. Fish Seining Stations 1970-1971 


\section{OPERATIONAL AQUATIC ECOLOGY MONITORING}

\section{PERIPHYTON (1971-1974)}

Operational monitoring began in 1971. Sampling techniques were the same as those used for preoperational periphyton monitoring. Three new stations were added; Station 3A, located in the discharge canal upstream from Station 3, and Station $4 \mathrm{~A}$, another control station located on the opposite side of the river from the discharge canal upstream from Station 4 (Figure 10). Station 14, which was located just upstream from Highway Bridge \#25 in the town of Montice110, was deleted to reduce the number of analyses. A single winter sample was collected beneath the ice at 12 stations during February and March; during warmer months from 13 May to 18 October all stations were monitored biweekly.

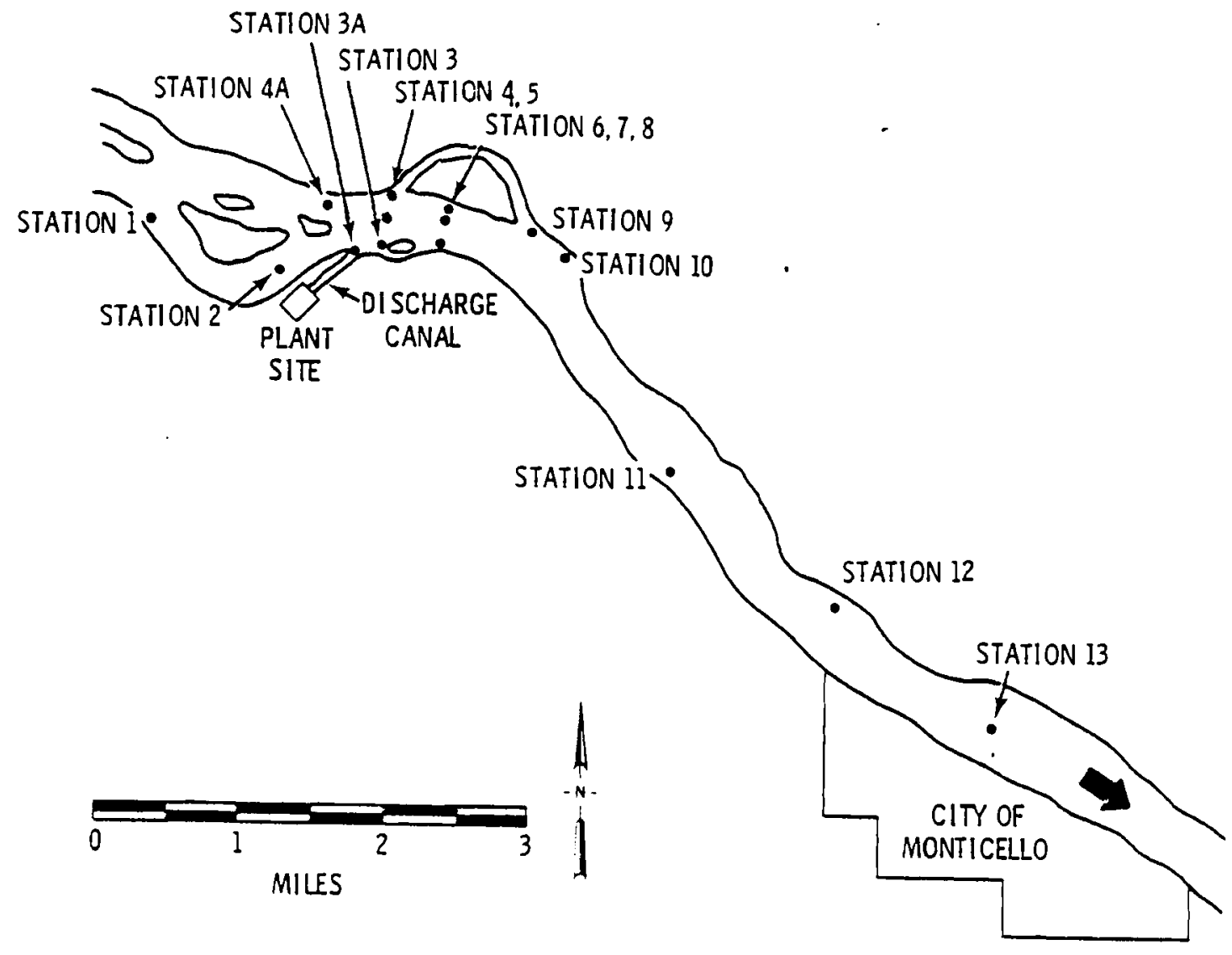

FIGURE 10. Position of Periphyton Artificial Substrate Collectors - 1971 
During 1972, the sampling techniques were identical to those used in 1971. Samplers underneath the ice were colonized for one month from 19 February to 16 March, biweekly during the warmer period from May through November. Station 13 was deleted because the data duplicated those of other stations.

In 1973, the third year of operational monitoring, sampling techniques were generally the same as those of previous years. However in 1973, no samplers were suspended beneath the ice in February because previous years' results showed essentially no growth beneath the ice. From 5 April to 23 November, floating open water samplers were exposed to biweekly colonization. Stations $1,4,5,8,10$, and 12 were deleted due to duplication of other stations leaving only Stations $2,3 A, 3,6,7,9$, and 11 .

Monitoring in 1974 included the same techniques and stations used in 1973. Sampling occurred only from 9 May to 3 November on a biweekly colonization schedule.

MACROINVERTEBRATES (1971-1974)

In 1971, two separate benthic monitoring studies were conducted. One was a continuation of the program conducted during 1969 and 1970, with methodologies and stations the same as in 1969 and 1970. The second study, initiated in July 1971, also used concrete cement blocks as artificial substrates but employed more of them at each station with the number of stations reduced to two (Figure 11). At each of the two stations, one above the plant (control) and one at the end of the discharge canal in the river proper (experimenta 1), five sets of four blocks (20 blocks) each were set on the river bottom. After allowing the blocks to colonize for 1 week one set of four blocks was removed from each station and analyzed as in the other study. Each week, for five consecutive weeks, one set of four blocks was removed and not replaced until the end of five weeks when a 11 blocks were replaced with new ones. This study was conducted between 19 July to 24 November 1971 to determine the growth and colonization rate of benthic organisms above and below the point of effluent discharge. 


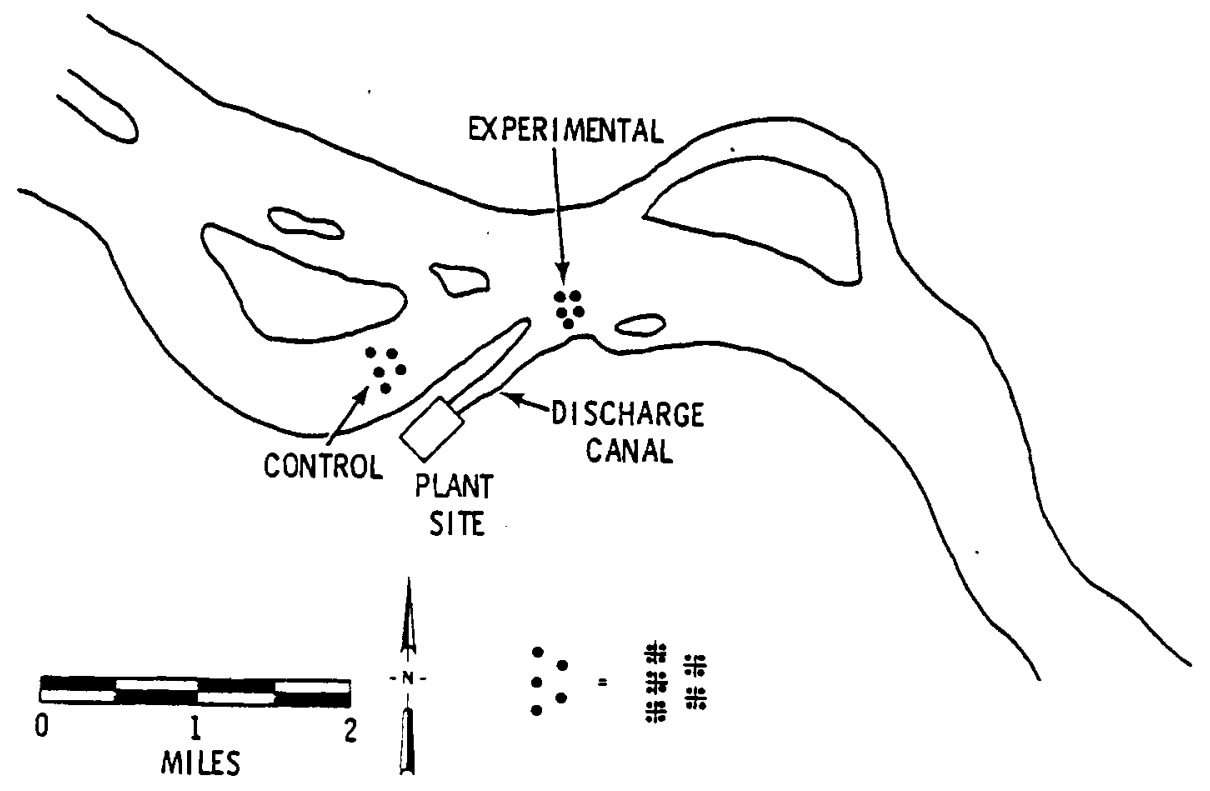

FIGURE 11. Position of Control and Experimental Stations for Benthic Colonization Study During 1971-1972

During 1972, benthic macroinvertebrate monitoring continued with the same two programs. The first, involving monthly colonization, was the same as in 1969, 1970, and 1971, and the same methodologies and techniques were employed. However, sampling transects were reduced to just one above the plant and four below (Figure 12); whereas in previous years there were two above and six below. The second study was concluded on 21 July 1972, after eight cycles of five weeks each were completed. Table 6 lists the eight sampling cycles and the substrate placement and recovery dates.

One benthic macroinvertebrate monitoring program was continued in 1973 and two new ones were initiated. Monthly samples were again collected, but at only three transects (C2, E1 and E2, Figure 12); in previous years up to eight transects were employed. Methodologies did not differ from the previous year. 


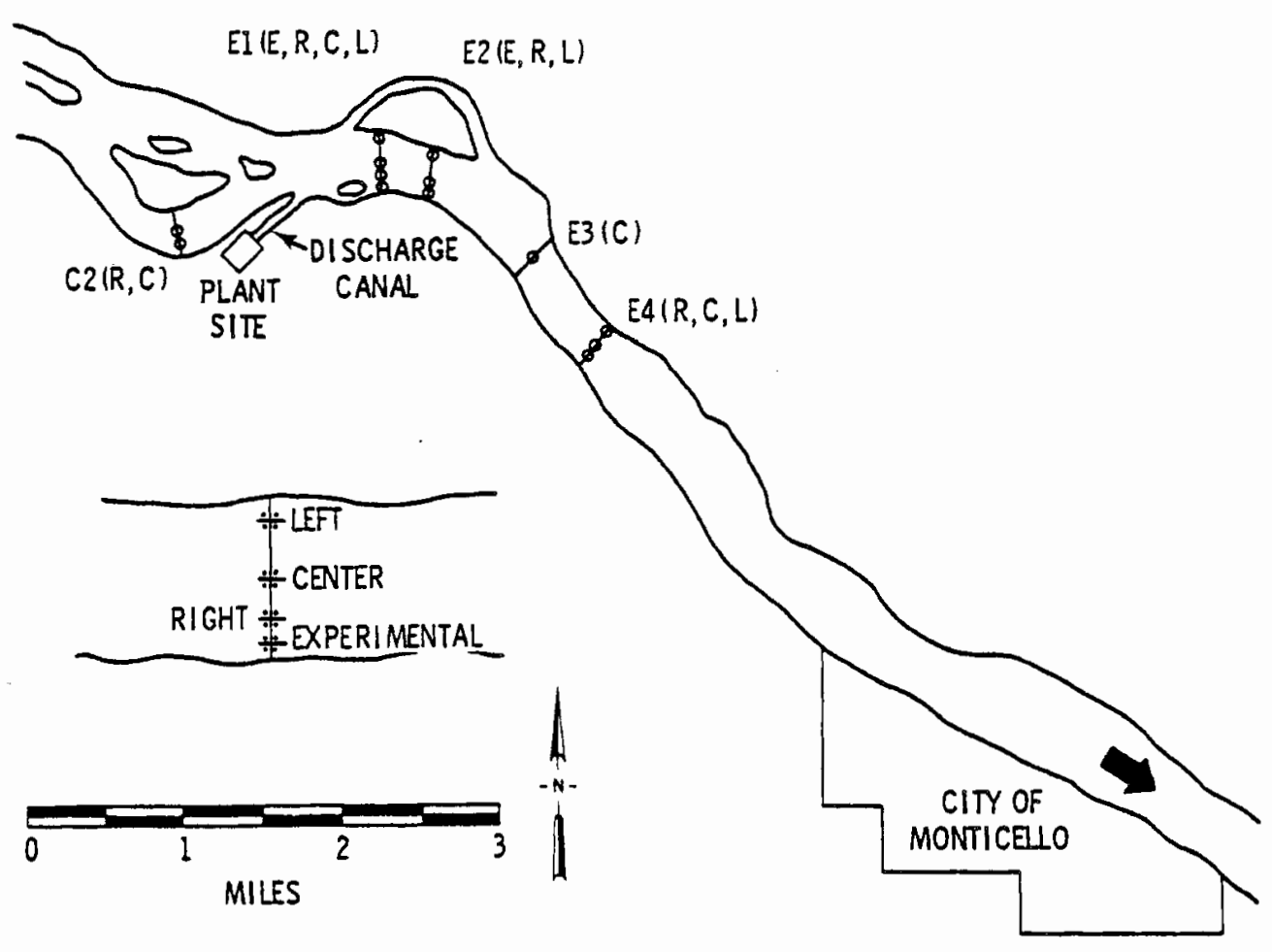

FIGURE 12. Position of Macroinvertebrate Concrete Block Samplers in 1972

TABLE 6. A List of Macroinvertebrate Sampling Cycles and Substrate Placement and Recovery

Cycle Dates

112 July - 16 August 1971

29 August - 13 September 1971

36 September - 14 October 1971

46 October - 10 November 1971 (Site E - 3 samples collected)

6 October - 27 October

52 November - 23 November 1971 (Site C only, 3 samples)

$6 \quad 15$ April - 19 May 1972 (Site E - collections on 29 April, 5 and 12 May)

719 May - 23 June 1972

823 June - 21 JuTy 1972 (4 samples 1-4) 
In July 1973, a 2-year study was begun to examine possible premature emergence and altered reproductive periodicity in aquatic insects exposed to heated plant effluents. Three stations were established on land about $2 \mathrm{~m}$ from the rivershore; one about a $1 / 2 \mathrm{~km}$ above the plant, the second by the discharge canal, and the last about $1 / 2 \mathrm{~km}$ below the discharge (Figure 13). Adult insects were collected nightly in a light trap consisting of a catch pan containing 50\% isopropanol, 117 uminated with a 15 watt fluorescent lamp and supported on a wooden stand. Each sample was counted and weighed.

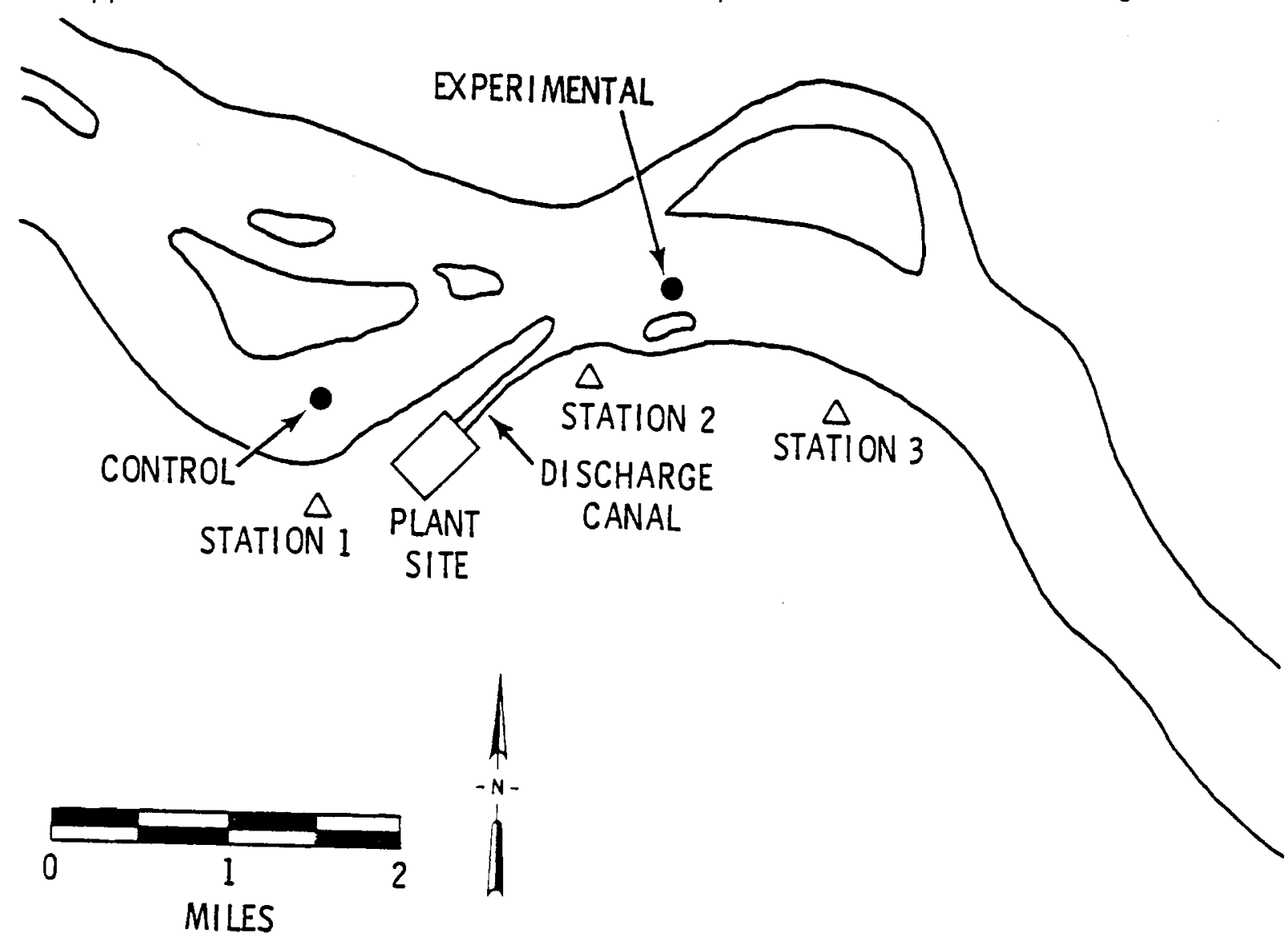

FIGURE 13. Position of Drift Insect Nets $(\bullet)$ and Insect Light Traps $(\Delta)$ in 1973-1974

The other new monitoring program, initiated in late July 1973, dealt with invertebrate drift organisms. Two stations were established and designated control and experimental (Figure 13). Samples were collected biweekly for 1 year with drift capture nets, $145 \mathrm{~cm}$ in length, with $15 \mathrm{~cm}$ square throats, constructed of 1/2-mm mesh netting. These nets were arranged 
in a vertical array extending from the river bottom to the river surface, with the top net only half submerged in the water. Collected organisms were classified, counted, and weighed.

The studies conducted in 1973 were continued in 1974 with methodologies and techniques remaining the same. The concrete block artificial substrate samples were collected monthly throughout the entire year. However, three new stations were added in December of 1973 ( $E_{E} I, C_{E} I$ and $C_{2} I$, Figure 14). The insect trapping study was completed in July 1974 with methodologies and techniques identical to those used in 1973. The invertebrate drift study provided the basis for a masters thesis by Matter (1975), entitled "Invertebrate Drift in the Mississippi River Near Montice110, Minnesota." The technique and methodologies were the same as in the previous year (1973).

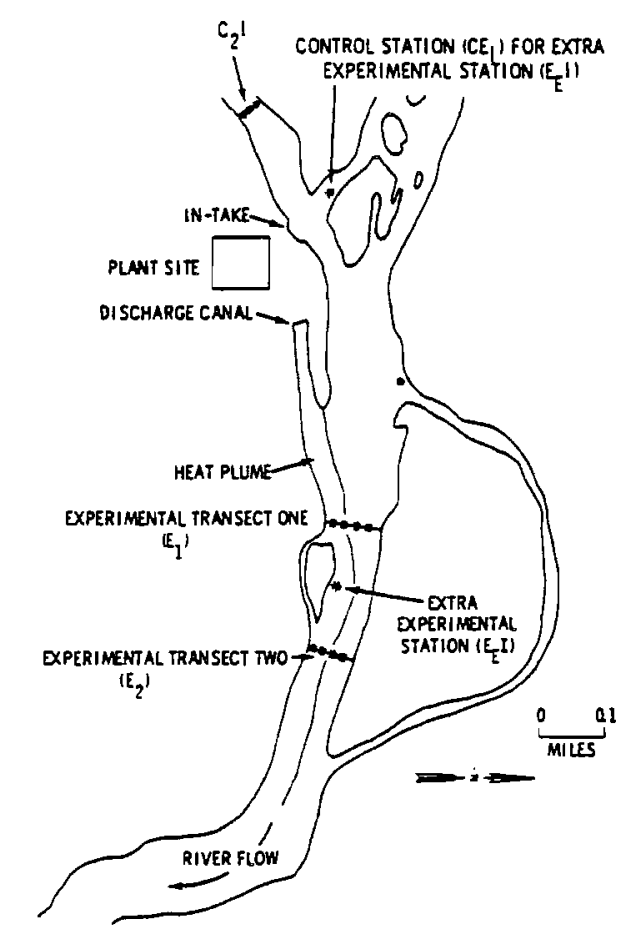

FIGURE 14. Position of Macroinvertebrate Concrete Block Samplers in 1974 
During 1971, the first operational year of fish studies, electrofishing methods, techniques and stations were the same as in the preoperational years (1968-1969). No seining was conducted in 1971 .

In 1972, fish studies included electrofishing, seining and a creel survey. Electrofishing locations during 1972 were the same as in previous years with the exception of the discharge canal, which was sampled separately from Sector B (Figure 7). The seining study of 1970 was continued using the same methods. However, after capture the minnows were marked with a powdered nontoxic textile dye and released. The dye was applied with a 100 psi air compressor paint spray unit. Approximately 1 hour after the dyed (tagged) fish were released, the area was reseined, and the marked fish were identified in a light-tight box illuminated by a 40 watt ultraviolet light. A population estimate was then made using this data. This study differed slightly from the preoperational seining study in that eight stations were sampled instead of six. The two additional stations were located above the.plant as extra controls. The third study conducted in 1972 was a stratified-random creel survey (Neuhold and Lu, 1957). This survey consisted of an instantaneous fish count and angler interviews. This method provides an unbiased estimate of the angler population and a qualitative procedure to estimate plant affects on sport fishing.

During 1973, the same three fish studies (electrofishing, seining, creel census) were continued. The electrofishing study was essentially the same except more emphasis was placed on delineating spawning areas in the vicinity of the plant by observing sex and breeding condition of the shocked fish. Electroshocking was conducted on 52 days between 26 March and 27 December 1973. The seining study was completed in 1973 and covered 1 year of plant operation (19 June 1972 to 25 July 1973). Methods and techniques employed were the same as those of 1972 and the creel census was identical to that carried out in 1972.

Fish sampling in 1974 included creel census, fish spawning, young-ofthe-year seining, fish impingement, and cold shock studies. Also included 
was a fish entrainment monitoring study. The creel census was the same as that conducted during the previous 2 years (a stratified-random creel survey). The fish spawning study (electrofishing) was essentially the same as that of 1973, except that sampling was conducted at weekly intervals from 6 April to 14 August 1974 in the section of river from $2 \mathrm{~km}$ upstream of the discharge to $10 \mathrm{~km}$ downstream of the city of Monticel10. A master thesis by Eberley (1975) "Spawning Activities of Major Fish Species in the Monticello Area of the Mississippi River, "evolved from the study. A new monitoring program initiated in 1973 and completed in 1974 investigated thermal influence on young-of-the-year fish (YOY). Previously employed seining techniques were used to make weekly collections of YOY from from mid-June through September for both years at four stations within each of three areas (Figure 15). The four stations represented two pool and two riffle habitats. The three areas included Section 1 above the plant, Section 2 below the plant on the opposite shore (out of influence of thermal plume) and Section 3 below the plant within the influence of the thermal plume.

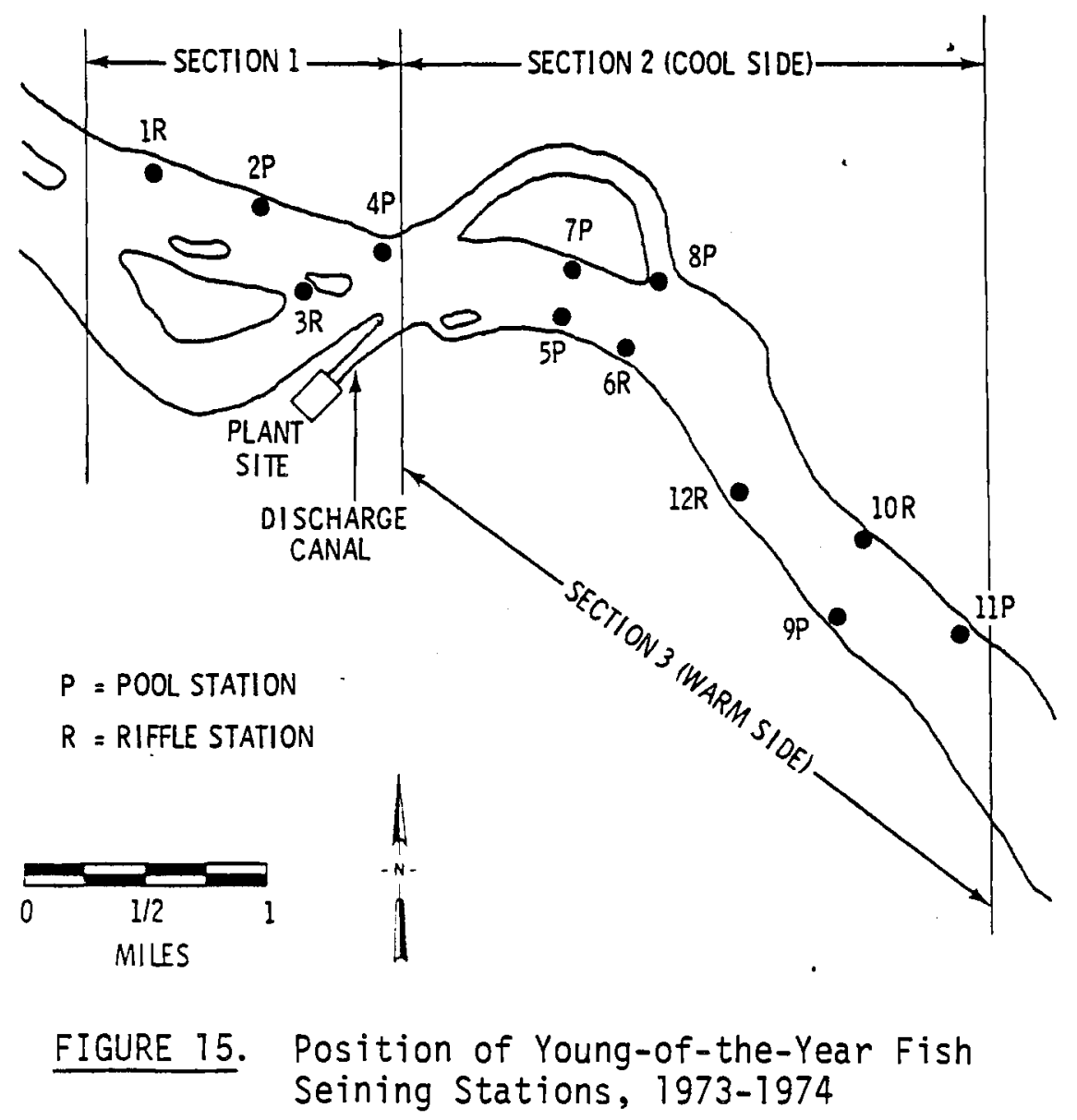


Fish impingement was measured 33 times between 11 JuTy 1973, and 26 December 1974, at approximately 2-week intervals. Samples were collected in a framed net placed inside the sluice canal (Figure 16) for the entire screen rinse period. Screen wash is diverted from screens though a canal to the river downstream from the cooling water intake. Screens are washed approximately every 8 hours or more frequently if needed. Fish collected from the sluice canal were placed in a holding tank for 10 min to examine their physical conditions. Mortalities were described in terms of loss of equilibrium and weak or intermittent opercular movement.

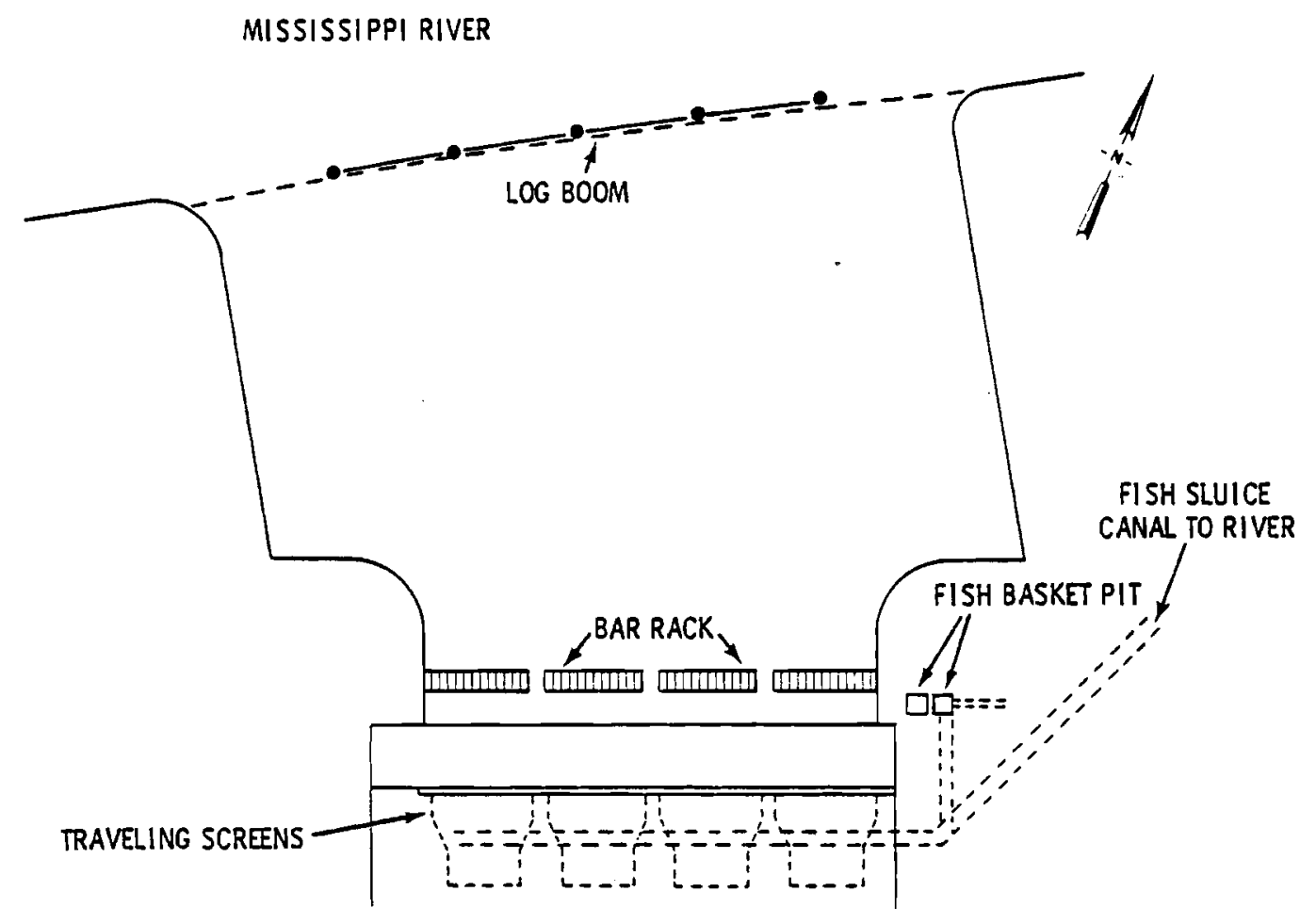

FIGURE 16. Diagram of Intake Structure and Sluice Canal for Impingement Canal 
A series of experiments were performed between 12 March to 18 March 1974, to determine the effects of winter plant shutdown (cold shock) on fish in the discharge canal. Six indigenous species including rock bass, walleye, black crappie, smallmouth bass and yellow and brown bullhead were tested. Duplicate tests were conducted. Fish were collected from the discharge canal 1 day prior to testing. If possible, all fish species were represented in the $0.9 \times 1.2 \times 1.2 \mathrm{~m}$ cages. At the rate of $5^{\circ} \mathrm{F}\left(2.8^{\circ} \mathrm{C}\right)$ every $12 \mathrm{~min}$, the fish were subjected to an overall temperature decrease of $25^{\circ} \mathrm{F}\left(13.9^{\circ} \mathrm{C}\right)$, from $60^{\circ} \mathrm{F}\left(15.5^{\circ} \mathrm{C}\right)$ to $35^{\circ} \mathrm{F}\left(1.7^{\circ} \mathrm{C}\right)$, in 1 hour. In the final 2 min of each test, opercular dilations were counted and recorded along with general conditions of the fish. Fish were observed at 2, 12, 24, 36, and 48 min and $1,2,5$, and 24 hours after reaching ambient temperature.

\section{Entrainment Studies}

Both laboratory and field fish entrainment studies were begun in 1972 under temperature conditions simulating those of passage through the plant cooling system. Test fish were the fathead minnow (Pimephales promelas), ranging between 30-60 mm in length. This fish is not indigenous to the Mississippi River near the Monticello Power Plant and was purposely chosen so there would be no problem in identifying the test fish. In the laboratory, oxygen consumption and response to thermal change was measured on animals acclimated to a wide range of temperature. Oxygen consumption was measured in fish acclimated to $1,5,10,15,20,25$ and $30^{\circ} \mathrm{C}$, and compared to the consumption rate of fish acclimated to $1,5,10$ and $15^{\circ} \mathrm{C}$ immediately after they had experienced a temperature increase of $15^{\circ} \mathrm{C}$. In the temperature tests fish were exposed for $15 \mathrm{sec}$ to a $\Delta T$ of $7.2^{\circ} \mathrm{C}$, then for $74 \mathrm{sec}$ at a $\Delta \mathrm{T}$ of $15^{\circ} \mathrm{C}$, and finally to a temperature decrease to river ambient over the next 10-15 min. These temperature changes represented those experienced by an entrained fish passing though the first condenser, second condenser, and discharge canal and mixing zone, respectively. After testing, fish were held at their original acclimation temperature for a 7-day observation period. 
The field studies were conducted in June, September, November, December of 1972, and February 1973. Fathead minnows were introduced to the intake water between the circulating water pumps and the traveling screens. Fish were recaptured in the discharge canal by seining and dip netting from boats and shore. The recaptured fish were then held in live boxes at river ambient temperature for observation and examination.

In 1973, a fish entrainment study was begun to examine the number, kinds and seasonal occurrence of natural entrainment of fish and large invertebrates. The study began in September 1973, and continued through August 1974 and was designed to assess incidence, not survivorship. Biweekly samples were collected by a fish collection device (Figure 17) consisting of a net of $6.4 \mathrm{~mm}$ hardware cloth mounted on a $2.4 \mathrm{~m}$ wide $0.34 \mathrm{~m}$ high and $0.41 \mathrm{~m}$ deep frame. This net was lowered into the discharge canal and filtered about $7-10 \%$ of the total discharged water. Ali sampling times included 6, $15 \mathrm{~min}$ to 3 hour samples over a 24-hour period. After collection, the contents of the net were removed, preserved, weighed, identified, and enumerated.

Terrestrial ecology operational monitoring programs were not conducted at Monticello Nuclear Generating Plant. No impacts on the terrestrial biota were expected from plant operation. 

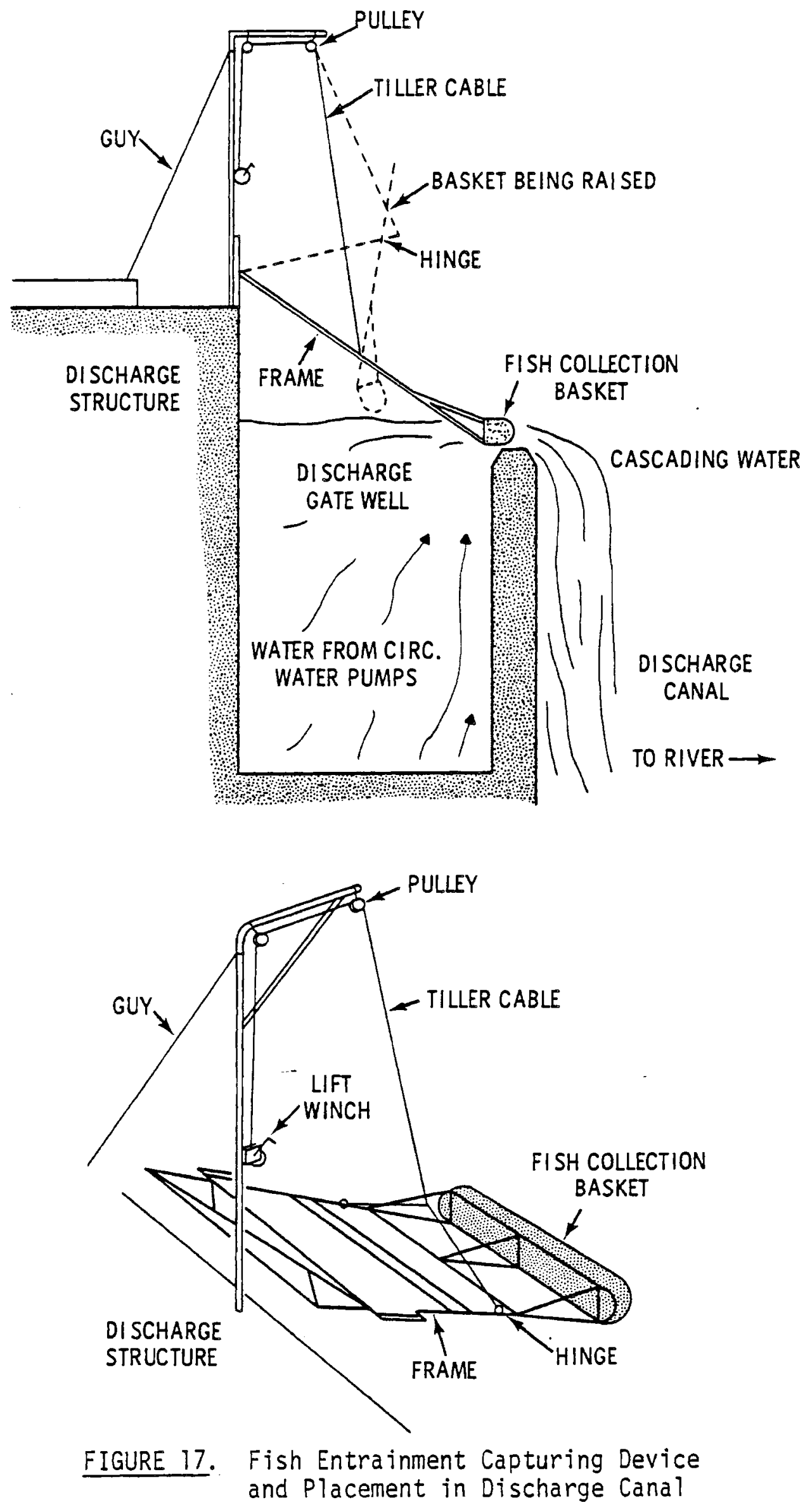


\section{RATIONALE FOR DATA SYNTHESIS}

Ecological monitoring programs have been conducted for approximately 8 years at Monticello. Some populations have been extensively monitored (from 1968-1974), thus data recording and synthesis for statistical analyses was a very important, and at times a cumbersome, aspect of this study. However, due to certain inconsistencies (e.g., additions and/or deletions of stations from year to year, changing sampling gear or methodologies, and reporting formats) not all data could be quantitatively evaluated (e.g., results section on fish). Thus, we present here the rationale for the choices we made whereby selected data sets were used for subsequent statistical analysis.

\section{PERIPHYTON}

Periphyton sampling was initiated in 1968 and has continued through 1975 (Table 7). During the first 2 years (1968 and 1969) sampling was conducted to improve and check sampling gear and field procedures. Limited results first appeared in the annual monitoring report in midyear 1969, but were reported in terms inconsistent with that of later reports. Therefore, only data from 1970 through 1974 were statistically and/or quantitatively analyzed by PNL. Thus, the results for 1 year of preoperation and 4 years of operation were available.

Since our analysis scheme required that samples be collected from the same stations in each collection period we deleted results from those stations which did not meet this criterion. For example, in 1968 thirteen stations were used as sampling sites, in 1969 one was added, in 1971 two new stations were added and one deleted, in 1972 three stations were deleted, and 1973-1974 only seven stations were monitored. Therefore, our final analyses incorporated data from these seven stations $(2,3,3 \mathrm{~A}, 6,7,9$, and 11), (Figure 10) chosen because they were consistent throughout the sampling period 1970-1974.

Both temperature and current measurements made at these stations allowed us to analyze productivity based on concurrent values of these parameters. Stations 6 and 9,2 and 11 , and 3 and 7 were paired on the basis of slow, 
TABLE 7. Summary of Periphyton Sampling and Analytical Methods

\begin{tabular}{|c|c|c|c|c|c|}
\hline YEAR & COLLECTION METHOD & SAMPLING FREQUENCY & STATION LOCATION(S) AND NUMBER(S) & ANALYSIS & REMARKS \\
\hline \multicolumn{6}{|c|}{ PREOPERATIONAL } \\
\hline 1968 & $\begin{array}{l}\text { ARTIFICIAL SUBSIRATES } \\
\text { GLASS SLIDES }\end{array}$ & $\begin{array}{l}\text { INCONSISIENT, WAS } \\
\text { DESIGNED FOR BIWEEKLY } \\
\text { COLLECTIONS }\end{array}$ & $\begin{array}{l}2 \text { UPSIREAM ICONIROLSI } \\
3 \text { - JUST BELOW DISCHARGE } \\
3 \text { - 1/4 MILE BELOW DISCHARGE } \\
2 \text { - IR MILE BELOW DISCHARGE } \\
1 \text { - } 21 / 2 \text { MILE BELOW DISCHARGE } \\
1 \text { - } 31 / 2 \text { MILE BELOW DISCHARGE } \\
1 \text { - } 5 \text { I/2 MILE BELOW DISCHARGE }\end{array}$ & $\begin{array}{l}\text { CELL COUNTS EXPRESSED AS CELLS/ } / \mathrm{cm}^{2} \\
\text { PIGMENT ANALYSIS BY THE IRICHROMAIIC } \\
\text { TECHNIQUE FOR CHLOROPHYLL a b. C AND } \\
\text { CAROTENOIDS. DRY WEIGHT BIOMASS } \\
\text { EXPRESSED AS gmS / SLIDE }\end{array}$ & $\begin{array}{l}\text { THIS SAMPLING GEAR WAS BASICALYY } \\
\text { USED TO DEVELOP SAMPLING TECHNIQUES. } \\
\text { VERY LITILE DATA WERE COLLCTED }\end{array}$ \\
\hline 1969 & $\begin{array}{l}\text { ARTIFICIAL SUBSTRATES, } \\
\text { GLASS SLIDES }\end{array}$ & $\begin{array}{l}\text { INCONSISIENT FROM } \\
\text { APR TO } 9 \text { JUL. } 9 \text { JUL } \\
\text { THRU } 30 \text { OCT, BIWEEKLY }\end{array}$ & $\begin{array}{l}\text { SAME AS 198, EXCEPT ONE } \\
\text { STATION ADDED } 4 \text { MILES BELOW } \\
\text { DISCHARGE (14 TOTAL) }\end{array}$ & $\begin{array}{l}\text { SAME AS IN } 1968 \text { FOR CELL COUNTS AND } \\
\text { PIGMENT ANALYSIS. PRY WEIGHT BIOMASS } \\
\text { EXPRESSED AS mg/cm }\end{array}$ & $\begin{array}{l}\text { FINAI. DESIGN OF SAMPLING GEAR WAS } \\
\text { ACHIEVED BY ADDING A WIRE BRUSH } \\
\text { RING ON UPSTREAM SIDE OF SAMPLER } \\
\text { TO PREVENT DEBRIS CLOGGING }\end{array}$ \\
\hline 1970 & $\begin{array}{l}\text { ARIIFICIAL SUBSIRATES, } \\
\text { GLASS SLIDES }\end{array}$ & $\begin{array}{l}\text { ONE MONIHLY } \\
\text { INCUBATION IN MAR } \\
\text { UNDERNEATH ICE AND } \\
\text { BIWEEKLY FROM } 19 \text { MAY } \\
\text { THRU } 7 \text { NOV }\end{array}$ & SAME AS IN $1 \% 9$ & $\begin{array}{l}\text { CELL COUNTS SAME AS IN } 1969 \text {, CHLOROPHYLL } \\
\text { A AND PHEOPHYTIN a BY TRICHROMATIC AND } \\
\text { LORENZEN TECHNIQUES. DRY WEIGHT BIOMASS } \\
\text { SAME AS } 1 \% 9\end{array}$ & $\begin{array}{l}\text { LORENZEN TECHNIQUE INITIAIED BECAUSE IT } \\
\text { IS MORE ACCURAIE AND FASTER THAN THE } \\
\text { TRICHIROMAIIC TECHNIQUE. CELL COUNTS } \\
\text { ONLY REPORIED FOR TWO TIME PERIODS }\end{array}$ \\
\hline \multicolumn{6}{|c|}{ OPERATIONAL } \\
\hline 1911 & $\begin{array}{l}\text { ARTIFICIAL SUBSTRATES, } \\
\text { GLASS SLI DES }\end{array}$ & $\begin{array}{l}\text { MONTHLY IN FEB AND } \\
\text { MAR UNDER ICE AND } \\
\text { BIWEEKLY FROM } 13 \text { MAY } \\
\text { THRU } 28 \text { OCT }\end{array}$ & $\begin{array}{l}\text { 13 STATIONS REMAINED THE } \\
\text { SAME, DEIFTED ONE STATION } \\
\text { BY HIWAY R25 BRIDGE AND } \\
\text { ADDED } 2 \text { SIATIONS (ONE IN } \\
\text { DISCHARGE CANAL AND ONE } \\
\text { ACROSS RIVER FROM IT) }\end{array}$ & $\begin{array}{l}\text { CELL COUNIS AND DRY WEIGHT BIOMASS SAME } \\
\text { AS IN } 1970 \text {. CHLOROPHYLL a AND PHEOPHYTIN a } \\
\text { BY THE LORENZEN TECHNIQUE ONLY }\end{array}$ & $\begin{array}{l}\text { FIRST YEAR OF OPERATIONAL MONITORING. } \\
\text { DROPPED THE IRICHROMATIC TECHNIQUE } \\
\text { FOR PIGMENT ANALYYSIS }\end{array}$ \\
\hline 1972 & $\begin{array}{l}\text { ARTIFICIAL SUBSTRATES, } \\
\text { GLASS SLIDES }\end{array}$ & $\begin{array}{l}\text { MONTHLY IN FEB AND } \\
\text { MAR UNDER THE ICE } \\
\text { BIWEEKLY FROM MAY } \\
\text { THRU NOV }\end{array}$ & $\begin{array}{l}\text { THE } 3 \text { FURTHEST DOWNSTREAM } \\
\text { STATIONS DELEIED (12 TOTAL } \\
\text { STATIONS) }\end{array}$ & $\begin{array}{l}\text { SAME AS IN } 1971 \text { EXCEPI ONLY CHLOROPHYLL a } \\
\text { WAS ANALYZED FOR PIGMENT ANALYSIS }\end{array}$ & $\begin{array}{l}\text { MADE RECOMMENDATIONS THAT DATA } \\
\text { NEED NOT BE DUPLICAIED AND SET } \\
\text { GUIDELINES FOR STATISTICAL ANALYSES } \\
\text { ON A REDUCED SCHEDULE }\end{array}$ \\
\hline 1973 & $\begin{array}{l}\text { ARIIFICIAL SUBSIRAIES, } \\
\text { GLASS SLIDES }\end{array}$ & $\begin{array}{l}\text { BIWEEKLY FROM } 5 \text { APR } \\
\text { THRU } 3 \text { NOV }\end{array}$ & $\begin{array}{l}\text { REDUCED NUMBER OF STATIONS } \\
\text { TO 7: ONE UPS IREAM CONTROL. } \\
\text { ONE IN DISCHARGE. AND FIVE } \\
\text { BELON DISCHARGE }\end{array}$ & SAME AS IN 1972 & $\begin{array}{l}\text { NO WINTER SAMPLING BENEATH THE ICE } \\
\text { BECAUSE PREVIOUS STUDIES SHOWED } \\
\text { ESSENTIAILY NO GROWTH OR } \\
\text { COLONIZATION }\end{array}$ \\
\hline 1974 & $\begin{array}{l}\text { ARTIFICIAL SUBSTRATES, } \\
\text { GLASS SLIDES }\end{array}$ & $\begin{array}{l}\text { BIWEEKLY FROM } 9 \text { MAY } \\
\text { THRU } 3 \text { NOV }\end{array}$ & SAME AS IN 1973 & SAME AS IN 1973 & $\begin{array}{l}\text { PERFORMED SIATISTICAL ANALYSES ON } \\
\text { THE DATA }\end{array}$ \\
\hline
\end{tabular}


medium, and fast currents, respectively. In addition, a thermal comparison was made since Stations 2, 7 , and 9 were in water unaffected by the therma 1 plume while Stations 3,6 , and 11 were always in the plume (when the plant was operational).

\section{BENTHIC MACROINVERTEBRATES}

Benthic macroinvertebrates were sampled by NSP from 1968 through 1974 (Table 8) but we only evaluated data collected between 1969 through 1972 (two preoperational and two operational years). Usable data was obtained from annual monitoring reports, personal communication with NSP and their consultants, and a graduate dissertation. Data collected during 1968 were not used because sampling gear differed from that used in 1969-1974. In addition, data (percentages) reported in the 1973 and 1974 Annual Reports were inconsistent with those of 1969-1972 (numbers per station).

Similar stations and/or transects were not always given in each year. However, four transects were consistent in the years defined above (1969 to 1974). These included $\mathrm{C} 1, \mathrm{C2}, \mathrm{El}$ and E2 even though up to eight transects were sampled at one time, or in one year.

In 1970, both a Surber net and concrete blocks were used because of the low numbers of stoneflies collected by the concrete blocks. We did not analyze this data because it was not consistent with the data reported from the other years.

Three other short-term ( 1 year) studies were not examined. These studies included: 1) a recolonization study to assess the effect of heat on growth rates, 2) an invertebrate drift study to determine both drift composition and vertical distribution, and 3) flying insect collection to determine if thermal gradients influence emergence or seasonality of these insects.

Since each study lasted 1 year, their utility lies in a supportive role to the long-term macroinvertebrate monitoring program. For example, the weekly recolonization study verified that monthly collections (in the monitoring program) were adequate to determine benthic colonizations in terms 
TABLE 8. Summary of Macroinvertebrates Sampling and Analytical Methods

PREOPERATIONAL

1968

HAND-NETTING ALONG

SHORELINE

STREAM BOTTOM

SAMPLES (BULL (1\%B))

1969

CONCREIE BLOCXS HAVING DIMENSIONS OF

$31.6 \times 31.6 \times 8 \mathrm{~cm}$ WEIGHIN

$\sim 18 \mathrm{~kg}$ BRIT (1955)

1970

CONCREIE BLOCKS

SURBER NET

OPERATIONAL

1971

CONCREIE BLOCKS

CONCREIE BLOCKS

1972

CONCRETE BLOCKS

CONCREIE BLOCXS

1973

CONCRETE BLOCKS

LIGHT TRAPS

DRIFT CAPIURE NETS

CONCREIE BL.OCKS

LIGHI TRAPS AND DRIFT NEIS

SAMPLING FREQUENCY

NOT XNOWN

MONTHLY COLONIZATIONS

JUL THRU NOV

A

5 RIVER SECTORS, 1 ABOVE AND 4 BELOW

7 SIAIIONS - 2 ABOVE AS CONIROLS AND 5 DOWNS IREAM FROM DISCHARGE AREA TO HIWAY 125 BRIDGE

MONTHLY COLONIZATIONS IN FEB, MAY, JUN, JUL AUG, SEP. OCI AND NOV

8 IRANSECTS WITH 1 - 4 STATIONSI IRANSECI AND 4 SAMPLES/ SIATION: 2 IRANSECTS ABOVE PLANT AS CONIROLS AND 6 BELON

MONTHLY COLONIZATIONS SAME AS IN 1969

AS IN 1969

MONTHLY

SAME AS ABOVE EXCEPT 2 INTERMEDIATE DOWNSTREAM IRANSECIS DELETED

MONTHLY COLONIZATIONS SAME AS IN 1970

AS IN 1970

WEEKLY COLONIZATIONS

FROM 19 JUL THRU 24 NOV

2 SIATIONS - I CONIROL AND 1 EXPERIMENTAL. 5 SETS OF 4 BLOCKS / STATION AT EACH SIATION. I SET OF 4 BLOCKS

MONTHLY COLONIZATIONS DELETED 3 TRANSECIS II ABOVE

IN JUN, JUL, OCT AND NO AND 2 BELOW] LEAVING I ABOVE AND 4 BELOW

WEEXIY COLONIZATIONS FROM 15 APR THRU 21 JUL MONTIUY COLONIZATIONS BEGINNING IN MAR

DAILY COLECTIONS

SAME AS IN 1971

DELEIED 2 MORE IRANSECTS BELOW DISCHARGE LEAVING 1 ABOVE AND 2 BELOW

3 SIATIONS, 1 ABOVE INTAKE, 1 ALONG DISCHARGE CANAL AND 1 BELOW DISCHARGE CANAL, ALL 3 ON SHORE

BIWEEKLY FROM JUL THRU 2 STATIONS, 1 ABOVE AND 1 BELON NOV WITH NETS SET FOR PLANT

24 HOURS

MONIHLY COLONIZATIONS FROM FEB TIIRU JUL

SAME AS 1973 EXCEPT 3 NEW STATIONS ADDED IN DEC 1973

SAME AS IN 1973 EXCEPT SAMPLED FROM FEB THRU JUI
CLASSIFICATION TO LOWEST JAXONOMIC LEVEL

SAMPLES WERE REIRIEVED, WASHED AND

SEPARAIED FROM $\sim 22.5 \mathrm{~m}^{2}$ OF ROCKS / SAMPLE. ORGANISMS WERE TIIAN CLASSIFIED, COUNTED

AND DRY AND WET WEIGHTS WERE MEASURED

SAMPLES WERE RETRIEVED, WASHED AND

SEPARAIED FROM BLOCK IN THE FIELD.

LABORATORY ANAL YSES INCLUDED CLASSIFYING

COUNIING AND WEIGHING ORGANISMS BY

AVERAGING 4 BLOCK DATA FOR WET AND DRY

WEIGHT/ORGANISM AND TAXONOMIC GROUP

SAME AS IN 1969

SAME AS ABOVE

SAME AS IN 1970

ORGANISMS WERE COUNTED, WEIGHED AND THEN GROWTH WAS DETERMINED FOR EACH WEEK

SAME AS IN 1971

SAME AS IN 1971

SAME AS IN 1972

SAMPLES WERE CLASSIFIED COUNTED AND WEIGHED. EACH MONTH OF DATA SEPARATELY. SUBSAMPLE WEIGHTS WERE PRO JECTED TO REPRESENT THE WHOLE SAMPLE

SAMPLES WERE CLASSIFIED, COUNIED AND WEIGHED AS TOTAL DRIFT/24 HOURS

SAME AS IN 1973

SAME AS IN 1973
REMARKS

QUALITATIVE SIUDY PERFORMED FOR ONE YEAR ONLY

SAMPLING GEAR WAS DEIERMINED JO BE INADEQUATE

RIVER

ADDED NEW S IATIONS FROM 1968 (8 VER SUS 32 AND ELIMINATED THE QUALITATIVE HAND-NETTING

LAST YEAR OF PREOPERATIONAL MONITORING

DUE TO LOW NUMBER OF STONEFL IES COLLECTED BY CONCREIE BLOCKS, A SURBER NET WAS ALSO USED

FIRST YEAR OF OPERATIONAL MONITORING. NO SURBER NET EMPLOYED

DESIGNED TO DETERMINE THE GROWTH AND

RECOLONIZATIONS RATES FOR TIEE BENTHOS AT TWO STATIONS IONE CONTROL AND ONE AT DOWNSIREAM END OF DISCHARGE CANALI

REDUCE SAMPLING FREQUENCY AND INTENSITY

COMPLETED I YEAR STUDY IN JUL ON GROWTH AND RECOLONIZATION RATES

DELEIED 2 MORE IRANSECTS LFAVING 3 WHEN 8 WERE PREOPERATIONALLY SAMPLED. ONLY

ONE MONHI (MAR) DATA WAS REPORIED

STUDY CONTINUED FOR I YEAR TO DETERMINE

REPRODUCTIVE PERIODICITY OF RIVER INSECTS

AND POSSIBLE PREMATURE EMERGENCE. ONLY DAIA FOR NUL AND AUG WERE REPORTED

NETS WERE STACKED VERTICALLY ON TOP OF EACH OTHER FROM BOTTOM TO SUREACE DATA WERE

REPORTED FROM ONLY 3 IIME PERIODS

ONIY DATA FROM FEB - JUL WERE REPORTED

COMPLETED BOTH ONE YEAR SIUDIES 
of adequate growth and colonization rates. The emergent insect survey confirmed a heat-induced seasonal shift in time hatch, but there was no apparent effect on insects after emergence.

IMPINGEMENT AND ENTRAINMENT

Studies of fish entrainment were conducted for approximately 1 full year during 2 calendar years (1973-1974) while impingement studies were begun in July of 1973 and data were available until December of 1974 (Table 10). We evaluated both sets of data as presented in NSP annual reports even though sampling periodicities were very uneven over the intervals of data collection and unusual patterns of "day of the week" data collections were made. Even though both factors might bias the data and our, or NSP's, subsequent estimates of daily mortality, the ultimate assertion of impact rests on information inherent in a population model of the species of interest. Thus, the population estimates made from electrofishing results (tag-recapture) would be of interest in this regard.

\section{ELECTROFISHING}

Results of these studies were reported in each of the years 1968-1969, 1971-1972 and 1973-1974 (Table 9). Unfortunately, the numbers of fish actually caught in each of five sectors were only reported in the first 2-year periods, while percentage distribution of the catch was reported in the second 2-year interval. In the 1973-1974 period, data were reported in graphic form by thermal zones and on a catch per effort basis. Thus, a statistical comparison among 2-year periods was not possible.

We were able to obtain the original electroshocking data sheets for all years from the applicant's consultant. The data could not be quantitatively evaluated because of the following reasons: 1) shocking times were not recorded for 1968,2$)$ no sector differentiation could be ascertained for 1969,3$)$ time intervals between sectors were inconsistent and varied (sometimes two-week differences), and, 4) inconsistent sector shocking pressure, i.e., some sectors had up to ten shocking runs, while others had as 


\section{TABLE 9. Summary of Fish Sampling and Analytical Methods}

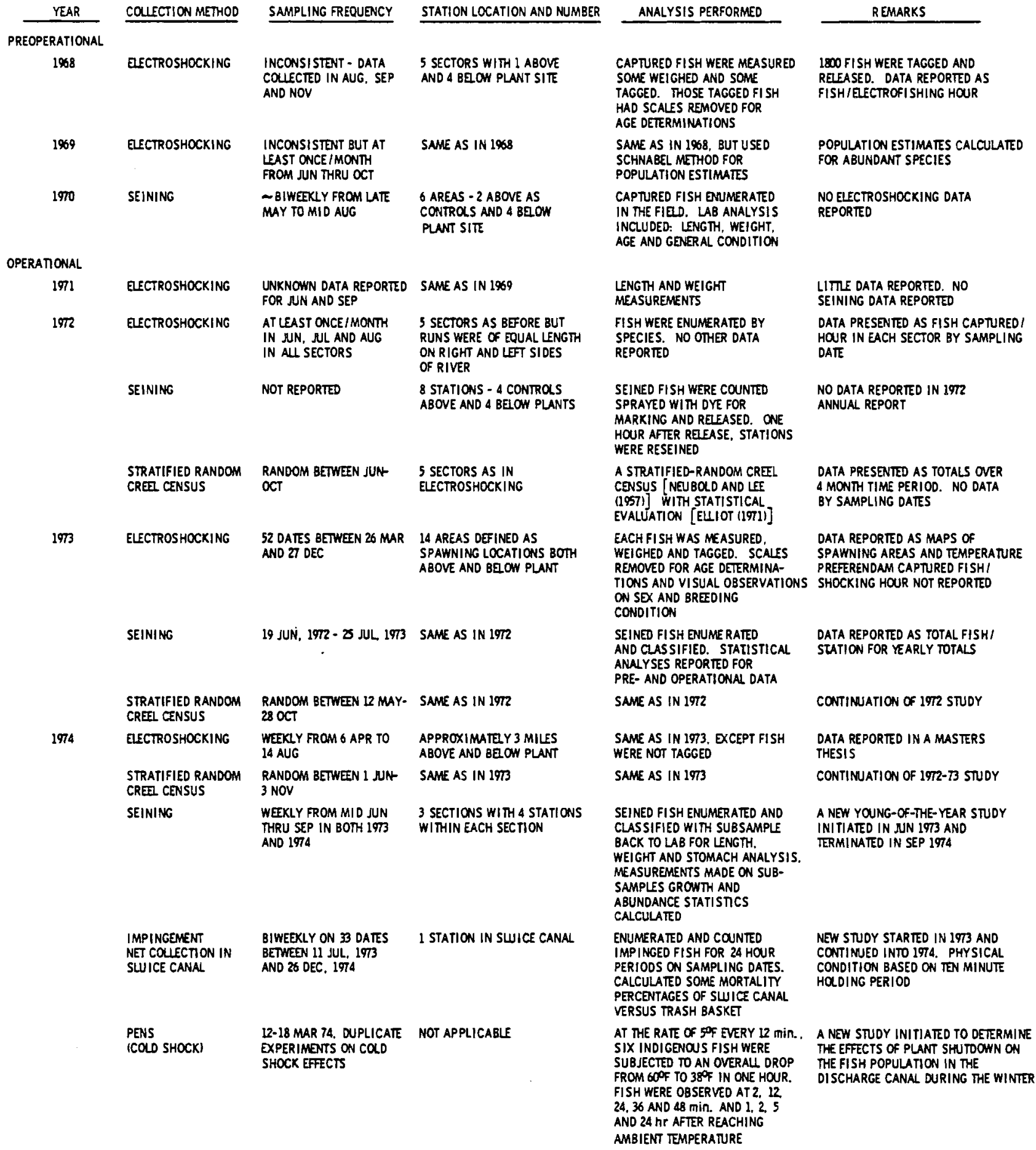


TABLE 10. Summary of Entrainment Sampling and Analytical Methods

\section{YEAR COLLECTION METHOD \\ 1972 LABORATORY-SIMULATION} MODEL OF ENTRAINMENT

FIELD STUDY -

DIP-NETTING AND SEINING

ONCE IN JUN, SEP NOV, DEC AND FEB 1973

BIWEEKLY FROM SEP 73 - AUG 74
NET

\section{STATION LOCATION AND NUMBER}

4 TEST CHAMBERS TO SIMULATE CONDENSER TEMPERATURE RISES AND DISCHARGE CANAL DECREASES

ENTIRE LENGTH OF DISCHARGE CANAL

ONE STATION AT HEAD OF DISCHARGE CANAL
ANALYSIS PERFORMED

FATHEAD MINNOWS WERE PAS SED FROM ONE AQUARIUM TO ANOTHER FOR A PRESCRIBED TIME: $15 \mathrm{seC}$ AT $7.2^{\circ} \mathrm{C} \triangle \mathrm{T}, 10-15 \mathrm{~min}$. FOR A DROP IN TEMPERATURE. BACK TO ACCLIMATION IEMPERATURE AND THEN HELD FOR 7 DAYS AT

ACCLIMATION TEMPERATURE FOR DELAYED MORTALITIES

INTRODUCED FATHEAD MINNOWS (36-60 mm) BETWEEN THE TRAVELLING SCREENS AND

CIRCULATING WATER PUMPS AND RECAPTURED THEM IN THE DISCHARGE CANAL BY DIP NETTING AND SEINING. CAPIURED FISH WERE TRANSPORIED TO LIVE BOXES AT AMBIENT TEMPERATURE AND HELD FOR OBSERVATION AND

EXAMINATION

EACH SAMPLING TIME INCLUDED 6, $15 \mathrm{~min}$. TO $3 \mathrm{hr}$ FISHING TIME OVER A $24 \mathrm{hr}$ PERIOD. FISH WERE PRESERVED, AND THEN WEIGHED IDENTIFIED, ENUMERATED AND VISUALLY EXAMINED
REMARKS

IEMPERATURES AND HOLDING TIMES. SIMULATED PASSAGE THRU FIRST CONDENSER, SECOND CONDENSER. DISCHARGE CANAL AND RETURN TO AMBIENT CONDITIONS

FATHEAD MINNOW NOT INDIGENOUS TO STUDY AREA

THIS STUDY WAS DESIGNED TO EXAMINE NUMBER, KINDS AND SEASONAL OCCURRENCE OF NATURAL ENTRAINMENT. THE STUDY WAS NOT DESIGNED TO DETERMINE SURVIVORSHIP 
few as two runs. We have again summarized these inconsistencies in the result section on fish and in a limited way in Table 9.

As in the studies above, we did attempt an analys is of each 2-year data set.

\section{SEINING}

Two collection periods were available to us, a preoperational study conducted from 26 May 1970 to 20 November 1970 and operational study done between 19 June 1972 and 25 July 1973 (Table 10). Nonuniformity of sampling stations was again a problem because only three were surveyed both times. Further the considerable time between studies and lack of catch per unit effort data makes statistical analys is questionable. Nevertheless since a preoperational study was conducted, we attempted a statistical evaluation of the data.

\section{CREEL CENSUS STUDY}

We did not evaluate these data. because data were only available for operational years and results from a creel census were used for fishing pressure and catch estimates.

\section{COLD SHOCK STUDY}

Our evaluation of this study was qualitative because adequate population size, and field mortality values were not available. 


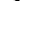


VI. PREDICTED IMPACTS AND TECHNICAL SPECIFICATIONS 



\section{PREDICTED IMPACTS AND TECHNICAL SPECIFICATIONS}

The Environmental Technical Specifications for the Monticello Nuclear Generating Plant have not been finally approved at this writing. A draft has been submitted by Northern States Power Company and is currently being studied by NRC. The draft is divided into five broad categories, which include sections on definitions, limiting conditions for operation, environmental surveillance, special surveillance programs, and administrative controls. Only a portion of Section 3, Nonradiological Surveillance, (Appendix A) is relevant to our study. This section gives the type, duration, methodologies and rationale for monitoring programs to be carried out at Monticello.

Since final Environmental Technical Specifications have not been issued, we used the draft document for the purposes of our study. The absence of final Technical Specifications did not interfere with the analysis of the extensive monitoring data base ( 3 years preoperational and 5 years operational). This long-term accumulation of monitoring information prior to Environmental Technical Specifications development was used as justification for a lesser required monitoring effort.

The objective stated in the draft of the Environmental Technical Specifications is the evaluation of impact of plant operation on the biotic community. Monitoring is required in 3 biotic communities: periphyton, benthic macroinvertebrates, and fish. Requirements for periphyton sampling call for one upstream control station and four stations below the plant outfall, one of which is located outside of the thermal plumes. Biweekly samples are to be collected unless hazardous ice or water conditions prevail. Benthic macroinvertebrates sampling calls for two transects to be investigated for potential effects, one upstream of the plant and one $75 \mathrm{~m}$ below the discharge canal. Each transect is to have at least three stations equidistant from each other with four concrete blocks comprising a station. Monthly sample collections are required. Fish populations are to be sampled primarily by electroshocking and seining with trapnetting augmenting these two methods. 
A creel census is to be performed between May and November to determine the quality of fishing. In addition to the above programs a biweekly fish census is to be conducted to determine fish species distribution and abundance in the discharge canal during the winter months. This data is to be used to predict potential impacts from winter shutdowns (cold shock) and is to be conducted in accordance with Contention II-23 dated 23 october 1974.

In addition to studying effects on the three biological communities, impingement and entrainment programs are to be carried out for at least 2 years after the Technical Specifications are approved. Impingement studies are to be conducted every 2 weeks when the plant is operating and fish entrainment studies are to be conducted from May through August and aquatic insects from May through October. Mortality estimates are to be made on both fish and insects. These data are to be compared with an appropriate control station, to determine effects of impingement and entrainment.

Water quality is also to be studied at three locations on a quarterly basis to determine its effect on the aquatic communities. Sampling stations are situated $100 \mathrm{ft}$ above and below the plant, with a third station in the discharge canal. The parameters to be monitored on a quarterly basis are as follows: dissolved oxygen, $\mathrm{BOD}, \mathrm{pH}$, conductivity, turbidity, current velocity, TDS, total phosphate, ortho-phosphate, nitrate-nitrogen, chlorides, iron and sulfates. Temperature at the intake and discharge is to be continually recorded by the plant computer system.

Predicted FES impacts for Monticello include: 1) alteration of the benthic macroinvertebrate populations in a 5-15 acre area on the plant side of the river, due to the thermal plume, 2) creation of a potential source for cold shock mortality for fish attracted to the discharge canal, and 3) potential mortalities of up to $15 \%$ for drifting organisms due to entrainment. These programs are addresed in the draft Technical Secifications, but since final Technical Specifications have not been approved or implemented we cannot determine whether these Technical Specifications will be responsive to the predicted impacts. However, based on our evaluation of the monitoring programs conducted at Monticello between 1968 and 1974, the draft Technical Specifications basically call for a continuation of those programs. 
The question that needs answering then is: Have the impacts predicted in the Environmental Statement been verified by the data collected from the monitoring programs? Generally speaking the answer has to be no; however, each program should be evaluated separately. The benthic macroinvertebrate program could have detected large changes if they occurred because this program had reasonably good design and collected both preoperational and operational data sets. The periphyton chlorophyll-a analysis showed no statistically significant differences. However, qualitative examination of the data suggested some possible changes, but these had to be rejected on the basis of inconsistencies in the data. Regressions of periphyton count data on distance did show some significant relationships, but these were seasonally dependent on lower total periphyton in an area near the discharge. Without preoperational data sets for comparisons the meaning of these changes is difficult to interpret. Fish studies were evaluated for changes due to operation of the plant but could not be quantitatively assessed because of incomplete and apparently biased monitoring and poor population estimates. Reasons specific for individual fish studies can be found in the appropriate result section. While most of the monitoring programs were usually not designed to answer the question posed above, some programs (i.e., benthic macroinvertebrate) were well designed and more intensive sampling might have detected changes. If more consideration was given to a sampling design that is statistically oriented, which tries to differentiate between natural variation and plant induced effects, then answers to predicted FES impacts could possibly be attained through a highly quantitative Environmental Technical Specifications. 


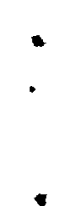


VII. ANALYSIS OF MONITORING DATA 



\section{ANALYSIS OF MONITORING DATA}

\section{THERMAL MONITORING}

Three programs provided data for thermal analysis. Each was designed for different purposes and consequently these data must be evaluated separately. The first program, thermal survey, was used to evaluate the accuracy of model prediction (page 32 ). The second program, water quality temperature monitoring, was evaluated to determine: 1) distribution of excess heat downstream of the discharge, and 2) as support data to impact considerations. The periphyton temperature data (the third program) were examined for usefulness as a covariable to evaluate thermal effects on the biota.

\section{THERMAL SURVEY RESULTS}

Even though data from 13 of 34 runs were abailable for examination, only a few of these relate to thermal plume model predictions. For purposes of our evaluation the following cases were considered:

1. Summer, 4000 cfs river flow, cooling tower operation in the helper mode.

2. Summer, 1200 cfs river flow, cooling tower operation in the helper mode.

3. Summer, 1200 cfs river flow, once-through cooling.

4. Winter, 500 cfs river flow, once-through cooling.

For Case 1 the results of the model prediction are shown in Figure 18 [taken from the Environmental Report, Figure V-2, pg. V-5, employing the method of Asbury and Frigo (1971)]. Results from the thermal survey are shown in Figure 19 (taken from Supplement 1 to the Environmental Report). A constant value $\left(11^{\circ} \mathrm{F}\right)$ was used for excess discharge temperature in all calculations with helper tower cooling. For once-through cooling, the excess discharge temperature employed for model calculations was $26.8^{\circ} \mathrm{F}$. 
Comparing Figure 18 and 19 , one observes that the model predictions are considerably below the survey results for the far field. Even when adjusted for the difference in excess discharge temperature, the far field predictions are about $1 / 2$ of the measured far field maximums (far field being considered as 3 miles downstream). It should be noted that the usual summer excess discharge temperature is closer to $13^{\circ} \mathrm{F}$ than the $11^{\circ} \mathrm{F}$ employed in the model. The areal extent of the surface excess temperature isotherms is also greater for the survey results than for the model predictions, particularly in the far field. This case is purported to be the usual summer case.

The model predictions for Case 2 are shown in Figure 20 (taken from the Environmental Report, Figure V-5, pg. V-8). Likewise the survey measurements for this case are shown in Figure 21 (taken from Supplement 1 to the Environmental Report). The conditions in Case 2 are supposedly an unusual summer condition because of the low river flow (1200 cfs). Comparison of the results illustrated in the two figures indicates that the far field maximum surface temperatures are underpredicted by the model, as are the areal extent of the isotherms. The "unusually" low summer flow (near $1140 \mathrm{cfs}$ ) persisted for nearly 2 months during the summer of 1971, so the results illustrated in Figure 21 are the rule for that summer rather than the exception.

The normal cooling mode for summer operation is.with the cooling towers in operation. (An agreement between Northern States Power Company and the State of Minnesota requires the operation of the cooling towers whenever the ambient river temperature exceeds $68^{\circ} \mathrm{F}$ ). However, should the cooling towers become inoperable during the summer, and the plant remains operating, the cooling mode would be once-through. The Environmental Report gave model predictions for a once-through cooling mode and a low summer river flow (1200 cfs). The predicted surface isotherms for this case (Case 3 ) are shown in Figure 22. A thermal survey made on 8/19/71 (Supplement 1 to the Environmental Report) gave temperature distributions for the conditions of Case 3; the results are shown in Figure 23. A comparison of the results shown in Figures 22 and 23 indicates good agreement, both in downstream maximum excess temperatures and in isotherm areal extent. This case, however, is considered unique because once-through cooling is unlikely to occur at unusually low river flow. 


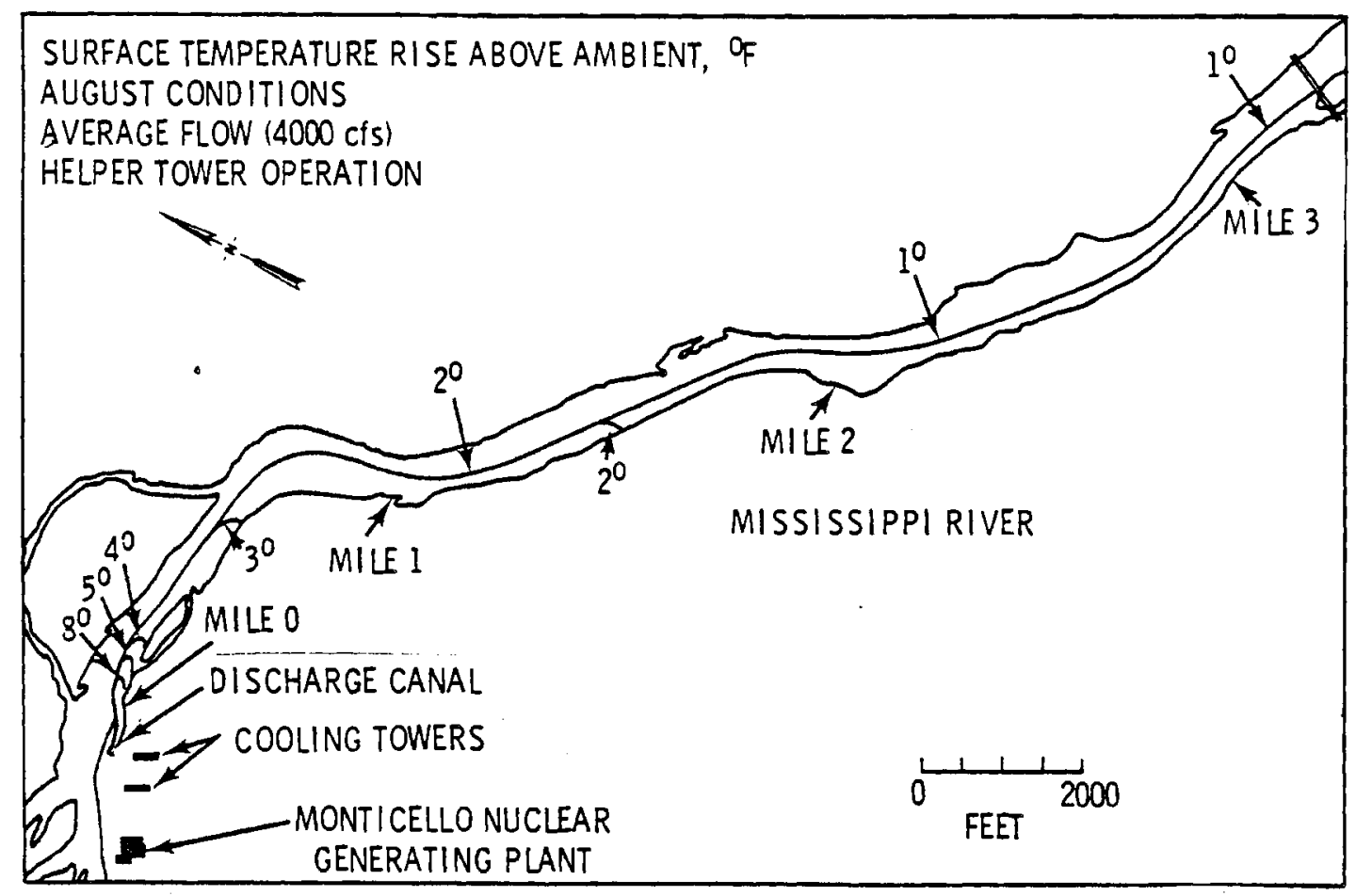

FIGURE 18. Surface Temperature Rise Predictions, August Average Flow, Helper Tower Operation

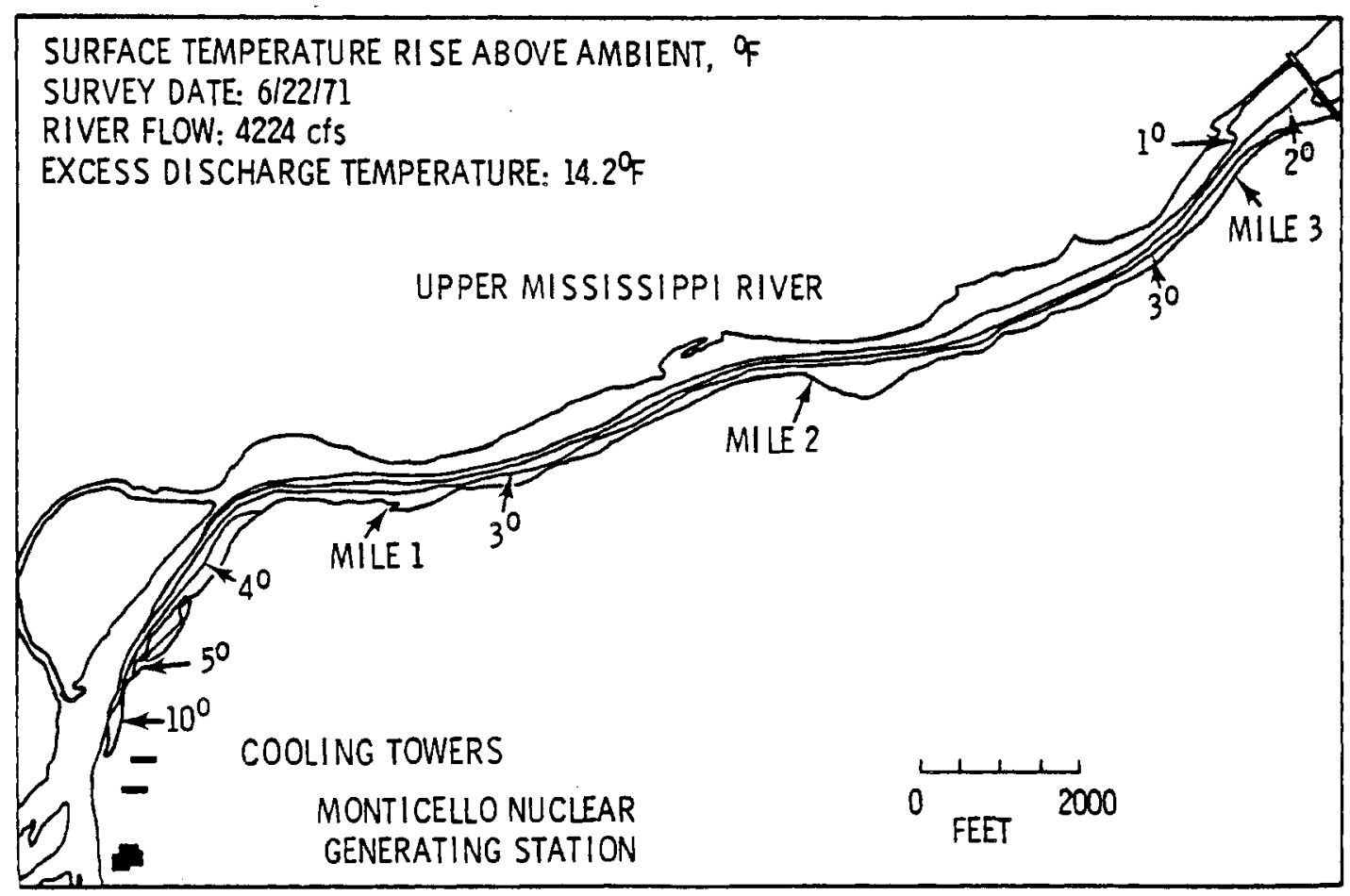

FIGURE 19. Therma 7 Survey Surface Temperature Rise of $6 / 22 / 71$, A River Flow of $4224 \mathrm{cfs}$, and an Excess Discharge Temperature of $14.2^{\circ} \mathrm{F}$ 


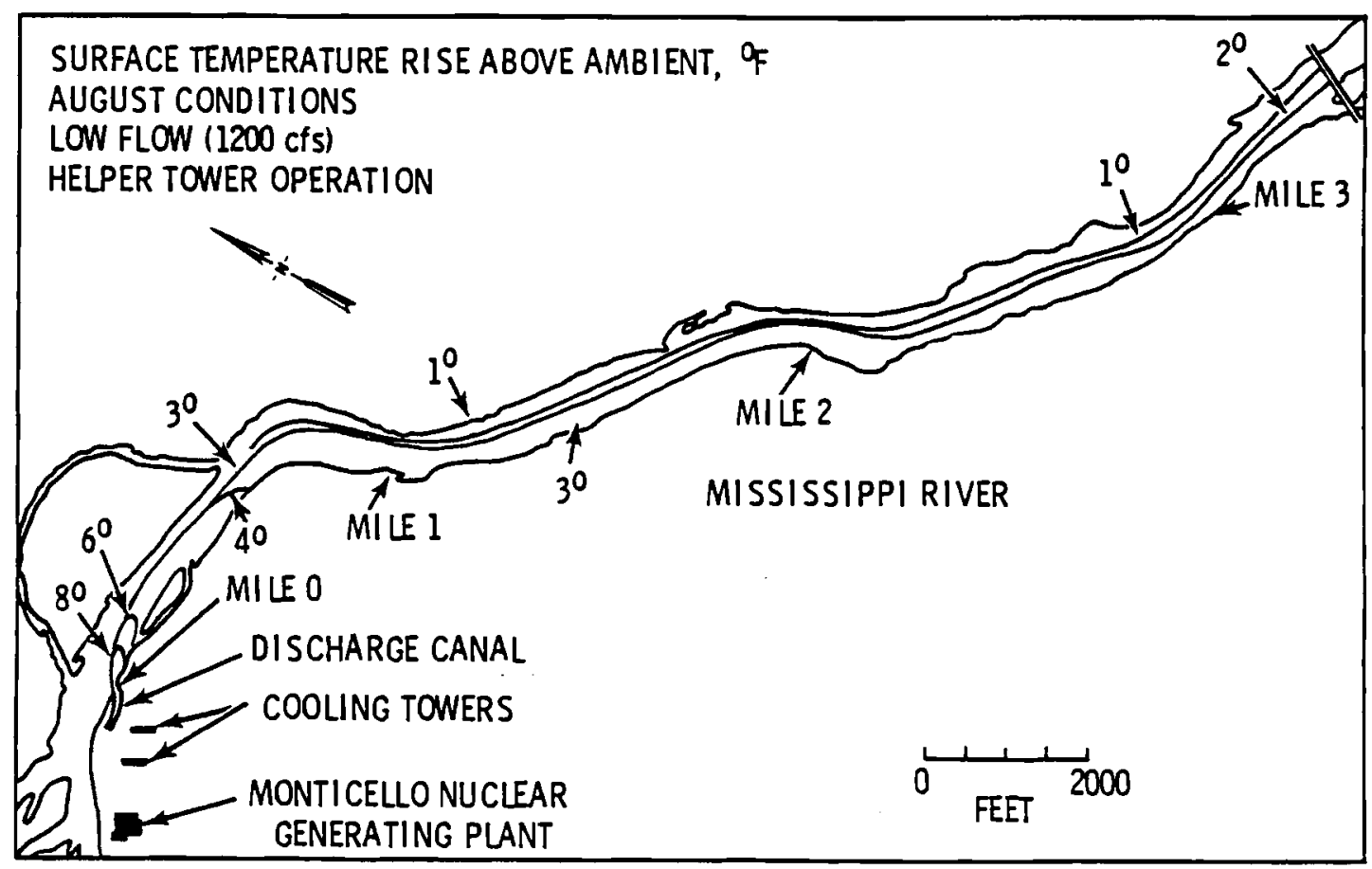

FIGURE 20. Surface Temperature Rise Predictions, August, Low Flow, Helper Tower Operation

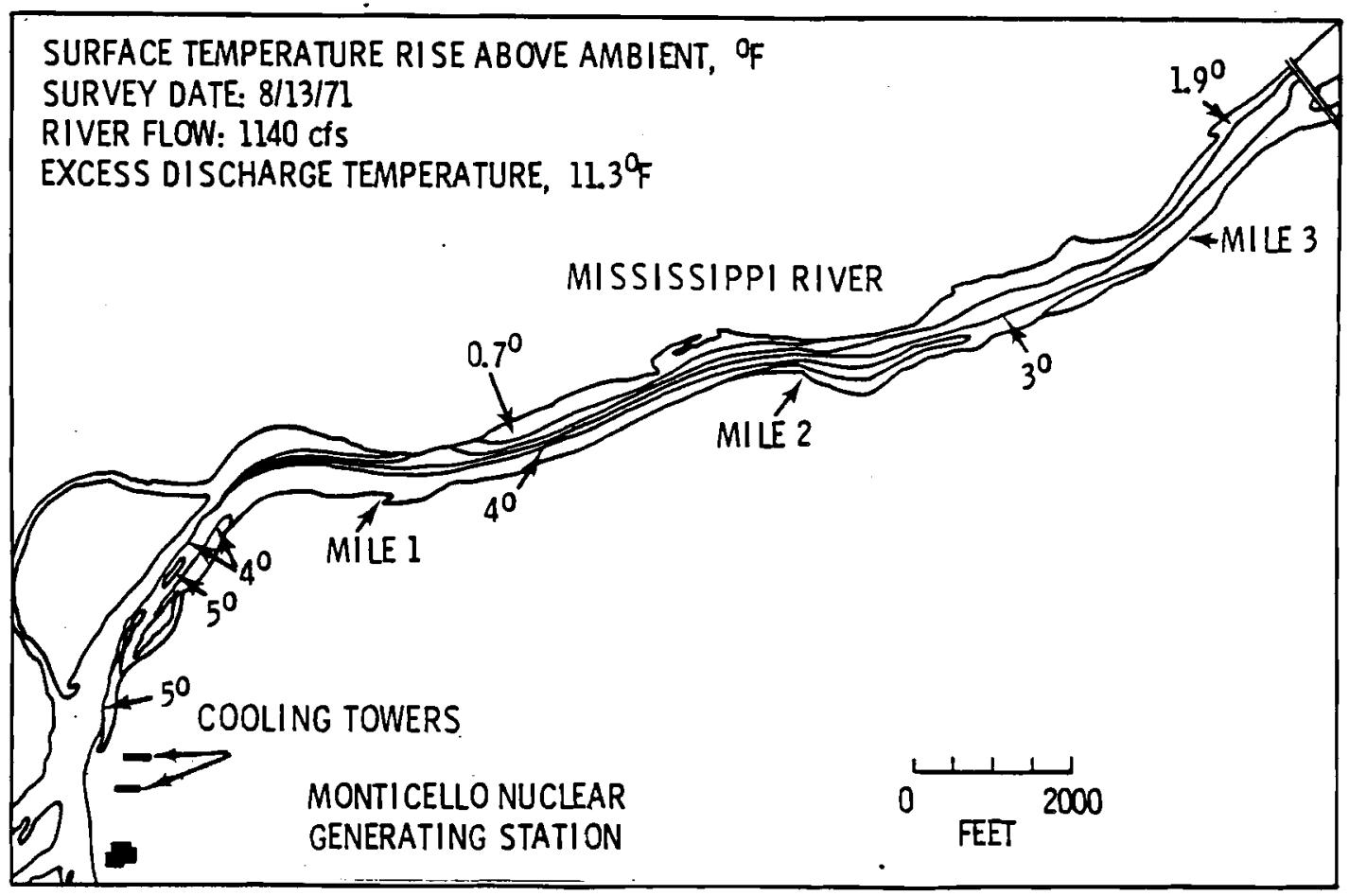

FIGURE 21. Thermal Survey Surface Temperature Rise for $8 / 13 / 71$, a River Flow of $1140 \mathrm{cfs}$, and an Excess Discharge Temperature of $11.3^{\circ} \mathrm{F}$ 


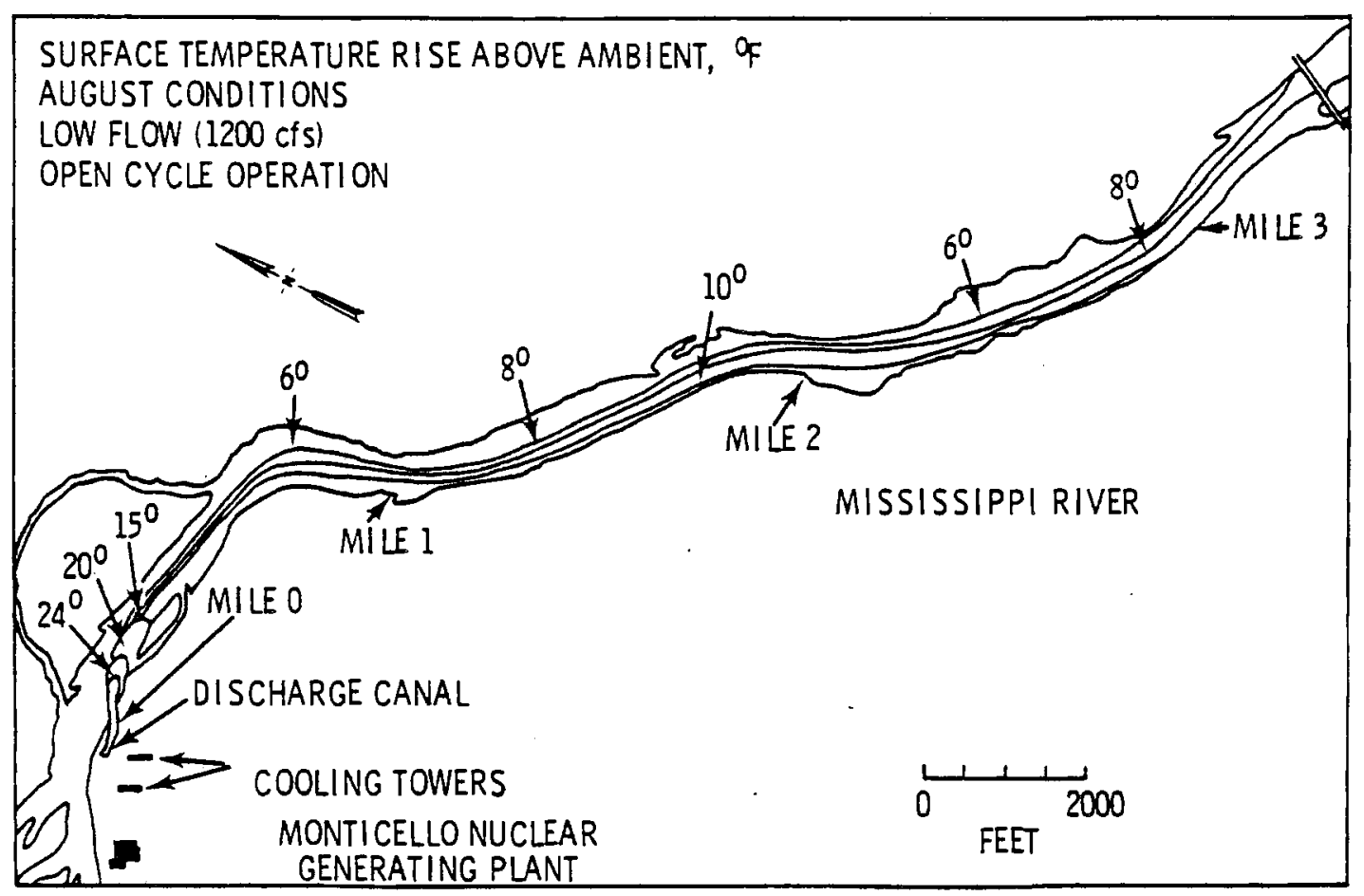

FIGURE 22. Surface Temperature Rise Predictions, August, Low Flow, Open Cycle Operation

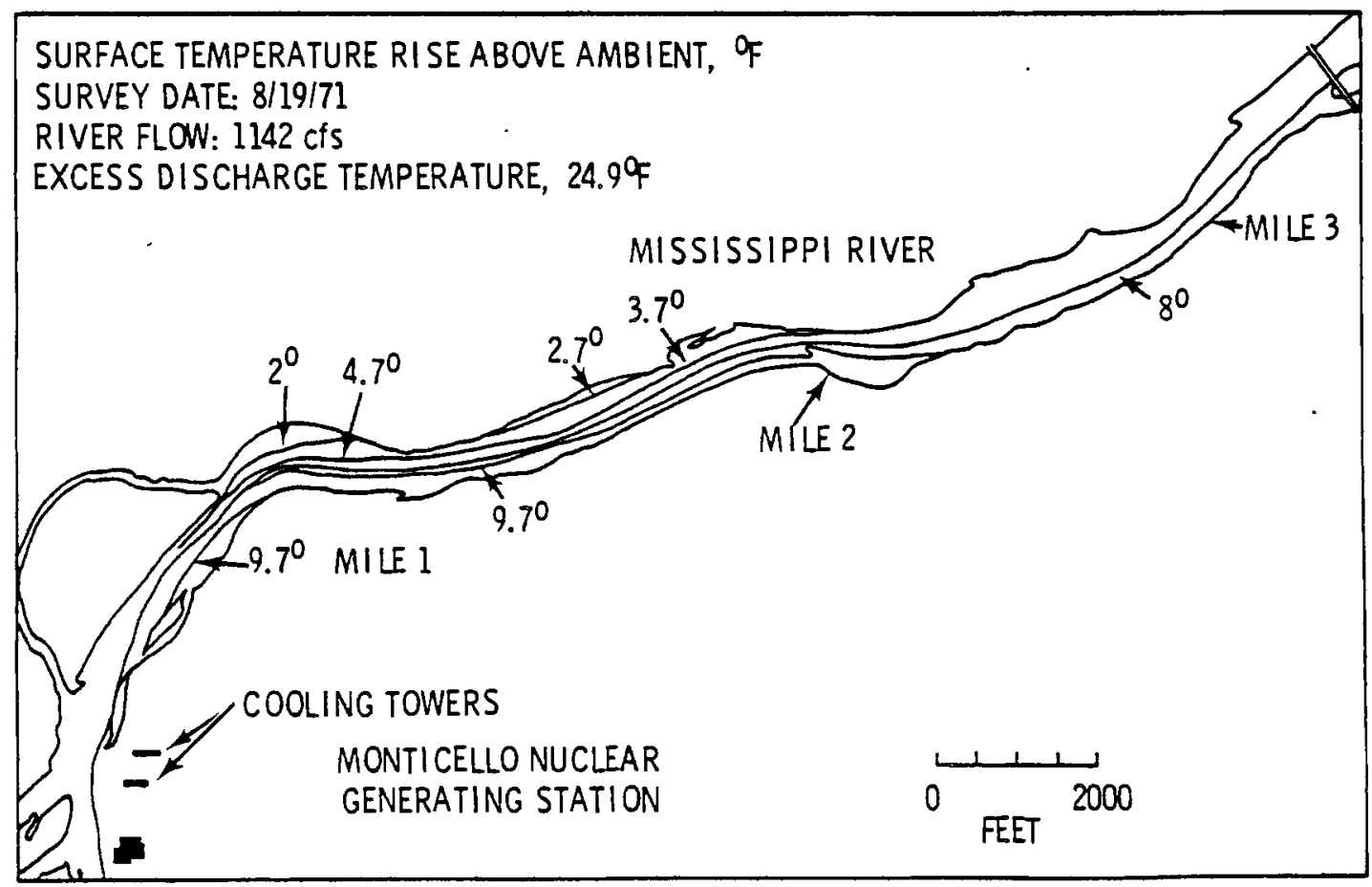

FIGURE 23. Thermal Survey Surface Temperature Rise for $8 / 19 / 71$ a River Flow of $1142 \mathrm{cfs}$, and an Excess Discharge Temperature of $24.9^{\circ} \mathrm{F}$ 
The final case, Case 4, is for normal winter operation, i.e., river flow about $3500 \mathrm{cfs}$, and once-through (open cycle) cooling. Unfortunately, the model predictions available were for a river flow of 2500 cfs, Figure 24. The nearest survey case is shown in Figure 25, and is for a river flow of $3840 \mathrm{cfs}$. The comparison should be fairly accurate, since the river velocities and mixing characteristics are not greatly different at these flows. A comparison of the model predictions (Environmental Report, figure V-4, pg. $V-7$ ) to the survey results (Supplement 1 to the Environmental Report) shows that the predicted maximum far field excess temperatures are higher than those surveyed, as are the isotherm areas. This may be attributed to the containment of the effluent by the surface ice, to the difference in river flows noted above, or most likely to the lack of model consideration of heat transfer to the atmosphere.

In general, the model predictions are not representative of the river surface thermal distribution. The failure of observed and predicted data to agree indicates that the model was not sufficiently grounded in the physical principles to allow accurate prediction at conditions other than those for which phenomenological data already existed. Since little information is available concerning the manner in which the model was assembled, specific recommendations for model improvement cannot be made.

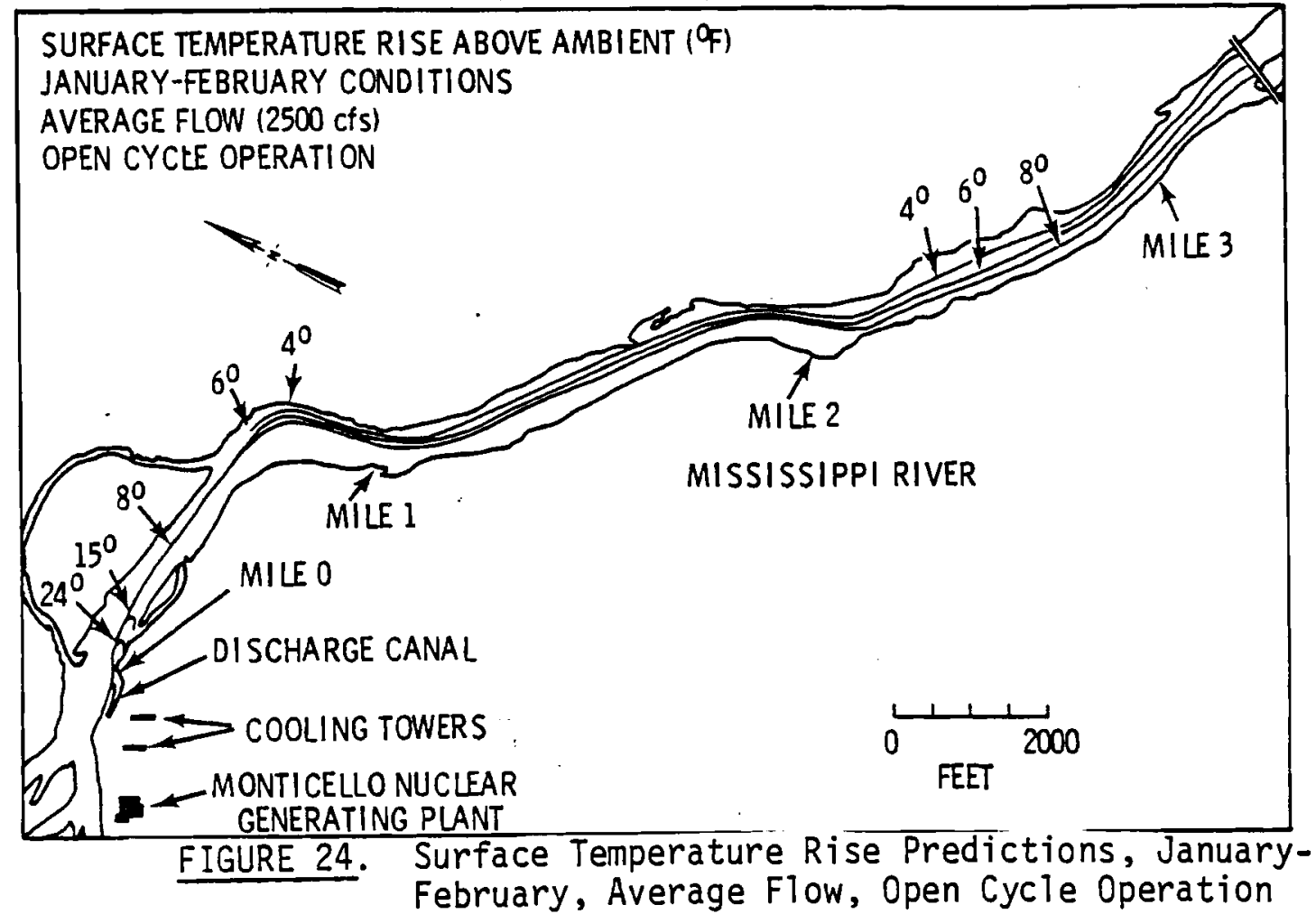




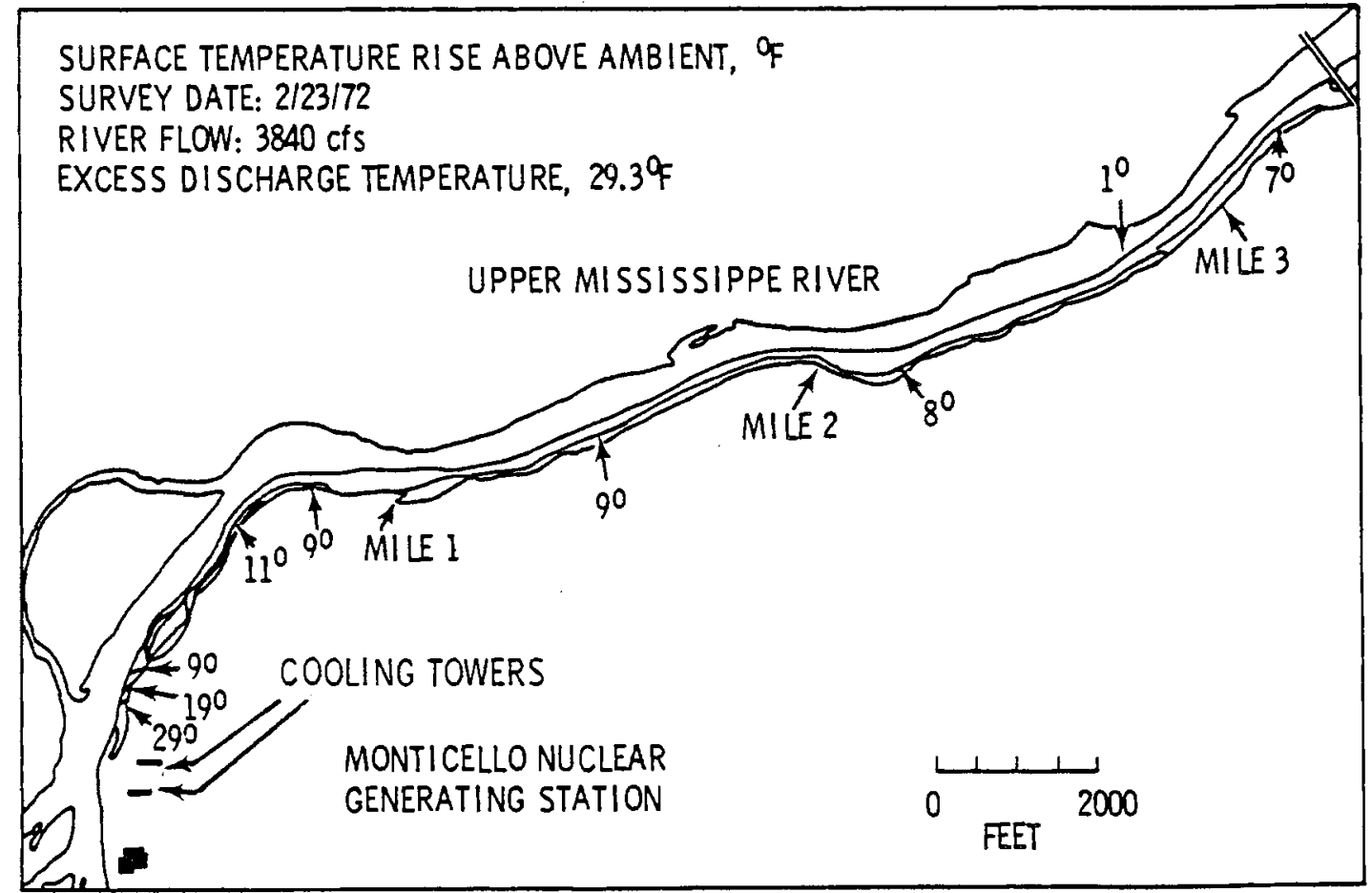

FIGURE 25. Thermal Survey Surface Temperature Rise for $2 / 23 / 72$, a River Flow of $3840 \mathrm{cfs}$, and an Excess Discharge Temperature of $29.3^{\circ} \mathrm{F}$

\section{WATER QUALITY TEMPERATURE MONITORING RESULTS}

Weekly temperatures were measured at nine stations to characterize the preoperational and operational thermal nature of the river downstream of the discharge point. The stations were sited near the southwest shore where temperatures were likely to be the highest. Weekly reporting of data does not allow maximum use for model verification. However its principal purpose was in support of thermal impact predictions. The usefulness of the data is hindered by a considerable amount of missing measurements. As a tool for model verification, the data near the discharge are unacceptable because the temperatures were recorded near the bottom of the river rather than at the surface. Since there is significant stratification near the discharge, temperatures were not the maximum in the plume. The vertical temperature structure of the river at several close cross-sections is shown in Figure 26, taken from the thermal survey of August 13, 1971 (Supplement 1 to the Environmental Report). Considering these crosssectional profiles one notes that the river remains somewhat stratified 


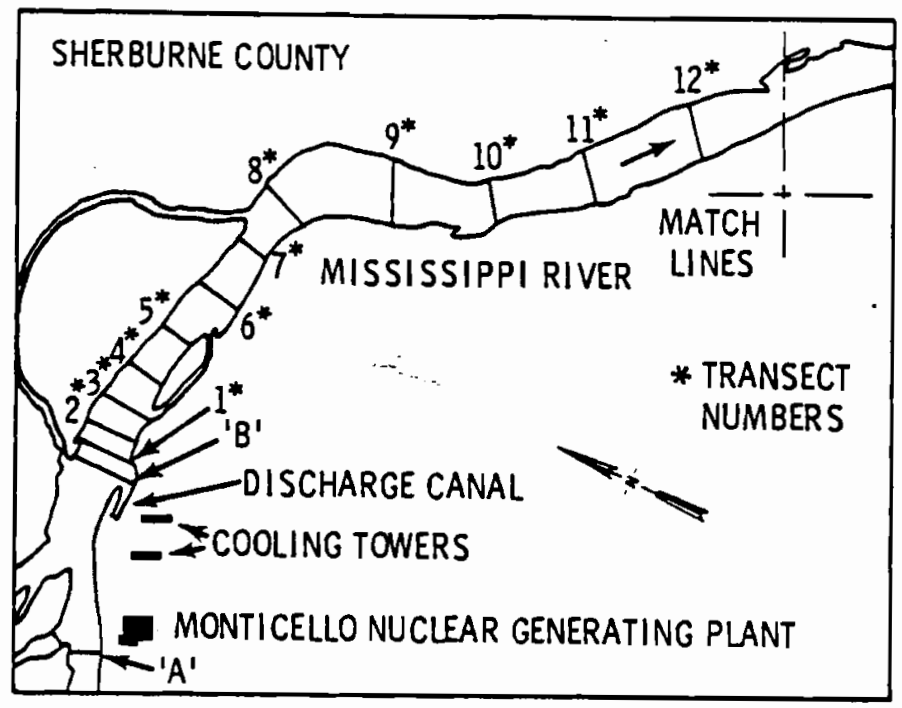

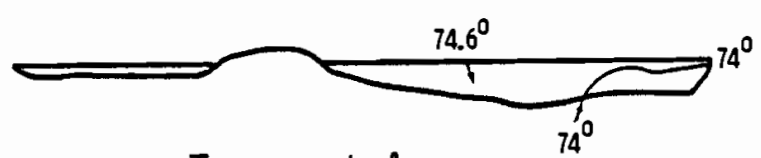

Transect A

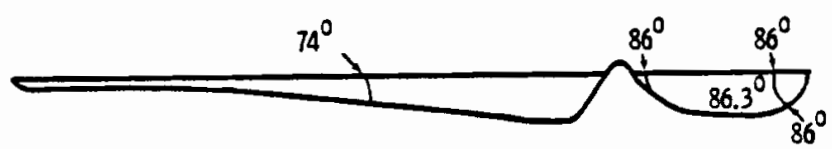

Transect B
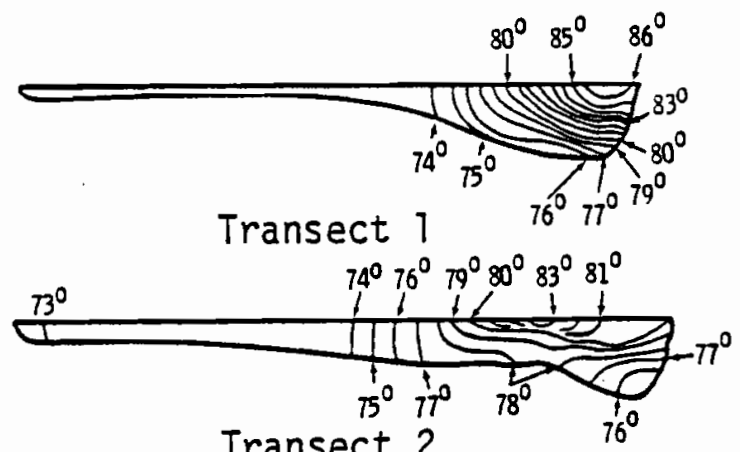

Transect 2

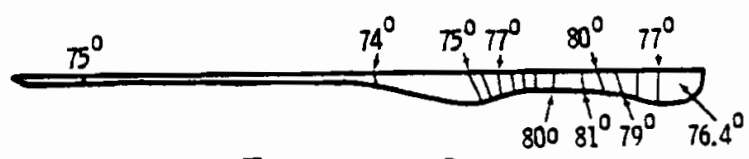

Transect 3
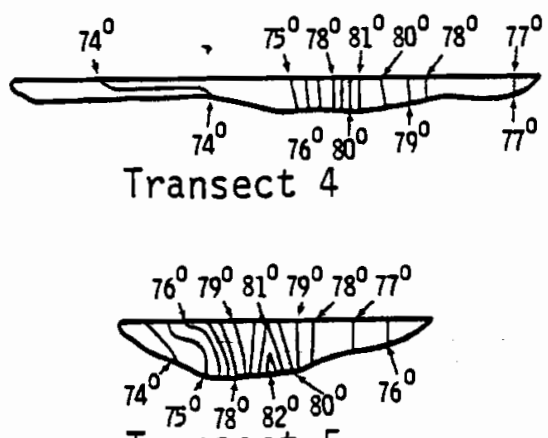

Transect 5

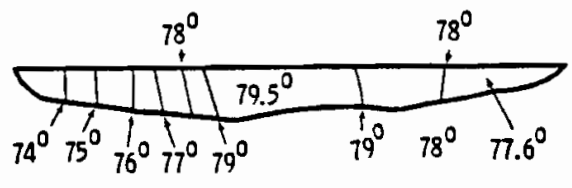

Transect 6

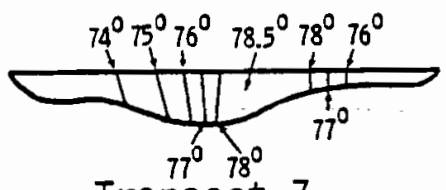

Transect 7

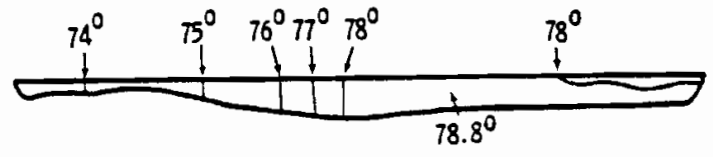

Transect 8

FIGURE 26. Vertical Thermal Structure at Downstream Cross-Sections 
until Transect 3, some 500 feet downstream from the discharge point. This means that the true maximum plume temperatures were not measured in the water quality program until at least Station 4. Even then, this is uncertain because the lateral positions of the temperature sensors (i.e., the distances from the shore) were not reported.

Because of the above factors, the water quality program temperatures were probably less than the maximum plume temperatures. For purposes of this analysis the reported water quality program temperature data have been averaged over each month and are presented in Appendix $B$ for 9 months. The data for the preoperational years 1969 and 1970 are offered as control data and the ordinate temperatures are the differences between the reported values at Stations 3 through 9 and that of Station 2 (control station). When examining these data, note that the plant may not have been operating during certain periods. The data for March, August, and September are in Figures 27,28 and 29. Since the plant did not begin operation until May of 1971, the 1971 data for March are actualiy preoperational values. The data shown in Figure 27 compare well with the data offered earlier for the winter condition, although there may be a small amount $\left(1-2^{\circ} \mathrm{F}\right)$ of suppression from maximum plume temperatures since the sensors are located offshore by some unknown distance. Likewise, the data for August 1971 agree with the low flow thermal survey data presented in the prior section. The data offered in Figure 29 for September also support the survey results presented for summer 1971 conditions when the cooling towers were in full operation. The figure further suggests that the plant operated in open cycle in September of 1972. If temperatures at downstream Stations 6 through 9 are elevated more than $9^{\circ}$ or $10^{\circ} \mathrm{F}$ above the Station 2 values, one may assume that the cooling mode is once-through with a reduced cooling water flow (less than $640 \mathrm{cfs}$ ). (Such cases seem to have occurred in October and November of 1972, see Appendix B). The data offered in Appendix $B$ may be considered representative of the excess bottom temperatures likely to be encountered in future years provided the current cooling mode patterns are continued. 


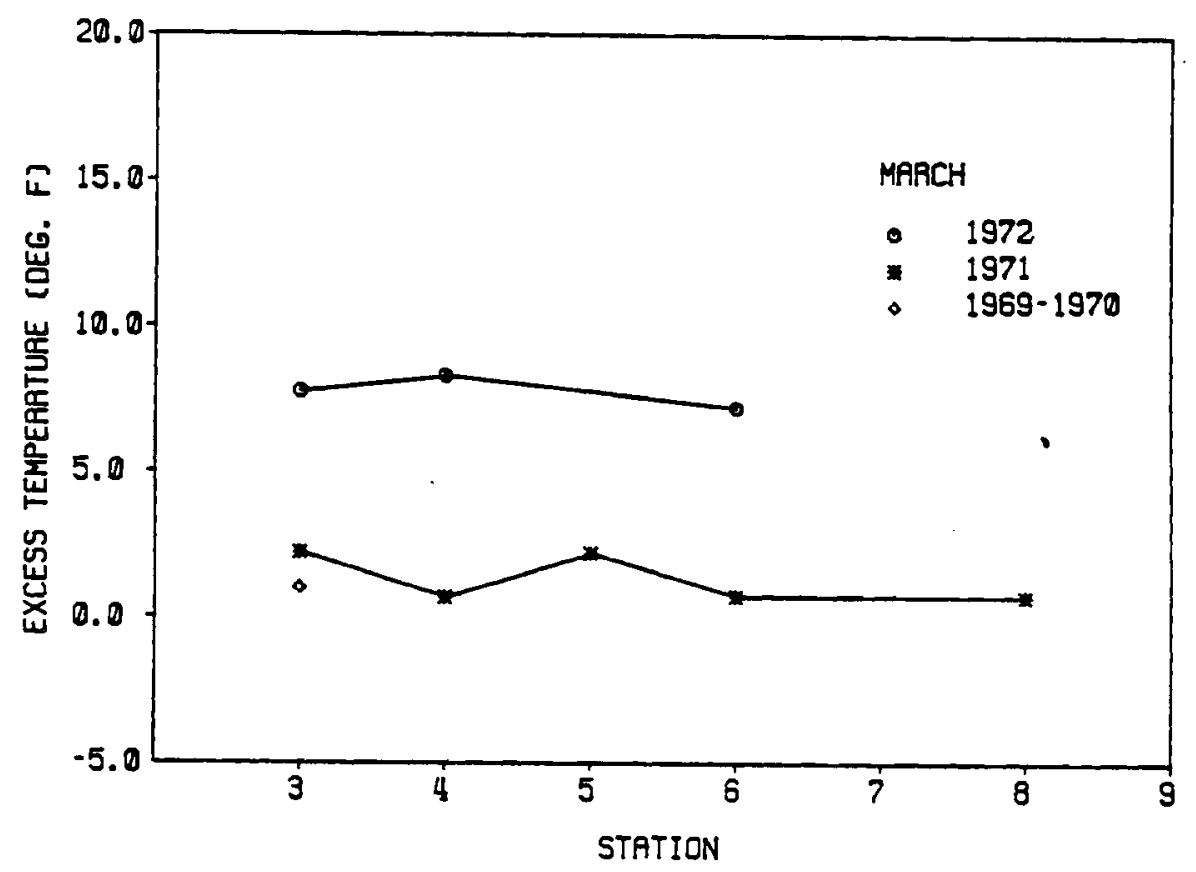

FIGURE 27. Excess Temperature Compared

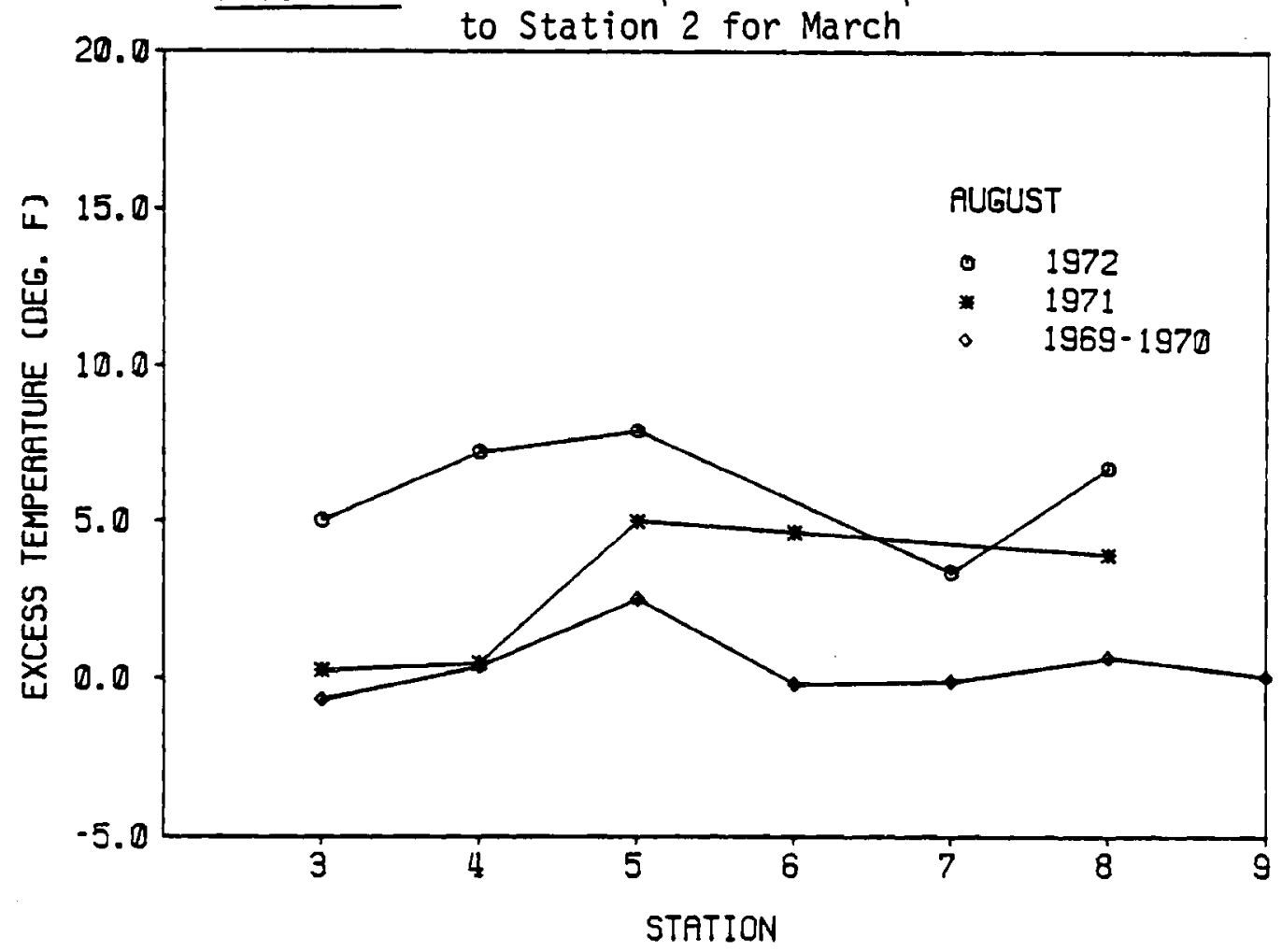

FIGURE 28. Excess Temperature Compared to Station 2 for August 


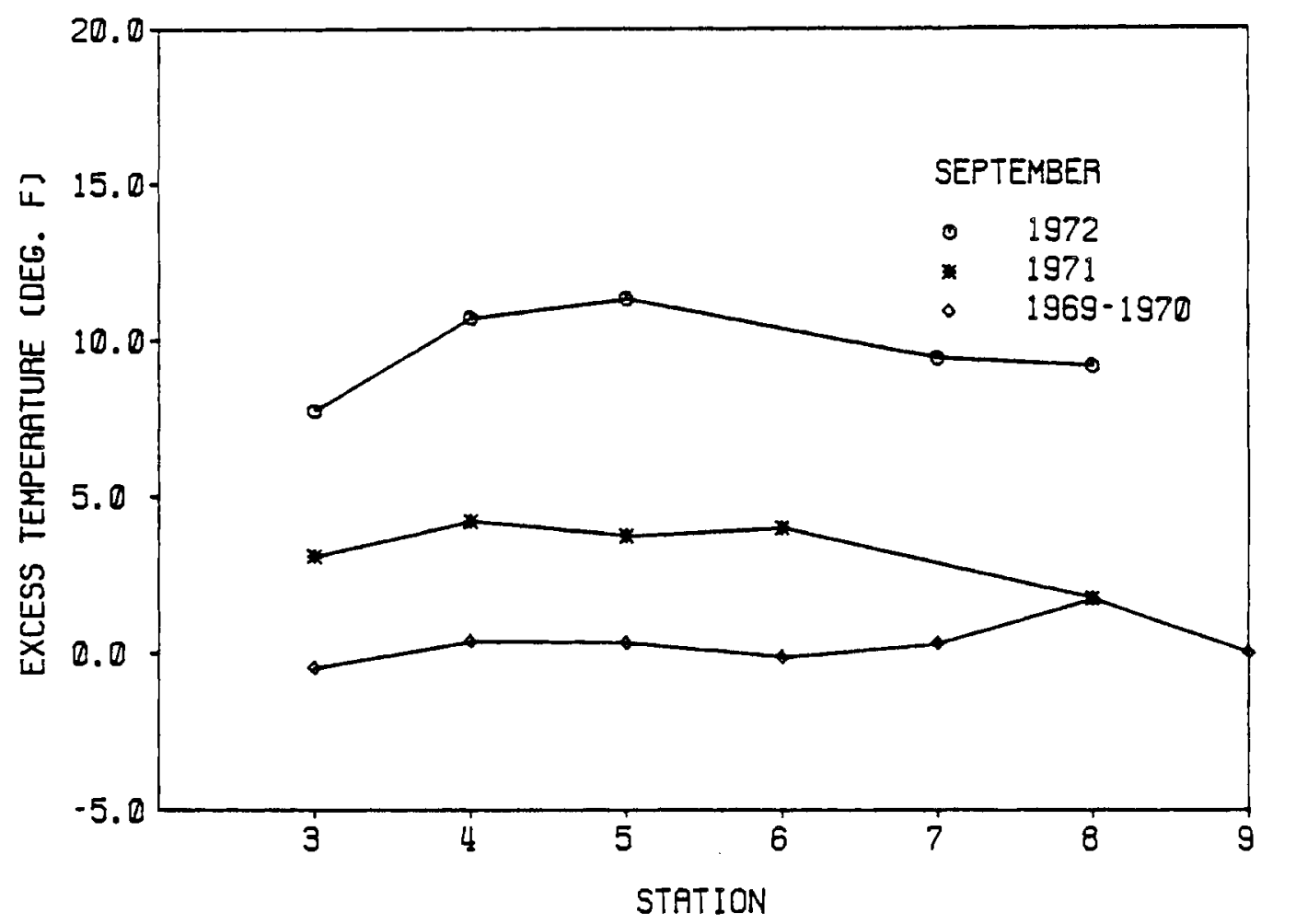

FIGURE 29. Excess Temperature Compared to Station 2 for September

\section{PERIPHYTON TEMPERATURE MONITORING}

The temperature data presented in the periphyton monitoring program are of limited value for model verification or thermal impact support. For the purposes of this study only the data from the upstream (control) Station 2, the canal Station 3A, and the downstream stations within the plume, 3,6 , and 11 are of concern. Temperature data collected in conjunction with the periphyton study are given in Table 11. Only cases when there are data for at least Stations 2 and $3 A$ and when there was a near normal plant load are included in Table 11. This data is represented as dimensionless excess temperature ratios in Table 12. Although the sample size is small, thermal characteristics of the plume as it progresses downstream are readily evident. Taking averages at Stations 3, 6, and 11 for the summer (June, July, August), autumn (September, October), and winter [November, January (one record), February (one record)] may help to characterize the thermal plume; the averaged excess temperature ratios are as follows: 
TABLE 11. Periphyton Monitoring Excess Temperature, ${ }^{\circ} \mathrm{F}$ (Relative to Station 2)

\begin{tabular}{|c|c|c|c|c|c|}
\hline Date & Control & & leated & ions & \\
\hline & 2 & $3 A$ & 3 & 6 & 11 \\
\hline $7 / 09 / 71$ & 73.9 & 11.0 & 8.1 & 6.1 & 3.1 \\
\hline $8 / 05 / 71$ & 68.0 & 12.1 & 5.0 & 4.0 & 3.1 \\
\hline $9 / 30 / 71$ & 59.9 & 19.8 & 6.3 & 6.1 & 5.4 \\
\hline $10 / 14 / 71$ & 53.2 & 14.8 & 2.2 & 7.2 & --- \\
\hline $10 / 28 / 71$ & 51.4 & 13.0 & 0.0 & 1.8 & --- \\
\hline $5 / 09 / 72$ & 53.6 & 30.6 & 3.6 & 2.7 & 3.2 \\
\hline $5 / 22 / 72$ & 68.0 & 13.0 & 2.3 & 2.3 & 3.2 \\
\hline $6 / 05 / 72$ & 70.0 & 11.0 & 2.5 & 3.2 & 3.2 \\
\hline $6 / 19 / 72$ & 67.6 & 16.6 & 5.8 & 3.8 & 5.6 \\
\hline $7 / 04 / 72$ & 69.6 & 12.8 & 5.2 & 5.4 & 4.7 \\
\hline $8 / 15 / 72$ & 75.6 & 14.9 & 3.1 & 5.4 & 4.7 \\
\hline $9 / 01 / 72$ & 69.8 & 11.7 & 0.9 & 2.7 & 2.7 \\
\hline $9 / 18 / 72$ & 63.5 & 29.7 & -- & 7.2 & 8.1 \\
\hline $10 / 03 / 72$ & 53.6 & 32.4 & --- & --- & 7.2 \\
\hline $10 / 16 / 72$ & 43.7 & 40.5 & 5.4 & 10.8 & 7.2 \\
\hline $11 / 01 / 72$ & 39.2 & 30.6 & 4.5 & 8.1 & 7.2 \\
\hline $11 / 28 / 72$ & 32.0 & 38.0 & 3.1 & 12.1 & 4.1 \\
\hline $1 / 16 / 73$ & 32.0 & 36.0 & --- & 14.9 & --- \\
\hline $2 / 16 / 73$ & 32.0 & 39.6 & --- & 15.3 & --- \\
\hline $5 / 22 / 73$ & 63.3 & 22.9 & 7.4 & 8.3 & 8.5 \\
\hline $6 / 05 / 73$ & 68.9 & 20.7 & 8.1 & 6.3 & 6.3 \\
\hline $7 / 02 / 73$ & 75.2 & 11.2 & 6.3 & 4.5 & 5.4 \\
\hline $7 / 17 / 73$ & 75.2 & 10.8 & 4.5 & 3.6 & 4.5 \\
\hline $8 / 14 / 73$ & 73.8 & 10.1 & 4.1 & 2.5 & 3.2 \\
\hline $8 / 28 / 73$ & 72.5 & 14.8 & 5.9 & 2.9 & 3.6 \\
\hline $9 / 11 / 73$ & 65.7 & 26.1 & 9.5 & 8.6 & 7.7 \\
\hline $9 / 24 / 73$ & 62.8 & 21.8 & 6.1 & 5.2 & 5.4 \\
\hline $10 / 09 / 73$ & 63.5 & 11.3 & 5.4 & 5.4 & 5.4 \\
\hline $11 / 09 / 73$ & 33.8 & 35.1 & 6.5 & 13.0 & 8.1 \\
\hline $11 / 23 / 73$ & 37.4 & 30.6 & 11.2 & 10.4 & 7.2 \\
\hline $5 / 23 / 74$ & 57.2 & 16.2 & 7.2 & 3.6 & 3.6 \\
\hline $6 / 25 / 74$ & 70.7 & 9.9 & 2.7 & 2.7 & 2.7 \\
\hline $7 / 09 / 74$ & 80.6 & 8.1 & 1.8 & 1.8 & 3.6 \\
\hline $7 / 23 / 74$ & 78.8 & 9.0 & 3.6 & 3.6 & 4.5 \\
\hline $8 / 05 / 74$ & 72.1 & 10.3 & 2.7 & 3.1 & 3.1 \\
\hline $8 / 20 / 74$ & 77.0 & 9.9 & 4.5 & 4.5 & 3.6 \\
\hline $9 / 04 / 74$ & 62.6 & 23.2 & 7.0 & 6.3 & 6.3 \\
\hline $9 / 19 / 74$ & 64.9 & 27.4 & 6.7 & 6.7 & 6.7 \\
\hline $10 / 76 / 74$ & 46.4 & 28.4 & 7.2 & --- & -- \\
\hline $10 / 31 / 74$ & 51.8 & 28.8 & 9.0 & 7.2 & 7.2 \\
\hline
\end{tabular}




$$
\begin{aligned}
& \text { Excess temperature ratio for: } \\
& \text { Summer- Station } 3=0.34 \\
& \text { Station } 6=0.34 \\
& \text { Station } 11=0.35 \\
& \text { Station } 3=0.25 \\
& \text { Station } 6=0.30 \\
& \text { Station } 11=0.27 \\
& \text { Sutumn }=0.19 \\
& \text { Station } 3=0.35 \\
& \text { Station } 6=0.21
\end{aligned}
$$

The summer measurements show the plume excess temperature ratio is nearly constant over the three stations. The autumn measurements show the plume excess temperature ratio being reasonably constant although the possibility of stratification at Station 3 and the effects of increased atmospheric heat exchange between Station 6 and Station 11 are exhibited. Stratification or considerable lateral displacement off the plume centerline are indicated by the winter measurements. Similarly, increased winter atmospheric heat transfer may be indicated by the results for Station 11 . The above results are considered preliminary and unsupportable since little is known concerning the distances from the shore to the measurement stations and because of the sparcity of data.

The excess temperature ratios offered above for each season may be used as gross approximations to the downstream temperatures, however the results from either two previously discused monitoring programs are better suited to this purpose. 
TABLE 12. Periphyton Excess Temperature Ratios, $\left(\Delta T_{C} / \Delta T\right)$

\begin{tabular}{|c|c|c|c|}
\hline \multirow[b]{2}{*}{ Date } & \multicolumn{3}{|c|}{ Station } \\
\hline & 3 & 6 & 11 \\
\hline $7 / 09 / 71$ & 0.74 & 0.56 & 0.28 \\
\hline $8 / 05 / 71$ & 0.42 & 0.33 & 0.25 \\
\hline $9 / 30 / 71$ & 0.32 & 0.31 & 0.27 \\
\hline $10 / 14 / 71$ & 0.15 & 0.49 & --.- \\
\hline $10 / 28 / 71$ & -..- & 0.14 & --.- \\
\hline $5 / 09 / 72$ & 0.12 & 0.09 & 0.11 \\
\hline $5 / 22 / 72$ & 0.18 & 0.18 & 0.25 \\
\hline $6 / 05 / 72$ & 0.23 & 0.30 & 0.30 \\
\hline $6 / 19 / 72$ & 0.35 & 0.23 & 0.34 \\
\hline $7 / 04 / 72$ & 0.41 & 0.42 & 0.37 \\
\hline $8 / 15 / 72$ & 0.20 & 0.36 & 0.31 \\
\hline $9 / 01 / 72$ & 0.08 & 0.23 & 0.23 \\
\hline $9 / 18 / 72$ & --- & 0.24 & 0.27 \\
\hline $10 / 03 / 72$ & --- & ---- & 0.22 \\
\hline $10 / 16 / 72$ & 0.13 & 0.27 & 0.18 \\
\hline $11 / 01 / 72$ & 0.15 & 0.26 & 0.24 \\
\hline $11 / 28 / 72$ & 0.08 & 0.32 & 0.11 \\
\hline $1 / 06 / 73$ & --- & 0.42 & ---- \\
\hline $2 / 16 / 73$ & -..- & 0.39 & -..- \\
\hline $5 / 22 / 73$ & 0.32 & 0.36 & 0.37 \\
\hline $6 / 05 / 73$ & 0.39 & 0.30 & 0.30 \\
\hline $7 / 02 / 73$ & 0.56 & 0.40 & 0.48 \\
\hline $7 / 17 / 73$ & 0.42 & 0.33 & 0.42 \\
\hline $8 / 14 / 73$ & 0.41 & 0.25 & 0.32 \\
\hline $8 / 28 / 73$ & 0.40 & 0.20 & 0.24 \\
\hline $9 / 11 / 73$ & 0.37 & 0.33 & 0.30 \\
\hline $9 / 24 / 73$ & 0.28 & 0.24 & 0.25 \\
\hline $10 / 09 / 73$ & 0.48 & 0.48 & 0.48 \\
\hline 11/09/73 & 0.18 & 0.37 & 0.23 \\
\hline $11 / 23 / 73$ & 0.36 & 0.34 & 0.24 \\
\hline $5 / 23 / 74$ & 0.44 & 0.22 & 0.22 \\
\hline $6 / 25 / 74$ & 0.27 & 0.27 & 0.27 \\
\hline $7 / 09 / 74$ & 0.22 & 0.22 & 0.44 \\
\hline $7 / 23 / 74$ & 0.40 & 0.40 & 0.50 \\
\hline $8 / 05 / 74$ & 0.26 & 0.30 & 0.30 \\
\hline $8 / 20 / 74$ & 0.45 & 0.45 & 0.36 \\
\hline $9 / 04 / 74$ & 0.30 & 0.27 & 0.27 \\
\hline $9 / 19 / 74$ & 0.24 & 0.24 & 0.24 \\
\hline $10 / 16 / 74$ & 0.25 & $-\cdots$ & --. \\
\hline $10 / 31 / 74$ & 0.31 & 0.25 & 0.25 \\
\hline Note: & $T_{3 A}$ & & \\
\hline & tint & & ation $i$ \\
\hline Note: & $\begin{array}{l}74 \\
\text { as }\end{array}$ & 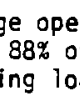 & \\
\hline
\end{tabular}




\section{ECOLOGICAL PROGRAMS}

BENTHOS

Introduction

Benthic data were evaluated using three different statistical approaches: 1) an "overview" of the entire data set via an analysis of variance, 2) a ratio approach suggested by Eberhardt (1976), and 3) a nonparametric procedure to test for statistically significant changes due to position (station) or time. The entire set of count data is listed by organism, station, and time in Appendix $C$. In addition, total counts and percentage of total accounted for by organism are also in Appendix $C$ for the 2 years when total macroinvertebrates were reported. Appendix $C$ also contains complete ratio data sets in both arithmetic and logarithmic units and the ratios are again listedby organism, station, and time. It should be noted that statistical tests were run on data sets when a large number of comparisons were made so that some of the significant results $(P<.05)$ were to be expected.

Control-to-experimental station ratios were calculated based on what we believe would have been the a priori choices because of common position in the river (i.e., see sampling plan in Figure 8 and the associated discussion of Section $V$ ). Further, we did not use data from any station more than once, in an effort to approximate statistical "independence." In addition, one station ratio (E2L/E2E) was used in our analysis based on the report that heated water did not reach the left side of the river (Hopwood, 197.5) and that the benthos therein were unaffected by reactor operations. Overview (Analysis of Variance)

While missing data problems are not unusual in ecological field studies, reference to the original count data in Appendix $\mathrm{C}$ illustrates two additional complications. First, the number of sampling stations within a transect were unequal and data are missing in an irregular pattern. The second complication arose because certain downstream (within transect) stations were always in the thermal plume, some were in the plume only part of a year, while others were never in the plume (Table 13). 
TABLE 13. Thermal Status of Stations Within Transects

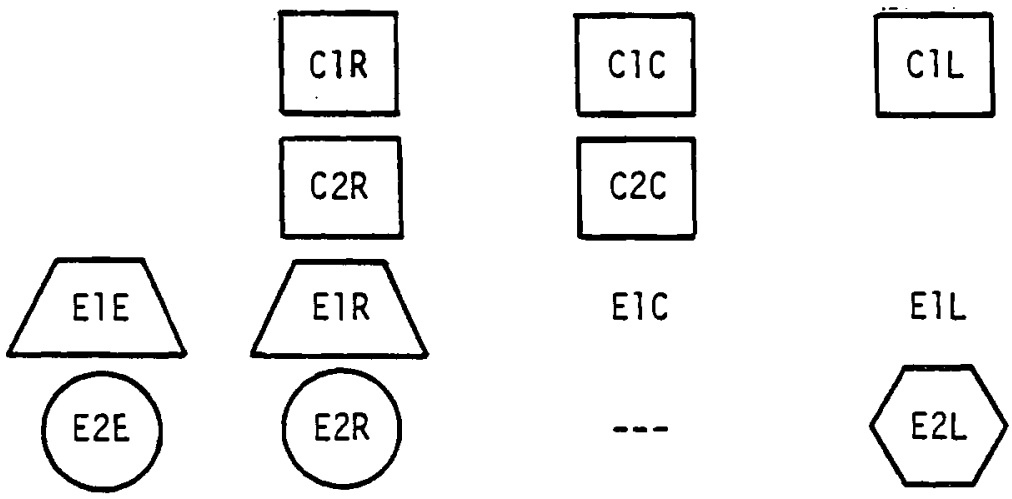

Never in discharge area, controls

In intermediate discharge area ${ }^{(1)}$

$\square$ In outer discharge area $\square \quad \begin{aligned} & \text { In outer discharge area but temperature the } \\ & \text { same as ambient }\end{aligned}$

no
symbol Never in discharge area

(1) Even though Transect E1 is closer to the discharge canal than E2, E2 is in the intermediate discharge area. These descriptions of discharge are given in: Effects of a Heated Discharge on the Ecology of the Mississippi River, (316(a) Type I Demonstration on the Monticello Nuclear Generating Plant, Monticello, Minnesota) p 110. Prepared by NUS Corporation, Pittsburg, PA.

Since some of the factors or effects were "nested" or observed within another effect, the analys is of variance used was a nested and crossed, model (Table 14) with the complications introduced as discussed above. Because of the extreme imbalance in the data, we were unable to apply any of the usually available computer programs (i.e., BMD, SPSS, STATPK, etc.) to this problem. However, a computer routine appropriately acronymed MAD (Modified Abbreviated Doolittle), was obtained from Brigham Young University, to compute the necessary analyses of variance. When large 


\section{TABLE 14. Statistical Model Used as an "Overview" of Each Macroinvertebrate Group}

Effect

Operational Status
Year Within $\begin{aligned} & \text { Preoperational Period } \\ & \text { Operational Period }\end{aligned}$
Months
Transect Location $\begin{aligned} & \text { Upstream } \\ & \text { Downstream, In Plume } \\ & \text { Downstream, Not In Plume }\end{aligned}$
Site Within $\left\{\begin{array}{l}\text { Upstream } \\ \text { Downstrea, In Plume } \\ \text { Downstream, Not In Plume }\end{array}\right)$ Transect
Two Factor Interactions

Operational Status $\times$ Months

Operational Status $x$ Transect Location

Operational Status $\times$ Site Within Transects

Year Within Operational Status $x$ Months

Year Within Operational Status $x$ Transect Location

Year Within Operationai Status $\times$ Site Within Transects

Months $x$ Transect Location

Months $x$ Site Within Transects

Error
Symbol

\begin{tabular}{l}
$A_{i}$ \\
$B_{j(i)}$ \\
$C_{k}$ \\
$D_{i}$ \\
$F_{m(1)}$ \\
\hline
\end{tabular}

$(A C)_{\text {ik }}$

$(A D)_{i 1}$

$(A F)_{i m(i)}$

$(B C)_{j k}(i)$

$(B D) j l(i)$

(BF) jm(i1)

$(C D)_{k}$

(CF $)_{\mathrm{km}}(1)$

All Other Interactions
Range

$i=1,2$

$j=1,2,3$

$k=1-8(2,5,6,7,8,9,10,11)$

$1=1,2,3$

$m=1,2,3,4$ 
amounts of data are missing the magnitude of various effects is dependent on the order which variables are entered; significance may also be affected. Thus, in the results reported in Table 15, variable $C$ (months) was forced to enter each analysis first because we found it consistently affected estimates of other effects. We used the common logarithm of the observed count data plus one to obtain the results shown in Table 15.

TABLE 15. Results of Analys is of Variance of Abundance . for Six Macroinvertebrate Groups Reported

\begin{tabular}{|c|c|c|c|c|c|c|}
\hline \multirow[b]{3}{*}{ Effect (1) } & \multicolumn{6}{|c|}{ Organism } \\
\hline & \multicolumn{2}{|c|}{$\begin{array}{l}\text { Caddisfilies } \\
\text { Hydronsyche and }\end{array}$} & \multirow{3}{*}{$\frac{\frac{\text { Midges }}{\text { Chironomini }}}{?}$} & \multirow{2}{*}{$\begin{array}{l}\text { Black Flies } \\
\text { Simulidae }\end{array}$} & \multicolumn{2}{|c|}{ Mayflies } \\
\hline & Cheuma topsyche & Macronemum & & & Stenonema & Baetis \\
\hline$A_{i}$ & & & & * & & \\
\hline$B_{j(i)}$ & & & & & & * \\
\hline$c_{k}$ & * & * & & * & * & * \\
\hline$D_{1}$ & & $?$ & & & & * \\
\hline$F_{m(z)}$ & * & $?$ & * & * & * & \\
\hline$(A C)_{i k}$ & & & & & & \\
\hline$(A D)_{i 1}$ & & & & & & \\
\hline$(A F)_{\text {im }(l)}$ & & & & * & & \\
\hline$(B C)_{j k(i)}$ & $\star$ & * & * & * & * & * \\
\hline$(B D)_{j 1(i)}$ & & & & & * & \\
\hline$(B F)_{j m(i 1)}$ & & & & & & \\
\hline$C D_{k} 1$ & & * & & & & \\
\hline$C F_{\mathrm{km}(\ell)}$ & * & * & & * & & * \\
\hline Error Variance & 0.51 & 0.89 & 0.53 & 2.07 & 0.77 & 0.37 \\
\hline $\begin{array}{l}\text { Number of } \\
\text { Observations }\end{array}$ & 262 & 161 & 267 & 263 & 257 & 221 \\
\hline
\end{tabular}

* Always significant $(P<0.05)$ regardless of the ordering of input variables

? Significance $(P<0.05)$ dependent on the ordering of input variables

(i) See Table 9 for the meaning of these symbols. 
The datum of interest, used to detect changes in population numbers due to plant operation, is the operational status by transects interaction term $(A D)$. However, this interaction was not significant $(P<0.05)$ for any of the organisms studied, while the operational status by site within transects interaction (AF) term was only statistically significant for Simulidae. Reference to the calculated error variances shows that this organism exhibited a value not in accord with those for the other macroinvertebrates studied. One reason for this larger variance is suggested below.

Among the main effects studied, site within transects, $F$, and months, $C$, were often both statistically significant $(P<0.05)$ for each benthic organism. This result would have been predicted by most field ecologists as would the significant interactions observed for months by year within the operational or preoperational periods $(B C)$. Thus, our statistical analysis was unable to detect a change due to plant operation but the statistically significant location and time differences one would normally expect were present. When interpreting the analysis above, several notes of caution seem advisable. First, the F-tests were calculated assuming a random effects model (even though all effects were not random) with expected mean squares and degrees of freedom approximated as shown by the example calculations in Tables 16 and 17 (Guenther, 1964). Secondly, reference to Appendix $C$ shows that considerably fewer observations were available for most macroinvertebrates (particularly for control stations) during 1972-1973. Therefore, most of the statistical analysis was based on two preoperational (1969, 1970) and one operational year (1971). In some of the tables and figures which follow, we indicate specifically where the amount of operational data appeared to be inadequate. 
TABLE 16. An Example of the Calculation of One Interaction F-Test

- TEST CF (MONTHS $\times$ SITE WITHIN TRANSECTS)

$$
\begin{aligned}
& 1_{E M S} \text { CF. } \sim \sigma_{E}^{2}+0.550 \sigma_{C F}^{2}=2.422 \\
& { }^{2} E M S\left[E \quad \sim \sigma_{E}^{2}=0.959\right. \\
& F(19,177) \sim 2.42210 .959=2.526 * *
\end{aligned}
$$

- estimate oCf (NEEDED FOR THE CALCULATION OF OTHER TESTS)

$$
\begin{aligned}
& 0.059+0.550 \hat{\sigma}_{C F}^{2}=2.422 \\
& \hat{\sigma}_{C F}^{2}=2.66
\end{aligned}
$$

$$
\begin{aligned}
& * * \quad=\text { SIGNIFICANT AT O.01 LVVEL } \\
& 1_{\text {EMS }}=\text { EXPECTED MEAN SQUARE } \\
& 2_{E}=\text { ERROR }
\end{aligned}
$$

TABLE 17. Schematic Example Calculation of Degrees of Freedom for F-Tests

GIVEN $M_{i}=$ INDIVIDUAL MEAN SQUARES

$$
M^{\prime}=\sum_{i} a_{i} M_{i}
$$

WHERE M MAS $n_{i}$ DF

$$
\begin{aligned}
a_{i} \text { IS MULTIPLIER } \\
M \sim x^{2}\left(n^{\prime}\right) \\
\text { WHERE }_{n^{\prime}}=\frac{\left(M^{\prime}\right)^{2}}{\sum_{i} \frac{\left(a_{i} M_{i}\right)^{2}}{n_{i}}}
\end{aligned}
$$


Nonparametric Tests

Because of the skewed characteristics of benthos count distributions, we used the common logarithm plus one of the data in the analysis of variance previously discussed. In order to examine the data in the absence of a distributional assumption, Wilcoxon's Signed Rank Test was used to compare control and experimental stations for each macroinvertebrate reported. Our assumption that the various data sets are from the same unknown distribution seems reasonable, but we doubt that the serial observations in time (even though benthos colonized new concrete blocks each month) can be assumed to be uncorrelated random variables.

Results of our comparison of individual stations (Table 18 and Table 19) gives an overall summary of the findings. Reference to the column labeled $P$ (Table 18), under the macroinvertebrate Baetis, shows that there were statistically significant $(P<0.05)$ differences among stations in the preoperational (CIC versus EIC and C2R versus E2R) and operational (CIL versus EIL and C2R versus E2R) periods. Further, the four associated rank sums were all positive (column labeled $s$ ) with respect to the control station, indicating that control numbers were significantly higher than numbers enumerated at the corresponding experimental stations. The summarized results for Baetis in Table 20 indicate that two control stations had significantly (probability for significance relaxed to 0.10 , thus an increased Type II error) higher numbers of Baetis during the preoperational period compared to counterpart downstream stations and this difference remained unchanged during reactor operation. In contrast, numbers of Baetis observed at two other control stations were statistically indistinguishable from counterpart downstream stations during operation even though they had been significantly different during the preoperational period. The final station comparison (E2L versus E2E) showed no significant change during either period. Further, other statistically significant changes similar to those for Baetis occurred for other macroinvertebrates. However, the overall results in Table 19 show a nearly equal total number of significant changes during preoperational and operational periods and a predominance of no significant changes. This supports the conclusion that there is no demonstrable overall effect (or 
impact) on the benthic community due to the operation of the Monticelio Plant. However, we again were able to show statistically significant $(P<0.05)$ differences in numbers of benthic organisms between stations on both the same and different transects (Table 18). This latter point is illustrated graphically in Figure 30, using only the $\mathrm{Cl}$ transect data, where we show that counts for certain stations in the transect are consistently higher or lower during portions of the 3-year period depicted.

TABLE 18. Comparison of Station Macroinvertebrate Counts Using Wilcoxon's Signed-Ranks Test

\begin{tabular}{|c|c|c|c|c|c|c|c|c|c|c|}
\hline \multirow[b]{2}{*}{ Organism } & $\begin{array}{c}\text { Station } \\
\text { Comparisons }\end{array}$ & \multicolumn{3}{|c|}{$\begin{array}{c}\text { Preoperationa] } \\
1969-1970 \\
\end{array}$} & \multicolumn{3}{|c|}{$\begin{array}{c}\text { Operationa } \\
1971-1973 \\
\end{array}$} & \multicolumn{3}{|c|}{$\begin{array}{c}\text { Operational and } \\
\text { Preoperational } \\
\text { 1969-1973 }\end{array}$} \\
\hline & Control Plume & (n) & $(P)^{(2)}$ & $(s)^{(1)}$ & $(n)$ & (P) & (s) & $(n)$ & (P) & (s) \\
\hline $\begin{array}{l}\text { Caddisfly } \\
\text { Macronemum }\end{array}$ & $\begin{array}{l}\text { CIC VS. EIC } \\
\text { C1L VS. EIL } \\
\text { C2R VS. E2R } \\
\text { CIR VS. EIR } \\
\text { E2L VS. E2E }\end{array}$ & $\begin{array}{l}7 \\
6 \\
9 \\
4 \\
6\end{array}$ & $\begin{array}{l}0.45 \\
0.91 \\
0.01 \\
0.07 \\
0.05\end{array}$ & $\begin{array}{l}+ \\
+ \\
+ \\
+\end{array}$ & $\begin{array}{l}3 \\
3 \\
3 \\
3 \\
3\end{array}$ & $\begin{array}{l}0.59 \\
0.29 \\
1.00 \\
0.11 \\
0.11\end{array}$ & $\begin{array}{l}(3) \\
(3) \\
(3) \\
(3) \\
(3)\end{array}$ & $\begin{array}{r}10 \\
9 \\
12 \\
7 \\
9\end{array}$ & $\begin{array}{l}0.68 \\
0.59 \\
0.01 \\
0.02 \\
0.01\end{array}$ & $\begin{array}{l}+ \\
+ \\
+ \\
+\end{array}$ \\
\hline $\begin{array}{l}\text { Mayflies } \\
\text { Baetis }\end{array}$ & $\begin{array}{l}\text { CIC VS. EIC } \\
\text { C1L VS. EIL } \\
\text { C2R VS. E2R } \\
\text { CIR VS. EIR } \\
\text { E2L VS. E2E }\end{array}$ & $\begin{array}{r}12 \\
10 \\
11 \\
10 \\
9\end{array}$ & $\begin{array}{l}0.03 \\
0.09 \\
0.01 \\
0.06 \\
0.72\end{array}$ & $\begin{array}{l}+ \\
+ \\
+ \\
+ \\
+\end{array}$ & $\begin{array}{l}5 \\
5 \\
7 \\
5 \\
6\end{array}$ & $\begin{array}{l}0.23 \\
0.04 \\
0.02 \\
0.89 \\
0.46\end{array}$ & $\begin{array}{l}+ \\
+ \\
+ \\
+ \\
+\end{array}$ & $\begin{array}{l}17 \\
15 \\
18 \\
15 \\
15\end{array}$ & $\begin{array}{l}0.02 \\
0.01 \\
0.0004 \\
0.08 \\
0.41\end{array}$ & $\begin{array}{l}+ \\
+ \\
+ \\
+ \\
+\end{array}$ \\
\hline Stenonema & $\begin{array}{l}\text { CIC Vs. EIC } \\
\text { CIL VS. EIL } \\
\text { C2R VS. E2R } \\
\text { CIR VS. EIR } \\
\text { E2L vs. E2E }\end{array}$ & $\begin{array}{r}12 \\
11 \\
13 \\
11 \\
5\end{array}$ & $\begin{array}{l}0.16 \\
0.37 \\
0.14 \\
0.01 \\
0.22\end{array}$ & $\begin{array}{l}+ \\
- \\
- \\
+ \\
+\end{array}$ & $\begin{array}{r}5 \\
5 \\
10 \\
5 \\
8\end{array}$ & $\begin{array}{l}0.29 \\
0.36 \\
0.41 \\
0.18 \\
0.26\end{array}$ & $\begin{array}{l}- \\
+ \\
- \\
+ \\
+\end{array}$ & $\begin{array}{l}17 \\
16 \\
23 \\
16 \\
13\end{array}$ & $\begin{array}{l}0.43 \\
0.69 \\
0.12 \\
0.003 \\
0.09\end{array}$ & $\begin{array}{l}+ \\
- \\
+ \\
-\end{array}$ \\
\hline $\begin{array}{l}\text { Blackflies } \\
\text { Simulidae }\end{array}$ & $\begin{array}{l}\text { CIC vs. EIC } \\
\text { CIL VS. EIL } \\
\text { C2R VS. E2R } \\
\text { CIR VS. EIR } \\
\text { E2L vs. E2E }\end{array}$ & $\begin{array}{r}12 \\
11 \\
9 \\
9 \\
8\end{array}$ & $\begin{array}{l}0.05 \\
0.72 \\
0.58 \\
0.11 \\
0.01\end{array}$ & $\begin{array}{l}+ \\
- \\
- \\
+\end{array}$ & $\begin{array}{l}5 \\
5 \\
6 \\
5 \\
5\end{array}$ & $\begin{array}{l}0.47 \\
0.42 \\
0.50 \\
0.72 \\
0.04\end{array}$ & $\begin{array}{l}- \\
- \\
- \\
+\end{array}$ & $\begin{array}{l}17 \\
16 \\
15 \\
14 \\
13\end{array}$ & $\begin{array}{l}0.21 \\
0.52 \\
0.40 \\
0.13 \\
0.002\end{array}$ & $\begin{array}{l}+ \\
- \\
- \\
+\end{array}$ \\
\hline $\begin{array}{l}\text { Midges } \\
\text { Chironomini }\end{array}$ & $\begin{array}{l}\text { CIC VS. EIC } \\
\text { CIL VS. EIL } \\
\text { C2R VS. E2R } \\
\text { CIR VS. EIR } \\
\text { E2L vs. E2E }\end{array}$ & $\begin{array}{r}12 \\
1 \\
7 \\
11 \\
10\end{array}$ & $\begin{array}{l}0.41 \\
0.42 \\
0.13 \\
0.93 \\
0.11\end{array}$ & $\begin{array}{l}+ \\
+ \\
+ \\
+ \\
+\end{array}$ & $\begin{array}{r}5 \\
5 \\
11 \\
5 \\
9\end{array}$ & $\begin{array}{l}0.69 \\
0.50 \\
0.72 \\
0.22 \\
0.16\end{array}$ & $\begin{array}{l}+ \\
+ \\
- \\
+ \\
+\end{array}$ & $\begin{array}{l}17 \\
16 \\
18 \\
16 \\
19\end{array}$ & $\begin{array}{l}0.34 \\
0.28 \\
0.41 \\
0.61 \\
0.03\end{array}$ & $\begin{array}{l}+ \\
+ \\
+ \\
+ \\
+\end{array}$ \\
\hline $\begin{array}{l}\text { Caddisflies } \\
\text { Hydropsyche and } \\
\text { Cheumatopsyche }\end{array}$ & $\begin{array}{l}\text { CIC vs. EIC } \\
\text { CIL VS. EIL } \\
\text { C2R vS. E2R } \\
\text { CIR VS. EIR } \\
\text { E2L vS. E2E }\end{array}$ & $\begin{array}{l}12 \\
11 \\
13 \\
11 \\
10\end{array}$ & $\begin{array}{l}0.21 \\
0.05 \\
0.81 \\
0.01 \\
0.01\end{array}$ & $\begin{array}{l}- \\
- \\
+\end{array}$ & $\begin{array}{l}5 \\
5 \\
7 \\
7 \\
8\end{array}$ & $\begin{array}{l}0.14 \\
0.08 \\
0.74 \\
0.02 \\
0.01\end{array}$ & $\begin{array}{l}- \\
- \\
- \\
+\end{array}$ & $\begin{array}{l}17 \\
16 \\
20 \\
18 \\
18\end{array}$ & $\begin{array}{l}0.07 \\
0.01 \\
0.74 \\
0.001 \\
0.0003\end{array}$ & $\begin{array}{l}- \\
- \\
- \\
+\end{array}$ \\
\hline
\end{tabular}

(7) "s" is the sign of the rank sum associated with the control group.

(2) "p" is the two tailed probability of the observed rank sum.

(3) Too few observations. 
TABLE 19. Comparison of Preoperational and Operational Macroinvertebrate Counts Using Wilcoxon's Signed-Ranks Test

\section{Macroinvertebrate Organism}

Number Significantly
Greater Numbers $(P<0.10)$ and Rema ined so During Operation

of Station Comparison
Significantly
Greater Numbers
$(P<0.10)$ but
Were Not so
During Operation D

(1)

Stenonema

Simulidae

Chironomini

Hydropsyche and

Cheumatopsyche

TOTAL

$$
2
$$

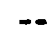

1

$--$

$\stackrel{1}{-1}$

4 Significantly
Lower Numbers
$(P<0.10)$ and

$(P<0.10)$ and
Remained so

Remained so

Significantly

Lower Numbers

$(P<0.10)$ but No

Were Not 50 Significant During Operation

Change

(1)

(1)

(1)

$$
2
$$

1

1

$--$

$=$

4
$-$

$-\infty$

$-$

$-$

$\underline{2}$

2
(1)

1

4

3

5

(1) Not enough data during operation.

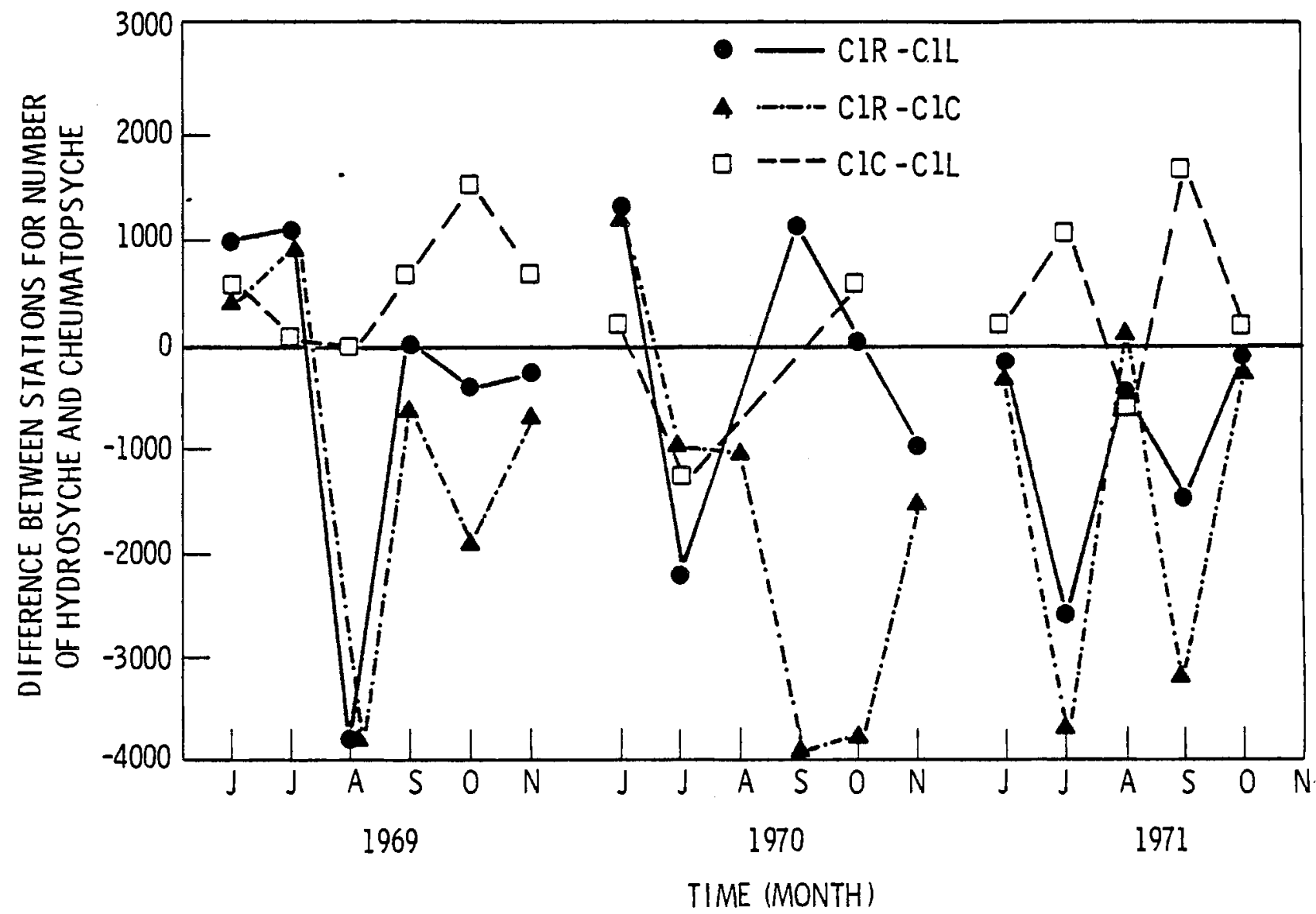

FIGURE 30. Illustration of Statistically Significant Differences Among Control Stations for Hydropsyche and Cheumatopsyche 
Both because of 1 imited numbers of observations available during the operational period (Table 18) and because we could not assess the magnitude of station differences by the Wilcoxon test used, the conclusion above is considered tentative. For example, even though we showed that the preoperational Baetis population was significantly $(P<0.01)$ higher at $C 2 R$ compared to $E 2 R$ (Table 18) and that it remained significantly higher during reactor operation, the counts from C2R might be for example, twice as numerous as those at E2R preoperationally, in contrast to say four times higher during operational periods.

Analys is of Benthos Station Ratios

Eberhardt (1976) has proposed a pseudodesign in which preoperational data on a site and a control area are compared to operational data on both areas, thus allowing replication in time to substitute for replication in space. In order to take advantage of such replication and to provide a means to circumvent the objection in the section above, we have calculated the ratios of stations (selected as discussed in the section above) where nonzero values occurred at both stations. The calculated ratios appear in Appendix $D$ along with a stem and leaf display (Tukey, 1976) for each organism. A key to the nomenclature of stem and leaf displays is found on page 2 of Appendix D. Clearly, on the arithmetic scale observations are skewed toward the origin. Further, it appears that Hydropsyche and Cheumatopsyche exhibit the largest ratios. However, when the same data are presented as logarithms (Appendix D) the distributions become much more symmetric and seem to contain fewer "outliers". Thus, it appears that a logarithmic transformation of benthos count ratios can be supported visually as well as theoretically (i.e., the distribution of the ratio of two lognormally distributed random variables should also be lognormal). Some further discussion of ratios with reference to radionuclides is in Thomas, et al. (1976) while the book by Chayes (1971) offers some additional ideas when correlations are present. 
The results of an individual one-way analysis of variance (ANOVA) for each control/site station ratio, where each year is considered a treatment, are in Table 20. The ratio of Simulidae counted at stations E2L and E2E were significantly different $(P<0.05)$ in operational year 1971 compared to the two preoperational years $(1969,1970)$. We believe the wide difference in mean ratios for Simulidae (Table 20) is reflected in the discrepant variance calculated for this organism in Table 15. No other statistically significant results are formed in Table 20 and thus no evidence for a change due to operation of Monticello is provided. Finally, we have plotted (Figure 31) the entire data set for all five station ratios by times observed using the family simulidae to assess possible seasonal (or monthly) effects and to visually appraise the possibility that we could increase the discriminatory ability (power) of our test by comparing all preoperational to operational station ratios. Even though nearly twice as many operational ratios are less than unity ( 8 versus 5 ) while the preoperational ratios are almost evenly divided (29 versus 22), it would require a large number of additional samples to discriminate between the two periods. Even if a statistically significant difference could be detected, it appears from the figure that the resuit would probably be ecologically meaningless because the prospective difference would be numerically very small.

Table 22 was prepared to circumvent any influence that season-of-theyear (month) might exert (by inflating estimates of error variance in the one-way ANOVAS above) and to avoid the problems inherent in an unbalanced analysis of variance generaliy. In Table 22, the mean of 1969 and 1970 preoperational ratios were compared to the mean of the 1971 and 1972 station operational ratio for each month (if one observation was available it was used as a mean value). We then calculated the algebraic sign of the mean preoperational-operational value and reported the summary in Table 22. There was a nearly equal distribution of positive and negative signs, again supporting the conclusion of no significant changes in the benthic community resulting from the operation of the Monticello plant. 
TABLE 20. Results of Macroinvertebrate One-Way Analysis of Variance for Logarithms (Base 10) of Control/ Site Station Ratios Where Years are Treatments

\begin{tabular}{|c|c|c|c|c|c|c|c|c|}
\hline \multirow[b]{2}{*}{ Organism } & \multirow[b]{2}{*}{$\begin{array}{c}\text { Years } \\
\text { Observed }\end{array}$} & \multirow[b]{2}{*}{$\begin{array}{l}\text { Number } \\
\text { of Ratios }\end{array}$} & \multirow[b]{2}{*}{$\begin{array}{c}F \\
\text { Value }\end{array}$} & \multirow[b]{2}{*}{ Probability } & \multicolumn{4}{|c|}{ Range of Yearly Means } \\
\hline & & & & & \multicolumn{2}{|c|}{$\frac{\log 10}{\text { Minimum to Maximum }}$} & \multicolumn{2}{|c|}{$\frac{\text { Antilog }}{\text { Minimum to Maximum }}$} \\
\hline & & & & IC/EIC- & & & & \\
\hline \multirow{2}{*}{$\begin{array}{l}\text { Macronemum } \\
\text { Baetis } \\
\text { Stenonema } \\
\text { Simul idae } \\
\text { Chironomini } \\
\text { Hydropsyche and } \\
\text { Cheuma topsyche }\end{array}$} & $\begin{array}{l}1969-1971 \\
1969-1971 \\
1969-1971 \\
1969-1971 \\
1969-1971\end{array}$ & $\begin{array}{l}10 \\
16 \\
16 \\
17 \\
17\end{array}$ & $\begin{array}{l}2.34 \\
1.30 \\
0.84 \\
1.15 \\
0.76\end{array}$ & $\begin{array}{l}0.16 \\
0.31 \\
0.45 \\
0.35 \\
0.93\end{array}$ & $\begin{array}{r}-0.463 \\
0.157 \\
-0.005 \\
-0.214 \\
0.079\end{array}$ & $\begin{array}{l}0.316 \\
0.592 \\
0.302 \\
0.392 \\
0.147\end{array}$ & $\begin{array}{l}0.344 \\
1.435 \\
0.989 \\
0.611 \\
1.198\end{array}$ & $\begin{array}{l}2.070 \\
3.910 \\
2.000 \\
2.470 \\
1.401\end{array}$ \\
\hline & 1969-1971 & 17 & 0.81 & 0.46 & -0.196 & -0.031 & 0.637 & 0.932 \\
\hline \multirow{3}{*}{$\begin{array}{l}\text { Macronemum } \\
\text { Baetis } \\
\text { Stenonema } \\
\text { Simul idae } \\
\text { Chironomini } \\
\text { Hydropsyche and } \\
\text { Cheuma topsyche }\end{array}$} & $\begin{array}{l}1969-1971 \\
1969-1971 \\
1969-1971 \\
1969-1971 \\
1969-1971\end{array}$ & $\begin{array}{r}9 \\
14 \\
16 \\
15 \\
16\end{array}$ & $\begin{array}{l} \\
0.40 \\
1.30 \\
1.74 \\
0.16 \\
0.28\end{array}$ & $\begin{array}{l}0.69 \\
0.31 \\
0.22 \\
0.85 \\
0.76\end{array}$ & $\begin{array}{r}-0.280 \\
0.137 \\
-0.330 \\
-0.209 \\
0.051\end{array}$ & $\begin{array}{r}0.163 \\
0.451 \\
0.258 \\
-0.042 \\
0.183\end{array}$ & $\begin{array}{l}0.524 \\
1.370 \\
0.468 \\
0.617 \\
1.150\end{array}$ & $\begin{array}{l}1.040 \\
2.830 \\
1.810 \\
0.908 \\
1.520\end{array}$ \\
\hline & 1969-197 & 16 & 0.38 & 0.69 & -0.346 & -0.198 & 0.451 & 0.634 \\
\hline & & & \multicolumn{2}{|c|}{$\longrightarrow$ C2R/E2R- } & & & & \\
\hline \multirow{3}{*}{$\begin{array}{l}\text { Macronemum } \\
\text { Baetis } \\
\text { Stenonema } \\
\text { Simul idae } \\
\text { Chironomini } \\
\text { Hydropsyche and } \\
\text { Cheuma topsyche }\end{array}$} & $\begin{array}{l}1969-1971 \\
1969-1972 \\
1969-1972 \\
1969-1971 \\
1969-1972\end{array}$ & $\begin{array}{l}11 \\
17 \\
21 \\
12 \\
17\end{array}$ & $\begin{array}{l}1.72 \\
0.90 \\
1.08 \\
0.03 \\
0.26\end{array}$ & $\begin{array}{l}0.24 \\
0.47 \\
0.39 \\
0.97 \\
0.85\end{array}$ & $\begin{array}{r}-0.190 \\
0.310 \\
-0.292 \\
-0.521 \\
-0.087\end{array}$ & $\begin{array}{r}0.535 \\
0.764 \\
0.151 \\
-0.205 \\
0.171\end{array}$ & $\begin{array}{l}0.644 \\
2.040 \\
0.511 \\
0.301 \\
0.819\end{array}$ & $\begin{array}{l}3.420 \\
5.800 \\
1.410 \\
0.624 \\
0.674\end{array}$ \\
\hline & $1969-1971$ & 20 & 0.08 & 0.93 & -0.166 & -0.054 & 0.682 & 0.883 \\
\hline & & & \multicolumn{2}{|c|}{$\longrightarrow$ CIR/EIR—- } & & & & \\
\hline \multirow{3}{*}{$\begin{array}{l}\text { Macronemum } \\
\text { Baetis } \\
\text { Stenonema } \\
\text { Simulidae } \\
\text { Chironomini } \\
\text { Hydropsyche and } \\
\text { Cheuma topsyche }\end{array}$} & $\begin{array}{l}1969-1971 \\
1969-1971 \\
1969-1971 \\
1969-1971 \\
1969-1971\end{array}$ & $\begin{array}{l}7 \\
14 \\
15 \\
12 \\
16\end{array}$ & $\begin{array}{l}0.15 \\
0.15 \\
0.04 \\
1.73 \\
1.04\end{array}$ & $\begin{array}{l}0.86 \\
0.86 \\
0.97 \\
0.23 \\
0.38\end{array}$ & $\begin{array}{c}-0.778 \\
0.0846 \\
0.3533 \\
-1.019 \\
-0.0515\end{array}$ & $\begin{array}{r}-0.583 \\
0.212 \\
0.410 \\
-0.098 \\
0.198\end{array}$ & $\begin{array}{l}0.166 \\
1.215 \\
2.256 \\
0.096 \\
0.888\end{array}$ & $\begin{array}{l}0.279 \\
1.639 \\
2.570 \\
0.798 \\
1.576\end{array}$ \\
\hline & 1969-1972 & 18 & 0.70 & 0.57 & -0.4856 & -0.196 & 0.326 & 0.637 \\
\hline & & & \multicolumn{2}{|c|}{ E2L/E2E } & & & & \\
\hline \multirow{2}{*}{$\begin{array}{l}\text { Macronemum } \\
\text { Baetis } \\
\text { Stenonema } \\
\text { Simul idae (1) } \\
\text { Chironomini } \\
\text { Hydropsyche and } \\
\text { Cheuma topsyche }\end{array}$} & $\begin{array}{l}1969-1972 \\
1969-1972 \\
1970-1972 \\
1969-1971 \\
1969-1972\end{array}$ & $\begin{array}{r}9 \\
14 \\
11 \\
8 \\
18\end{array}$ & $\begin{array}{l}0.19 \\
0.08 \\
0.61 \\
6.99 \\
0.54\end{array}$ & $\begin{array}{l}0.90 \\
0.97 \\
0.57 \\
0.04 \\
0.66\end{array}$ & $\begin{array}{l}0.439 \\
0.109 \\
0.088 \\
0.540 \\
0.043\end{array}$ & $\begin{array}{l}0.802 \\
0.493 \\
0.328 \\
1.381 \\
0.390\end{array}$ & $\begin{array}{l}2.750 \\
1.290 \\
1.230 \\
3.470 \\
1.100\end{array}$ & $\begin{array}{r}6.310 \\
3.110 \\
2.130 \\
24.050 \\
2.470\end{array}$ \\
\hline & $1969-1972$ & 18 & 1.68 & 0.22 & 0.212 & 1.057 & 1.620 & 11.220 \\
\hline
\end{tabular}

(1) Note the wide range of mean ratios on arithmetic scale. This may partially explain the large variance in Table 9. 


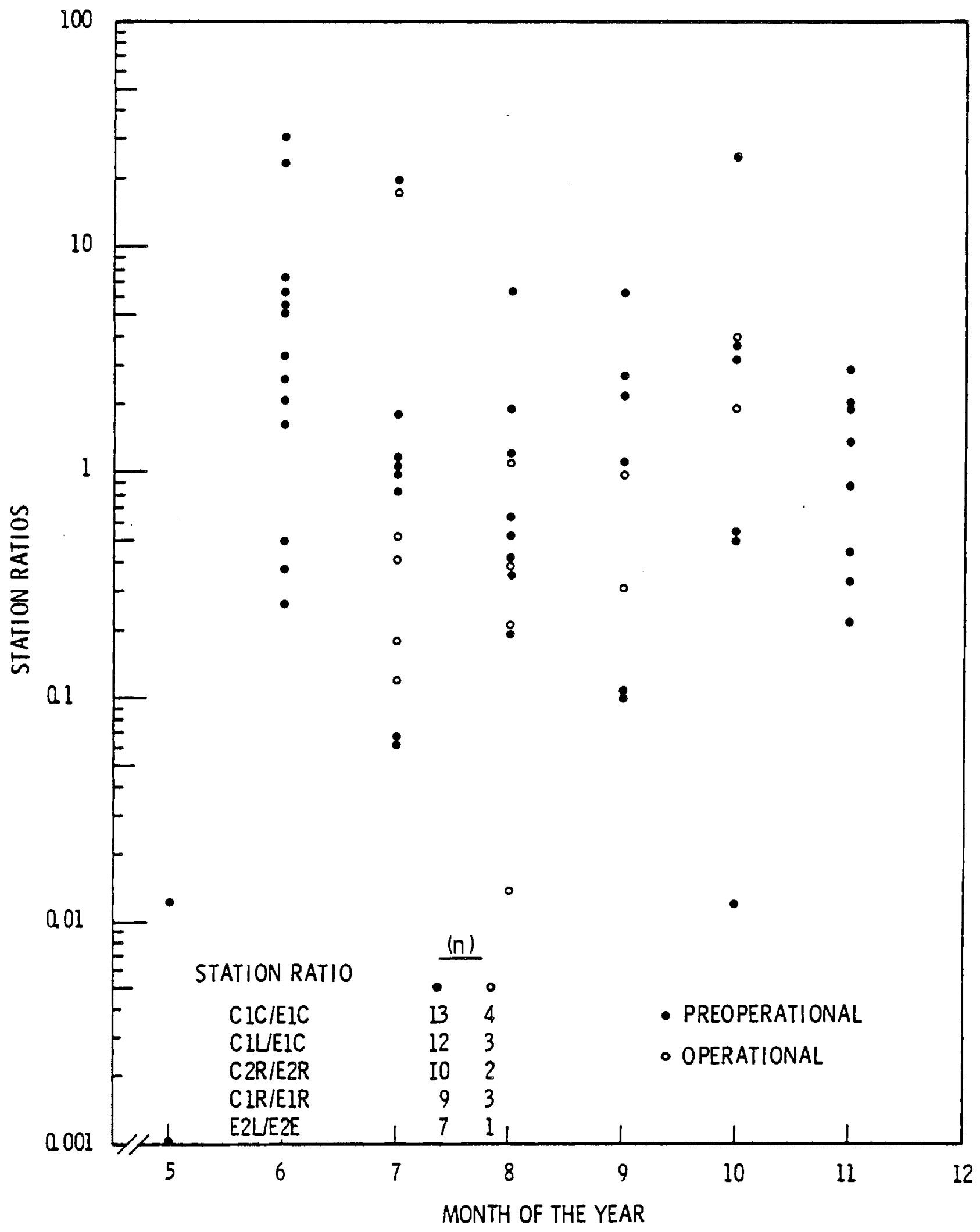

FIGURE 31. Time Series of Station Ratios for Simulidae 
TABLE 21. Comparison of Station Logarithmic Count Ratios by Month for Preoperational and Operational Years

\begin{tabular}{|c|c|c|c|c|c|c|c|c|c|c|c|}
\hline \multirow[b]{2}{*}{$\begin{array}{l}\text { Station } \\
\text { Ratio } \\
\end{array}$} & \multirow[b]{2}{*}{ Month } & \multicolumn{5}{|c|}{ Macronemum } & \multicolumn{5}{|c|}{ Baetis } \\
\hline & & \multicolumn{2}{|c|}{$\begin{array}{l}\text { Preoperational } \\
1969 \quad 1970\end{array}$} & \multicolumn{2}{|c|}{$\begin{array}{l}\text { Operationa 1 } \\
1971 \quad 1972 \\
\end{array}$} & $\begin{array}{l}\text { Average of } \\
1971 \text { and } 1972 \\
\text { Relative to } \\
1969 \text { and } 1970 \\
\end{array}$ & \multicolumn{2}{|c|}{$\frac{\text { Preoperational }}{1969}$} & \multicolumn{2}{|c|}{ Operational } & $\begin{array}{l}\text { Average of } \\
1971 \text { and } 1972 \\
\text { Relative to } \\
1969 \text { and } 1970 \\
\end{array}$ \\
\hline \multirow[t]{7}{*}{ CIC/EIC } & 5 & 0.12 & -.385 & & & & & & & & \\
\hline & 6 & & -.602 & -.778 & & - & .829 & .257 & 1.501 & & + \\
\hline & 7 & & & & & & .240 & .092 & 1.161 & & + \\
\hline & 8 & .429 & -.176 & -.954 & & - & .239 & -.129 & -.078 & & - \\
\hline & 9 & .506 & .182 & .342 & & - & .196 & .448 & .384 & & + \\
\hline & 10 & & & & & & & .280 & -.010 & & - \\
\hline & 11 & & & & & & & & & & \\
\hline \multirow[t]{7}{*}{ CIL/EIL } & 5 & & & & & & & & & & \\
\hline & 6 & -1.494 & -.602 & & & & .771 & .407 & .444 & & - \\
\hline & 7 & & -.176 & -.398 & & - & .574 & .358 & .621 & & + \\
\hline & 8 & .139 & & .410 & & + & .362 & & .402 & & + \\
\hline & 9 & .514 & -.041 & .477 & & + & & -.231 & .488 & & + \\
\hline & 10 & & & & & & -.164 & .012 & .301 & & + \\
\hline & 11 & & & & & & & & & & 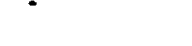 \\
\hline \multirow[t]{7}{*}{ C2R/E2R } & 5 & .439 & & & & & & & & & \\
\hline & 6 & .133 & .342 & & & & .596 & .580 & .107 & .368 & - \\
\hline & 7 & 1.380 & .301 & .097 & & - & .114 & -.170 & .439 & & + \\
\hline & 8 & .301 & .114 & -.477 & & - & .074 & .536 & .232 & & - \\
\hline & 9 & .419 & 1.279 & & & & .378 & .702 & .597 & & + \\
\hline & 10 & & & & & & .449 & 2.170 & .176 & 903 & - \\
\hline & 11 & & & & & & & & & & \\
\hline \multirow[t]{7}{*}{ CIR/EIR } & 5 & & & & & & & & & & \\
\hline & 6 & & & & & & & .743 & -.197 & & - \\
\hline & 7 & & & -.176 & & & .361 & .359 & .859 & & + \\
\hline & 8 & -.504 & -.267 & -1.255 & & - & .274 & .294 & .044 & & $\cdot$ \\
\hline & 9 & -.602 & -.978 & -.903 & & - & .275 & -.102 & -.232 & & - \\
\hline & 10 & & & & & & -.182 & -.234 & -.051 & & + \\
\hline & 11 & & & & & & & & & & \\
\hline \multirow[t]{7}{*}{ E2L/E2E } & 5 & & & & & & & & & & \\
\hline & 6 & & .348 & & .602 & + & & -.454 & -.510 & .109 & + \\
\hline & 7 & & -.602 & .903 & & + & & -.331 & -.557 & & - \\
\hline & 8 & .359 & .727 & .681 & & + & -.101 & .180 & .646 & & + \\
\hline & 9 & 1.246 & 1.283 & & & & .496 & 1.437 & .778 & & - \\
\hline & 10 & & & & & & .836 & 1.635 & 1.1969 & & - \\
\hline & 11 & & & & & & & & & & \\
\hline
\end{tabular}




\section{TABLE 21. Continued}

\begin{tabular}{|c|c|c|c|c|c|c|c|c|c|c|}
\hline \multirow[b]{2}{*}{$\begin{array}{l}\text { Station } \\
\text { Ratio } \\
\end{array}$} & \multirow[b]{2}{*}{ Month } & \multicolumn{5}{|c|}{ Stenonema } & \multicolumn{4}{|c|}{ Simulidae } \\
\hline & & \multicolumn{2}{|c|}{$\begin{array}{l}\text { Preoperational } \\
1969 \quad 1970 \\
\end{array}$} & \multicolumn{2}{|c|}{$\begin{array}{l}\text { Operational } \\
1971 \quad 1972 \\
\end{array}$} & $\begin{array}{l}\text { Average of } \\
1971 \text { and } 1972 \\
\text { Relative to } \\
1969 \text { and } 1970 \\
\end{array}$ & \multicolumn{2}{|c|}{$\frac{\text { Preoperational }}{1969} \frac{1970}{199}$} & \multirow[t]{2}{*}{$\begin{array}{l}\text { Operational } \\
1971 \quad 1972\end{array}$} & $\begin{array}{l}\text { Average of } \\
1971 \text { and } 1972 \\
\text { Relative to } \\
1969 \text { and } 1970 \\
\end{array}$ \\
\hline \multirow[t]{7}{*}{ CIC/EIC } & 5 & & & & & & & & & \\
\hline & 6 & .778 & -.243 & .602 & & + & 1.370 & .529 & .417 & - \\
\hline & 7 & .426 & -.398 & & & + & .027 & -1.169 & -.729 & - \\
\hline & 8 & & -.176 & -.602 & & - & .084 & -.267 & -1.358 & - \\
\hline & 9 & .033 & .138 & -.022 & & - & .342 & .434 & .000 & - \\
\hline & 10 & .153 & -.151 & & & - & .574 & .509 & .602 & + \\
\hline & 11 & & .954 & & & & -.043 & .145 & & \\
\hline \multirow[t]{7}{*}{ CIL/EIL } & 5 & & . & & & & & & & \\
\hline & 6 & 1.279 & -.602 & .176 & & - & .848 & .742 & .219 & - \\
\hline & 7 & .929 & -.564 & .269 & & - & .080 & -.079 & -.360 & - \\
\hline & 8 & -.022 & & & & + & -.178 & & -.371 & - \\
\hline & 9 & -.071 & -.417 & -.084 & & + & .051 & -.954 & & \\
\hline & 10 & .036 & .647 & .301 & & - & .398 & -.278 & .301 & + \\
\hline & 11 & -.602 & -.653 & & & & -.653 & -.477 & & \\
\hline \multirow[t]{8}{*}{$C 2 R / E 2 R$} & 2 & & -.477 & .349 & & + & & & & \\
\hline & 5 & .352 & & -.380 & & - & -4.000 & & -1.583 & + \\
\hline & 6 & .301 & .331 & .204 & & - & -.583 & .410 & .329 & + \\
\hline & 7 & -.041 & -.028 & -.222 & & - & .266 & .000 & -.903 & - \\
\hline & 8 & -.176 & -.681 & -.602 & & - & -.383 & & .073 & + \\
\hline & 9 & -.339 & -.456 & .439 & & + & & & & \\
\hline & 10 & -.176 & -.439 & -.067 & & + & 1.398 & & & \\
\hline & 11 & & & & & & .467 & & & \\
\hline \multirow[t]{7}{*}{ CIR/EIR } & 5 & & & & & & & & & \\
\hline & 6 & & .021 & .439 & & + & & -.298 & .422 & + \\
\hline & 7 & .125 & .760 & .882 & & + & 1.301 & -1.176 & -.283 & - \\
\hline & 8 & .176 & .352 & -.187 & & - & -.347 & -.699 & -.669 & - \\
\hline & 9 & .322 & .347 & .118 & & - & -1.000 & & -.505 & + \\
\hline & 10 & .865 & .128 & .769 & & + & & -1.903 & & \\
\hline & 11 & & .512 & & & & -.345 & & & \\
\hline \multirow[t]{7}{*}{ E2L/E2E } & 5 & & -.114 & -.125 & .090 & + & & & & \\
\hline & 6 & & .163 & .255 & & + & & .751 & 1.487 & + \\
\hline & 7 & & -.090 & -.021 & & + & & & 1.276 & \\
\hline & 8 & & .873 & .150 & & - & .820 & .301 & & \\
\hline & 9 & & .809 & .182 & & - & & .806 & & \\
\hline & 10 & & & & & & & & & \\
\hline & 11 & & & & & & .336 & .301 & & \\
\hline
\end{tabular}




\section{TABLE 21. Continued}

\begin{tabular}{|c|c|c|c|c|c|c|c|c|c|c|c|}
\hline \multirow[b]{2}{*}{$\begin{array}{l}\text { Station } \\
\text { Ratio } \\
\end{array}$} & \multirow[b]{2}{*}{ Month } & \multicolumn{5}{|c|}{ Chironomini } & \multicolumn{5}{|c|}{ Hydropsyche and Cheumatopsyche } \\
\hline & & \multicolumn{2}{|c|}{$\begin{array}{l}\text { Preoperational } \\
1969 \quad 1970\end{array}$} & \multicolumn{2}{|c|}{$\begin{array}{l}\text { Operational } \\
971 \quad 1972\end{array}$} & $\begin{array}{l}\text { Average of } \\
1971 \text { and } 1972 \\
\text { Relative to } \\
1969 \text { and } 1970 \\
\end{array}$ & \multicolumn{2}{|c|}{ Preoperational } & \multicolumn{2}{|c|}{ Operational } & $\begin{array}{l}\text { Average of } \\
1971 \text { and } 1972 \\
\text { Relative to } \\
1969 \text { and } 1970 \\
\end{array}$ \\
\hline \multirow[t]{6}{*}{ CIC/EIC } & 6 & .655 & .514 & .453 & & - & -.040 & -.395 & -.044 & & + \\
\hline & 7 & -.016 & -.224 & .193 & & + & -.060 & -.214 & .136 & & + \\
\hline & 8 & .167 & .161 & -.295 & & - & .019 & -.004 & -.326 & & - \\
\hline & 9 & .185 & .388 & -.038 & & - & -.178 & .123 & -.222 & & - \\
\hline & 10 & -.064 & .053 & .080 & & + & -.133 & .084 & -.524 & & - \\
\hline & 11 & -.267 & -.013 & & & & -.528 & .222 & & & \\
\hline \multirow[t]{6}{*}{ CIL/EIL } & 6 & .432 & .336 & .086 & & - & -.343 & -.561 & -.328 & & + \\
\hline & 7 & .170 & .043 & .854 & & + & .123 & -.142 & .092 & & + \\
\hline & 8 & .275 & -.081 & .284 & & + & .167 & & -.364 & & - \\
\hline & 9 & -.043 & .048 & -.149 & & - & -.195 & -.138 & -.602 & & - \\
\hline & 10 & -.218 & .028 & -.163 & & - & -.215 & -.631 & -.527 & & - \\
\hline & 11 & -.311 & & & & & -.727 & -.062 & & & \\
\hline \multirow[t]{8}{*}{ C2R/E2R } & 2 & & -.748 & -.669 & & + & & -1.843 & -1.289 & & + \\
\hline & 5 & & & .245 & & & .403 & & -.144 & & - \\
\hline & 6 & 171 & .234 & .253 & .043 & - & .185 & .027 & -.136 & & - \\
\hline & 7 & & .022 & .029 & & + & -.235 & -.197 & -.160 & & + \\
\hline & 8 & & .294 & -.052 & & - & .109 & -.049 & -.034 & & - \\
\hline & 9 & & .050 & -.243 & & - & -.127 & .469 & .444 & & + \\
\hline & 10 & & .178 & -.170 & .092 & - & -.233 & .604 & .157 & & - \\
\hline & 11 & & & & -.022 & & -.480 & & & & \\
\hline \multirow[t]{6}{*}{ CIR/EIR } & 6 & & .064 & .315 & & + & & -.378 & -.613 & -.261 & - \\
\hline & 7 & .569 & .053 & .611 & & + & .102 & -.295 & -.139 & & - \\
\hline & 8 & -.267 & .107 & -.088 & & - & -.362 & -.113 & -.372 & & - \\
\hline & 9 & .065 & .138 & -.044 & & - & -.276 & -.529 & -.925 & & - \\
\hline & 10 & -.227 & -.245 & .194 & & + & -.345 & -.498 & -.378 & -.131 & + \\
\hline & 11 & -.397 & .062 & & & & -.823 & -.012 & & & \\
\hline \multirow[t]{6}{*}{ E2L/E2E } & 6 & & .240 & .429 & .481 & + & & -.015 & .258 & .373 & + \\
\hline & 7 & & .151 & .720 & & + & & .290 & .502 & & + \\
\hline & 8 & -.196 & .453 & .327 & & + & .519 & .735 & .758 & & + \\
\hline & 9 & .255 & 1.178 & .270 & & - & 1.272 & 1.598 & 1.853 & & + \\
\hline & 10 & .335 & .451 & -.314 & -.008 & - & 1.367 & 1.224 & 1.454 & .094 & - \\
\hline & 11 & .496 & -.132 & & -.345 & - & 1.072 & .785 & & .170 & - \\
\hline
\end{tabular}


TABLE 22. Comparison of Preoperational and Operationa] Logarithmic Macroinvertebrate Ratios

\begin{tabular}{|c|c|c|}
\hline \multirow[b]{2}{*}{ Organism } & \multicolumn{2}{|c|}{$\begin{array}{l}\text { Number of Times the Average } \\
\text { Logarithm of } 1971 \text { and } 1972 \\
\text { (Operational) Ratios Compared } \\
\text { to the Average of } 1969 \text { and } 1970 \\
\text { (Preoperational) Ratios Were: }\end{array}$} \\
\hline & Positive & Negative \\
\hline Macronemum & 5 & 8 \\
\hline Baetis & 11 & 13 \\
\hline Stenomena & 13 & 14 \\
\hline Simulidae & 8 & 10 \\
\hline Chironomini & 12 & 14 \\
\hline $\begin{array}{l}\text { Hydropsyche } \\
\text { Cheuma topsyche }\end{array}$ & 12 & 15 \\
\hline
\end{tabular}

Summary

We have subjected the benthic data available to us to statistical analysis from three separate perspectives. The results of an analysis of variance, Wilcoxon's Signed-Ranks Test, and a ratio evaluation indicate no significant changes in benthic fauna from the operation of the Monticello Power Station. If short-term changes, such as earlier emergence were present, our analysis did not detect these effects. 
PERIPHYTON

Introduction

Unlike the benthic data, very little preoperational periphyton count data were available. Thus, our comparisons among various periphyton species were based on counts from heated and control stations only during periods of reactor operation. Three such control and heated "matched" stations were defined by knutson (1973). Following his definitions, we refer, in this and the following section, to Stations 2, 7, and 9 as ambient or control stations and Stations 3,11 , and 6 as heated or plume stations. Further, in 1971 sampling was initiated at Station $3 \mathrm{~A}$, near the mouth of the discharge canal. Details of sampling station locations are in Figure 9. The complete data set for the stations discussed above, is listed by species, station, and time in Appendix E. In addition, a graphic depiction of tota 1 periphyton counts across time for each station is also in Appendix $E$.

Even though considerably more species were enumerated by the consultants for Northern States Power Company, counts were quantitatively evaluated for the 12 species listed in Appendix $E$ because they usually constituted the majority of organisms enumerated. Table 23 illustrates the apparent exceptions by showing data for three stations where the 12 selected species represented less than $75 \%$ of the total count [26 sampling times (Table 23) of the possible 46 sampling periods shown for total periphyton in Appendix E]. However, only on 12 sampling dates of the 26 listed, denoted by an $X$ in Table 23, were there large (arbitrarily greater than 15,000 organisms $/ \mathrm{cm}^{2}$ ) numbers of periphyton counted. Thus, in a few cases large numbers of "seasonal" periphytic organisms were observed (cf. data of Stations 3 and $6,10 / 2 / 74$, Table 23) at times when the 12 selected species were not as abundant. Table 24 shows that of the 26 occurrences when less than $75 \%$ of the total count was analyzed, 24 were in March-May or the early fall. Therefore, it is possible that in the analyses which follow failure to detect effects on excluded organisms which were abundant only during cooler periods of the year may have occurred. 
TABLE 23. Times When Less than $75 \%$ of the Total Periphyton Were Accounted for by the Twelve Species Considered

\begin{tabular}{|c|c|c|c|c|c|}
\hline Station & Date & $\begin{array}{l}\text { Total } 12 \\
\text { Species }\end{array}$ & $\begin{array}{c}\text { Total } \\
\text { Species }\end{array}$ & $\begin{array}{l}\text { Fraction } \\
\text { Counted }\end{array}$ & $\begin{array}{l}\text { Large }(1) \\
\text { Numbers } \\
\end{array}$ \\
\hline \multirow[t]{5}{*}{2} & $7 / 22 / 71$ & 421,437 & $1,050,021$ & 0.4014 & $x$ \\
\hline & $5 / 22 / 72$ & 4,670 & 12,754 & 0.3662 & \\
\hline & $10 / 26 / 73$ & 2,800 & 3,760 & 0.7447 & \\
\hline & $11 / 09 / 73$ & 120 & 240 & 0.5000 & \\
\hline & $5 / 22 / 74$ & 694,535 & $1,031,978$ & 0.6730 & $x$ \\
\hline \multirow[t]{11}{*}{3} & $10 / 28 / 71$ & 0 & 51,191 & 0 & $x$ \\
\hline & $5 / 22 / 72$ & 640 & 2,080 & 0.3077 & \\
\hline & $10 / 03 / 72$ & 2,600 & 4,620 & 0.5628 & \\
\hline & $10 / 17 / 72$ & 5,220 & 12,630 & 0.4133 & \\
\hline & $9 / 11 / 73$ & 6,020 & 8,060 & 0.7469 & \\
\hline & $9 / 25 / 73$ & 35,458 & 71,580 & 0.4954 & $x$ \\
\hline & $10 / 09 / 73$ & 11,120 & 18,080 & 0.6150 & \\
\hline & $11 / 09 / 73$ & 120 & 640 & 0.1875 & \\
\hline & $5 / 22 / 73$ & 355 & 533 & 0.6660 & \\
\hline & $9 / 19 / 74$ & 376,700 & 695,640 & 0.5415 & $x$ \\
\hline & $10 / 02 / 74$ & 95,840 & 176,432 & 0.5432 & $x$ \\
\hline \multirow[t]{10}{*}{6} & $10 / 28 / 71$ & 1,988 & 18,886 & 0.1053 & $x$ \\
\hline & $5 / 22 / 72$ & 300 & 1,200 & 0.2500 & \\
\hline & $10 / 17 / 72$ & 5,130 & 7,130 & 0.7195 & \\
\hline & $3 / 03 / 73$ & 867 & 1,467 & 0.5910 & \\
\hline & $5 / 22 / 73$ & 8,820 & 15,220 & 0.5795 & $x$ \\
\hline & $9 / 25 / 73$ & $38,160,540$ & $60,720,900$ & 0.6285 & $x$ \\
\hline & $11 / 09 / 73$ & 480 & 720 & 0.6667 & \\
\hline & $5 / 22 / 74$ & 1,106 & 1,636 & 0.6760 & \\
\hline & $10 / 02 / 74$ & 102,300 & $1,938,700$ & 0.0528 & $x$ \\
\hline & $10 / 16 / 74$ & 275,500 & 510,300 & 0.5399 & $x$ \\
\hline
\end{tabular}

$\sqrt{17} X_{X}=>15,000$ for all species 
TABLE 24. Periods of the Year When $75 \%$ or Less of the Total Periphyton Were Accounted for by the Twelve Species Considered

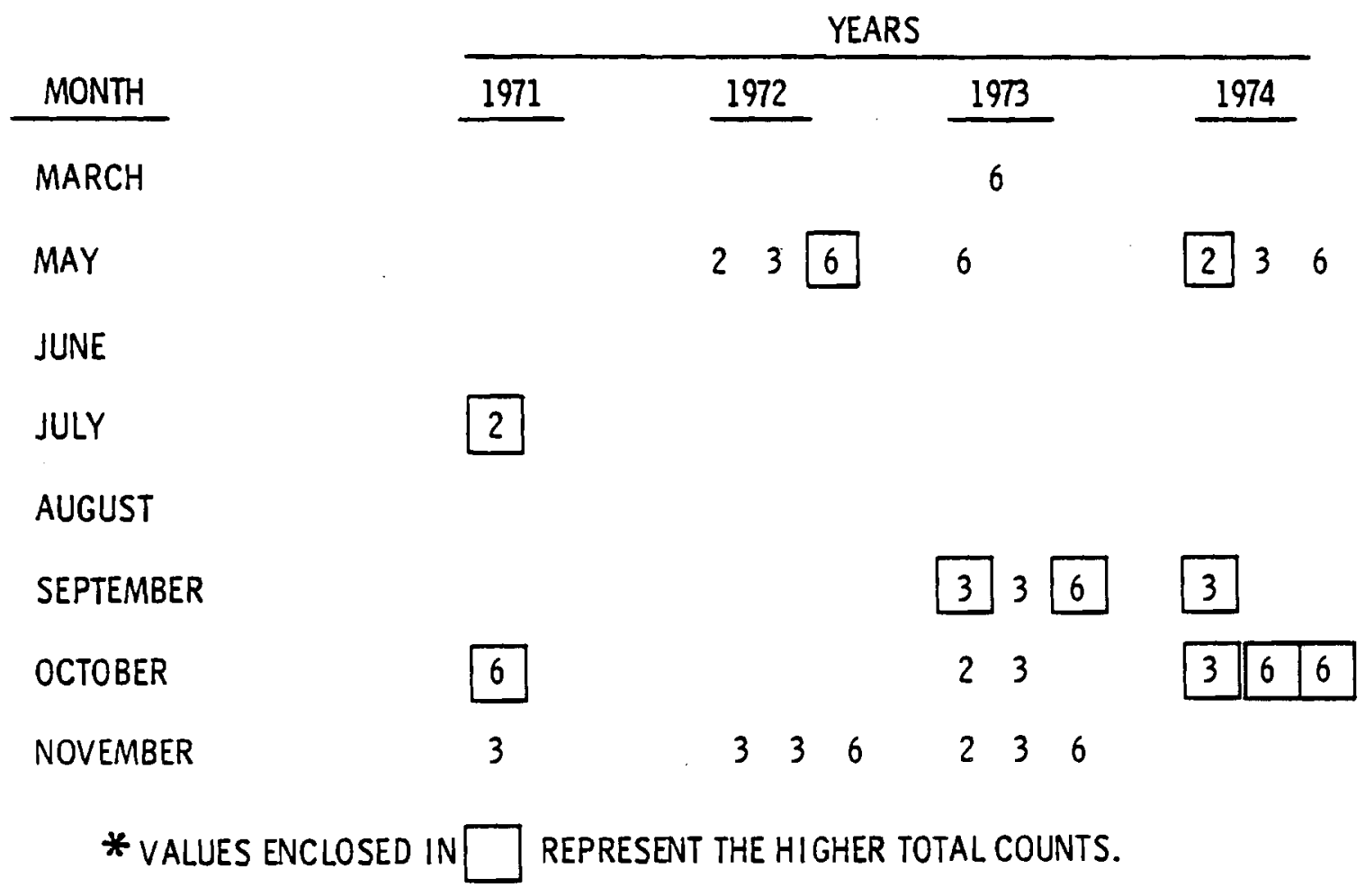


Wilcoxon's Signed-Ranks Test was used to statistically assess the 12 species for differences due to plant operation even though a significant finding might not be interpretable because no preoperational data were available (i.e., a control station may have a greater abundance of periphyton preoperationally than a counterpart heated station. This difference measured during operation may be attributed to the plant.) In addition, regression analyses of total periphyton counts using distance downstream from the discharge canal [Station 3A; Knutson (1973)] as the dependent variable were used to evaluate the operational data. The bases for using gradients of environmental insult in the analysis of environmental stressors are found in Thomas and Eberhardt (1975) and Eberhardt (1976).

Wilcoxon's Signed-Ranks Test

The three available heated versus control "matched" station comparisons evaluated using Wilcoxon's Signed-Ranks Test are given in Table 25 for the 12 selected species and for total counts of periphyton. A summary of these detailed results is in Table 26; two species were eliminated due to too few observations. All but two of the significant differences $(P<0.10$ was selected for exploratory purposes) involved the comparison of Stations 11 and 2. Control counts (Station 2) were higher in four of five cases illustrated (Table 26). In the absense of preoperational data we speculate that these results could be meaningless because the other two heated versus control comparisons did not exhibit similar significant effects. Further, Station 11 was located far downstream (5300 ft) from the discharge canal where diminished effects were anticipated. Thus, the results cannot be considered definitive in establishing any cause and effect relationship.

In order to evaluate the magnitude of the findings above, the time series of signed differences between numbers of periphyton enumerated at plume and control stations [where significant $(P<0.10)$ in Table 26] are tabulated in Table 27. In terms of large numbers of organisms counted, it appears that many more Cocconeis placentula were found at Station 2 than at Station 11 in the summer of 1973. Values for Chroococcus minimus at Station 9 exhibited a similar pattern but no other station's comparisons appeared as consistent or involved such large numbers of periphyton. In the absence of 
TABLE 25. Results of Wilcoxon's Signed-Ranks Test for Periphyton Numbers where Stations 3, 6, and 11 were Subjected to Thermal Additions

\begin{tabular}{|c|c|c|c|c|c|c|c|c|}
\hline Species & $\begin{array}{c}\text { Station } \\
\text { Comparisons } \\
\end{array}$ & $\begin{array}{l}\text { Total } \\
\text { Cases } \\
\end{array}$ & $\begin{array}{l}\text { Negati } \\
\text { Number }\end{array}$ & $\frac{\text { Rank }}{\text { Sum }}$ & & usitive & $\frac{\text { Rank }}{\text { Sum }}$ & $\begin{array}{c}\text { 2-Tailed } \\
\text { Probability }\end{array}$ \\
\hline $\begin{array}{l}\text { Total } \\
\text { All } \\
\text { Species }\end{array}$ & $\begin{array}{r}3 \text { vs. } 7 \\
6 \text { vs. } 9 \\
11 \text { vs. } 2\end{array}$ & $\begin{array}{l}38 \\
37 \\
34\end{array}$ & $\begin{array}{l}12 \\
20 \\
16\end{array}$ & $\begin{array}{l}348 \\
382 \\
301\end{array}$ & & $\begin{array}{l}23 \\
17 \\
18\end{array}$ & $\begin{array}{l}393 \\
321 \\
294\end{array}$ & $\begin{array}{l}0.74 \\
0.64 \\
0.95\end{array}$ \\
\hline $\begin{array}{l}\text { Chroococcus } \\
\text { minimis }\end{array}$ & $\begin{array}{r}3 \text { vs. } 7 \\
6 \text { vs. } 9 \\
11 \text { vs. } 2\end{array}$ & $\begin{array}{l}18 \\
22 \\
24\end{array}$ & $\begin{array}{r}5 \\
12 \\
12\end{array}$ & $\begin{array}{r}55 \\
148 \\
141\end{array}$ & & $\begin{array}{r}12 \\
7 \\
12\end{array}$ & $\begin{array}{r}98 \\
43 \\
159\end{array}$ & $\begin{array}{l}0.31 \\
0.04 \\
0.80\end{array}$ \\
\hline $\begin{array}{l}\text { Chroococcus } \\
\text { minor }\end{array}$ & $\begin{array}{r}3 \text { vs. } 7 \\
6 \text { vs. } 9 \\
17 \text { vs. } 2\end{array}$ & $\begin{array}{l}3 \\
1 \\
3\end{array}$ & 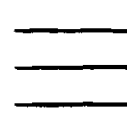 & $\begin{array}{l}\text { mited } \\
\text { mited } \\
\text { mited }\end{array}$ & $\begin{array}{l}\text { Data } \\
\text { Data } \\
\text { Data }\end{array}$ & $\begin{array}{l}\text { a Prec } \\
\text { a Prec } \\
\text { a Prec }\end{array}$ & $\begin{array}{l}\text { des } \mathrm{Ar} \\
\text { des } \mathrm{Ar} \\
\text { des } \mathrm{Ar}\end{array}$ & $\begin{array}{l}\text { lys is } \\
\text { llys is } \\
\text { llysis }\end{array}$ \\
\hline $\begin{array}{l}\text { Cocconeis } \\
\text { placentula }\end{array}$ & $\begin{array}{r}3 \text { vs. } 7 \\
6 \text { vs. } 9 \\
11 \text { vs. } 2\end{array}$ & $\begin{array}{l}29 \\
27 \\
29\end{array}$ & $\begin{array}{r}16 \\
9 \\
18\end{array}$ & $\begin{array}{l}232 \\
129 \\
298\end{array}$ & & $\begin{array}{l}10 \\
17 \\
11\end{array}$ & $\begin{array}{l}120 \\
222 \\
137\end{array}$ & $\begin{array}{l}0.16 \\
0.24 \\
0.08\end{array}$ \\
\hline $\begin{array}{l}\text { Achanthes } \\
\text { exigua }\end{array}$ & $\begin{array}{r}3 \text { vs. } 7 \\
6 \text { vs. } 9 \\
11 \text { vs. } 2\end{array}$ & $\begin{array}{l}2 \\
1 \\
0\end{array}$ & $\longrightarrow$ & $\begin{array}{l}\text { mited } \\
\text { mited } \\
\text { mited }\end{array}$ & $\begin{array}{l}\text { Data } \\
\text { Data } \\
\text { Data }\end{array}$ & $\begin{array}{l}\text { a Prec } \\
\text { a Prec } \\
\text { a Prec }\end{array}$ & $\begin{array}{l}\operatorname{des} A \\
\operatorname{des} A \\
\operatorname{des} A\end{array}$ & $\begin{array}{l}\text { liysis } \\
\text { ilysis } \\
\text { ilysis }\end{array}$ \\
\hline $\begin{array}{l}\text { Gomphonema } \\
\text { parvulum }\end{array}$ & $\begin{array}{r}3 \text { vs. } 7 \\
6 \text { vs. } 9 \\
11 \text { vs. } 2\end{array}$ & $\begin{array}{l}17 \\
14 \\
14\end{array}$ & $\begin{array}{l}8 \\
5 \\
5\end{array}$ & $\begin{array}{l}60 \\
33 \\
16\end{array}$ & & $\begin{array}{l}7 \\
8 \\
9\end{array}$ & $\begin{array}{l}60 \\
58 \\
62\end{array}$ & $\begin{array}{l}1.00 \\
0.38 \\
0.07\end{array}$ \\
\hline $\begin{array}{l}\text { Achanthes } \\
\text { lanceola ta }\end{array}$ & $\begin{array}{r}3 \text { vs. } 7 \\
6 \text { vs. } 9 \\
11 \text { vs. } 2\end{array}$ & $\begin{array}{r}6 \\
12 \\
6\end{array}$ & $\begin{array}{l}3 \\
7 \\
5\end{array}$ & $\begin{array}{r}7 \\
43 \\
19\end{array}$ & & $\begin{array}{l}7 \\
5 \\
1\end{array}$ & $\begin{array}{r}3 \\
35 \\
2\end{array}$ & $\begin{array}{l}0.47 \\
0.75 \\
0.08\end{array}$ \\
\hline $\begin{array}{l}\text { Cybella } \\
\text { as inuata }\end{array}$ & $\begin{array}{r}3 \text { vs. } 7 \\
6 \text { vs. } 9 \\
11 \text { vs. } 2\end{array}$ & $\begin{array}{r}31 \\
8 \\
6\end{array}$ & $\begin{array}{l}3 \\
5\end{array}$ & $\begin{array}{c}\text { mited } \\
7 \\
15\end{array}$ & Data & $\begin{array}{l}\text { Prec } \\
4 \\
0\end{array}$ & $\begin{array}{c}\operatorname{des} A r \\
21 \\
0\end{array}$ & $\begin{array}{r}\text { lysis } \\
0.24 \\
0.04\end{array}$ \\
\hline $\begin{array}{l}\text { Diatoma } \\
\text { vulgare }\end{array}$ & $\begin{array}{r}3 \text { vs. } 7 \\
6 \text { vs. } 9 \\
11 \text { vs. } 2\end{array}$ & $\begin{array}{l}10 \\
13 \\
15\end{array}$ & $\begin{array}{r}4 \\
9 \\
12\end{array}$ & $\begin{array}{r}18 \\
50 \\
100\end{array}$ & & $\begin{array}{l}5 \\
3 \\
3\end{array}$ & $\begin{array}{l}27 \\
28 \\
20\end{array}$ & $\begin{array}{l}0.59 \\
0.39 \\
0.02\end{array}$ \\
\hline $\begin{array}{l}\text { Gomphonema } \\
\text { ol ivacuim }\end{array}$ & $\begin{array}{r}3 \text { vs. } 7 \\
6 \text { vs. } 9 \\
11 \text { vs. } 2\end{array}$ & $\begin{array}{l}4 \\
5 \\
8\end{array}$ & 5 & $\begin{array}{c}\text { mited } \\
\text { mited } \\
18\end{array}$ & $\begin{array}{l}\text { Data } \\
\text { Data }\end{array}$ & $\begin{array}{l}\text { Prec } \\
\text { a Prec } \\
2\end{array}$ & $\begin{array}{l}\text { des } \mathrm{Ar} \\
\text { des } \mathrm{Ar} \\
10\end{array}$ & $\begin{array}{l}\text { Tysis } \\
\text { hysis } \\
0.50\end{array}$ \\
\hline $\begin{array}{l}\text { Navicula } \\
\text { gracilis }\end{array}$ & $\begin{array}{r}3 \text { vs. } 7 \\
6 \text { vs. } 9 \\
11 \text { vs. } 2\end{array}$ & $\begin{array}{r}9 \\
12 \\
17\end{array}$ & $\begin{array}{l}6 \\
4 \\
9\end{array}$ & $\begin{array}{l}28 \\
23 \\
83\end{array}$ & & $\begin{array}{l}3 \\
7 \\
7\end{array}$ & $\begin{array}{l}17 \\
43 \\
53\end{array}$ & $\begin{array}{l}0.52 \\
0.37 \\
0.44\end{array}$ \\
\hline $\begin{array}{l}\text { Navicula Cf. } \\
\text { rhynchocephaia }\end{array}$ & $\begin{array}{r}3 \text { vs. } 7 \\
6 \text { vs. } 9 \\
11 \text { vs. } 2\end{array}$ & $\begin{array}{l}11 \\
13 \\
14\end{array}$ & $\begin{array}{l}7 \\
4 \\
7\end{array}$ & $\begin{array}{l}39 \\
44 \\
40\end{array}$ & & $\begin{array}{l}2 \\
4 \\
4\end{array}$ & $\begin{array}{r}6 \\
22 \\
26\end{array}$ & $\begin{array}{l}0.05 \\
0.33 \\
0.53\end{array}$ \\
\hline $\begin{array}{l}\text { Synedra } \\
\text { ulna }\end{array}$ & $\begin{array}{r}3 \text { vs. } 7 \\
6 \text { vs. } 9 \\
11 \text { vs. } 2\end{array}$ & $\begin{array}{r}7 \\
15 \\
11\end{array}$ & $\begin{array}{l}4 \\
7 \\
7\end{array}$ & $\begin{array}{l}15 \\
66 \\
40\end{array}$ & & $\begin{array}{l}3 \\
7 \\
3\end{array}$ & $\begin{array}{l}13 \\
40 \\
15\end{array}$ & $\begin{array}{l}0.87 \\
0.41 \\
0.20\end{array}$ \\
\hline
\end{tabular}


preoperational data quantitative interpretation of the operational counts was not possible, and we were unable to qualitatively demonstrate any meaningful changes due to the operation of Monticello Power Plant (Table 27).

TABLE 26. Summary of Wilcoxon's Signed-Ranks

Tests for Periphyton Numbers

Species

Total all species

Chroococcus minimus

Cocconeis placentula

Gomphonema parvulum

Achanthes lanceolata

Cybella as inuata

Diatoma vulgare

Gomphonema olivacuim

Navicula gracilis

Navicula cf. rhynchocephala

Synedra ulna

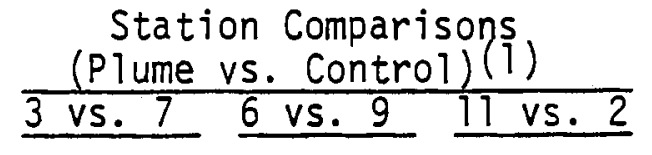

0.74

0.64

0.95

0.31

$0.04^{(2)} \mathrm{C}$

0.80

0.16

0.24

$0.08^{(2)} \mathrm{C}$

1.00

0.38

$0.07^{(2)_{P}}$

0.47

0.75

$0.08^{(2)} \mathrm{C}$

0.24

$0.04^{(2)} \mathrm{C}$

0.59

0.39

$0.02^{(2)} \mathrm{C}$

0.50

0.52

0.37

0.44

$0.05^{(2)} \mathrm{C}$

0.33

0.50

0.87

0.41

0.20

(1) Stations were matched on the basis of current and depth. Table values are two tailed probabilities of observing the rank sums in Table 26.

(2) Significant changes $(P<0.10)$ observed between test and control stations during reactor operation. Letter indicates whether control $(C)$ or plume $(P)$ organisms were more numerous. 
TABLE 27. Signed Differences in Periphyton Numbers (cells $/ \mathrm{cm}^{2}$ ) Between Control and Heated Periphyton Stations Found Significantly $(P<0.10)$ Different by Wilcoxon's Signed-Ranks Test

\begin{tabular}{|c|c|c|c|c|c|c|c|}
\hline \multirow[b]{2}{*}{ Data } & \multicolumn{5}{|c|}{ [Station $11-$ Station 2] } & \multirow[b]{2}{*}{$\frac{\text { [Station 3- Station 7] }}{\text { Navicula cf. rhynchocephala }}$} & \multirow[b]{2}{*}{$\frac{\text { [Station } 6 \text { - Station } 9}{\text { Chroococcus minimus }}$} \\
\hline & $\begin{array}{l}\text { Cocconeis } \\
\text { placentula }\end{array}$ & $\begin{array}{l}\text { Gomphonema } \\
\text { parvulum }\end{array}$ & $\begin{array}{l}\text { Achnanthes } \\
\text { lanceolata }\end{array}$ & $\begin{array}{l}\text { Cybella } \\
\text { asinuata }\end{array}$ & $\begin{array}{l}\text { Diatoma } \\
\text { vulgare }\end{array}$ & & \\
\hline $7 / 28 / 70$ & $+74,695$ & & & & & & \\
\hline $\begin{array}{l}7 / 22 / 71 \\
8 / 19 / 71\end{array}$ & $\begin{array}{l}+323,831 \\
+264,354\end{array}$ & & & & & & \\
\hline $\begin{array}{l}5 / 22 / 72 \\
6 / 05 / 72 \\
6 / 19 / 72 \\
7 / 04 / 72 \\
7 / 17 / 72 \\
7 / 31 / 72\end{array}$ & $\begin{array}{r}-3,887,600 \\
-5,630,452 \\
+1,500,004 \\
-12,853,792\end{array}$ & $\begin{array}{r}+5,600 \\
+23,058 \\
+58,791 \\
+610\end{array}$ & & $\begin{array}{r}-996 \\
-5,950 \\
-5,900\end{array}$ & -280 & & $\begin{array}{r}-521,740 \\
+70,678 \\
+200,912\end{array}$ \\
\hline $\begin{array}{r}9 / 01 / 72 \\
9 / 18 / 72 \\
10 / 03 / 72 \\
10 / 17 / 72 \\
11 / 01 / 72\end{array}$ & $\begin{array}{r}-7,534,880 \\
-22,450 \\
-14,900 \\
+980\end{array}$ & $\begin{array}{r}-664 \\
+21,208\end{array}$ & & & $\begin{array}{r}+100 \\
-14,300 \\
-1,200\end{array}$ & -430 & $\begin{array}{r}-2,831,524 \\
+2,200\end{array}$ \\
\hline $\begin{array}{l}4 / 24 / 73 \\
5 / 09 / 73 \\
5 / 22 / 73 \\
6 / 05 / 73\end{array}$ & $+59,000$ & $+35,000$ & & & $\begin{array}{r}-1,000 \\
-599,160 \\
-903,475 \\
-2,020\end{array}$ & $-1,280$ & $+76,000$ \\
\hline $\begin{array}{r}7 / 02 / 73 \\
7 / 17 / 73 \\
7 / 31 / 73 \\
2 / 14 / 73 \\
8 / 28 / 73 \\
9 / 11 / 73 \\
9 / 25 / 73 \\
10 / 09 / 73\end{array}$ & $\begin{array}{r}-7,500,000 \\
-7,000,000 \\
-7,000,000 \\
+8,000,000 \\
-2,000,000 \\
-3,000,000 \\
+20,600,000 \\
+20,000\end{array}$ & $\begin{array}{r}-4,299,760 \\
-80\end{array}$ & & $-6,180,000$ & $\begin{array}{r}-197,880 \\
+12,970\end{array}$ & $\begin{array}{r}-4,591,330 \\
-3,180\end{array}$ & $\begin{array}{r}-300,000 \\
-6,000,000 \\
+19,000,000 \\
-19,000,000 \\
-24,000,000\end{array}$ \\
\hline $\begin{array}{r}5 / 22 / 74 \\
6 / 10 / 74 \\
6 / 25 / 74 \\
7 / 09 / 74 \\
7 / 23 / 74 \\
8 / 05 / 74 \\
8 / 20 / 74 \\
9 / 04 / 74 \\
9 / 19 / 74 \\
10 / 02 / 74 \\
10 / 16 / 74 \\
11 / 03 / 74\end{array}$ & $\begin{array}{r}-18,488 \\
-4,160,000 \\
-183,672 \\
-367,344 \\
-61,200 \\
+20,400 \\
-69,000 \\
+95,200\end{array}$ & $\begin{array}{l}+343,536 \\
+292,518\end{array}$ & $\begin{array}{l}-41,430 \\
+17,006 \\
-45,920 \\
\\
-20,300 \\
\\
-60,000 \\
-17,000\end{array}$ & $-71,760$ & $\begin{array}{r}-54,300 \\
-135,900 \\
+206,040 \\
-15,300\end{array}$ & $\begin{array}{l}+6,700 \\
-13,500 \\
-26,500 \\
-91,800\end{array}$ & $\begin{array}{r}+63,360 \\
-2,877,520 \\
-688,770 \\
-12,478,000 \\
-2,230,400 \\
-455,600 \\
-2,040,000 \\
+764,900\end{array}$ \\
\hline
\end{tabular}

Regression Anatysis

The common logarithms of total periphyton are tabulated by year, seasonof-the-year (an arbitrary choice using 3-month periods) and distance from the discharge canal station in Appendix $F$. Examination of the mean values for increasing distances (parenthetical entries across the top of the tables) for both the summers of 1973 and 1974 indicated that regression analysis was a plausible analytical approach. Further, the summary for each year (at the bottom of each page in Appendix F) shows that the seasons (as defined) markedly differ in periphyton productivity, as expected, supporting a separate analysis for each season. In addition, it should be noted that 
the reactor was "off" prior to or during several sampling periods. Examination of the results from all stations during various on/off periods revealed no discernible effect which could be separated from natural variation and/or "real" changes on different sampling dates.

A summary of two regression models fitted to log transformed total counts using distance from the discharge canal station as the dependent variable, is shown in Table 28 . As illustrated by the calculated F-values, it would be difficult to choose between the linear and quadratic regression models when a significant $(P<0.05)$ relationship was found. It is clear that the counts from Station $3 A$ must be included for summer, fall and entire year regressions for 1974 to obtain significant model parameters $(P<0.05)$ because probabilities are no longer at the critical value when this data point is excluded. In contrast, the results for the summer and total year regressions in 1973 remained statistically significant $(P<0.05)$ when the results from $3 A$ were excluded, although the calculated $F$-values were smaller. Examples of the significant regression models are presented graphically in Figures 32-34 where the mean values for each station are plotted (Appendix F) rather than the individual data points used to fit the regressions. The 1972 linear regression relationship (fall, Figure 32) was statistically significant because of consistently small increases in counts with increasing distance from Station $3 \mathrm{~A}$. Clearly, the regression using a 11 the data for 1973 (Figure 33) is influenced mostly by summer and spring counts while the 1974 overall regression (Figure 34 ) is seemingly an average of all three seasons. 
TABLE 28. Summary of Regression Anatysis of Total Periphyton (cel1s $/ \mathrm{cm}^{2}$ ) with Distance (ft) from Monticel to Nuclear Power Plant

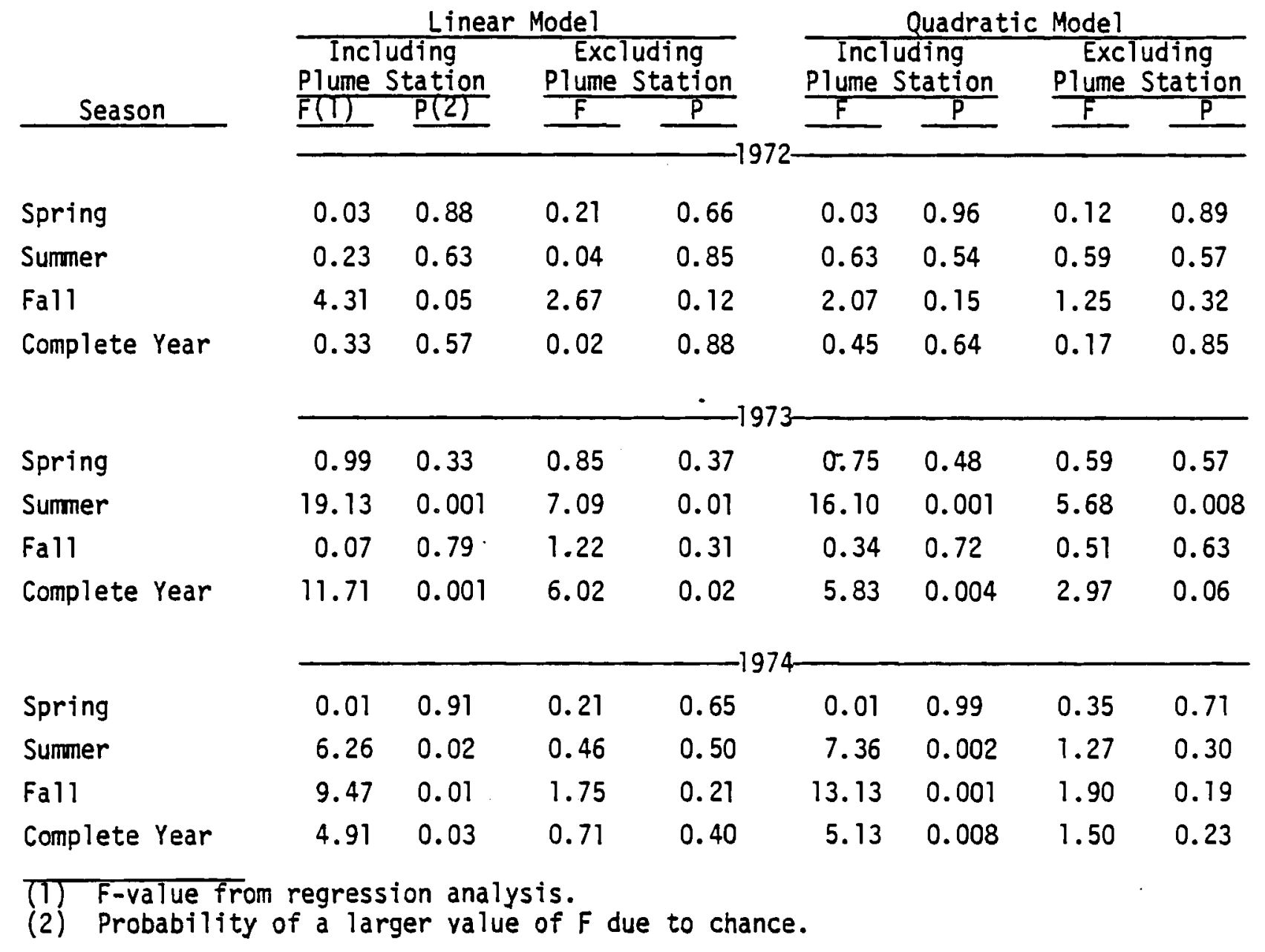




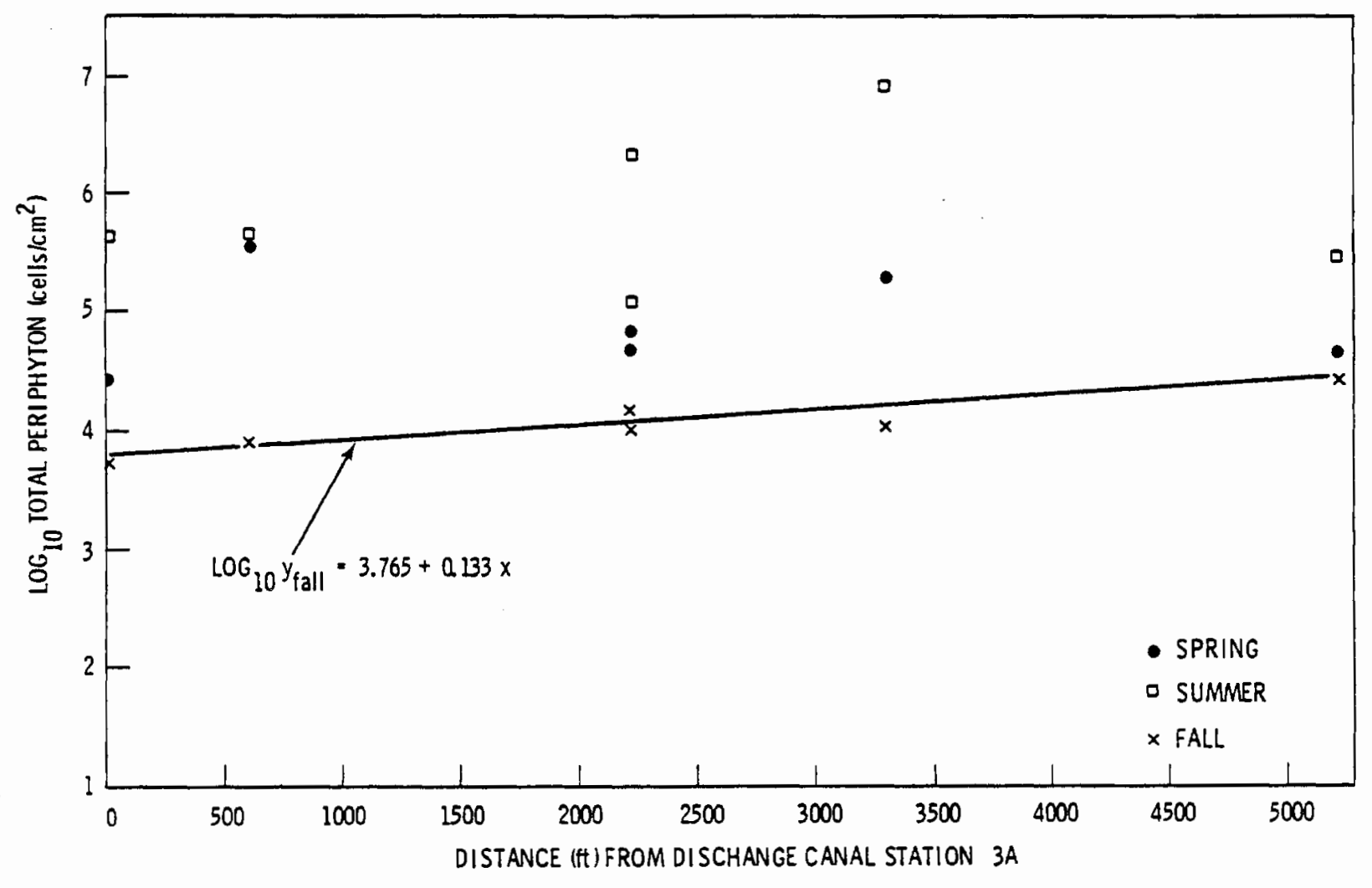

FIGURE 32. Total Periphyton $\left(\log _{10}\right)$ with Distance from Canal station 3 A for $1972\left(\mathrm{cells} / \mathrm{cm}^{2}\right)$ 


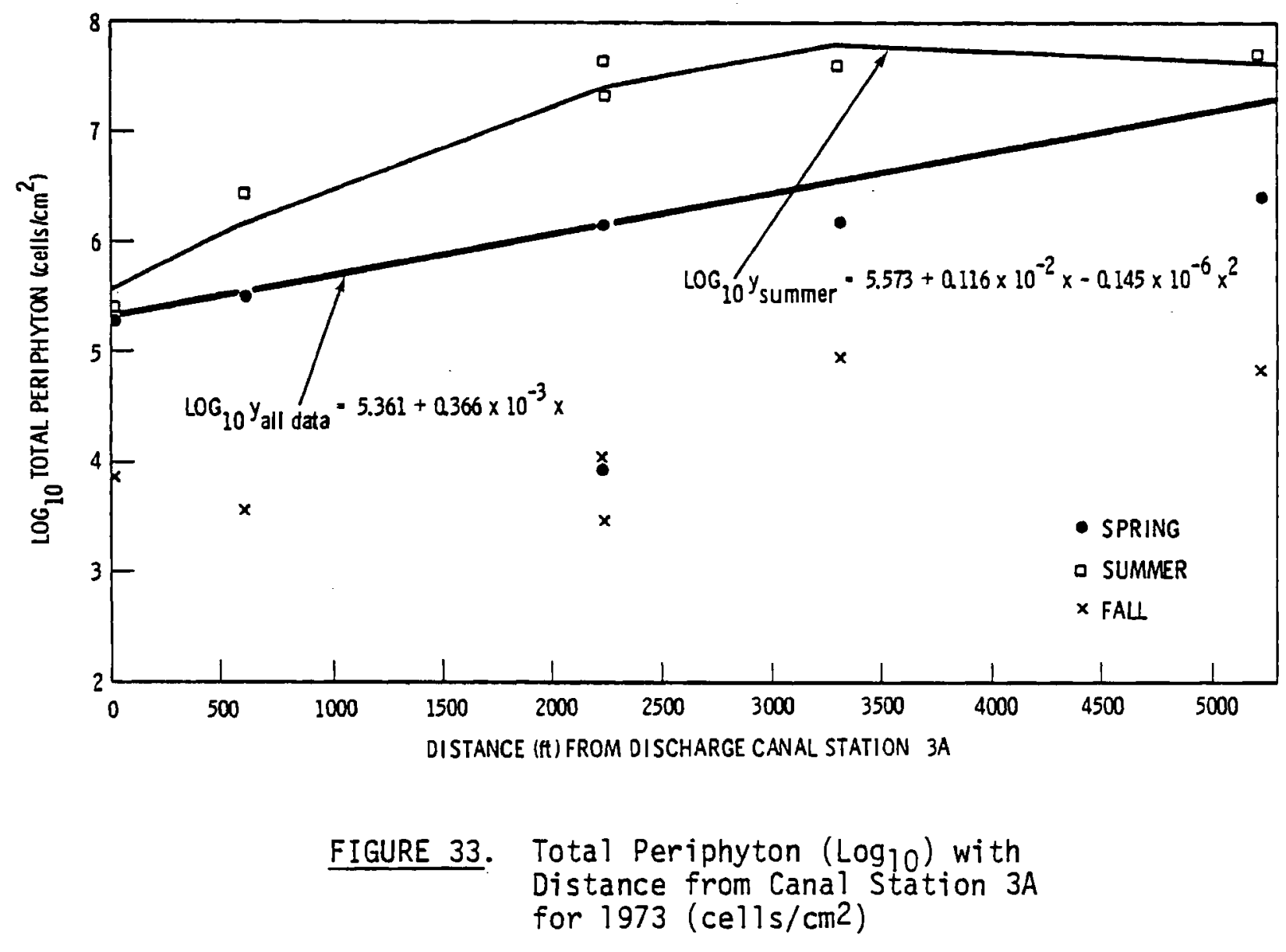




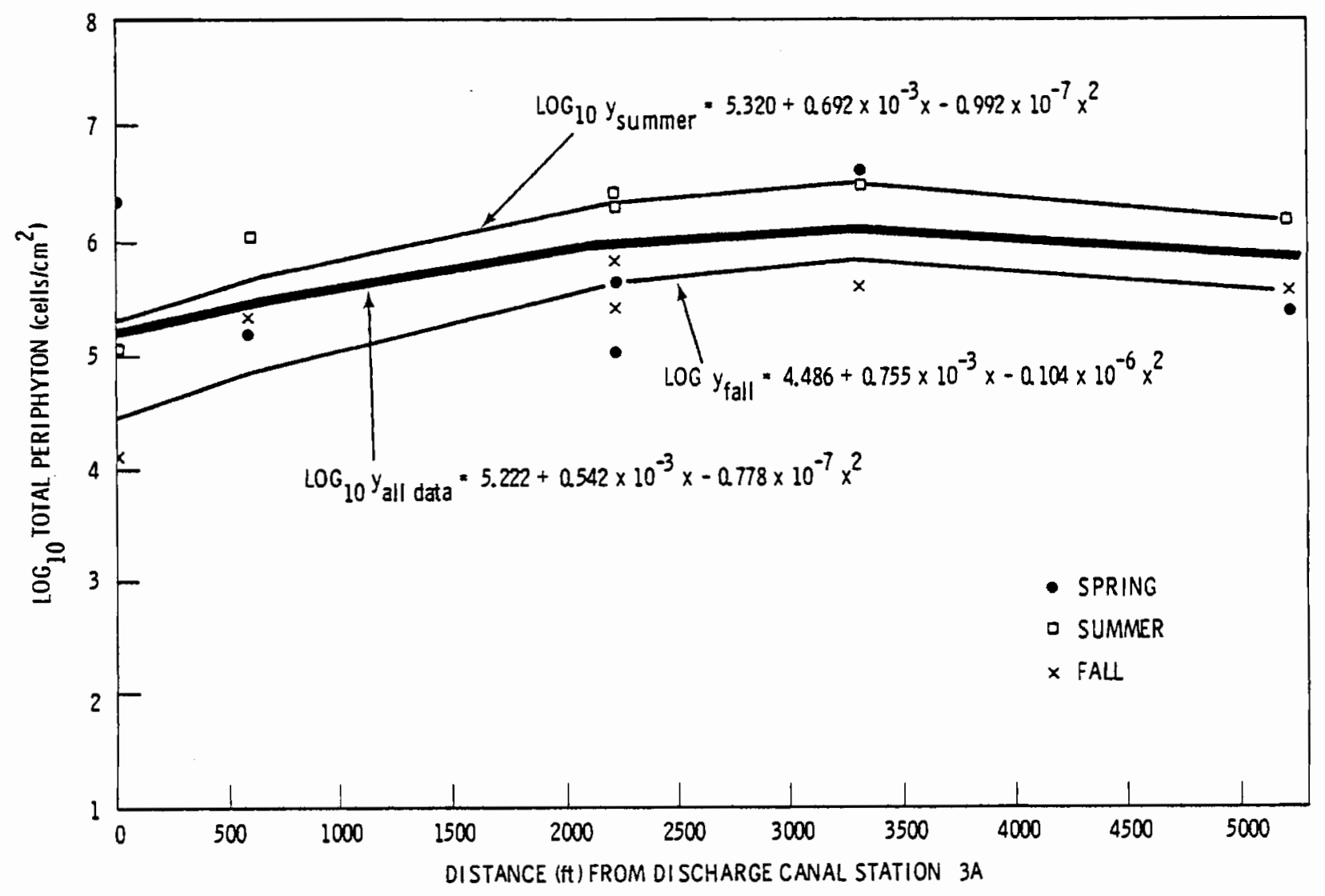

FIGURE 34. Total Periphyton (Log10) with Distance from Canal Station $3 A$ for $1974\left(\mathrm{ce} 11 \mathrm{~s} / \mathrm{cm}^{2}\right)$ 
In order to statistically evaluate some of the effects of Station $3 \mathrm{~A}$ counts on the regression models above, a one-way analysis of variance on each seasonal data set within years was performed (i.e., stations were considered treatments). The analysis was conducted on logarithmically transformed values and Duncan's Multiple Range Test was used to test for significant station differences for each season within years. The results in Table 29 show that total periphyton counts for Station $3 A$ were significantly lower $(P<0.05)$ than counts for all other stations in three of the four cases where seasonal regressions were significant (Figures 31-33). Moreover, the significant regression calculated for the summer of 1973, when Station $3 A$ was excluded, was partially due to low counts at Station 3 the next "downriver" station). Station 3 counts were also significantly $(P<0.05)$ lower than found for a 11 other downriver stations. Thus, it appears that a large portion of the relationship between distance (stressor) and total periphyton was associated with the area near the discharge canal.

TABLE 29. Results from One-Way Analyses of Variance of Log-Transformed (base 10) Total Periphyton $\left(\mathrm{ce} 11 \mathrm{~s} / \mathrm{cm}^{2}\right)$

\begin{tabular}{|c|c|c|c|c|c|}
\hline Year & Season & $\frac{\text { Calculated }}{F}$ & Probability & $\begin{array}{l}\text { Stations } \\
\text { Significantiy } \\
\text { Different } \\
\end{array}$ & Comments \\
\hline \multirow[t]{3}{*}{1972} & Spring & 0.16 & 0.97 & none & \multirow[t]{3}{*}{ Limited numbers of observations, Station $3 \mathrm{~A}$} \\
\hline & Summer & 1.16 & 0.36 & none & \\
\hline & Fall & 0.74 & 0.61 & none & \\
\hline \multirow[t]{3}{*}{1973} & Spring & 1.96 & 0.13 & none & \multirow{3}{*}{$s^{2}$ for Stations $3 A$ and 3 are significantly larger } \\
\hline & Surmer & 6.59 & 0.001 & $3 A<3<$ Rest & \\
\hline & Fall & (1) & (1) & (1) & \\
\hline \multirow[t]{3}{*}{1974} & Spring & 0.64 & 0.67 & none & \multirow{3}{*}{$\begin{array}{l}\text { Only } 1 \text { observation, Station } 7 \\
s^{2} \text { for Station } 3 A \text { is significantly larger }(P<.05)\end{array}$} \\
\hline & Surmer & 3.56 & 0.01 & $3 A<$ Rest & \\
\hline & Fall & 12.37 & 0.001 & $3 A<$ Rest & \\
\hline
\end{tabular}

(1) Limited number of obseryations. 
Summary

Analysis of periphyton data by species where comparisons of heated and control stations using Wilcoxon's Signed-Ranks test were made, provided little evidence of changes due to operation of Monticello Power Plant. However, because preoperational data were not available this observation is tentative and should be considered qualitative. Regression analysis indicated significantly lower total periphyton in the area near the discharge canal in some seasons. In addition, a one-way analysis of variance indicated that counts taken in the summer of $1973,550 \mathrm{ft}$ from the canal, were significantly lower than other downriver stations. Linear and quadratic regressions were usually not statistically significant if the data from Station $3 A$ (in the discharge canal) were excluded. 


\section{PERIPHYTON PRODUCTIVITY (CHLOROPHYLL-a)}

\section{Introduction}

In contrast to the periphyton abundance data where little preoperational data was taken, a complete year of preoperational (1970) chlorophyll-a (productivity) measurements were obtained. Thus, we utilized the ratio procedure (pseudodesign), explained in the section on benthos analysis for our statistical evaluation. In addition, sample replicates obtained in 1972 and 1973 enabled us to check the distributional assumptions for our statistical analysis of chlorophyll-a data measurements. Station locations, rationale for selection of those to be used in the statistical analysis of station ratios, and appropriate references are on page 87 . The complete individual sample data set and the calculated statistics for replicate measurements are in Appendix $G$. Concurrent data on temperature and current velocity data were obtained on each periphyton sampling date. These data sets were used in an attempt to construct a multiple regression model with productivity as the dependent variable.

Overview of the Data Set

Mean and standard deviations calculated for the three heated (Stations 3, 6, and 11) and three-control stations (Stations 2, 7, and 9) are presented in Table 30 , as well as the single determination for the discharge canal station ( $3 A)$. These data are also illustrated in Figure 35 . No differences attributable to reactor operations are readily apparent unless the few values in May, where means from heated stations appear to be consistently lower than those of control stations, were substantiated by additional observations. It appears that mean chlorophyll-a values are generally lower in spring but rise to a level in late June which is maintained until october (an expected finding). There is some visual evidence that mean values become more erratic in late September and October, perhaps reflecting the appearance or disappearance of seasonal species (see preceeding section on periphyton abundance). The mean and standard deviations calculated for three replicate chlorophyll-a measurements (through slides at the same station) taken during 1972 and 1973 (Appendix G) are plotted in 
Figure 36 in conjunction with a linear regression model fit to the observed data. The model suggests a constant coefficient or variation, in the range of $50 \%$ (with many deviations), which implies that the chlorophyll-a data are compatible with log-normal distribution.

\section{TABLE 30. Average Chlorophyll-a $\left(\mu \mathrm{g} / \mathrm{cm}^{2}\right)$ for Heated and Unheated Stations with Time}

\begin{tabular}{|c|c|c|c|c|c|c|c|c|c|c|c|}
\hline \multicolumn{3}{|c|}{ Unhea ted (Sta. $2,7,9)$} & \multicolumn{2}{|c|}{ Heated (Sta, 3,6,11) } & \multirow{2}{*}{$\begin{array}{l}\text { Discharge } \\
\text { Canal (3A) }\end{array}$} & \multirow{3}{*}{$\begin{array}{c}\begin{array}{c}\text { Date } \\
\text { Sampled }\end{array} \\
\underline{1973}\end{array}$} & \multicolumn{2}{|c|}{ Jnhes ted (Sta. $2,7,9)$} & \multicolumn{2}{|c|}{$\frac{\text { Heated (Sta. 3,6,11 }}{\text { Standard }}$} & \multirow{2}{*}{$\begin{array}{l}\text { Discharge } \\
\text { Canal (3A) }\end{array}$} \\
\hline $\begin{array}{c}\text { Date } \\
\text { Sampled } \\
\end{array}$ & Mean & $\begin{array}{c}\text { Standard } \\
\text { Deviation (1) }\end{array}$ & Mean & $\begin{array}{c}\text { Standard } \\
\text { Deviation (1) } \\
\end{array}$ & & & Mean & $\begin{array}{l}\text { Standar } \\
\text { Deviation }(1) \\
\end{array}$ & Mean & $\begin{array}{c}\text { Standard } \\
\text { Deviation(1) }\end{array}$ & \\
\hline 1970 & & & & & & & & & & & \\
\hline $5 / 19$ & 1.07 & 1.04 & 0.35 & & & $2 / 16$ & & & & & 0.80 \\
\hline $5 / 29$ & 0.91 & & 0.23 & 0.11 & & $3 / 5$ & & & & & 0.83 \\
\hline $6 / 12$ & 1.45 & 0.98 & 0.54 & 0.30 & & $4 / 24$ & 3.81 & 2.97 & 3.00 & 0.90 & 3.30 \\
\hline $6 / 26$ & 3.26 & & 1.36 & 1.17 & & $5 / 9$ & 2.42 & 0.95 & 3.90 & 1.61 & 1.44 \\
\hline $7 / 11$ & 1.18 & & 1.33 & 0.61 & & $5 / 22$ & 0.97 & 0.73 & 0.86 & 0.10 & 1.94 \\
\hline $7 / 28$ & 1.19 & & 1.39 & 0.12 & & $6 / 5$ & 1.37 & 1.46 & 1.18 & 0.74 & 0.08 \\
\hline $8 / 11$ & 1.41 & & 1.26 & & & $6 / 20$ & 2.58 & 0.45 & 2.91 & 0.62 & 1.33 \\
\hline $8 / 26$ & 2.14 & & 2.07 & & & $7 / 2$ & 2.84 & 0.33 & 2.48 & 0.22 & 0.48 \\
\hline $9 / 8$ & 2.18 & 0.38 & 2.00 & 0.24 & & $7 / 17$ & 2.90 & 0.54 & 2.37 & 0.10 & 0.16 \\
\hline $9 / 24$ & 3.24 & 1.60 & 2.17 & 0.75 & & $7 / 31$ & 1.89 & 0.42 & 1.92 & 0.22 & 0.42 \\
\hline $10 / 6$ & 1.57 & 1.21 & 1.53 & 0.71 & & $8 / 14$ & 2.23 & 0.17 & 2.16 & 0.17 & 0.68 \\
\hline $10 / 20$ & 6.89 & 6.15 & 6.71 & 3.96 & & $8 / 28$ & 1.61 & 0.67 & 1.86 & 0.80 & 0.07 \\
\hline $11 / 7$ & 8.69 & 4.86 & 8.35 & 5.77 & & $9 / 11$ & 2.10 & 0.14 & 2.37 & 0.20 & 0.18 \\
\hline 1971 & & & & & & $9 / 24$ & 1.85 & 1.19 & 2.56 & 0.77 & 0.27 \\
\hline $2 / 16$ & 0.02 & & 0.01 & & & $10 / 9$ & 1.30 & 1.46 & 0.88 & 0.17 & 1.00 \\
\hline $3 / 4$ & 0.00 & & 0.00 & & & $10 / 26$ & & & & & 0.51 \\
\hline $5 / 13$ & 1.27 & 1.07 & 0.46 & 0.28 & 0.87 & $11 / 9$ & 0.11 & 0.04 & 0.06 & 0.03 & 0.12 \\
\hline $5 / 27$ & 0.98 & 1.40 & 0.28 & 0.18 & 0.31 & $11 / 23$ & 0.04 & 0.03 & 0.02 & 0.03 & 0.06 \\
\hline $6 / 10$ & 0.90 & 0.65 & 0.44 & & 1.68 & $\underline{1974}$ & & & & & \\
\hline $6 / 24$ & 2.91 & 1.11 & 2.77 & 2.11 & 3.65 & $5 / 23$ & 1.40 & & 0.07 & 0.06 & 1.43 \\
\hline $7 / 9$ & 2.55 & & 1.38 & 0.90 & 0.26 & $6 / 10$ & 2.35 & • & 1.59 & 0.71 & 0.45 \\
\hline $7 / 22$ & 2.84 & & 1.83 & 1.13 & 1.16 & $6 / 25$ & 1.59 & 1.06 & 1.58 & 0.34 & 0.39 \\
\hline $8 / 5$ & 2.32 & 0.82 & 2.26 & 0.72 & 3.02 & $7 / 9$ & 2.09 & 1.04 & 1.85 & 0.38 & 4.61 \\
\hline $8 / 19$ & 2.07 & 0.65 & 2.42 & 0.21 & 0.37 & $7 / 23$ & 1.63 & 0.65 & 1.40 & 0.81 & 0.92 \\
\hline $9 / 2$ & 1.69 & 0.58 & 1.53 & 0.36 & 0.17 & $8 / 5$ & 2.28 & 0.46 & 2.13 & 0.07 & 0.67 \\
\hline $9 / 15$ & 1.75 & 0.99 & 1.64 & 0.51 & 0.13 & $8 / 20$ & 2.50 & 0.50 & 2.60 & 0.72 & 1.80 \\
\hline $9 / 30$ & 1.68 & 1.47 & 0.96 & 0.43 & 0.73 & $9 / 4$ & 3.76 & 1.35 & 2.95 & 1.24 & 0.56 \\
\hline $10 / 14$ & 2.50 & 0.65 & 0.91 & 1.08 & 0.65 & $9 / 19$ & 3.08 & 0.91 & 4.32 & 1.16 & 0.00 \\
\hline $10 / 28$ & 2.64 & & 1.02 & & 0.45 & $10 / 2$ & 2.53 & 0.71 & 1.70 & $0.5]$ & 0.22 \\
\hline 1972 & & & & & & $10 / 16$ & 3.79 & 1.63 & 4.31 & 0.94 & 0.00 \\
\hline $5 / 22$ & 0.44 & 0.34 & 0.12 & 0.10 & 0.36 & $10 / 31$ & 4.36 & 1.43 & 3.09 & 0.89 & 0.89 \\
\hline $6 / 5$ & 0.44 & 0.28 & 0.36 & 0.10 & 0.21 & & & & & & \\
\hline $6 / 19$ & 1.28 & 1.06 & 1.39 & 0.63 & 1.68 & & & & & & \\
\hline $7 / 4$ & 1.95 & 0.51 & 1.83 & 0.48 & 0.21 & & & & & & \\
\hline $7 / 17$ & 2.78 & 0.60 & 2.27 & 0.46 & 0.96 & & & & & & \\
\hline $7 / 31$ & 2.81 & & & & 3.35 & & & & & & \\
\hline $8 / 15$ & 2.05 & & & & 0.35 & & & & & & \\
\hline $9 / 1$ & 2.96 & 2.64 & 0.95 & 0.17 & 0.81 & & & & & & \\
\hline $9 / 18$ & 1.07 & 0.57 & 1.31 & 0.68 & 0.15 & & & & & & \\
\hline $10 / 3$ & 2.16 & 0.93 & 2.77 & 1.58 & 0.04 & & & & & & \\
\hline $10 / 16$ & 1.61 & 0.90 & 2.03 & 1.14 & 0.13 & & & & & & \\
\hline $11 / 1$ & 1.31 & 0.51 & 6.54 & 2.09 & 0.03 & & & & & & \\
\hline $11 / 28$ & 0.16 & & & & 0.06 & & & & & & \\
\hline
\end{tabular}

(1) ATl three stations are reported when a standard deviation is recorded. 


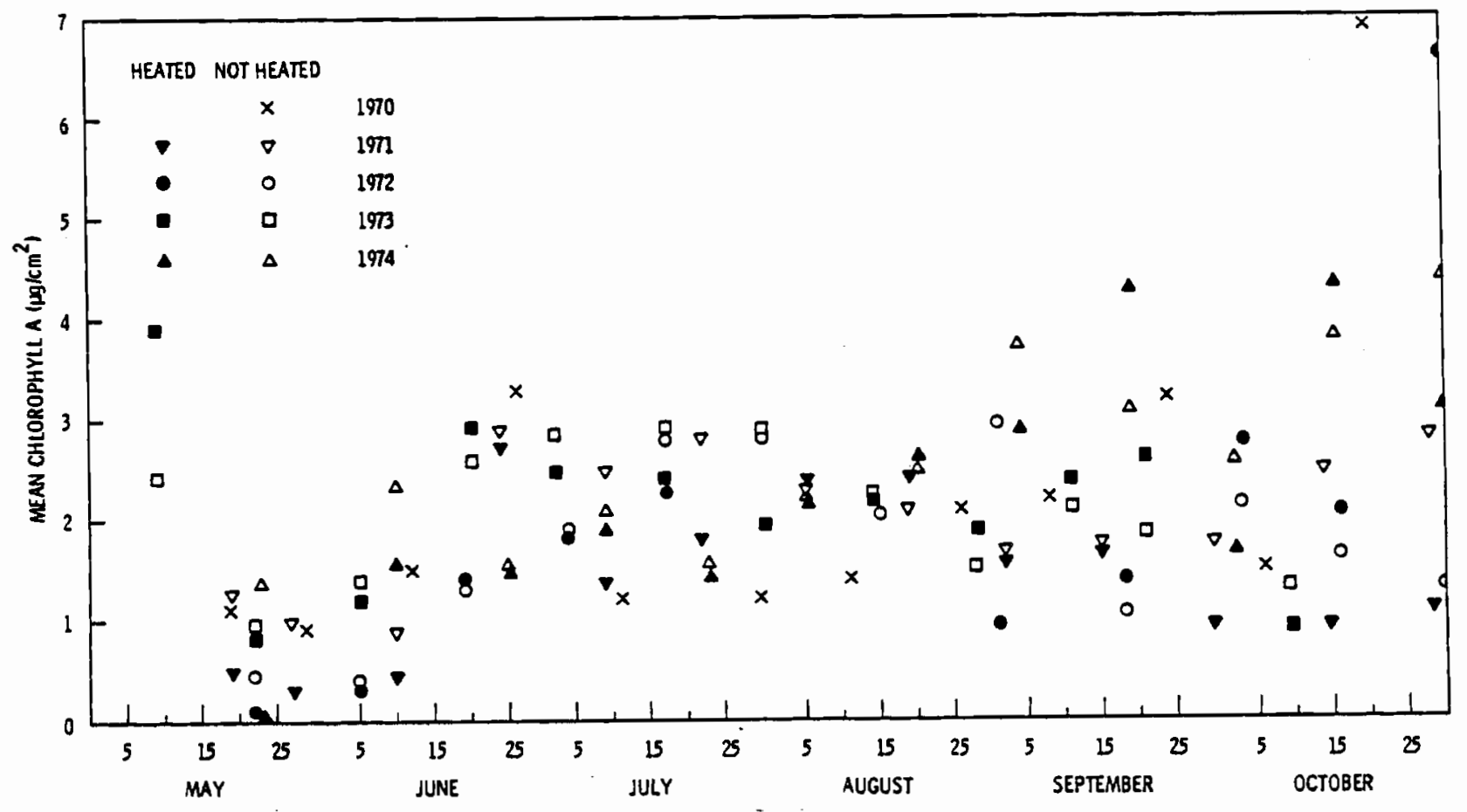

FIGURE 35. Comparison of Seasonal Relationship Between Mean Chlorophy 11 -a for Heated Stations (3, 6, 11) and Unheated Stations $(2,7,9)$

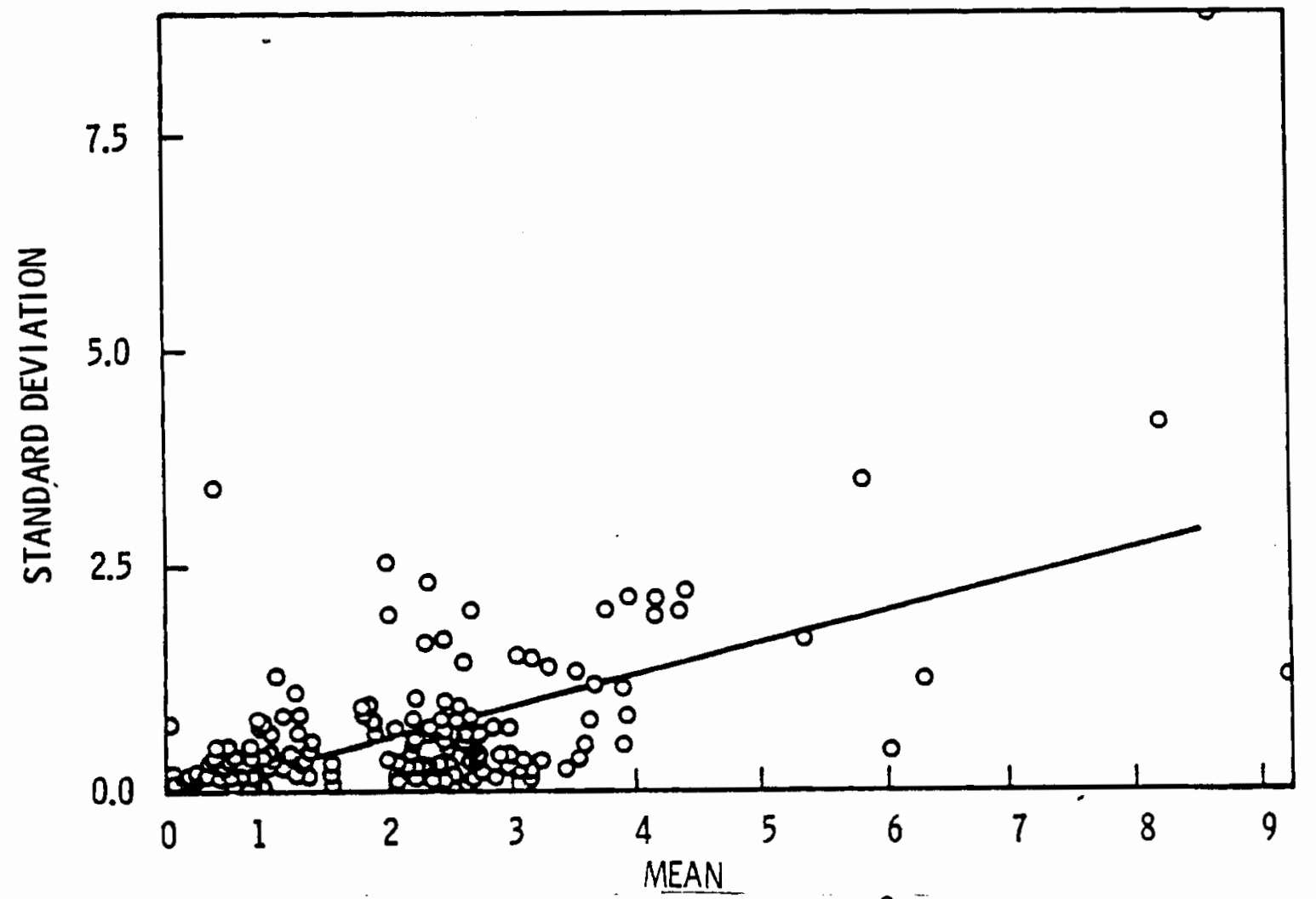

FIGURE 36. Mean Chlorophyll-a $\left(\mu \mathrm{g} / \mathrm{cm}^{2}\right)$ for Three Replicate Slides Versus The Respective Standard Deviation 


\section{Ratio Tests}

Both arithmetic and logarithmic ratios calculated for individual heated/control pairs as well as selected stem and leaf displays are in Appendix $G$. As found in the benthos analysis, the displays support the log transformation of ratios. Arithmetic and logarithmic means and other statistics are presented by year in Table 31. Even though the station arithmetic ratios, $3 / 7$ and $11 / 2$, for operational years were numerically larger than the preoperational year (1970) ratios, the statistical variation was too great for differences to be significant. This is shown in Table 32 where the results of a one-way analysis of variance on $\log$ transformed ratios are presented. Each station ratio was analyzed separately and no significant differences were detected between preoperational and operational years. Moreover, examination of the arithmetic means for the $3 / 7$ station ratio (Table 31) indicates that only 1971 and 1973 exhibited ratios substantially higher than the 1970 values. Further examination of individual ratios (by date, Appendix G) for 1971 and 1973 shows several very large values which influenced mean values and caused the higher coefficients of variations shown in Table 31 (also examine individual values for the 11/2 ratio in 1973; Appendix $G$ ). The mean yearly values for the station ratio 6/9 (Table 31) generally declined compared to the 1970 mean. Thus, a definitive statement relating the operation of the Monticello Power Plant to periphyton productivity would have been impossible had the general, but not significant, trends discussed above been statistically validated, since changes relative to the preoperational year were inconsistent. Multiple Regression Model

The best result obtained using stepwise multiple regression to devise a model of periphyton productivity is in Table 33. The percentage of explained variation was $63 \%$, and occurred when a quadratic temperature term entered the equation. While this latter term appears to have no biological interpretation, the measured water temperature from one prior period could be explained. Apparently either more sophisticated models with additional variables, more precise data, or both will be needed to improve the model to a point where "projections" could be attempted to future years. 


\section{TABLE 31. Yearly Statistical Summary of Arithmetic and Logarithmic Ratios of Chlorophyll-a $\left(\mu \mathrm{g} / \mathrm{cm}^{2}\right)$ for Heated/Control Station Ratios}

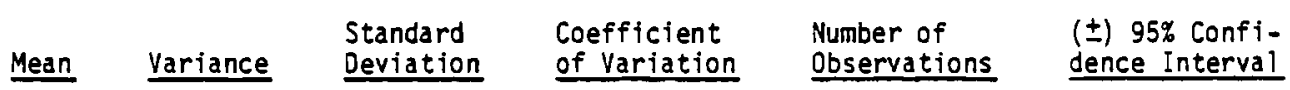

Arithmetic Ratios

$3 / 7$

$\begin{array}{rrrrrrr}70 & 1.32 & 0.53 & 0.73 & 55 & 8 & 0.16 \\ 71 & 2.56 & 15.44 & 3.93 & 154 & 10 & 2.81 \\ 72 & 1.82 & 2.31 & 1.52 & 84 & 10 & 1.09 \\ 73 & 2.01 & 4.12 & 2.03 & 101 & 15 & 1.12 \\ 74 & 1.49 & 1.69 & 1.30 & 87 & 10 & 0.93\end{array}$

$6 / 9$

$\begin{array}{rrrrrrr}70 & 1.15 & 0.89 & 0.94 & 82 & 11 & 0.63 \\ 71 & 0.65 & 0.14 & 0.38 & 58 & 12 & 0.25 \\ 72 & 1.44 & 3.69 & 1.92 & 133 & 11 & 1.29 \\ 73 & 0.84 & 0.10 & 0.31 & 37 & 15 & 0.17 \\ 74 & 0.83 & 0.16 & 0.39 & 47 & 12 & 0.25 \\ 2 & & & & & & \\ 70 & 0.63 & 0.13 & 0.36 & 57 & 12 & 0.23 \\ 71 & 1.09 & 2.13 & 1.46 & 134 & 12 & 0.93 \\ 72 & 1.23 & 1.01 & 1.01 & 82 & 10 & -72 \\ 73 & 2.51 & 20.84 & 4.57 & 182 & 15 & 2.53 \\ 74 & 1.09 & 1.39 & 1.18 & 108 & 12 & 0.75\end{array}$

Logarithmic Ratios

$3 / 7$

$+0.057$

$+0.131$

$+0.141$

$+0.171$

0.068

0.235

0.110

0.096

0.261

0.485

0.332

0.311

0.248

0.16

1.09

.12

$6 / 9$

$-0.082$

$-0.277$

$-0.022$

$-0.108$

0.061

0.386

0.153

0.658

0.317

0.187

0.316

0.212

0.359

0.186

0.63

1.29

0.17

0.23

0.72

0.75

$11 / 2$

$\begin{array}{lll}-0.310 & 0.154 & 0.392 \\ -0.453 & 0.658 & 0.811 \\ -0.066 & 0.187 & 0.433 \\ +0.090 & 0.217 & 0.461 \\ -0.161 & 0.263 & 0.531\end{array}$

8
10
10
15
10

11
12
11
15
12

70
71
72
73
74

12
12
10
15
12 
TABLE 32. Results from One-Way Analyses of Variance of Log Transformed (Base 10) Chlorophyll-a $\left(\mu \mathrm{g} / \mathrm{cm}^{2}\right)$ for Heated/Control Station Ratios

\begin{tabular}{|c|c|c|c|c|}
\hline \multirow{2}{*}{$\begin{array}{c}\text { Station } \\
\text { Ratio } \\
\end{array}$} & \multicolumn{2}{|c|}{ F-Test } & \multirow[t]{2}{*}{$\begin{array}{c}\text { Stations } \\
\text { Significantly } \\
\text { Different } \\
(P<0.05) \\
\end{array}$} & \multirow{2}{*}{ Comments } \\
\hline & & & & \\
\hline $6 / 9$ & 1.08 & 0.38 & none & Variances homogeneous \\
\hline $11 / 2$ & 1.97 & 0.11 & none & Variances homogeneous \\
\hline $3 / 7$ & 0.18 & 0.95 & none & Variances homogeneous \\
\hline
\end{tabular}

TABLE 33. Results from Fitting a Stepwise Multiple Regression Model to Periphyton Productivity Data

Chlorophyll-a Multiple Regression Model

Variables Used

Biomass $=$ Chlorophyll-a

Current speed ( $\mathrm{ft} / \mathrm{sec})$

River temperature $\left({ }^{\circ} \mathrm{C}\right)$

Dummy variable for month

Time (day of year) Best Results Were $R^{2}=.63$

Temperature was lagged one sampling period The square of temperature was used in the model

Summary

No statistically significant differences in periphyton productivity were attributed to the operation of the Monticello Power Plant. Qualitative examination of the data suggested some possible effects but these were rejected on the basis of inconsistencies in the data. Our efforts to devise a multiple regression model to explain the productivity data were not successful enough to attempt extrapolations to future years. 


\section{FISH STUDIES}

Introduction

Fish studies utilized electrofishing, seining and creel census procedures to assess species composition and/or population densities. Special studies of impingement, entrainment and cold shock were also initiated. A portion of the 1968-1969 electrofishing study was devoted to a tag-recapture assessment to obtain population estimates for several species. These estimates were also used as an aid in interpretation of a later cold-shock study conducted in 1974. We were unable to statistically evaluate most of the data from these studies for various reasons including lack of catch effort data in the preoperational electrofishing study and incomplete and biased monitoring for impingement and entrainment experiments. Additional specific problems are addressed for each study below, and some qualitative interpretations are offered where appropriate.

Electrofishing

The complete data set for 1973 and 1974 is listed in Appendix H. Explanation of the categories rough and game fish and some further detail are in Tables 34-37 where the data are presented in a different format and additional results for a few specific species are presented. Discharge areas used as headings are those defined by the State of Minnesota (see footnote Table 13). In addition, the available preoperational 1968 data are shown in Table 38. We were unable to assess these data because, a) no shocking times were given so no catch/effort calculations were possible, b) different sectors were shocked far apart in time, see the top of Table 38, and c) there was inconsistent fishing pressure in each sector, third title line of the same table. Electroshocking data for 1969 were reported as totals with no sector differentiation, so the second preoperational year of data was unusable for analysis. The rough fish catch/effort data for 1973 and 1974 are plotted in Figures 37 and 38 because we hoped to find a visually apparent relationship. While no consistent gradation in decreasing catch/ effort of the control, outer, intermediate and immediate discharge areas was found, both yearly data sets indicate diminished rough fish catches in the 
immediate area when compared to other areas. This result may be a consequence of the larger number of samples (Appendix $\mathrm{H}$ ) obtained for these areas. Preoperational data might have clarified this point. Too few measurements (i.e., no catch or small catch/effort values) were available for game fish to allow a similar qualitative visual appraisal. A portion of the tagrecapture data for smallmouth bass obtained during 1968-1969 and used to assess population size is presented in Table 39. Estimates for other species, usually based on a few more recaptures, are found in Hopwood (1970). The size estimates presented there and the final value (609) in Table 39 are of questionable reliability because the Schnabel method, applied by the consultant, assumes a constant population with no recruitment or mortality; hardly the situation in a usually fast-flowing river. The failure to correct for this assumption in a two-year study seems serious. Further, statistical bias (see Ricker, 1975, p. 79) results when either the number of fish marked and examined or the number of recaptures is low (less than 4 is suggested as low by Ricker (1975)). Finally even though the above limitations are ignored, no assessment of variability is presented for any of the population estimates. The intervals are quite large, for example, for smallmouth bass we have estimated the $95 \%$ confidence interval (using a Poisson approximation) as 238 to 2432 for the population value (609) given in Table 39. This latter result suggests that many more smallmouth bass should be marked and recaptured so a more reliable population estimate can be obtained; providing that the assumption that smallmouth bass neither emigrate, immigrate, die, or new fish are recruited over two years is even reasonably valid. Ricker (1975, p. 91) suggests the problem is tractable for some species of riverine fish but presumably over shorter time intervals. 


\section{TABLE 34. Electrofishing Catch Per Unit Effort}

(fish/hr) in the Sector "A" (Control)

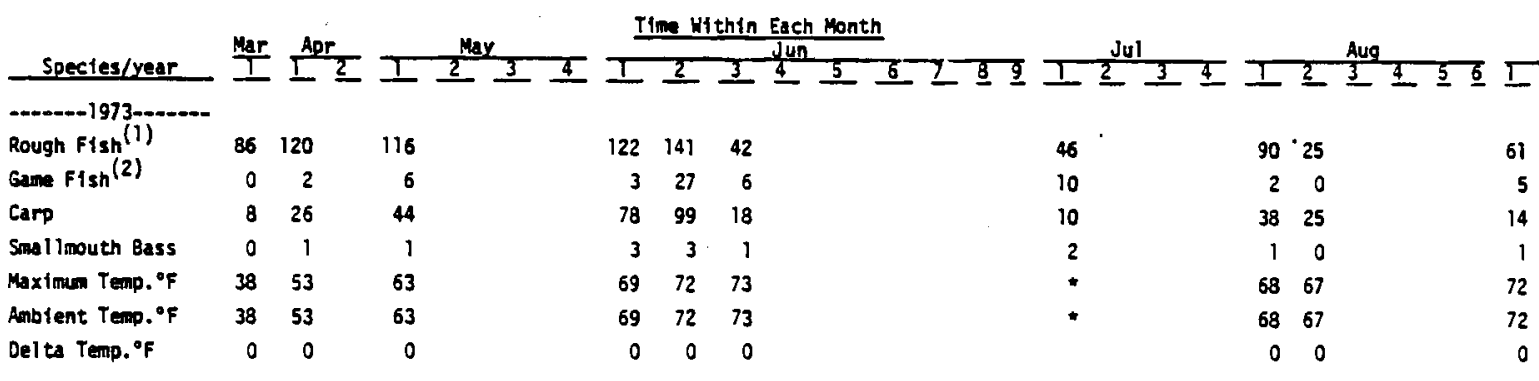

$\begin{array}{lrrrrrrrrr}\text { Rough Fish } & * & 54 & 129 & 106 & 233 & 130 & 133 & 162 & 189 \\ \text { Game Fish } & * & 0 & 1 & 1 & 7 & 2 & 49 & 36 & 12 \\ \text { Carp } & * & 11 & 66 & 48 & 8 & 36 & 58 & 81 & 113 \\ \text { Shorthead Redhorse } & * & - & - & - & - & - & - & - & - \\ \text { Smallmouth Bass } & * & 0 & 1 & 0 & 7 & 2 & 6 & 1 & 1 \\ \text { Maximun Temp. }{ }^{\circ} \mathrm{F} & * & 40 & 49 & 54 & 50 & 50 & 65 & 68 & 65 \\ \text { Ambient Temp. }{ }^{\circ} \mathrm{F} & * & 40 & 49 & 54 & 50 & 50 & 65 & 68 & 65 \\ \text { Delta Temp. }{ }^{\circ} \mathrm{F} & * & 0 & 0 & 0 & 0 & 0 & 0 & 0 & 0\end{array}$

No Sample

(1) Rough fish spectes included: shorthead redhorse, carp, stlver redhorse, black bullhead, barbot, brown bullhead and white sucker

(2) Game fish species included: rock bass, black crapple, walleye, northern plke, pumpkinseed, smail lmouth bass and bluegill.

TABLE 35. Electrofishing Catch Per Unit Effort (fish/hr) in the Outer Discharge Area (Along Shore Opposite Discharge Canal)

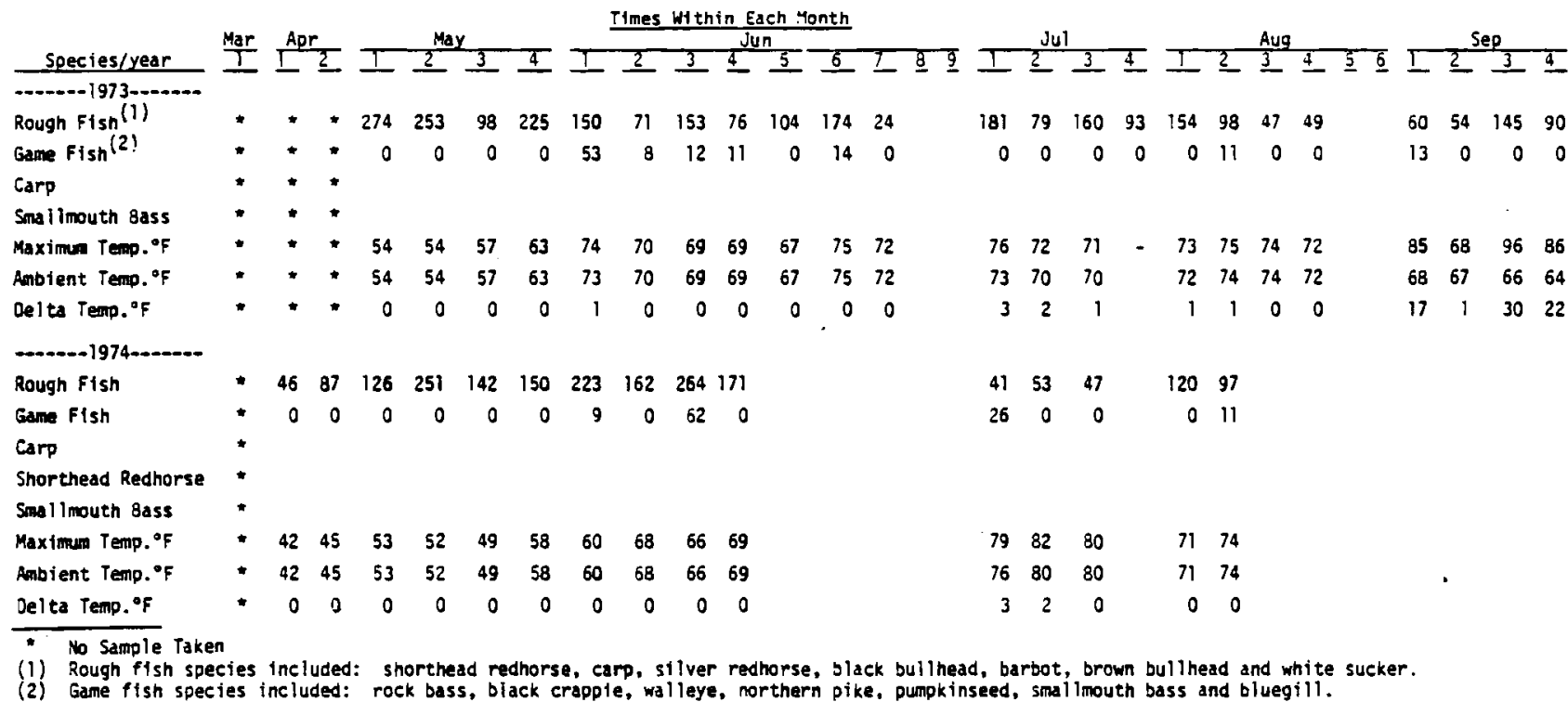




\section{TABLE 36. Electrofishing Catch Per Unit (fish/hr) Effort in the Intermediate Discharge Zone (Within $3^{\circ} \mathrm{F}$ Isotherm)}

\begin{tabular}{|c|c|c|c|c|c|c|c|c|c|c|c|c|c|c|c|c|c|c|c|c|c|c|c|c|c|c|c|c|}
\hline \multirow{2}{*}{ Species/year } & \multirow{2}{*}{$\frac{\text { Mar }}{1}$} & \multicolumn{2}{|c|}{ Apr } & \multicolumn{4}{|c|}{ May } & \multicolumn{9}{|c|}{$\begin{array}{l}\text { Times Within Each Month } \\
\text { Jun }\end{array}$} & \multicolumn{3}{|c|}{ jul } & \multicolumn{6}{|c|}{ Aug } & \multicolumn{3}{|c|}{ Sep } \\
\hline & & & ? & 1 & $\underline{?}$ & 3 & 4 & 1 & $\underline{2}$ & 3 & 4 & 5 & 6 & 7 & 8 & 9 & 1 & 2 & & 1 & 2 & 3 & 4 & $\underline{5}$ & $\underline{6}$ & $I$ & 2 & 34 \\
\hline - & & & & & & & & & & & & & & & & & & & & & & & & & & & & \\
\hline Rough Fish $(1)$ & 0 & - & 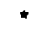 & 48 & 24 & 22 & 150 & 30 & 38 & 70 & 38 & 10 & 6 & 33 & 5 & 8 & 55 & - & 76 & 14 & 4 & 5 & 16 & 4 & 19 & 10 & 13 & 24 \\
\hline Gane Fish ${ }^{(2)}$ & 0 & $\bullet$ & - & 3 & 18 & 0 & 7 & 21 & 40 & 18 & 15 & 17 & 11 & 13 & 6 & 9 & 13 & 11 & 18 & 15 & 0 & 16 & 6 & 0 & 12 & 9 & 0 & 18 \\
\hline Carp & 0 & $\star$ & $\bullet$ & 24 & 8 & 5 & 140 & 27 & 35 & 52 & 27 & 8 & 4 & 16 & 3 & 0 & 15 & 0 & 65 & 13 & 3 & 4 & 13 & 4 & 15 & 7 & 5 & 19 \\
\hline Smallmouth Bass & 0 & * & - & 0 & 0 & 0 & 0 & 3 & 0 & 6 & 5 & 8 & 7 & 7 & 5 & 8 & 10 & 7 & 16 & 0 & 0 & 5 & 0 & 0 & 7 & 9 & 0 & 16 \\
\hline Maximum Tenp. ${ }^{\circ} \mathrm{F}$ & 40 & 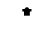 & $=$ & 56 & 56 & 88 & 95 & 86 & 89 & 91 & 93 & 76 & 72 & 84 & 104 & 104 & 85 & 86 & 70 & 77 & 79 & 91 & 88 & 86 & 94 & 98 & 98 & 88 \\
\hline Anbient Temp. ${ }^{\circ} F$ & 40 & 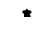 & - & 56 & 56 & 63 & 68 & 68 & 76 & 76 & 76 & 71 & 72 & 70 & 75 & 73 & 73 & 70 & 70 & 72 & 74 & 75 & 73 & 74 & 73 & 71 & 69 & 63 \\
\hline Oeita Temp. ${ }^{\circ} \mathrm{F}$ & 0 & $*$ & $\bullet$ & 0 & 56 & 15 & 27 & 18 & 13 & 15 & 17 & 5 & 0 & 14 & 29 & 31 & 12 & 16 & 0 & 5 & 5 & 16 & 15 & 12 & 21 & 27 & 29 & 25 \\
\hline 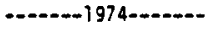 & & & & & & & & & & & & & & & & & & & & & & & & & & & & \\
\hline Rough Fish & $*$ & 68 & 47 & 66 & 51 & 264 & 147 & 58 & 16 & 45 & 52 & & & & & & 14 & 0 & & & & & & & & & & \\
\hline Game Fish & 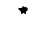 & 21 & 6 & 9 & 5 & 5 & 0 & 13 & 0 & 0 & 0 & & & & & & 10 & 0 & & & & & & & & & & \\
\hline Carp & $\bullet$ & 13 & 13 & 15 & 18 & 76 & 20 & 31 & 11 & 30 & 39 & & & & & & 8 & 0 & & & & & & & & & & \\
\hline Shorthead Redhorse & - & 28 & 17 & 19 & 14 & 48 & 63 & 12 & 4 & 0 & 0 & & & & & & 0 & 0 & & & & & & & & & & \\
\hline Ambient Tenp. ${ }^{\circ} \mathrm{F}$ & - & 44 & 42 & 55 & 52 & 62 & 62 & 68 & 72 & 70 & 77 & & & & & & 83 & 77 & & & & & & & & & & \\
\hline Deita Temp. ${ }^{\circ} \mathrm{F}$ & $\bullet$ & 0 & 0 & 0 & 0 & 12 & 21 & 24 & 19 & 24 & 13 & & & & & & 0 & 11 & & & & & & & & & & \\
\hline
\end{tabular}

No Sample

(1) Rough fish species included: shorthead redhorse, carp, silver redhorse, black bullhead, barbot, brown bullhead and white sucker

(2) Game fish species included: rock bass, black crappie, wolleye, northern pike, pumpkinseed, smil lmouth bass and bluegill.

\section{TABLE 37. Electrofishing Catch Per Unit (fish/hr) Effort in the Immediate Discharge Zone (Within Discharge Canal)}

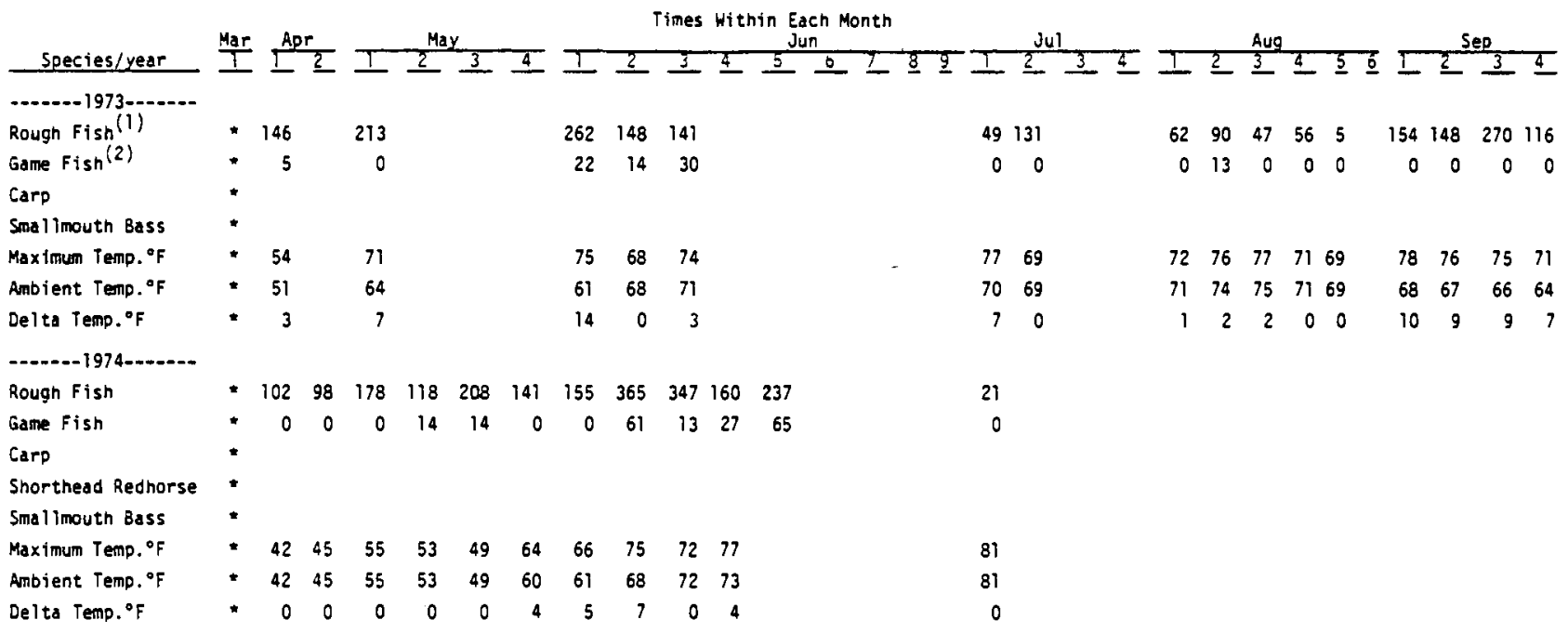

No Sample

(1) Rough fish species included: shorthead redhorse, carp, silver redhorse, black builhead, barbot, brown bullhead and whize sucker

(2) Game fish species included: rock bass, black crappie, walleye, northern pike, pumpkinseed, smallmouth bass and bluegill. 
TABLE 38. Number of Fish Caught Per Electrofishing Run for the Period September 9, 1968 and October 4, 1968

\begin{tabular}{|c|c|c|c|c|c|c|c|c|c|c|c|c|c|c|c|c|c|c|c|c|c|c|c|c|c|c|c|c|}
\hline Species & \multicolumn{10}{|c|}{ Sector " $A$ " (Runs) } & \multicolumn{7}{|c|}{ Sector "8" (Runs) } & \multicolumn{6}{|c|}{$\frac{\text { Sector "C" (Runs) }}{28 \operatorname{sen}^{680}}$} & \multicolumn{2}{|c|}{ 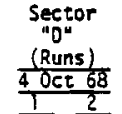 } & \multicolumn{2}{|c|}{$\begin{array}{l}\text { Sector } \\
\text { "E" } \\
\text { (Runs) }\end{array}$} & $\begin{array}{l}\text { Grand } \\
\text { Iotal }\end{array}$ \\
\hline Northern Redhorse & 6 & 5 & 17 & 5 & 4 & 8 & 7 & 15 & 11 & 13 & 16 & 18 & 14 & 13 & 32 & 25 & 28 & $28 \quad 24$ & , & 13 & 16 & 2 & 11 & 14 & 22 & 7 & 21 & 412 \\
\hline Carp & 10 & 30 & 9 & 17 & 10 & 18 & 7 & 9 & 11 & 13 & 5 & 2 & 5 & 13 & 2 & 3 & 10 & 63 & & 5 & 6 & 3 & 12 & 10 & 10 & & 9 & 245 \\
\hline Silver Redhorse & 1 & & & 2 & 3 & 3 & 3 & 3 & 2 & & 1 & 1 & & 1 & & & 1 & 1 & & & 2 & 1 & 2 & & & & 1 & 29 \\
\hline Walleye & & 2 & & 1 & 1 & 3 & & 1 & & 2 & & & & & & & & 4 & & & & 2 & & & & 2 & & 18 \\
\hline Rock Bass & & 1 & & & & & & & & & & & & & & & & & 13 & & & & 2 & 1 & & & & 17 \\
\hline Smallimouth Bass & & 3 & & & 1 & & 2 & & $\mathbf{1}$ & & & & & 1 & & & & & & 1 & & & & $\mathbf{1}$ & & 2 & & 12 \\
\hline Black Crapple & & 1 & & & & & & & & 2 & & & & & & & & & 5 & & & & & & & 2 & & 10 \\
\hline Northern Pike & & & & & & & & & & 2 & & & & & & & & & & & & & & & & & & 2 \\
\hline Yellow Perch & & & & & & & & & & & & & & & & & & & & & & & & 1 & & & & 1 \\
\hline TOTAL & & & & & & & & & & & & & & & & & & & & & & & & & & & & 746 \\
\hline
\end{tabular}

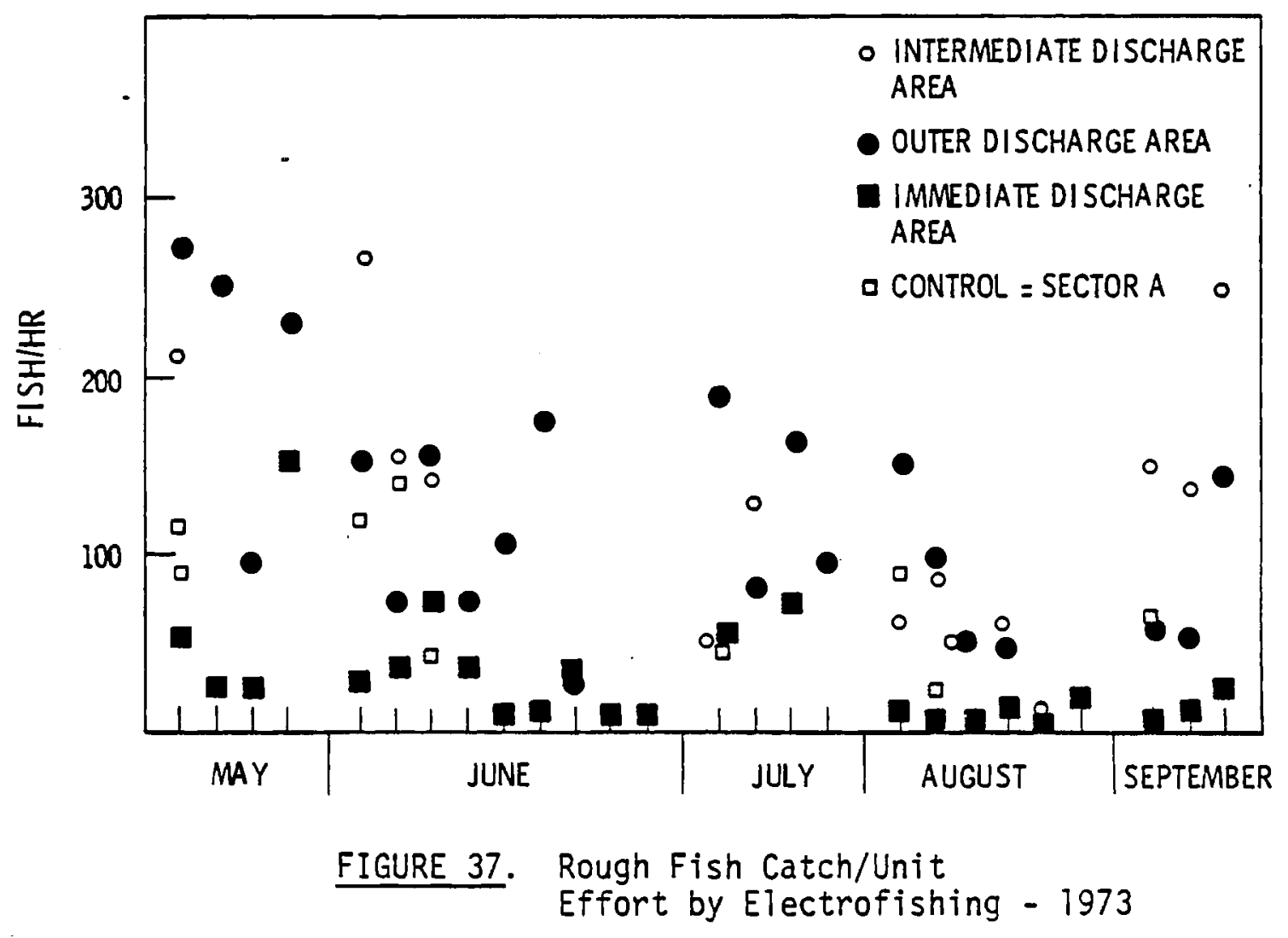


TABLE 39. Population Estimates of Smallmouth Bass, Schnabel Method

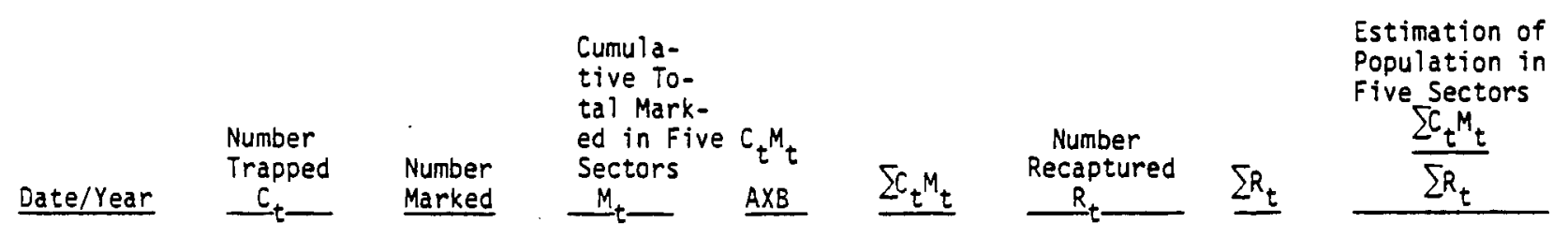

$8 / 17$

$8 / 20$

$8 / 26$

$9 / 4$

$9 / 5\}$

$9 / 6)$

$9 / 9$

$9 / 10$

$9 / 21$

$10 / 4$

$10 / 24$

$10 / 25$

--1969---

$6 / 16$

$7 / 7$

$7 / 16$

$7 / 21$

$7 / 23$

$7 / 28$

$7 / 30$

$7 / 31$

$8 / 5$

$8 / 7$

$8 / 16$

$8 / 18$

$9 / 16$

$9 / 20$

$9 / 23$

Marked

M

Recaptured
176

239

263

313

340

367

421

450

510

574

642

894

1002

1041

1201

622

426

333

454

564

609 


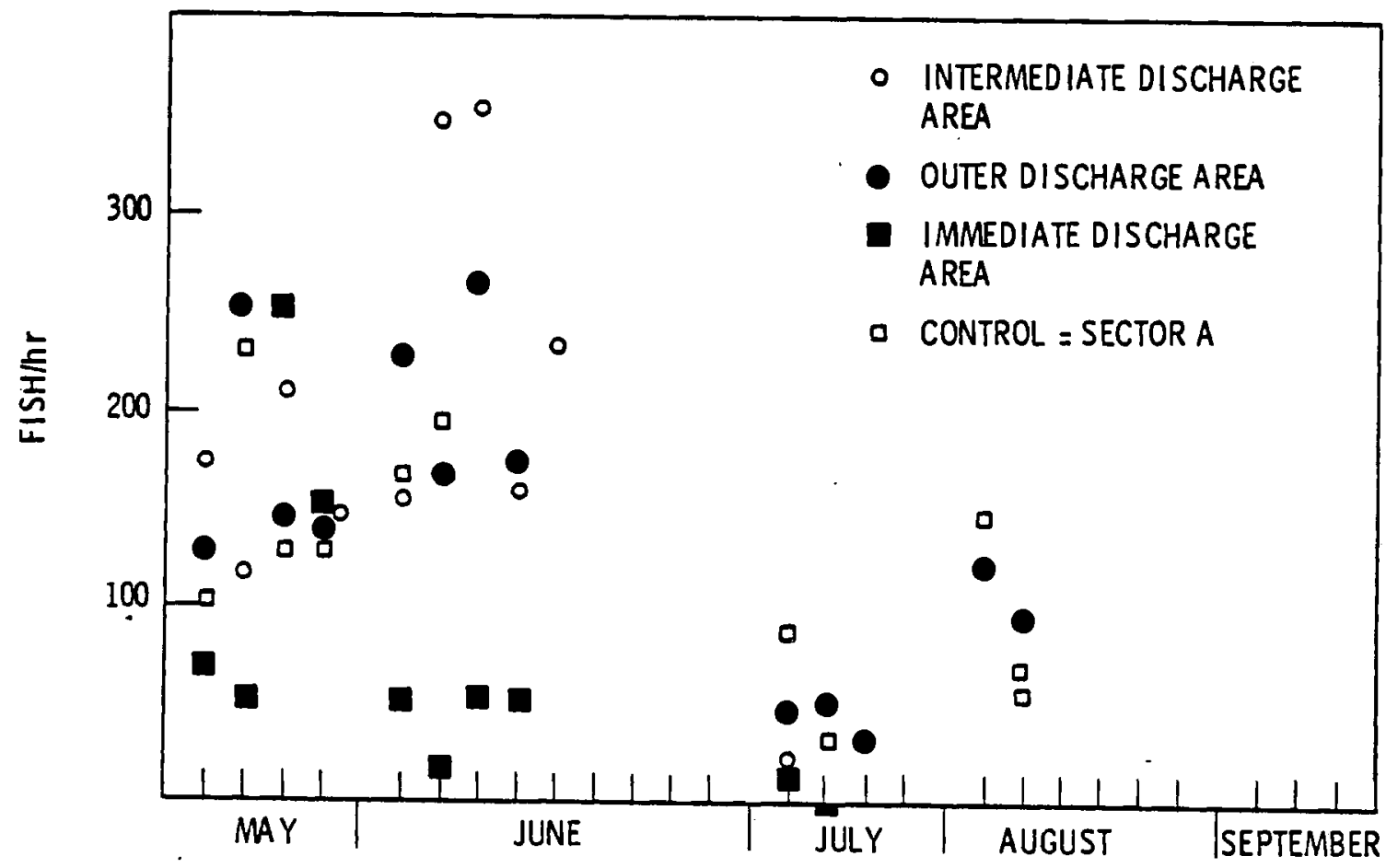

FIGURE 38. Rough Fish Catch/Unit Effort by Electrofishing - 1974

Seining

The available data where the same river areas were fished both preoperationally and operationally are given in Table 40. Total catch was reported without any effort data nor an indication of sampiing frequency or dates. Hopwood (1974b), indicates that since the percentage distribution for fish totaled over the stations shown in Table 40 did not change during the operational and preoperational periods that the heated water had no effect on the fishing (using rank correlation analysis of operational and preoperational percentage species distribution data). In the absence of effort data or an indication of the dates actualiy fished, this may be a premature conclusion because it is based on a statistical procedure which ignores the numerical magnitude of species changes. 
TABLE 40. Numbers of Fish Collected by Seining for Stations* Fished in 1970 and 1972-1973

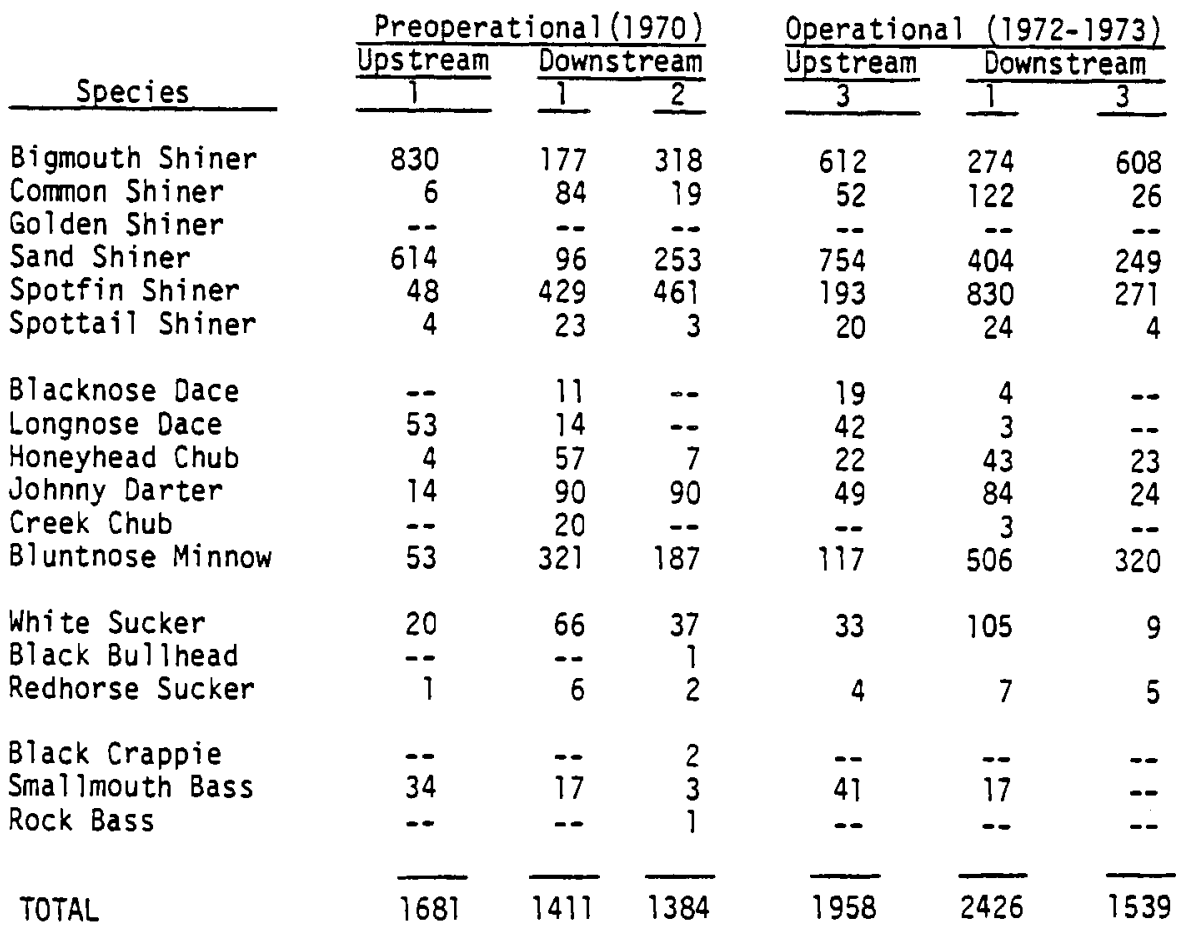

*Preoperational upstream 1 same as station operational upstream 3 and preoperational dowostream 2 same station as operational downstream 3; where upstream are --

It seems incongruous that some differences in species proportions at the same sampling station were not detected after 2 to 3 years. Therefore, we calculated a chi-square (independence) for numbers observed at Station 1 downstream for the operational and preoperational periods which we found to be highly significant $(P<0.01)$. Perusal of Table 40 for disproportionate changes indicates the species which are the large contributors to chi-square (e.g., sand shiners for large numbers observed and creek chubs for small numbers observed). Of course there is no way to distinguish which factor(s) may be the cause of this high chi-square. Some possible compounding factors in addition to operational and preoperational status include differences in 
years, months, temperature, river level and combinations of these factors. Because of these changes at the same stations we calculated the percentage of fish seined during preoperational and operational times at upstream and downstream stations (Table 41) to assess possible changes due to operation of the plant. In addition we calculated an analysis of variance for the percentage data (Table 41). Apparently most of the percentage changes are associated with upstream and downstream station differences rather than operation of the plant. The F-values shown are not significant owing to few replications but all of the large values are associated with the upstreamdownstream factor.

TABLE 41. Percent of Fish Collected by Seining in a Given Sampling Run

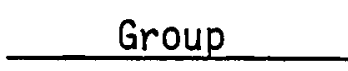

Shiners

Other Rough Fish

Game Fish
Preoperational $\frac{\text { Upstream }}{1} \frac{\text { Downstream }}{2}$

$89.4 \quad 57.3 \quad 76.2$

$8.6 \quad 41.5 \quad 23.4$

2.0

1.20 .4

Sum of Squares

\begin{tabular}{|c|c|c|c|c|}
\hline Source & $\underline{D F}$ & Shiners & Other Rough & Game \\
\hline $\operatorname{Preop}-0 p(A)$ & 1 & 2.41 & 1.50 & 0.07 \\
\hline Up-Down (B) & 1 & 391.02 & 461.28 & 2.901 \\
\hline Interaction $(A B)$ & 1 & 40.70 & 36.75 & 0.101 \\
\hline Residual & 2 & 203.11 & 183.65 & 0.565 \\
\hline$F_{A, A B}(1,1)$ & & 0.059 & 0.041 & 1.058 \\
\hline$F_{B, A B}(1,1)$ & & 9.607 & 12.552 & 28.769 \\
\hline$F_{A B, \text { Residua }]}(1,2)$ & & 0.398 & 0.400 & 0.357 \\
\hline
\end{tabular}


Creel Census

Creel census data were collected only for the operational years 1972 and 1973. The two types of information available from those studies included estimates of fishing pressure and an observation that 1973 fall fishing for smallmouth bass and walleye in the discharge canal exhibited higher catch rates 2.7 and $3.5 \mathrm{fish} / \mathrm{hr}$, respectively, than did the river areas during the regular May to October fishing season in the same year $(0.24$ and $0.10 \mathrm{fish} / \mathrm{hr})$. Since no estimate was made for the "normally" fished areas in the fall of 1973 and because the source of the fall canal fish is unknown, a conclusion that a new sports fishery has been established may be premature.

\section{Impingement and Entrainment}

Data reported for impingement and entrainment are in Tables 42 and 43 , respectively. In addition, we recorded the day of the week when each datum was obtained. These are further summarized in Tables 44 and 45 where we show that samples were collected so that some days of the week were never sampled whereas others were sampled frequently. If power demand patterns and associated reactor operation levels are very different for weekends, other days, or periods of days, then the data in Tables 42 and 43 may be biased if used to calculate results for any other period(s). In addition, sampling intervals were not the same over the study periods (see Table 44) which may introduce a further complication unless "steady state" catch conditions exist. We have prepared Figures 39 and 40 to show that for both entrainment and impingement data, captures per day are erratic and probably seasonal; and that comparable samples may be the only way to obtain reliable yearly estimates of total numbers of impinged and entrained fish. With the exception of three sample dates, impinged fish totaled less than 100/day while over 100 fish were entrained on all sampling days (excluding suckers) with some values higher than 1000/day. However, it should be noted (footnote 2, Table 42) that gamefish were a large part of the impingement "catch" as opposed to the entrainment "catch". Impingement data were not available for spring-summer of 1973 or other large values might have been observed. 
TABLE 42. Interpolated (1) Fish Impingement
Data for 1973-1974

\begin{tabular}{|c|c|c|c|}
\hline & $\begin{array}{l}\text { Day of } \\
\text { Week }\end{array}$ & $\begin{array}{l}\text { Cumulative } \\
\text { Time (days) }\end{array}$ & $\begin{array}{l}\text { Number of } \mathrm{Fish}^{2} \\
\text { Impinged/day }\end{array}$ \\
\hline
\end{tabular}

(1973)

$7 / 11$

$7 / 25$

$7 / 30$

$8 / 10$

$8 / 24$

$9 / 14$

$9 / 28$

$10 / 16$

$10 / 24$

$11 / 9$

$11 / 20$

$12 / 6$

$12 / 12$

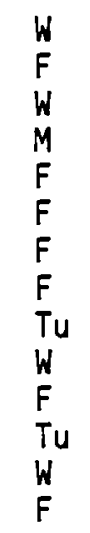

0
9
14

19

30

44

64

78

97

105

121

132

149

155

5
6
10
10
0
0
15
30
1200
75
62
18
19
18

(1974)

\section{$1 / 4$ \\ $1 / 18$}

$2 / 1$

$2 / 15$

$3 / 6$

$6 / 4$

$6 / 17$

$7 / 5$

$7 / 16$

$7 / 31$

$8 / 14$

$8 / 26$

$9 / 19$

$10 / 8$

$10 / 25$

$71 / 7$

$12 / 3$

$12 / 12$

$12 / 26$

$F$
$F$
$F$
$F$
$W$
$T u$
$M$
$F$
$T u$
$W$
$W$
$M$
$T h$
$T u$
$F$
$M$
$T u$
$T h$
$T h$
$T h$

178

192

206

220

239

323

336

354

365

380

394

406

430

449

466

479

503

512

526

8
14
5
0
60
340
18
8
38
35
35
410
15
5
18
10
10
12
12

(1) Interpolated from Figure 2, in Heberling, G.D., 1975, page 319.

(2) Smallmouth bass, black crappie, bluegill, and adult black bulinead made up 75.8 and $88.9 \%$ of the fish impinged in 1973 and 1974 , respectively. 


\section{TABLE 43. Field Fish Entrainment Data for 1973-1974}

\begin{tabular}{|c|c|c|c|c|c|c|}
\hline Date & $\begin{array}{l}\text { Day of } \\
\text { Week }\end{array}$ & $\begin{array}{l}\text { Cumulative } \\
\text { Time (days) }\end{array}$ & $\begin{array}{c}\text { Number of } \\
\text { Fish Entrained }\end{array}$ & $\begin{array}{l}\text { Fish Entrained } \\
\text { Hour } \\
\end{array}$ & $\begin{array}{l}\text { Estimated }(1) \\
\text { Total Fish/Day } \\
\text { Entrained } \\
\end{array}$ & $\begin{array}{c}\text { Estimated } \\
\text { Total Fish/Day } \\
\text { Entrained } \\
\text { Excluding Suckers } \\
\end{array}$ \\
\hline \multicolumn{7}{|l|}{ (1973) } \\
\hline $\begin{array}{l}9 / 12 \\
10 / 15 \\
10 / 22 \\
11 / 5 \\
11 / 19 \\
12 / 17\end{array}$ & $\begin{array}{l}W \\
M \\
M \\
M \\
M \\
M\end{array}$ & $\begin{array}{r}0 \\
33 \\
40 \\
54 \\
68 \\
96\end{array}$ & $\begin{array}{r}7 \\
18 \\
8 \\
3 \\
2 \\
9\end{array}$ & $\begin{array}{l}0.4 \\
1.7 \\
1.1 \\
0.5 \\
0.3 \\
1.5\end{array}$ & $\begin{array}{l}145 \\
523 \\
326 \\
127 \\
102 \\
385\end{array}$ & $\begin{array}{l}104 \\
523 \\
326 \\
127 \\
102 \\
385\end{array}$ \\
\hline \multicolumn{7}{|l|}{$(1974)$} \\
\hline $\begin{array}{l}1 / 18 \\
2 / 17 \\
3 / 13 \\
5 / 22 \\
5 / 30 \\
6 / 12 \\
6 / 20 \\
6 / 28 \\
7 / 14 \\
7 / 21 \\
7 / 28 \\
8 / 4 \\
8 / 18\end{array}$ & $\begin{array}{l}F \\
\text { Su } \\
W \\
W \\
T h \\
W \\
T h \\
F \\
\text { Su } \\
\text { Su } \\
\text { Su } \\
\text { Su } \\
\text { Su }\end{array}$ & $\begin{array}{l}128 \\
158 \\
182 \\
252 \\
260 \\
273 \\
281 \\
289 \\
305 \\
312 \\
319 \\
326 \\
340\end{array}$ & $\begin{array}{r}7 \\
1 \\
1 \\
156 \\
807 \\
4069 \\
55 \\
740 \\
65 \\
33 \\
32 \\
30 \\
3\end{array}$ & $\begin{array}{r}1.2 \\
0.2 \\
0.3 \\
86.7 \\
350.9 \\
1356.3 \\
110.0 \\
123.3 \\
11818.0 \\
5.5 \\
5.3 \\
5.0 \\
0.5\end{array}$ & $\begin{array}{r}275 \\
55 \\
61 \\
13104 \\
57262 \\
455728 \\
36696 \\
43216 \\
3886 \\
1795 \\
1728 \\
1644 \\
160\end{array}$ & $\begin{array}{r}235 \\
55 \\
61 \\
336 \\
142 \\
4928 \\
3336 \\
292 \\
2272 \\
1034 \\
378 \\
1096 \\
106\end{array}$ \\
\hline
\end{tabular}

SEASONAL SUMMARY

\begin{tabular}{|c|c|c|c|c|c|}
\hline \multirow[b]{2}{*}{ Period } & \multirow[b]{2}{*}{$\underline{n}$} & \multicolumn{2}{|c|}{ All Fish } & \multicolumn{2}{|c|}{ Excluding Suckers } \\
\hline & & Average Fish/Day & $\begin{array}{l}95 \% \text { Confidence } \\
\text { Value } \\
\end{array}$ & Average Fish/Day & $\begin{array}{l}95 \% \text { Confidence } \\
\text { Value } \\
\end{array}$ \\
\hline $\begin{array}{l}9 / 12 / 73-3 / 13 / 74 \\
5 / 22 / 74=6 / 28 / 74 \\
5 / 22 / 74=6 / 28 / 74^{\star} \\
7 / 14 / 74=8 / 18 / 74 \\
9 / 12 / 73=8 / 18 / 74\end{array}$ & $\begin{array}{r}9 \\
4 \\
5 \\
5 \\
19\end{array}$ & $\begin{array}{r}222 \\
37569 \\
121201 \\
1842 \\
32485\end{array}$ & $\begin{array}{r} \pm 125 \\
\pm 18840 \\
\pm 233005 \\
\pm 1188 \\
\pm 50060\end{array}$ & $\begin{array}{r}203 \\
106 \\
1807 \\
977 \\
833\end{array}$ & $\begin{array}{l} \pm 135 \\
\pm 2200 \\
\pm 2727 \\
\pm 1040 \\
\pm 629\end{array}$ \\
\hline
\end{tabular}

* Data of $6 / 12 / 74$ is included in $5 / 22 / 74-6 / 28 / 74$ period.

(1) See Knutsen, K.M., 1975, page 226 for calculations. 
TABLE 44. Examples of Sampling Bias in the Fish Impingement Program

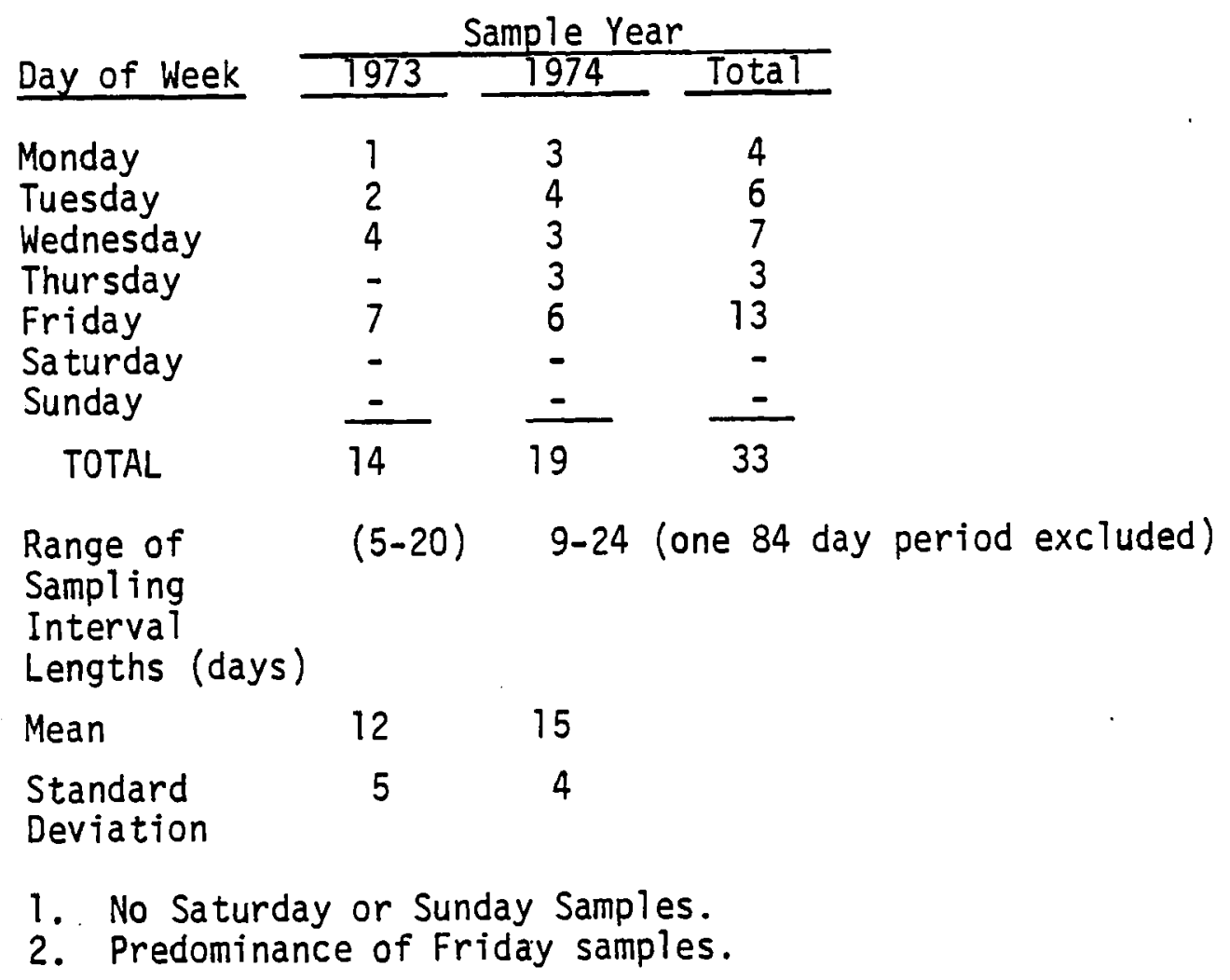
TABLE 45. Examples of Sampling Bias in
the Fish Entrainment Program

\begin{tabular}{|c|c|c|c|}
\hline \multirow[b]{2}{*}{ Day of Week } & \multicolumn{3}{|c|}{ Sample Year } \\
\hline & $\overline{1973}$ & 1974. & Tota 1 \\
\hline Monday & 5 & - & 5 \\
\hline Tuesday & - & - & - \\
\hline Wednesday & 1 & 3 & 4 \\
\hline Thursday & - & 2 & 2 \\
\hline Friday & - & 2 & 2 \\
\hline Saturday & - & - & - \\
\hline Sunday & - & 6 & 6 \\
\hline TOTAL & 6 & 13 & 19 \\
\hline
\end{tabular}

1. $79 \%$ of all samples were collected on Sunday, Monday, and Wednesday.

2. No samples on Tuesday or Saturday.

3. $10 / 15 / 73$ to $12 / 17 / 73$ all five samples were collected on Monday.

4. $7 / 14 / 74$ to $8 / 18 / 74$ all five samples were collected on Sunday. 


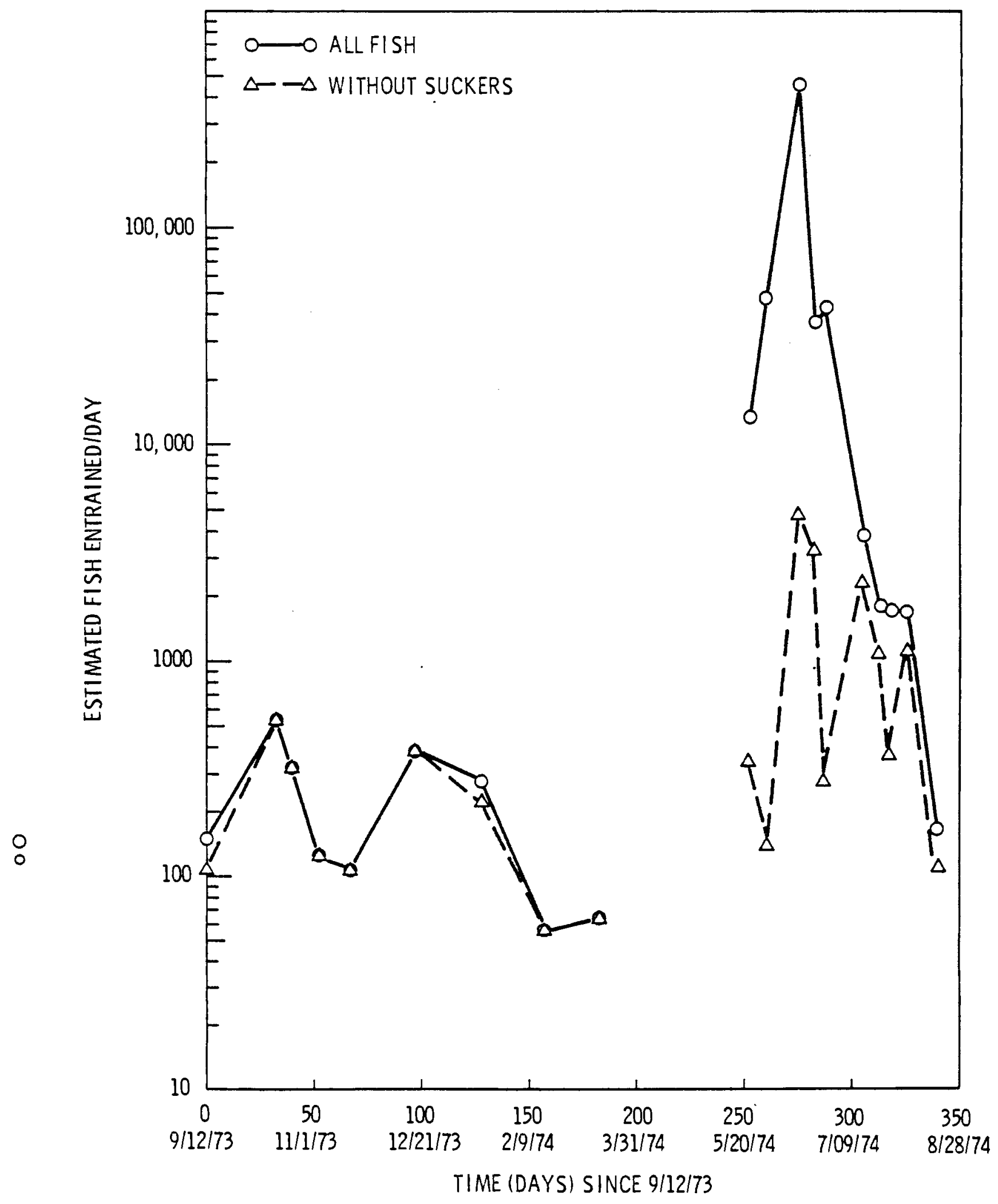

FIGURE 39. Fish Entrainment at Monticello 


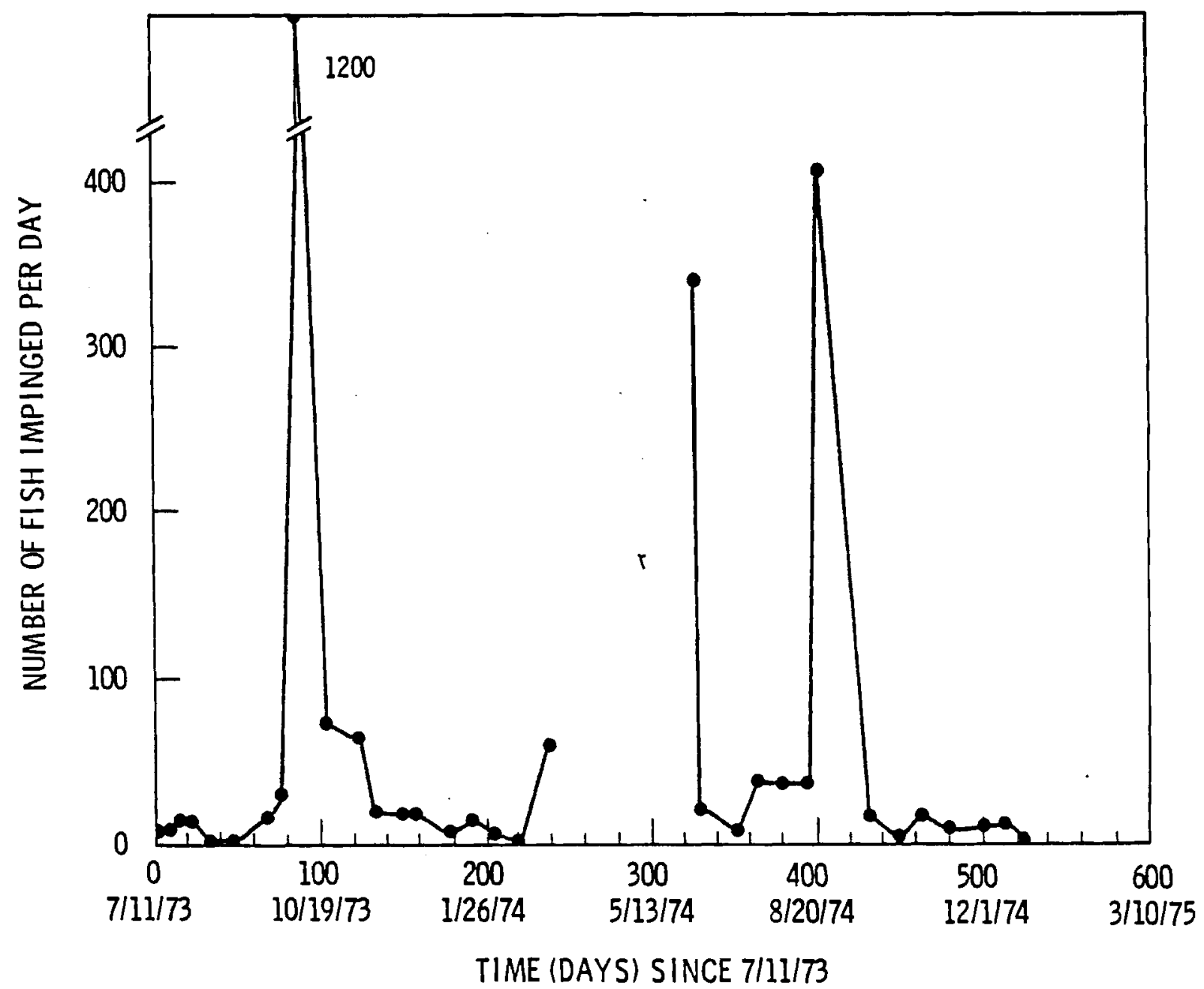

FIGURE 40. Fish Impingement at Monticel10

The seasonal summary at the bottom of Table 43 illustrates the shortcomings of attempting to estimate numbers of fish lost to impingement or entrainment using the available data. We have averaged estimates of total fish entrained per day, both including and excluding suckers, (suckers account for $96.8 \%$ of the numbers captured) over several time periods and have excluded one very high value in one calculation. Obviously, the estimates of average fish entrained per day are quite different, variable (see $95 \%$ confidence values), and sensitive to the occassional extreme observations. 
Time series analysis of data sets where several years of data are available has been suggested to circumvent some of the problems indicated above. Moreover, weighted averages (where sampling intervals differ substantially) might provide more accurate daily estimates which can be summed for yearly estimates. This procedure would also circumvent selecting seasons (periods) such as we attempted in Table 43. For example, our calculated daily estimate for the $9 / 12 / 73$ to $8 / 10 / 74$ period is 6029 fish per day rather than 32,485 fish per day found as a simple average. All the above procedures cannot provide a completely reliable estimate of total fish impinged or entrained by a power plant unless samples are collected daily, at least during times when large fluctuations in catches can be expected.

\section{Cold Shock}

Estimates of winter fish populations residing in the discharge canal, estimates of mortality for various fish species after a defined and controlled drop in winter discharge canal temperature to ambient, and an estimate of species numbers in the river in winter, "near" the canal would be necessary to assess the fractions of fish populations affected by cold shock. We believe the river fish population estimates devised using 1969 data (see section on electroshocking above) are both poor and inappropriate (displaced too far in time) to use as an aid in estimating cold shock effects. Further, we have located two different sets of canal population estimates (p. 326, footnote, Table 14 and in an unpublished document from the Northern States Power Company). Finally, estimates of field mortality due to rapidly falling temperatures were based on from 1 to 6 fish species, observed for 42 hours after cold shock. For these reasons we believe that calculation of estimates of cold shock losses may be subject to criticism.

\section{Summary}

We have qualitatively evaluated fish capture data obtained by electrofishing, seining, and two separate creel census. In addition, impingement, entrainment, and cold shock studies were evaluated. We were unable to quantitatively assess the data for changes due to the operation of the 
plant. The specific reasons for this failure are in the appropriate sections. No account was taken of the fact that fish may be able to "avoid" certain stressors in any of the above studies. 


\section{LITERATURE CITED}

Asbury, J. G. and A. A. Frigo. 1971. A Phenomenological Relationship for Predicting the Surface Areas of Thermal Plumes in Lakes. Argonne National Laboratory, Report No. ANL/ES-5.

Britt, N. W. 1955, New Methods of Collecting Bottom Fauna from Shoals or Rubble Bottoms of Lakes and Streams. Ecology 36: 524-525.

Bu11, C. J. 1968. A Bottom Fauna Sampler for Use in Stony Streams. Prog. Fish Cult. 30, 2:119-120.

Chayes, Felix. 1971. Ratio Correlation, a Manual for Students of Petrology and Geochemistry. The University of Chicago Press. Chicago, IL.

Eberhardt, L. L. 1976. Quantitative ecology and impact assessment. Jour. Environ. Mgmt., 4:1-44.

Eberley, Lee W. 1975. Spawning Activities of Major Fish Species in the Monticel10 Area of the Mississippi River. Master's Thesis, St. Cloud State College, $80 \mathrm{pp}$.

Edinger, J. E. and E. M. Polk. 1969. Initial Mixing of Thermal Discharge into a Uniform Current. National Center for Research and Training in Hydrologic and Hydraulic Aspects of Water Pollution Control. Report No. 1, Department of Environmental and Water Resource Engineering. Vanderbilt University, Nashville, TN.

Grzenda, A. R. and M. L. Brehmer. 1960. A Quantitative Method for the Collection and Measurement of Stream Periphyton. Limnol. and Oceanogr. 5 , 190.

Guenther, W. C. 1964. Analys is of Variance. Prentice Hall, Englewood Cliffs, NJ, p. 131.

Herberling, G. D. and J. W. Weinhold. 1975. Fish impingement, In:

Environmental Monitoring and Ecological Studies Program, 1974 Annual Report.

For the Monticello Nuclear Generating Plant, Northern States Power Co., Minneapolis, MN, pp. 309-327.

Hopwood, A. J. 1970. Monticello ecological monitoring program, a progress report covering 1969.. In: Northern States Power Company Environmental Monitoring Program Annual Report 1969, Northern States Power Co., Minneapol is, MN, p. 116.

Hopwood, A. J. 1974a. Monticello ecological studies program, a progress report covering 1973. In: Northern States Power Company Environmental Monitoring and Ecological Studies Program, 1973 Annual Report. Northern States Power Co., Minneapolis, MN, pp. 229-311. 
Hopwood, A. J. 1974b. Thermal effects of a nuclear power plant on the Mississippi River at Monticello, Minnesota. Water Resources Research Center Bulletin, No. 69, p. 133.

Knutson, K. M. 1973. Attached algae studies on the Mississippi River at Monticello during 1972, a progress report covering 1972. In: Northern States Power Company Environmental Monitoring and Ecological Studies Program, 1972 Annual Report, Northern States Power Co., Minneapolis, MN, pp. 419-556.

Knutson, K. M. 1975. Pumped entrainment of small fish at Monticello Nuclear Generating Plant on the Mississippi River, 1973-1974. In: Environmental Monitoring and Ecological Studies Program, 1974 Annual Report. For the Monticello Nuclear Generating Plant, Northern States Power Co., Minneapolis, MN, pp. 209-233.

Koh, R. C. Y. and L. N. Fan. 1970. Mathematical Models for the Prediction of Temperature Distributions Resulting from the Discharge of Heated Water in Large Bodies of Water. EPA Water Pollution Control Research Series, 16130 DWO.

Lorenzen, C. J. 1967. Determination of Chlorophyll and Pheo-Pigments: Spectrophotometric Equations. Limnol. and Oceanogr. 12, 343-346.

Matter, William J. 1975. Invertebrate Drift in the Mississippi River Near Monticello, Minnesota. Master's Thesis, St. Cloud State College, 73 pp.

Ricker, W. E. 1975. Computation and interpretation of biological statistics of fish populations. Bull. Fish. Res. Board Can. 191: 382 pp.

Thomas, J. M. and L. L. Eberhardt. 1975. Problems using dose-response curves in setting environmental standards. In: Pacific Northwest Laboratory Annual Report for 1974. BNWL-1950, Pt. 2. Battelle-Northwest, Richland, WA, PP. 16-18.

Thomas, J. M. , L. L. Eberhardt, S. D. Zellmer and H. A. Hawthorne. 1976. Cesium-strontium ratios in an intensive study of fallout. In: Radioecology and Energy Resources, Fourth National Radioecology Symposium, C. E. Cushing (ed.). Dowden, Hutchinson \& Ross, Inc., Stroudsburg, PA.

Tukey, J. W. 1976. Exploratory Data Analysis. John Wiley \& Sons, New York, NY.

USAEC, Directorate of Licensing. 1972. Final Environmental Statement Related to Operation of Monticello Nuclear Generating Plant. Northern States Power Co., Docket No. 50-263. 


\section{REFERENCES}

Amer. Public Health Assoc. 1960. Standard Methods for the Examination of Water and Waste Water. 11 th Ed. Amer. Pub. Health Assoc., Amer Wat Wrks Assoc, Wat. Pol1. Cont. Fed., New York, NY.

Berguson, S. R., and K. M. Knutson. 1974. An assessment of entrainment on small fish, a progress report covering 1972-1973. In: Environmental Monitoring and Ecological Studies Program, 1973 Annual Report. Northern States Power Co., Minneapolis, MN, pp. 321-381.

Brook, A. J. 1971. Attached algae studies on the Mississippi River at Monticel10 - Interim Report 1971. In: Northern States Power Company Environmental Report. Monticello Nuclear Generating Plant, Northern States Power Co., Minneapolis, MN, P. 4 plus figures.

Brook, A. J. 1970. Attached algae studies of the Mississippi River at Monticello, Minnesota. In: Northern States Power Company Environmental Monitoring Program Annual Report 1969. Northern States Power Co., Minneapolis, MN, P. 11 plus figures.

Colingsworth, R. F. 1969. Attached algae studies on the Mississippi River at Monticello, Minnesota, an annual report covering 1968. In: Northern States Power Company Environmental Monitoring Program Annual Report 1968. Northern States Power Company, Minneapolis, MN, 12 p.

Grotbeck, L. M. 1974. Winter Rapid-Trip Simulation Experiments with Estimation of Fish Cold Shock Mortality at the Monticello Nuclear Plant. Northern States Power Co., Minneapolis, MN, 20 p.

Heberling, G. D. 1975. A summary of growth and abundance data of selected young-of-the-year fish species in the Mississippi River near the Monticello Nuclear Generating Plant. In: Environmental Monitoring and Ecological Studies Program, 1974 Annual Report. For the Monticello Nuclear Generating Plant, Northern States Power Co., Minneapol is, MN, Pp. 273-307.

Hopwood, A. J. 1969. Monticello ecological monitoring program, a report covering 1968. In: Northern States Power Company Environmental Monitoring program annual Report 1968, Northern States Power Co., Minneapolis, MN, p.28.

Hopwood, A. J. 1971. Monticello ecological monitoring program, a progress report covering 1970. In: Northern States Power Company Environmental Monitoring Program Annual Report 1970. Northern States Power Co., Minneapolis, MN, P. 128.

Hopwood, A. J. 1972. Monticello ecological studies program, a progress report covering 1971. In: Northern States Power Company Environmental Monitoring and Ecological Studies Program, 1971 Annual Report, Northern States Power Co., Minneapolis, MN, P. 42. 
Hopwood, A. J. 1973. Monticello ecological studies program, a progress report covering 1972. In: Northern States Power Company Environmental Monitoring and Ecological Studies Program, 1972 Annual Report. Northern States Power Co., Minneapolis, MN, pp. 305-418.

Hopwood, A. J. 1975. Monticello ecological studies program, a progress report covering 1974. In: Northern States Power Company Environmental Monitoring and Ecological Studies Program, 1974 Annual Report. For the Monticello Nuclear Generating Plant, Northern States Power Co., Minneapolis, MN, pp. 125-205.

Knutson, K. M. 1974a. Attached algae studies on the Mississippi River at Monticello during 1973, a progress report covering 1973. In: Northern States Power Company Environmental Monitoring and Ecological Studies Program, 1973 Annual Report, Northern States Power Co., Minneapolis, MN, pp. 383-571.

Knutson, K. M. 1974b. Natural entrainment of small fish from the Mississippi River at Monticello during 1973-1974, a progress report covering 1973-1974. In: Northern States Power Company Environmental Monitoring and Ecological Studies Program, 1973 Annual Report. Northern States Power Co., Minneapolis, MN, Pp. 297-319.

Knutson, K. M. 1975. Attached algae studies on the Mississippi River at Monticello during 1974, a progress report covering 1974. In: Northern States Power Company Environmental Monitoring and Ecological Studies Program, 1974 Annual Report. For the Monticello Nuclear Generating Plant, Northern States Power Co., Minneapol is, MN, pp. 41.

McConvilile, D. R. 1972. Population Dynamics of the Macroinvertebrates in the Mississippi River Near Monticello, Minnesota. Ph.D. Thesis, University of Minnesota, $184 \mathrm{p}$.

Neuhold, J. M. and K. H. Lu. 1957. Creel Census Method. Utah State Dept. Fish Game. Salt Lake City, UT, Publ. No. 8.36 pp.

Northern States Power Company. 1972. Monticello Nuclear Generating Plant Environmental Report, Docket No. 50-263.

Northern States Power Company. 1972. Monticello Nuclear Generating Station Environmental Report, Supplement I, Northern States Power Co., Minneapolis, MN, Docket No. 50-263.

Northern States Power Company, Environmental Science Services Section. 1974. Water analyses, physical and chemical. In: Northern States Power Company Environmental Monitoring and Ecological Studies Program, 1973 Annual Report. Northern States Power Co., Minneapolis, MN, pp. 513-531. 
Northern States Power Company, Environmental Science Services Section. 1973. Water analyses, physical and chemical. In: Northern States Power Company Environmental Monitoring and Ecological Studies Program, 1974 Annual Report. For the Monticello Nuclear Generating Plant, Northern States Power Co., Minneapolis, MN, pp. 13-36.

Northern States Power Company, Environmental Science Services Section. 1973. Water analyses, physical and chemical. In: Northern States Power Company Environmental Monitoring and Ecological Studies Program, 1972 Annual Report. Northern States Power Co., Minneapolis, MN, pp. 309-345.

Northern States Power Company. Draft Environmental Technical Specifications, Appendix B to Facility Operating License no. DPR-22. Northern States Power Co., Docket No. 50-263. 


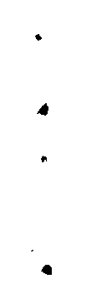




\title{
APPENDIX A
}

\section{ENVIRONMENTAL TECHNICAL SPECIFICATIONS} APPENDIX B

\section{TO}

\author{
FACILITY OPERATING LICENSE NO. DPR-22 \\ for \\ MONTICELLO NUCLEAR GENERATING PLANT \\ UNIT 1 \\ NORTHERN STATES POWER COMPANY \\ DOCKET NO. 50-263
}



3.0 ENVIRONMENTAL SURVEILLANCE

3.1 Nonradiological Surveiliance

3.1.1 Aquatic

General Ecological Survey

Objective

To evaluate the impact of the facility on the biotic environment.

Specification

1. Investigate any changes in the biota that may occur by comparing preoperational data to operational data and control stations to experimental stations.

2. Identify any change in the ecosystem induced by plant operation.

3. Evaluate significance of induced changes, if any, on sustenance of a healthy ecosystem as determined in preoperational studies or as defined by regulatory standards.

Basis

A general ecological survey was initiated in May 1968, 3 years prior to the beginning of plant operation in June 1971. This program has been extensively expanded since its inception. Information gathered from preoperational environmental studies was published in the 1968, 1969 and 1970 Monticello Nuclear Generating Plant Annual Environmental Monitoring and Ecological Studies Program Reports.

1. The program may be modified as necessary to accommodate sampling requirement changes. This program has been continually reviewed and reevaluated since its conception. After 60 months of data have been obtained from the beginning of commercial operation, some of the special studies in Section TS B-3.0 may be eliminated if the results of these studies are conclusive and show no significant harmful environmental effects. 
2. These changes and results will be presented in the Annual Environmental Monitoring and Ecological Studies Program Report for the facility.

3. These studies are performed as follows: The program for aquatic ecological studies of the Mississippi River in the vicinity of the Monticello Nuclear Generating Plant has been designed to establish ecological characteristics prior to and during plant operation. Preoperational data are being compared with operational data to verify that the plant is not deleteriously altering the aquatic ecosystem. This study began 3 years prior to plant operation and will continue until specific effects of the plant can be determined and the data show a stabilized aquatic environment. Studies are organized to investigate the aquatic biota and the physical and chemical composition of the environment.

Species are identified and their population and size are determined. Food habits and reproductive cycles of dominant species are studied whenever possible. Due to the seasonal fluctuations of these factors, most sampling programs are carried out on a scheduled year-round basis. It should be noted that this program is designed to remain flexible, so that changes can be made immediately if required. Factors studied are:

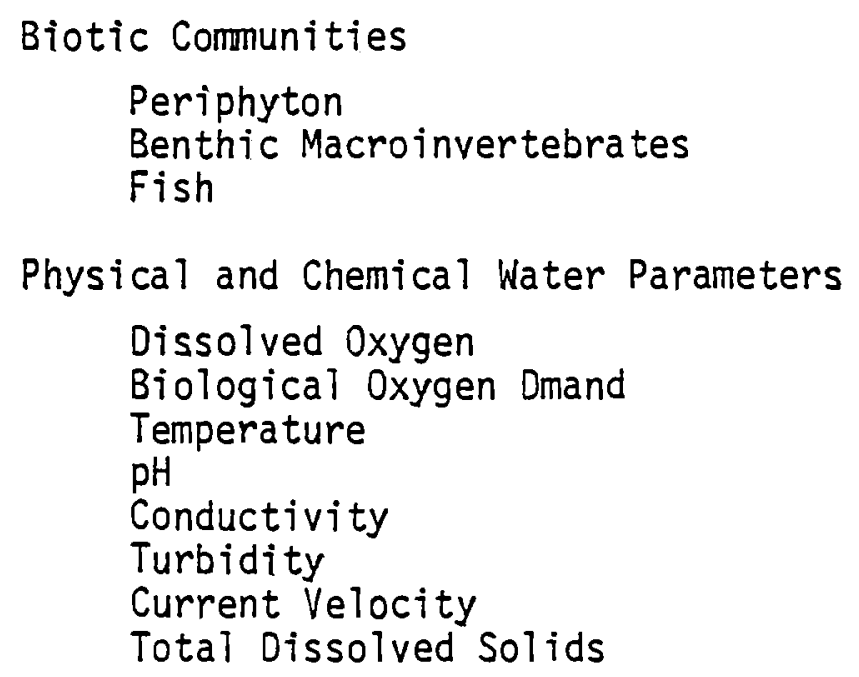


Total Alkalinity

Total Phosphate

Ortho-phosphate

Nitrate Nitrogen

Chlorides

Iron

Sulfates

Basic Procedures for These Studies Are:

a. Periphyton

Periphyton sampling was initially conducted at 13 locations at the Monticello facility. Comparison of 3 years of preoperational studies with 3 years of operational indicate that only 5 stations are required to monitor any changes that may occur in species diversity, abundance and chlorophy 11 content due to the plant effluent. The locations are shown in Figure TS-B.4.1.1. There is 1 control station upstream of the discharge canal. One of the downstream stations is outside the thermal plume. Samples are analyzed every 2 weeks except when flooding destroys samplers or hazardous ice conditions exist.

b. Benthic Macroinvertebrates Study

Three years of preoperational and 3 years of operational studies have shown that there have been no significant changes in species diversity or abundance. Because of this the program has been reduced to one upstream control transect $\mathrm{C}-2$ (Figure TSB 4.1.1-2) and one downstream experimental transect E-2 (Figure TSB-4.1.1-2). The experimental transect is located $75 \mathrm{~m}$ downstream from the point of discharge. This transect serves as a reliable indicator of changes in species abundance and/or diversity that may occur due to plant discharges. Each transect consists of at least three stations spaced equidistant from each other. Four concrete block 
artificial substrates are located on the bottom at each station. These are removed monthly for enumeration, weighing and identification of colonized organisms. Some stations may not be sampled in the winter when unsafe ice conditions exist or when flooding removes sampling devices.

c. Fish

Electro-fishing and seining are the dominant methods used in the fish study. Trapnetting will be used in the future, as an additional sampling method. A representative sample of fish are measured and weighed with some scales removed for age and growth determinations. The fisheries data are used to determine changes in relative abundance and distribution due to the plant discharge. A creel census of the fishery is being conducted to determine quality of fishing. The census usually is conducted from May though November with the exact sampling time dependent upon angler presence.

A biweekly fish census will be conducted in the discharge canal during winter months to determine species distribution and abundance. This data wi11 be used to predict possible harm should a winter shutdown occur. This program will be conducted in accordance with the "Stipulation for Settlement of Contention II-23," dated October 23, 1974, between MPCA, NSP, and NRC Reg. staff.

3.1.2 Physical and Chemical Water Quality Parameters

The water quality study includes the physical and chemical parameters of water whish might affect aquatic life. The chemical factors studied and their frequency of measurement is as follows: 
Parameter

Dissolved Oxygen

Biological Oxygen Demand

Temperature

$\mathrm{pH}$

Conductivity

Turbidity

Current Velocity

Total Dissolved Solids

Total Phosphate

Ortho-phosphate

Nitrate Nitrogen

Chlorides

Iron

Sulfates
Frequency

Quarterly

Quarterly

Continuous at two locations

Quarterly

Quarterly

Quarterly

Quarterly

Quarterly

Quarterly

Quarterly

Quarterly

Quarterly

Quarterly

Quarterly

A subsurface sample of one gallon of water is taken from each of three stations. One station is located 1000 feet upstream of the intake structure, one is in the discharge canal and the downstream station is 1000 feet below the point of discharge to the river. Intake and discharge temperatures are measured continuously by the plant computer.

Impinged and Entrained Fauna

Objective

To determine monthly variations in species, size, and numbers, of all life stages of fish entrapped; to identify and count any other impinged vertebrates and to record that portion of the entrained fauna which is killed due to passage through the plant.

\section{Specification}

Impingement and entrainment studies shall be carried out for at least 2 years after the Appendix B Environmental Technical Specifications are in effect, after which results thus far obtained will be used as a basis for determining whether further studies 
or surveillance programs are warranted. Impingement studies shall be conducted every two weeks when the plant is operating. Entrainment studies shall be conducted from May through August for fish and May through October for aquatic insects. Results sha 11 be reported as per reporting as per requirements given in Section 5 of this document.

Data collected during plant operation will be compared with appropriate control station data, thereby providing information to help determine the effect of the plant upon the impinged and entrained biota.

Basis

1. Fish Impingement

Presently the plant is designed to return all impinged fish from the intake traveling screens to the river via low gradient sluice canal. Impinged fish are removed from the screens by periodic washings. A11 screen washed material is sampled by placing a $1 / 4$ inch mesh net in the sluice canal. Al1 fish collected will be identified, counted and a representative sample measured to determine monthly and seasonal trends in impingement and survivorship. Results will be reported as per reporting requirements described in Section 5 of this document.

2. Impingement of Other Vertebrates and Macroinvertebrates If aquatic or semi-aquatic vertebrates (such as salamanders, frogs and snakes) or macroinvertebrates (including crayfish and clams, but excluding insects) are impinged, they will be identified, counted and reported as per to reporting conditions described in Section 5 of this document.

3. Entrainment

a. Estimates on numbers of entrained ichthyoplankton, including organisms up to $3 / 8$ inch in diameter, shall 
be made monthly from May through August when peak numbers of fish - fry and eggs are present in the river. Since previous studies have shown no great diel variation in number of fish collected during the day, a representative sample for a day will be collected, identified and mortality determined.

b. Estimates on number and mortality of entrained aquatic insects will be performed monthly from May through October to coincide with high standing crop, drift rate, and growth periods. A representative subsample of the insects collected will be counted, identified and mortality estimates performed. 
4.0 SPECIAL SURVEILLANCE PROGRAM

(parenthetical for Board's information)

(In accordance with the "Stipulation for Settlement of Contention II-23", dated October 23, 1974, MPCA, NSP, and AEC Regulatory staff, a special program of monitoring and data evaluation in the discharge canal will be conducted. A copy of the stipulation has been made available to all parties.) 


\section{APPENDIX B}

\section{MONTHLY AVERAGE EXCESS BOTTOM TEMPERATURES}





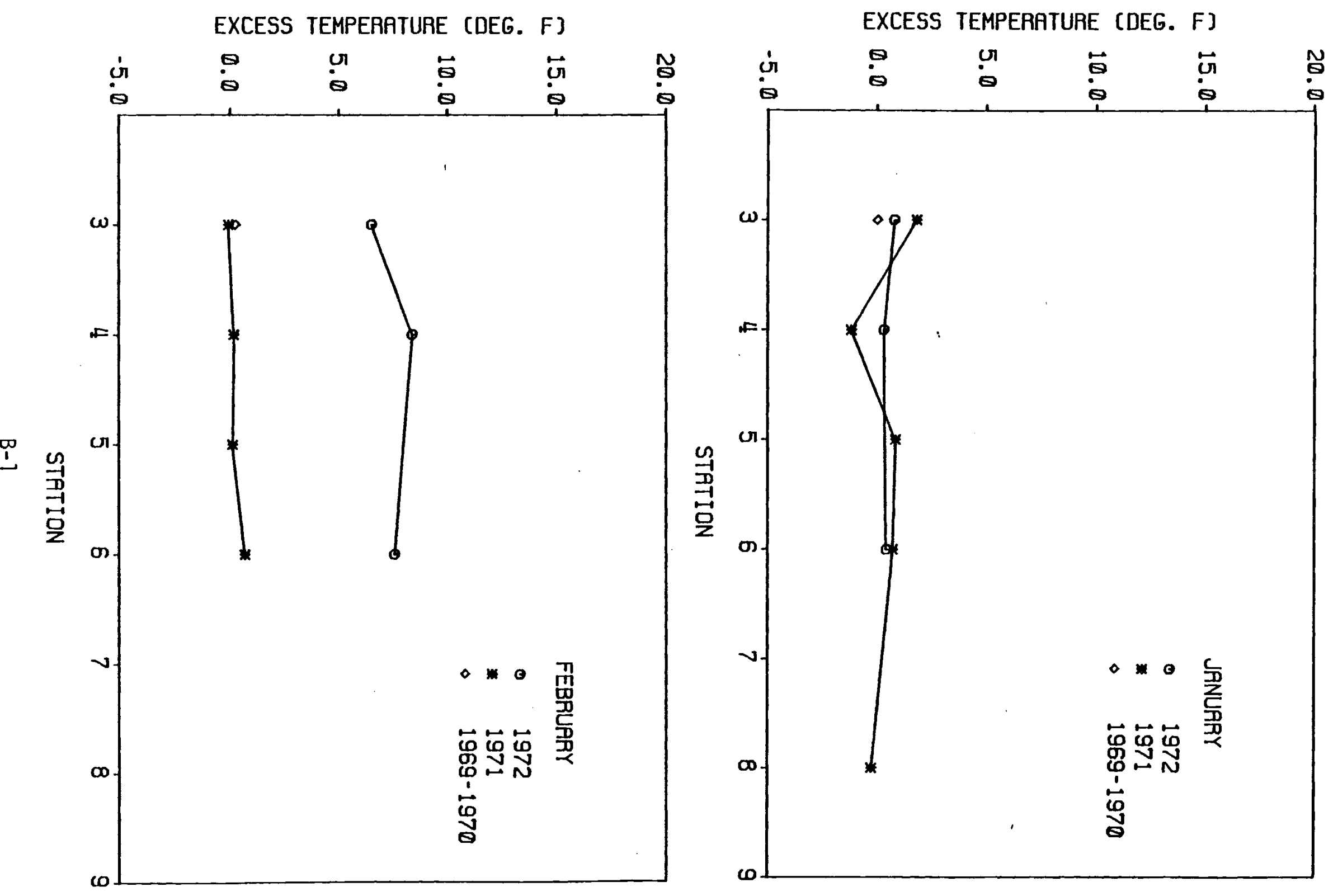



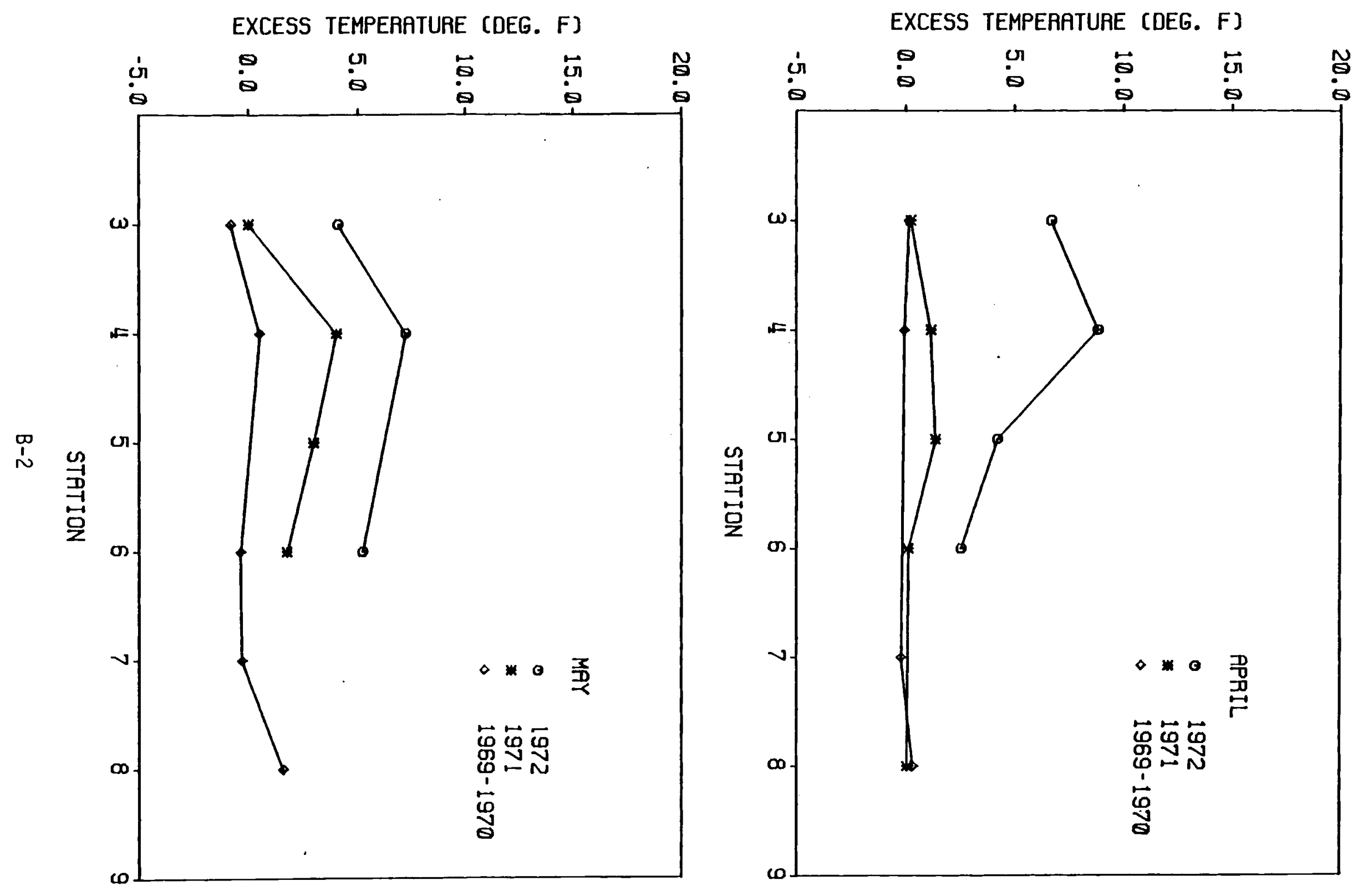

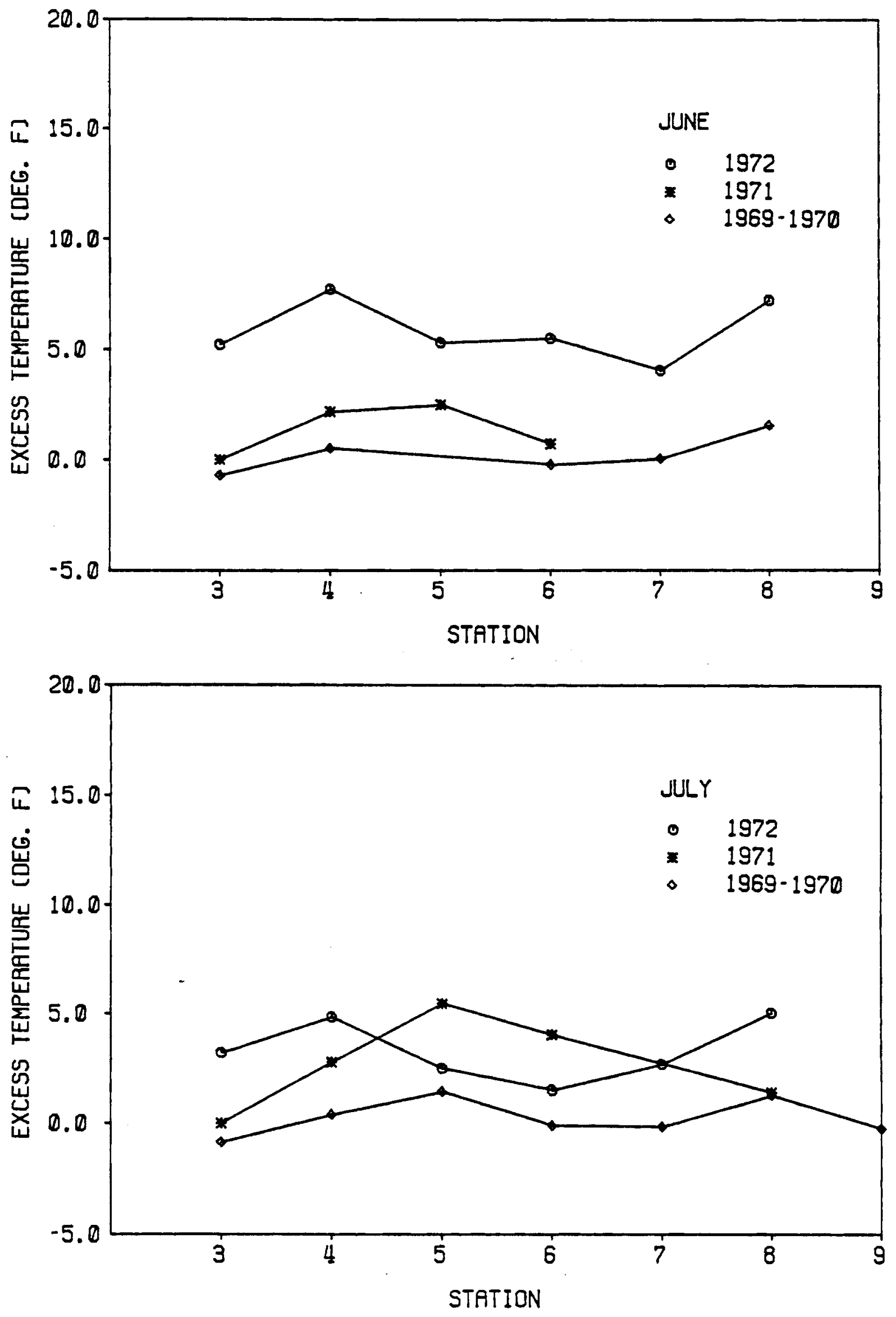

B-3 

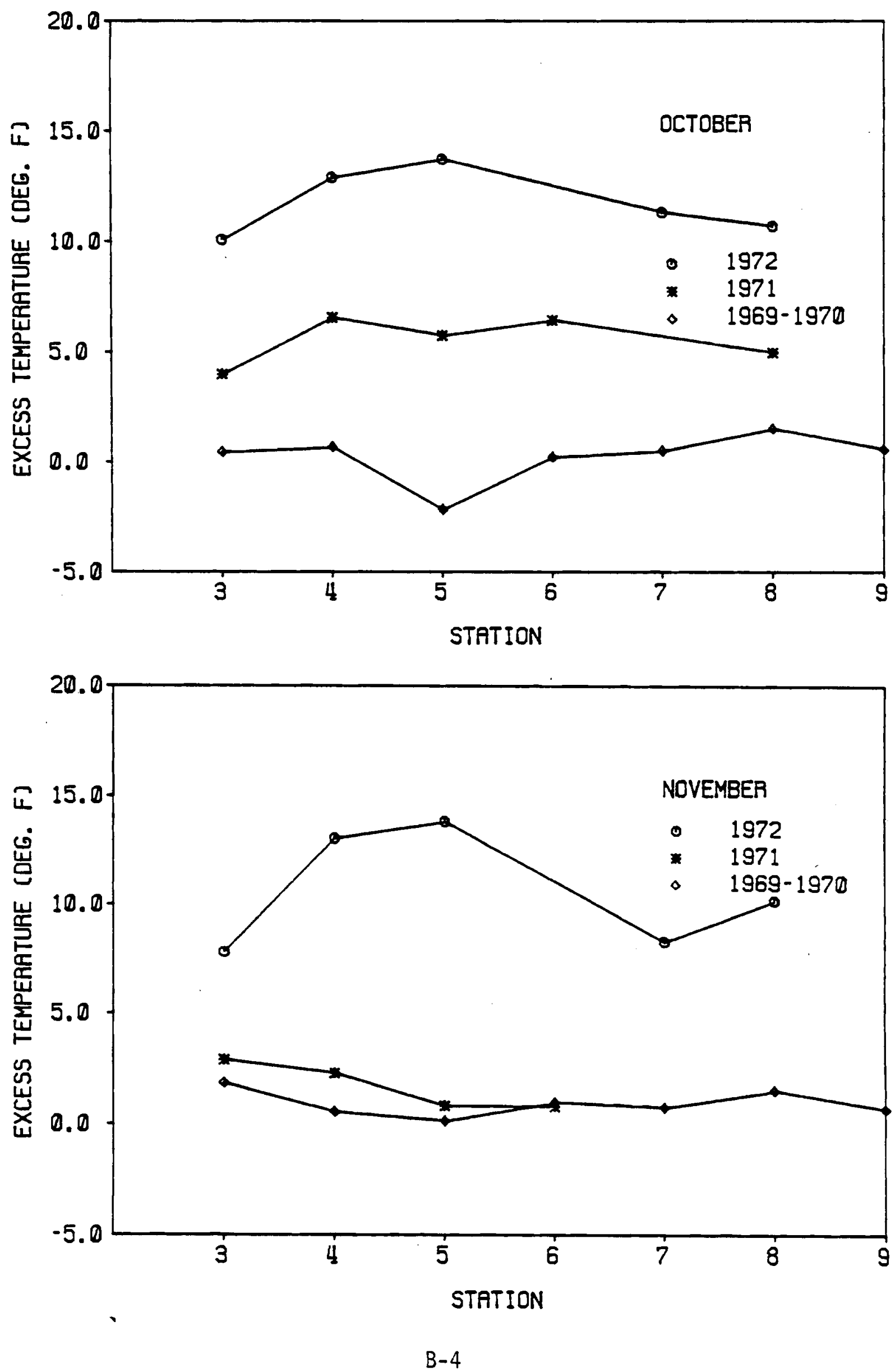


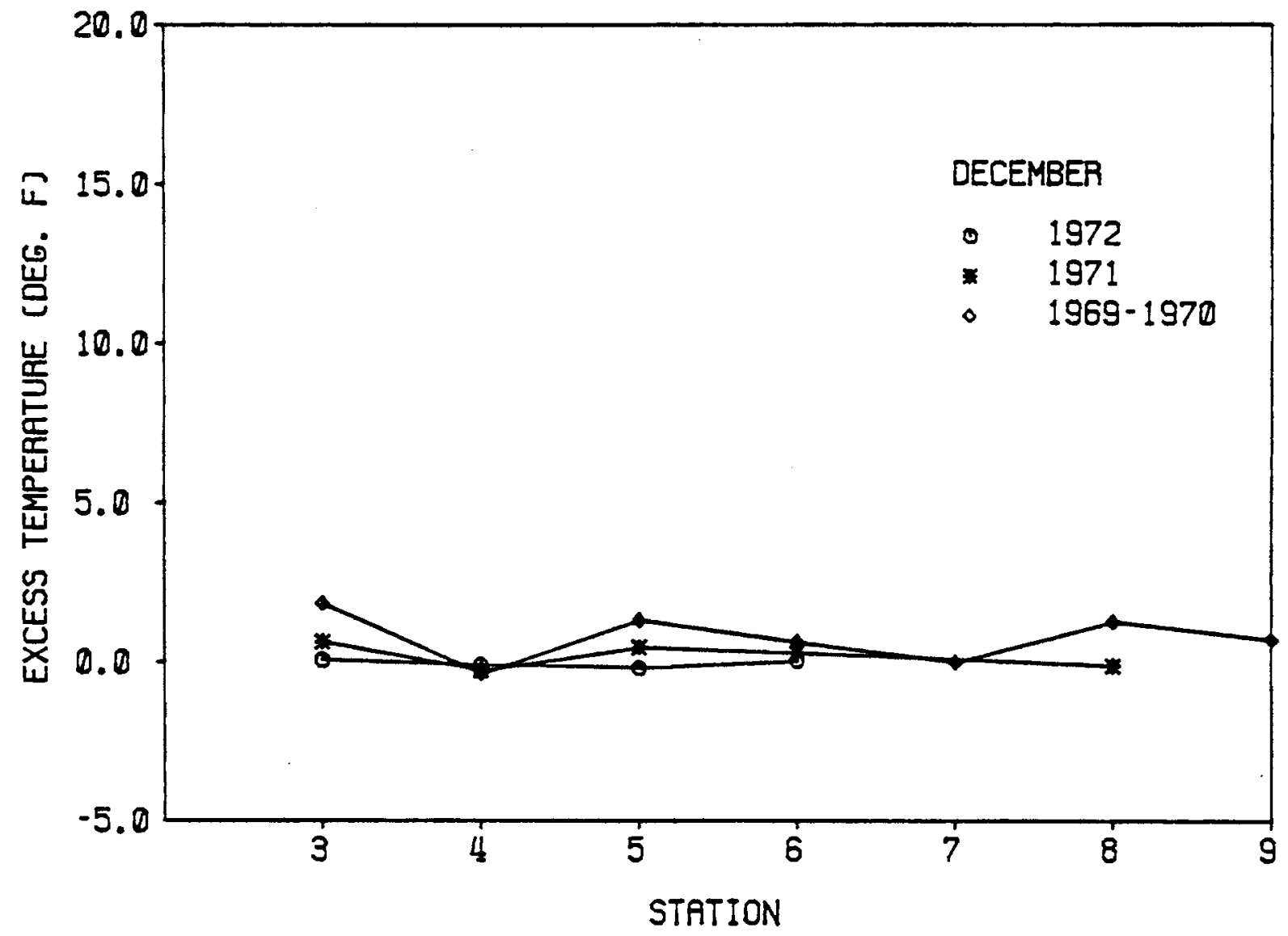




\section{APPENDIX C}

ORIGINAL BENTHOS DATA 



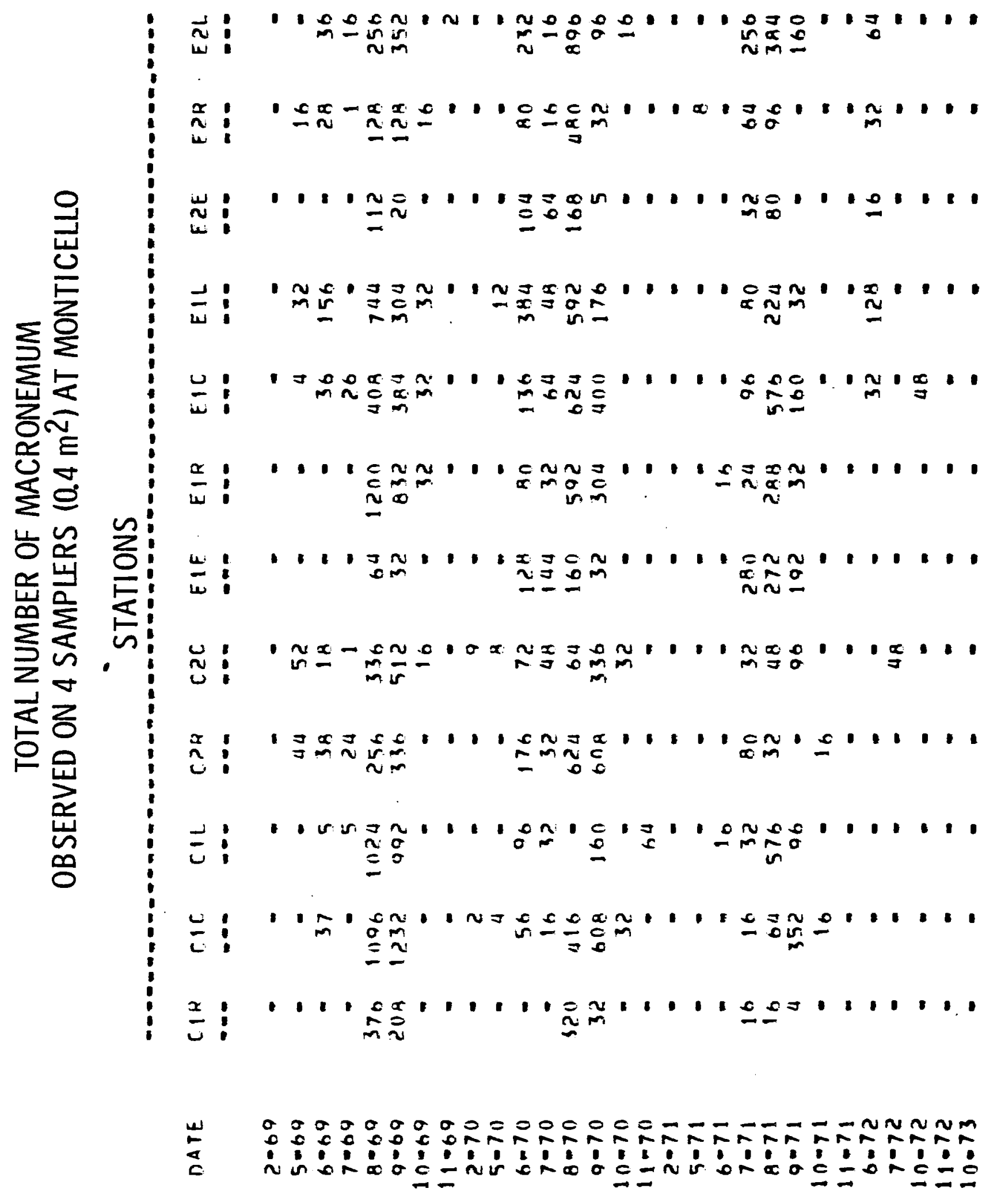




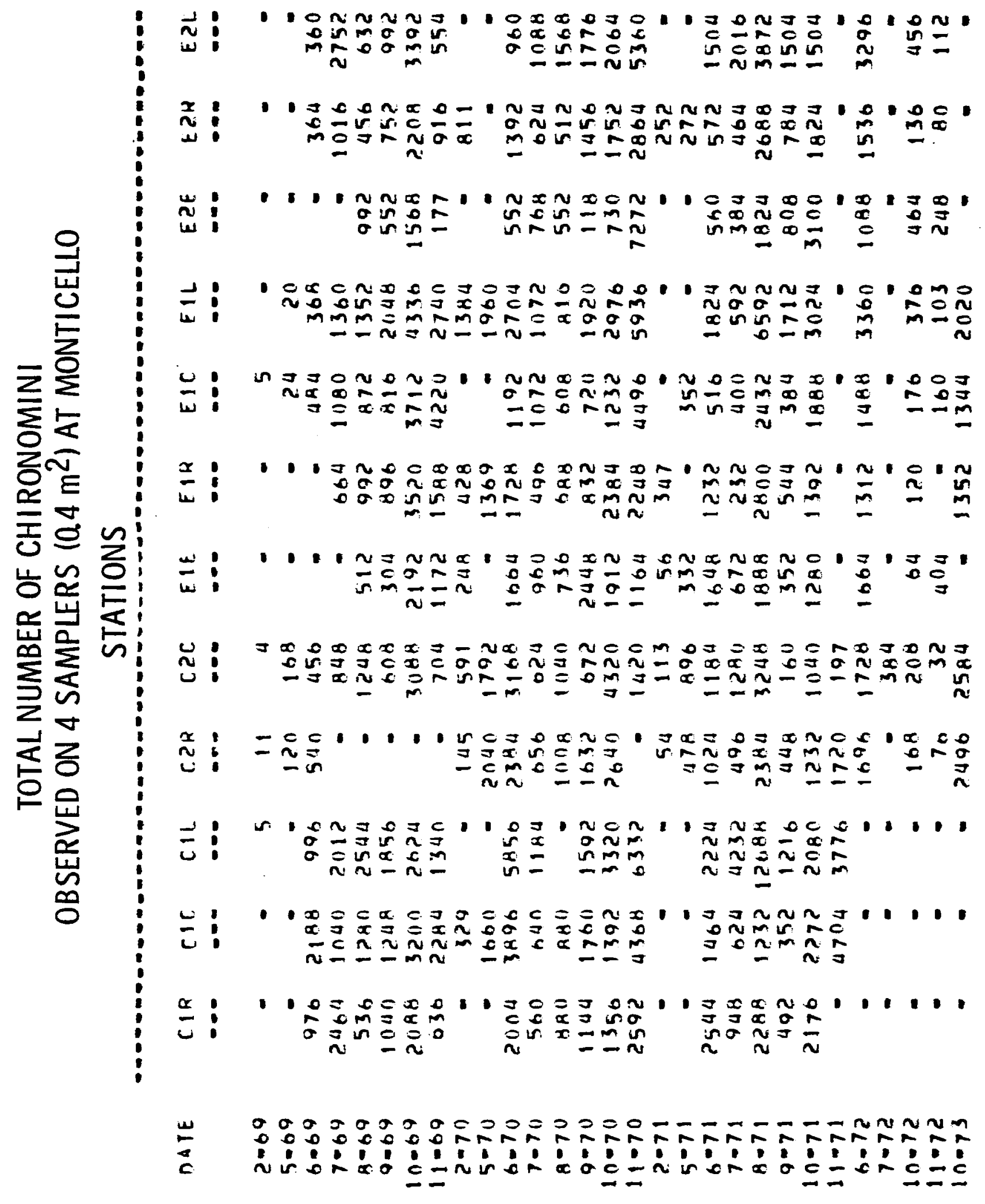




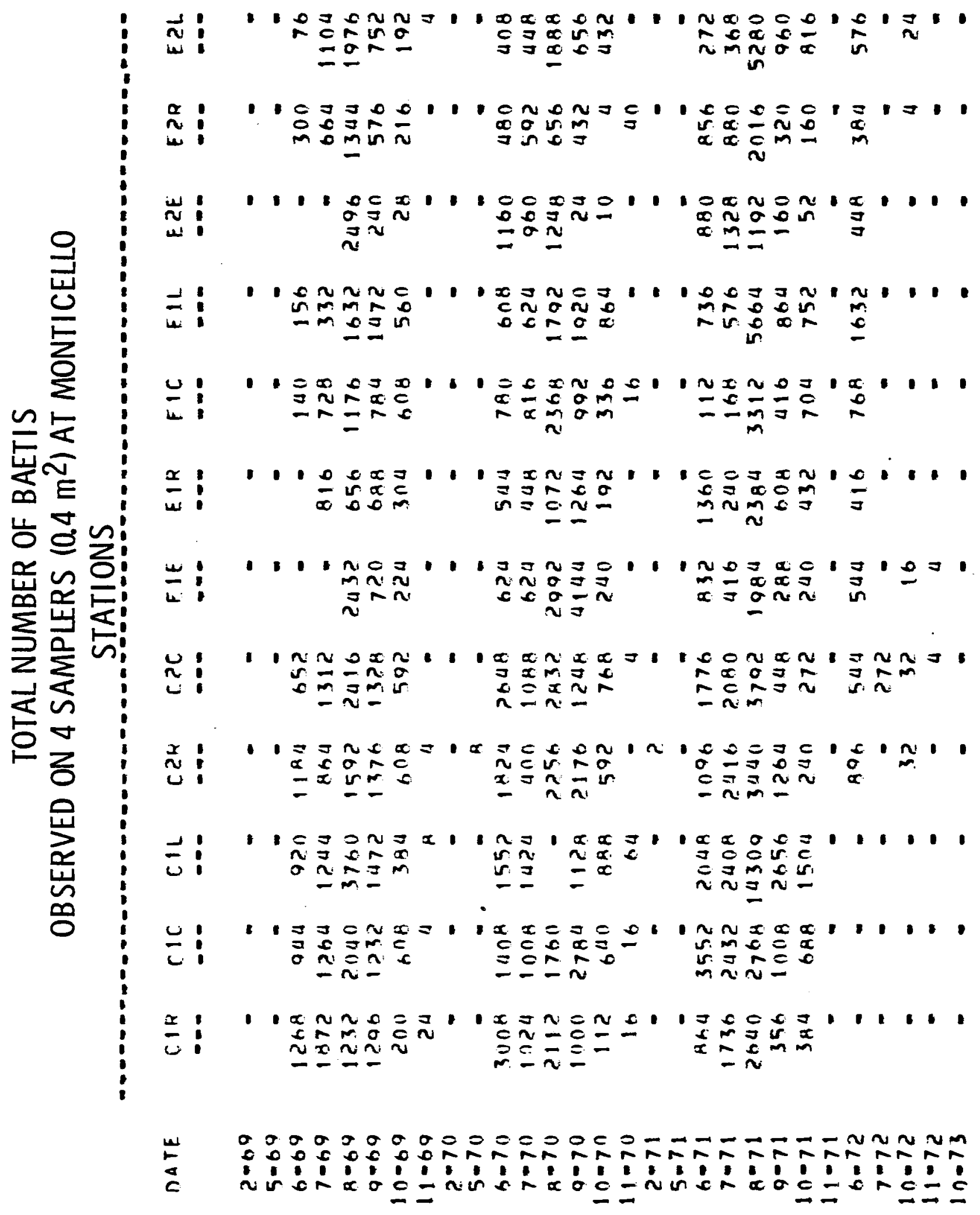




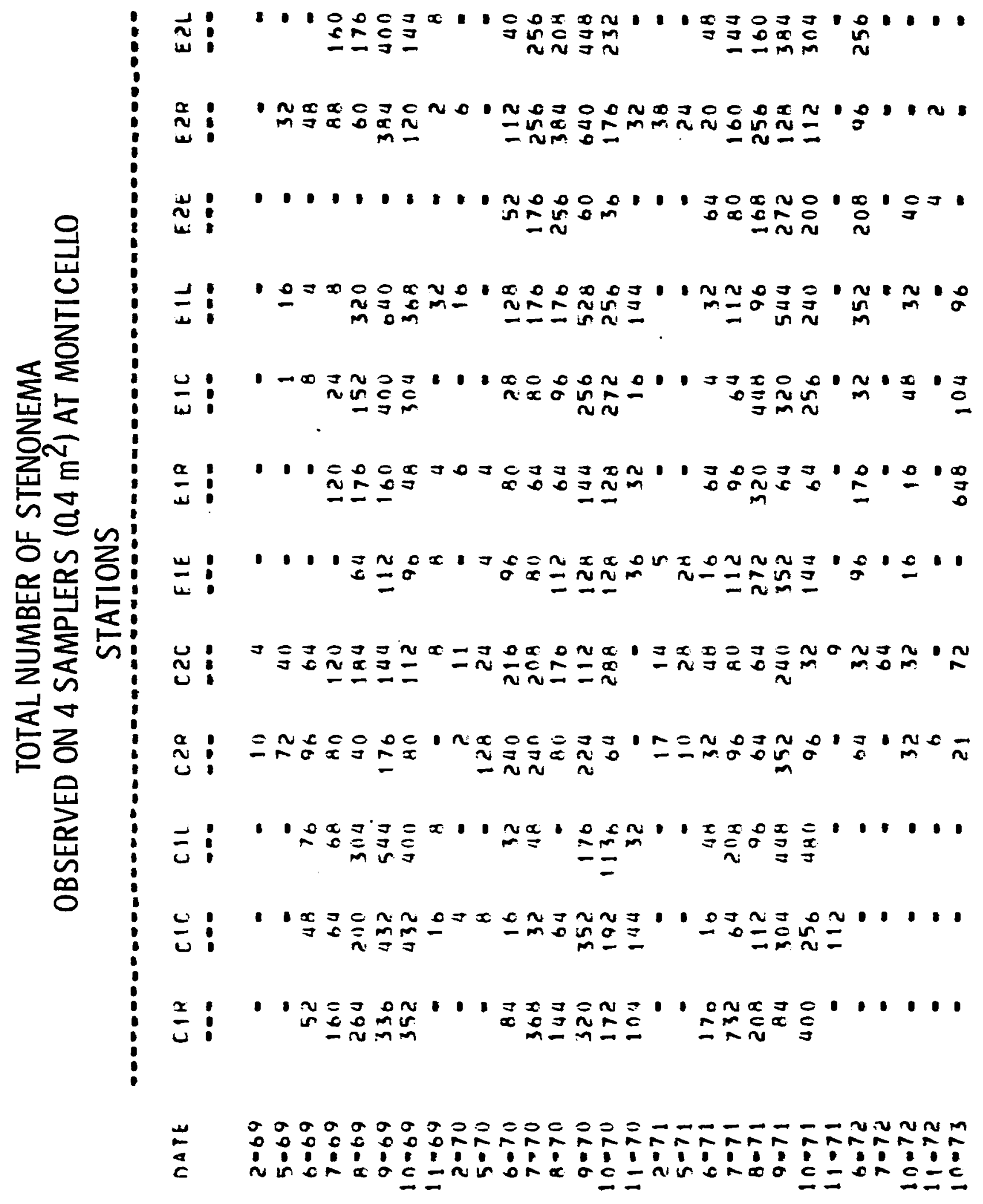




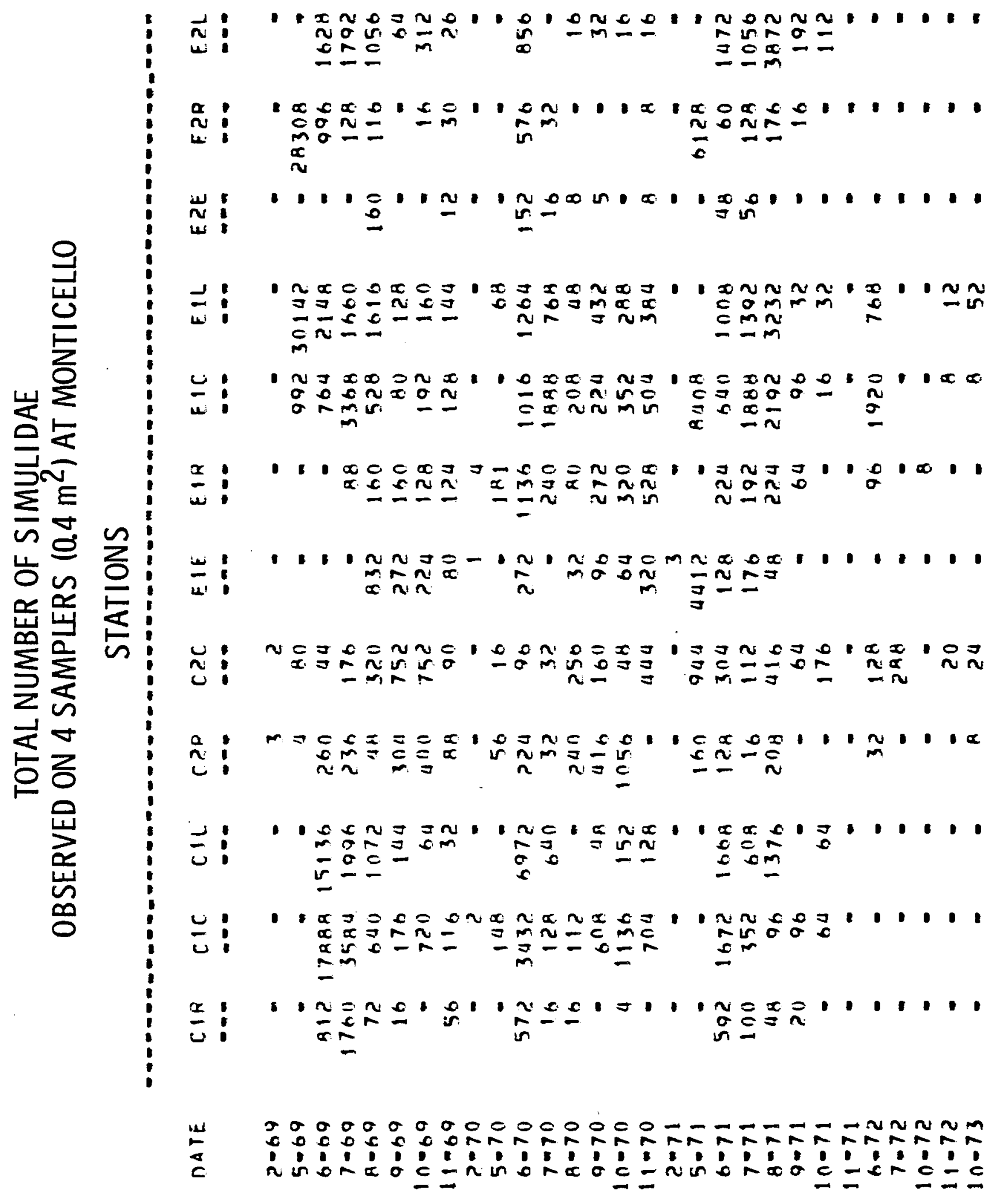




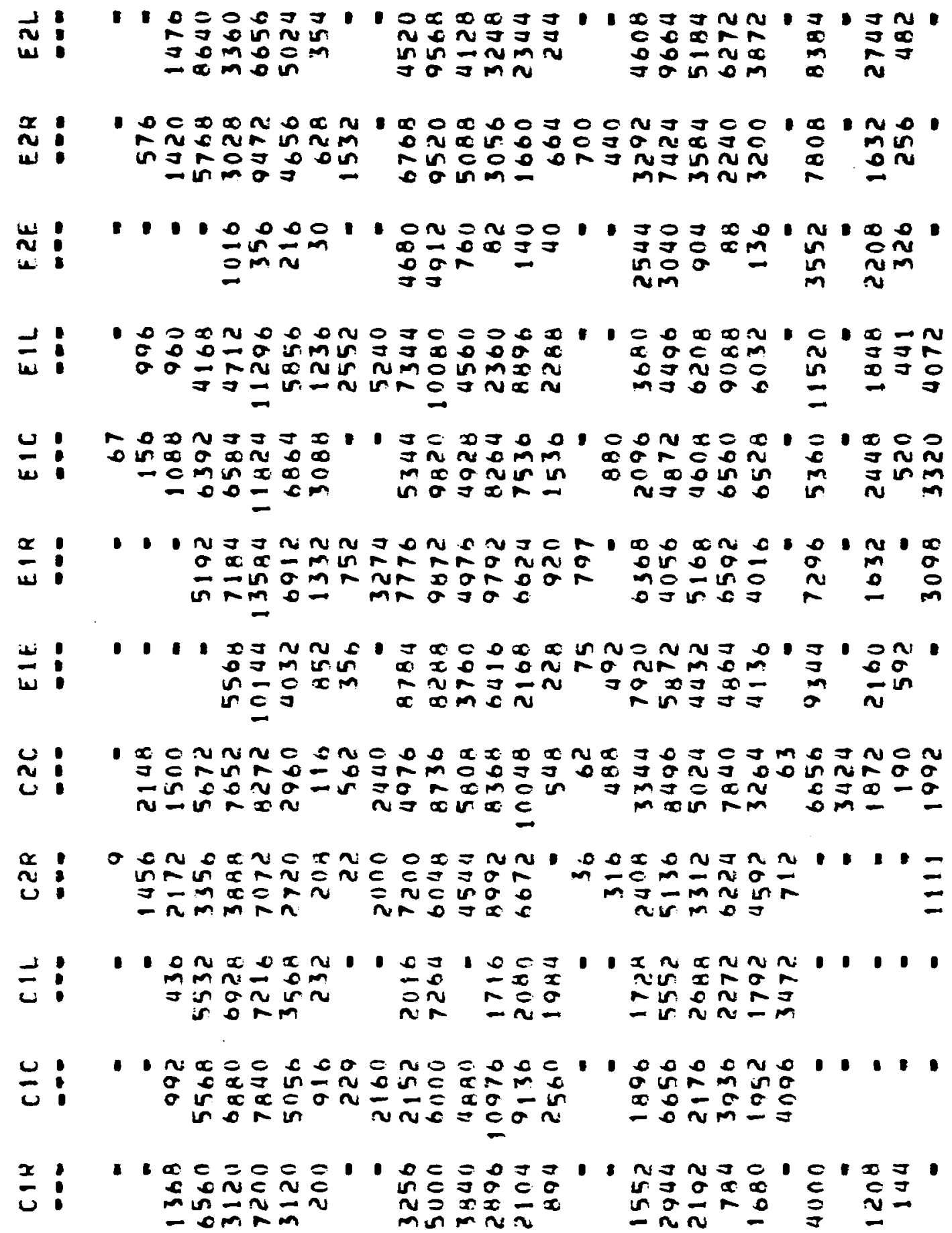

- oc

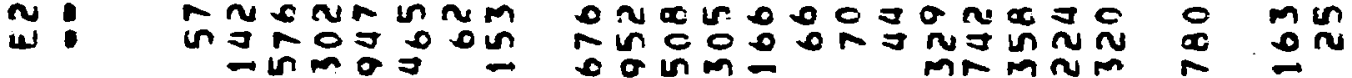

we
n:
$=1$
$=$

- 00000.

on 0 n 000

mp m ru

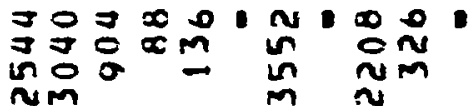

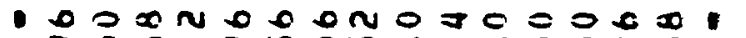

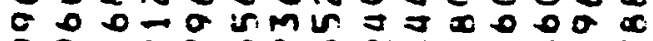

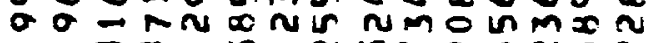

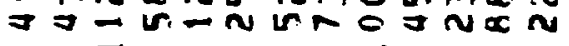

- $000 \Omega+0.0-0$

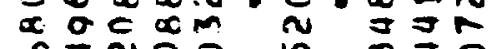
$\rightarrow$ $\rightarrow$ $\rightarrow \geqslant N=0$

$\rightarrow 200$

$\underset{\omega}{\omega}$

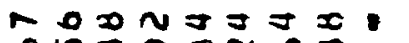

$=2000$

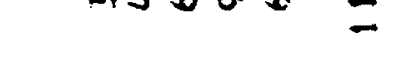

- in 00 an 00

- 0 m in $x<0$

$-0.0=0$

$\Rightarrow$ a 00 a

maroun

in $0 \Rightarrow \infty \mathrm{r}$

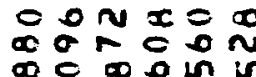

$\infty 6 \infty$ in in

$=000$ $-\infty$

- -

a

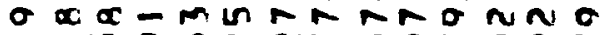

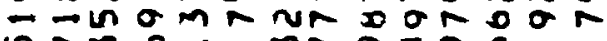

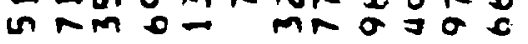

0 in $00 \%$

mo $-\ln 0$

00 in 0

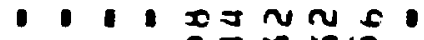
$0 \geqslant m$ in
in 00

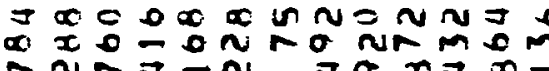

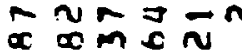

$\rightarrow 0 \pi \geqslant \infty=$

$r n=0=$

$$
\begin{array}{ll}
\nabla & 0 n \\
\cdots & 0 \\
\sigma & m
\end{array}
$$

(:)

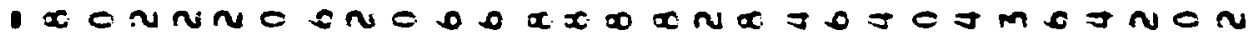

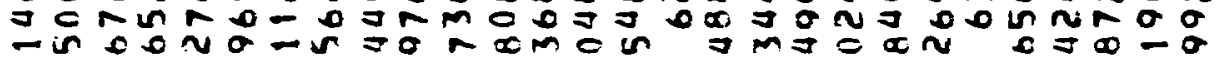

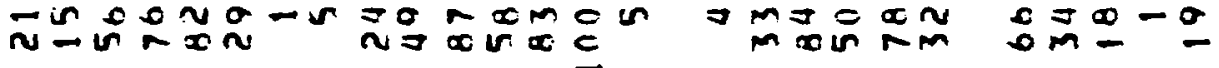

a

(2)

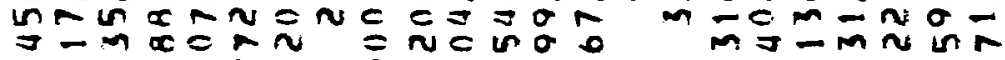

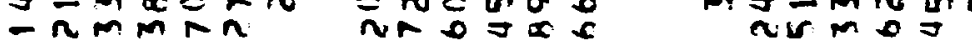

$\underset{10}{1}$

- $0 \operatorname{coc} 0 \times 1$

x $n$ annni

$\underset{\omega}{\omega}:$

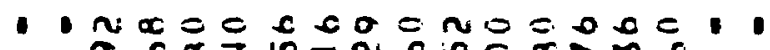

Lin $x \sim c m$

- in $0 N n-m$

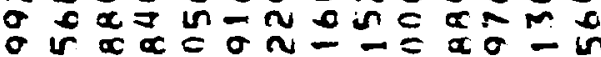

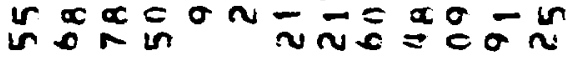

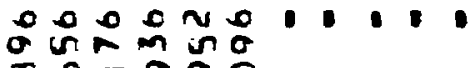

c 0 -

2

- $\infty$

$\infty e=00=1$
añ 0

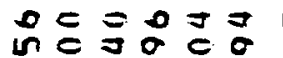

$n \leq x \leq x$

mum $\mathrm{m}$

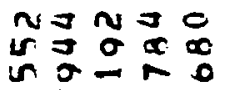

$0 \quad 0 \pm 1$
$0 \quad 0 \pm$

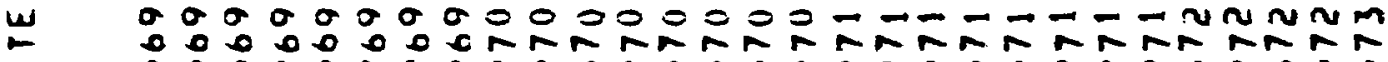

a nir or coc 

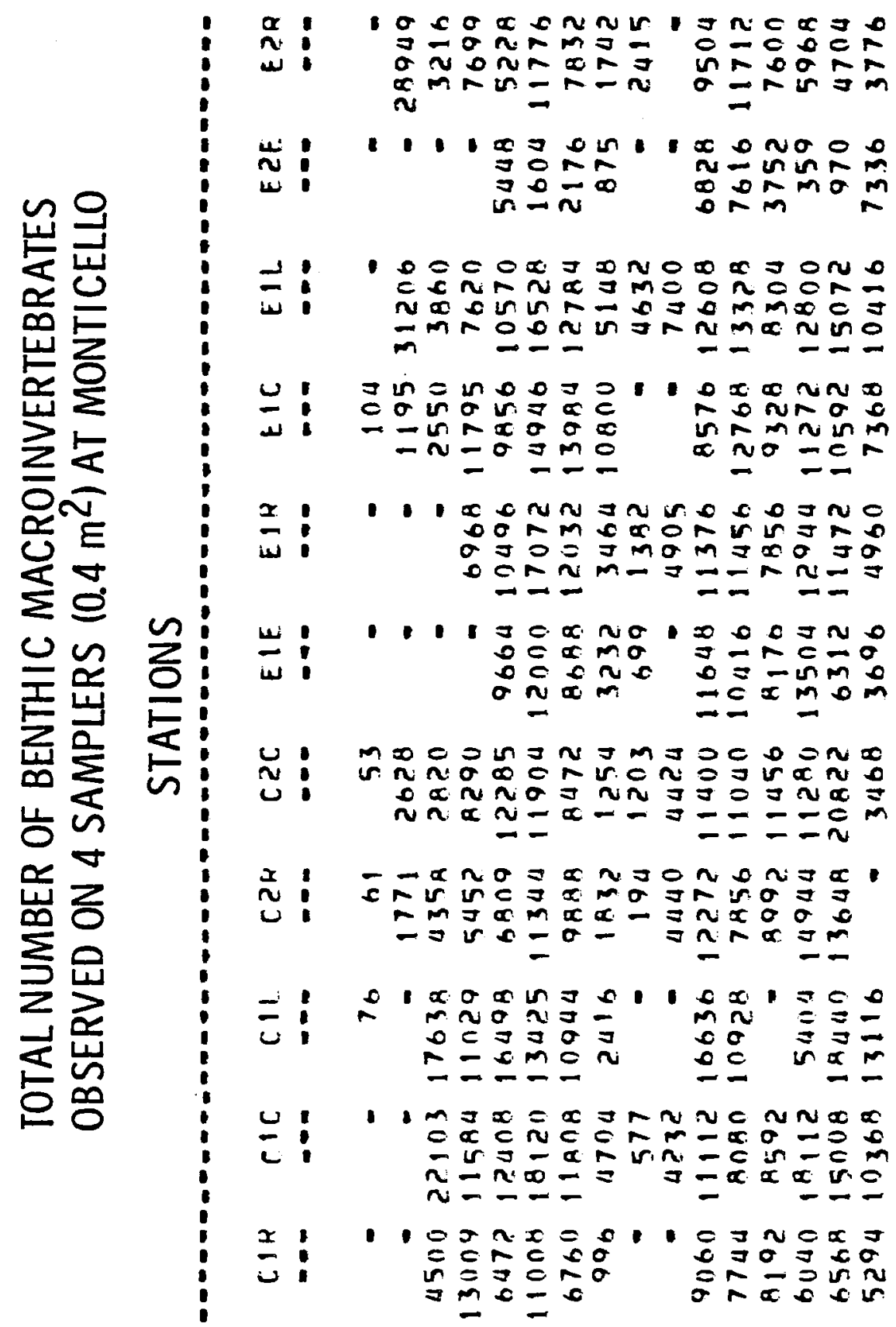

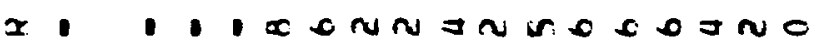

- Dormocoringan

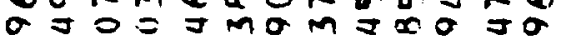
\% $\rightarrow-\infty-\infty$

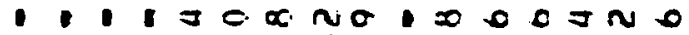

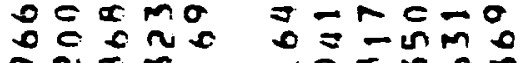
oำ 0 a

U. $m \leq 0=4 J n$ J

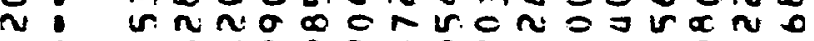

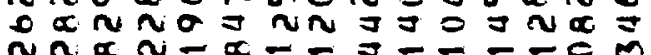

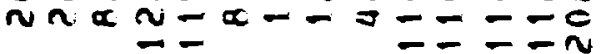

x $-\bar{x}$ -

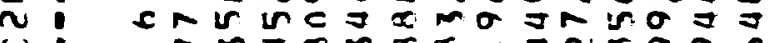
$\sim m J \infty m \alpha-\exists n x \sigma \sigma d$

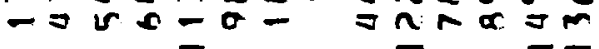

$=:$

- ix 0 in $\pi 01$ $\operatorname{mon} \pi$ $0 \subset \exists=\sigma \quad 7$ co $0=$ IImon $N 0$ Nam

U.,$m \exists x=\infty \nabla m N N C N N \infty x$

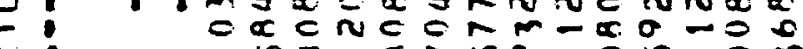
- $r=-\alpha r$ rin-cin-cm

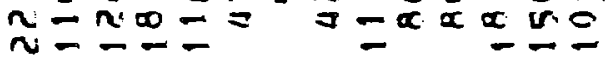

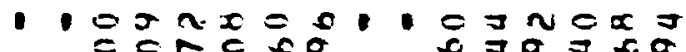

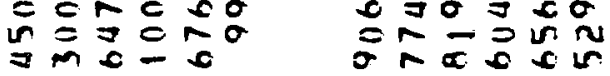

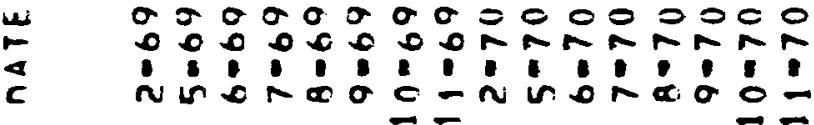




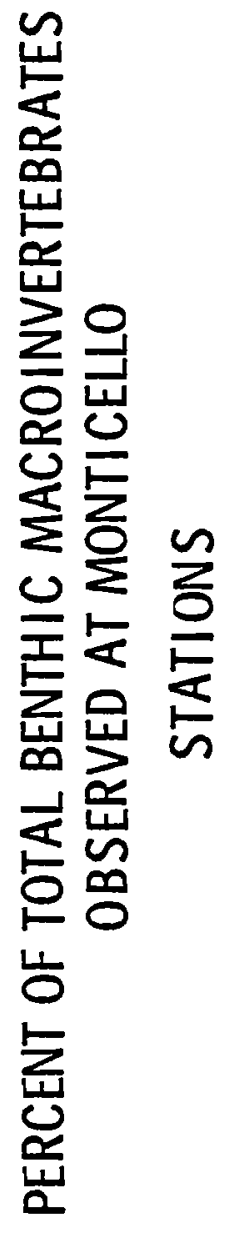

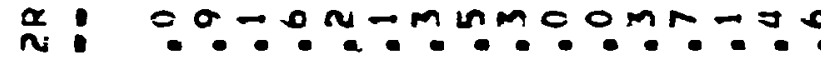

u

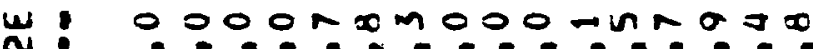

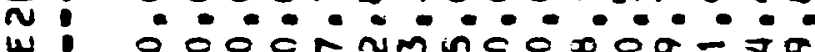

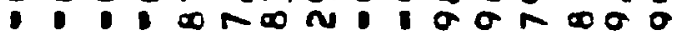

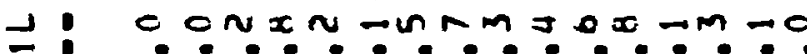
4)

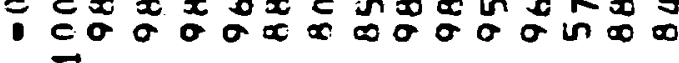

U vind in a cooco-chmo-

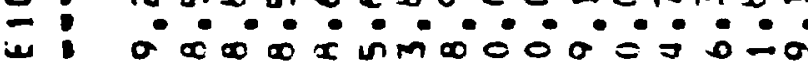

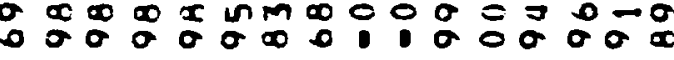

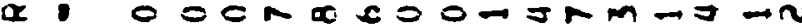

W: $: 00$ icina

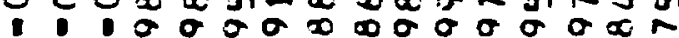

L. $=0000$ nom comomn m

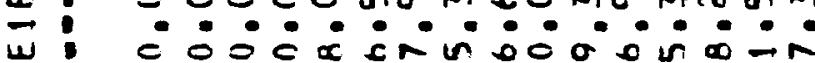

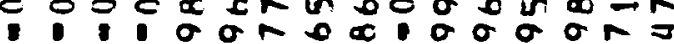

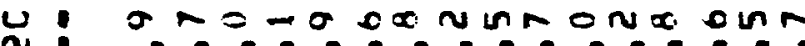
r:

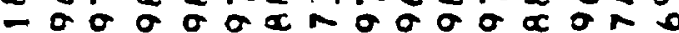

$\alpha:-\alpha=0$ un $\quad-\alpha-m \sim m m o \alpha c$

4. $\div$ in r.

$=000=\neq-m-c c m o=n-c$

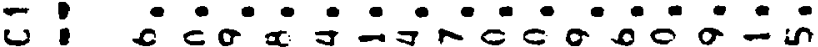

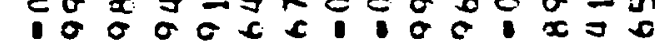

$\omega=0$ : $=0 x-\infty \sigma-0,0 \geqslant m \ln n$ -

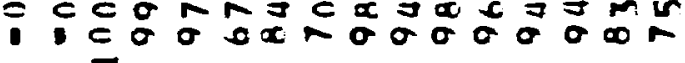

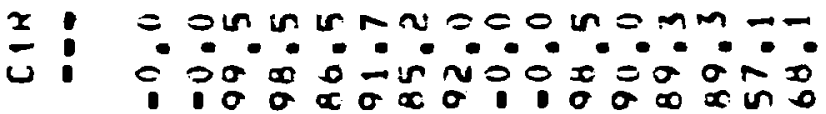

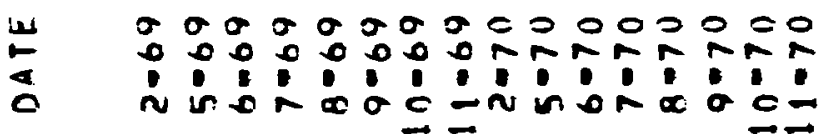


APPENDIX D

BENTHOS STATION RATIOS . 


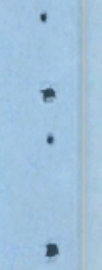




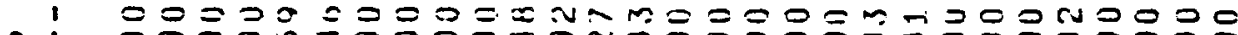
응ำ

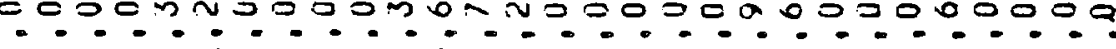

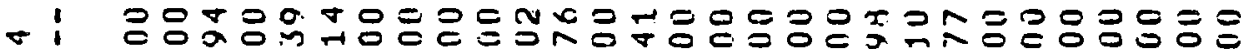

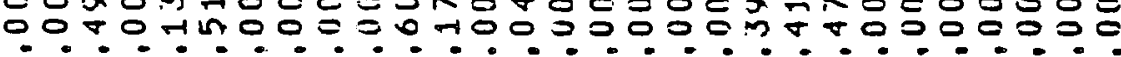
$\ddot{1}$

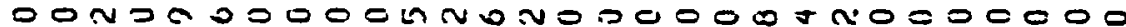

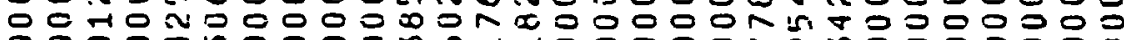

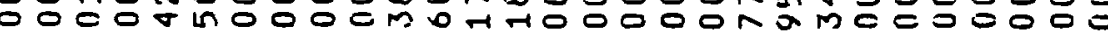

$$
-i
$$$$
:-
$$

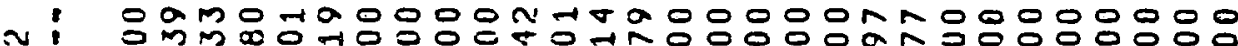

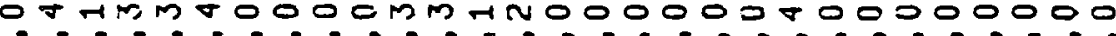
-

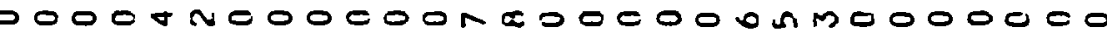

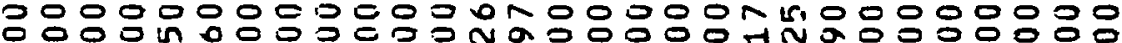
.0.0.0.

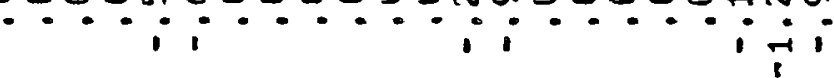

$\underset{⿱ 乛}{\sigma}$

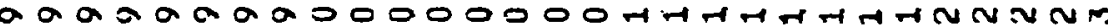

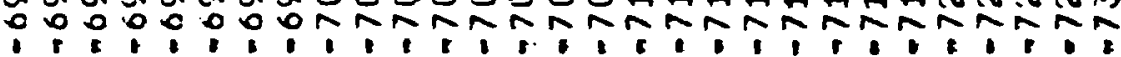

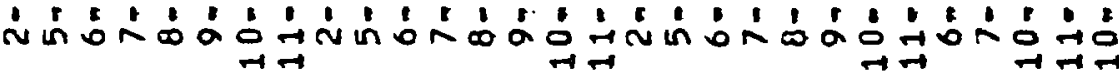

s :

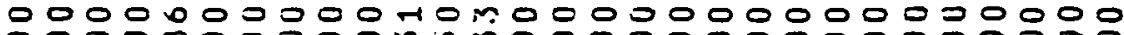

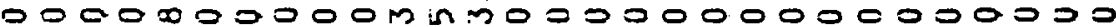

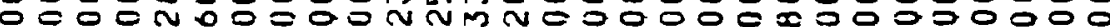
in $\sim$ is. 0 $\infty \nabla$ -

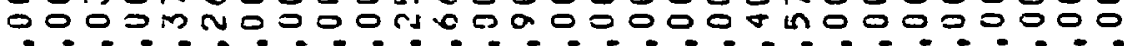
Am in

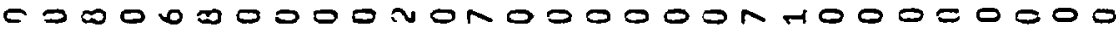

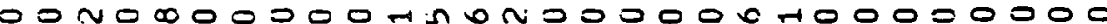

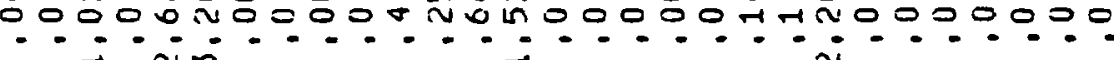

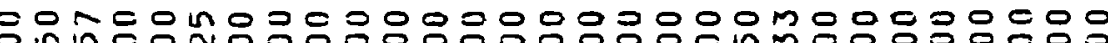

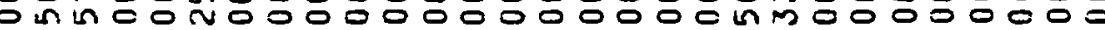

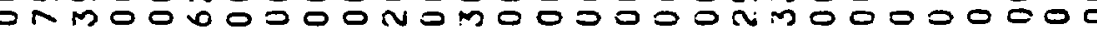
nitivina $\sim$ i

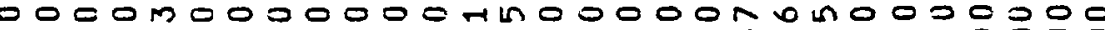

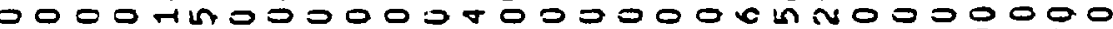
$0000 m N 300000$ m 0000000040000000

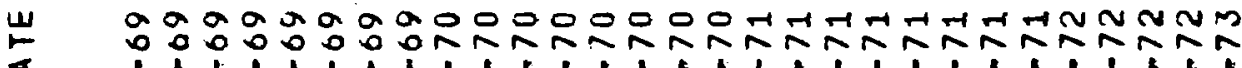
ง $\rightarrow+1$ $+1-1$ 


\section{INTERPRET ING STEM AND LEAF DISPLAYS}

Stem and leaf displays are very much like histograms, but contain additional information. The stem is in some ways analogous to the class mark or midpoint of the usual histogram while the leaf provides the actual values of the numbers contained in the bars of usual histograms. Thus, a stem and leaf such as -1.4 ( 9 found at depth of 1 of the logarithm of the Macronemum ratios display, has an actual value of -1.49 . Similarly at depth 15 (from the positive end) we find +.4 ) 12348 which indicates 5 values are plotted; $0.41,0.42,0.43,0.44$ and 0.48 , respectively. The column labelled depth (which we used above) is simply a convenient way to "count in" from either end to the median value (shown as $M$ under the column labelled scrawl) of the distribution. The symbols $\mathrm{H}$ are the quartile points and the astrisks $(*)$ denote the ends of the distribution. Note at depth 19 (actually the first 19 numbers) of the arithmetic display of Macronemum ratios that both the extreme and quartile values occur in the same "bar". 


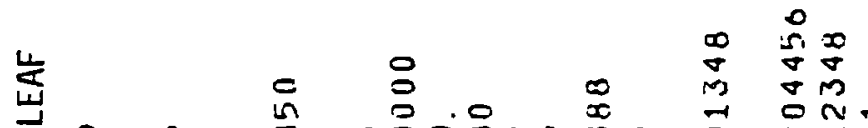

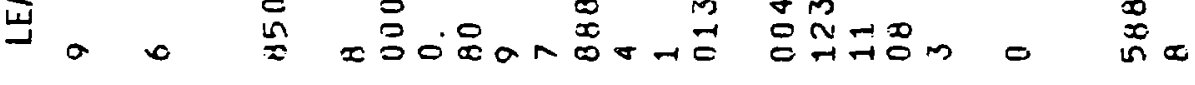

I

$I$

$\Sigma \quad I$

$\star$

吉

$\stackrel{2}{2}$

$\underset{\sigma}{\ln }$

$\frac{1}{2}$

$\approx \infty$

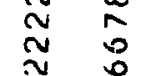

in in

$\rightarrow \underset{2}{2} \approx$

In

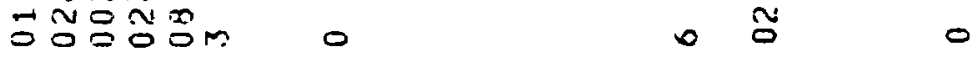

岩 


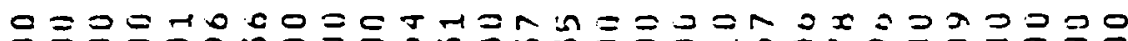

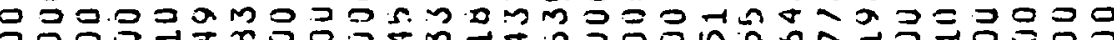

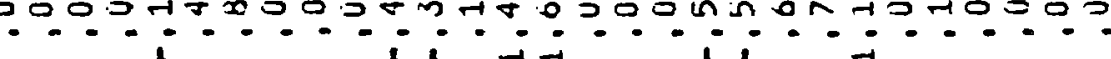

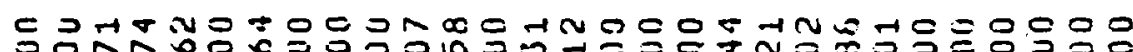

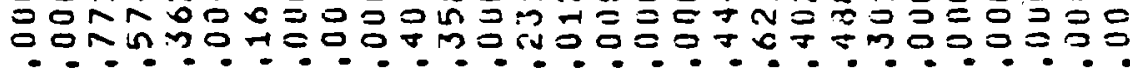
- 0 i

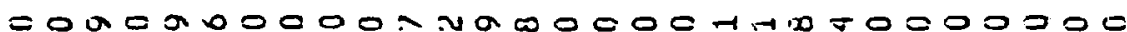

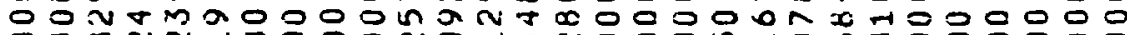

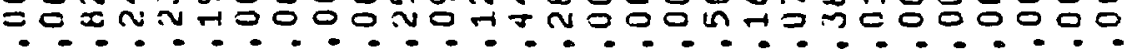

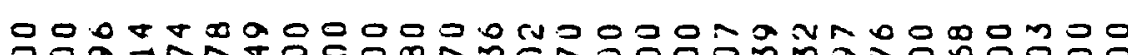

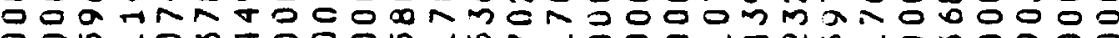
ogingmJo0

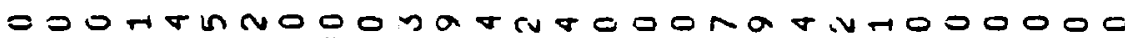

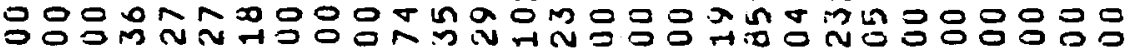

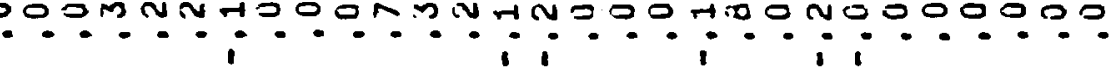

$\stackrel{w}{2}$

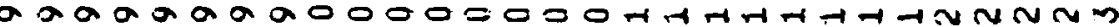

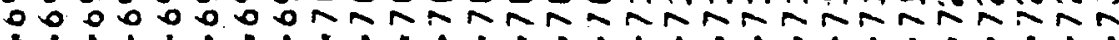

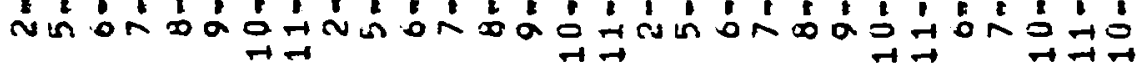

嵌

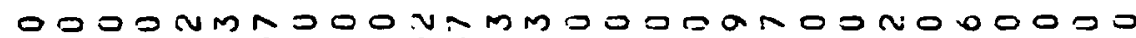

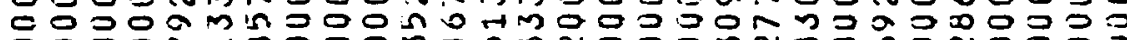

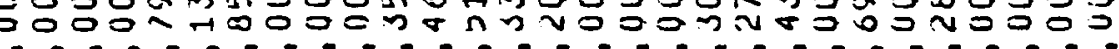
in $\rightarrow \sim m$ in in $-i$

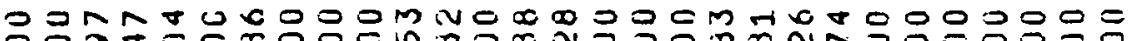
o 0 amo

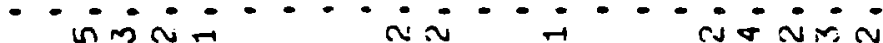

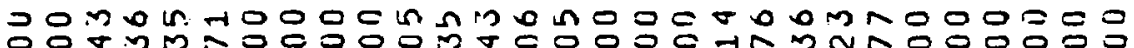

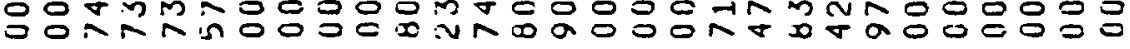

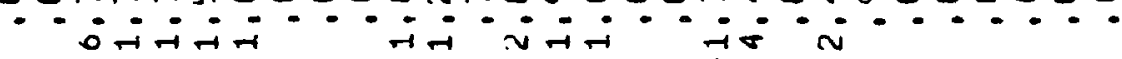

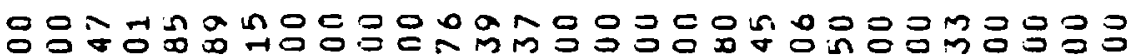

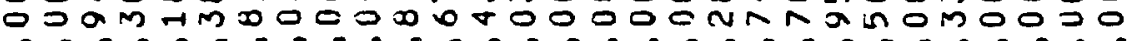

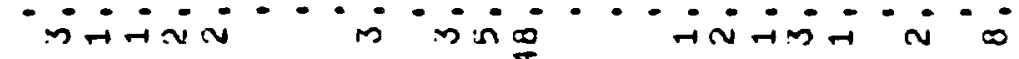

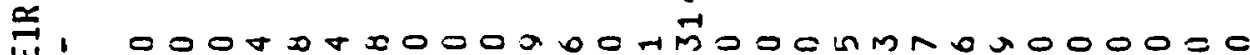
世! $\underset{1}{\infty}$

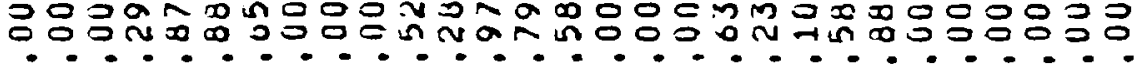
$\dot{v} \dot{4}-\dot{0}$ $\ln i$ $n-1$

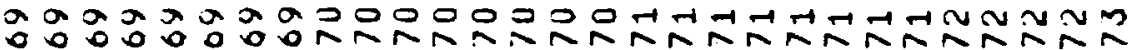

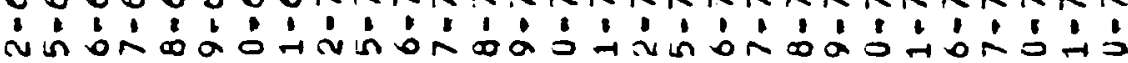
국에 


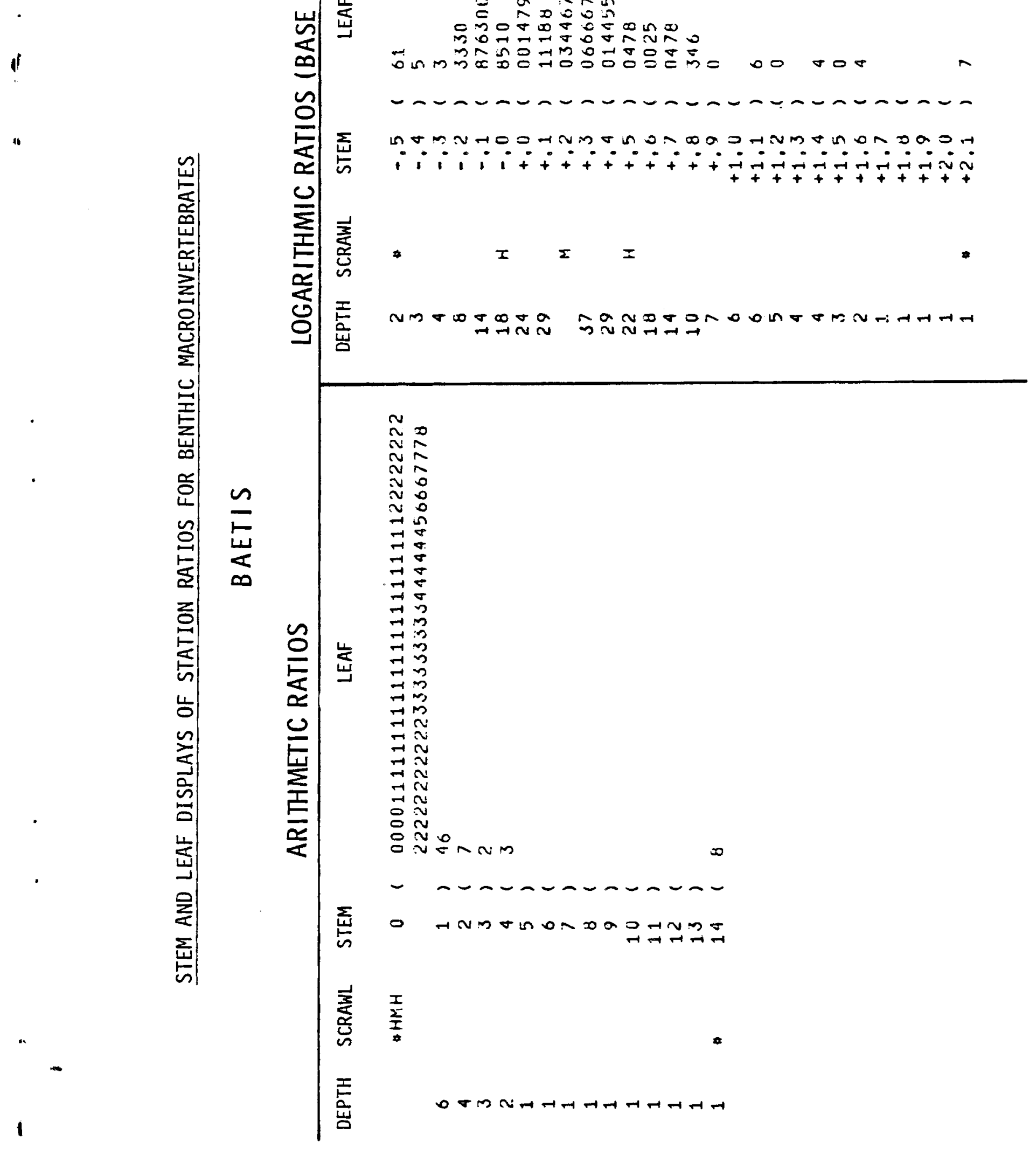




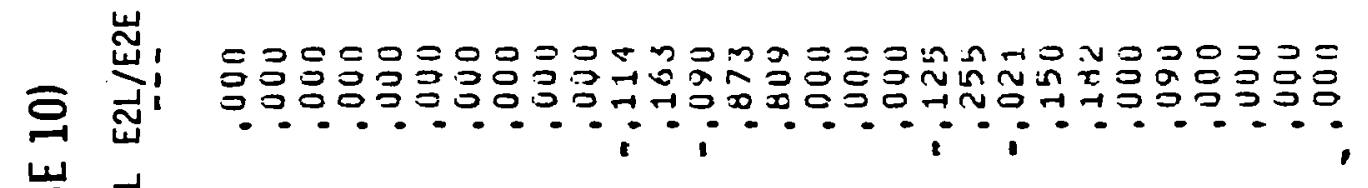

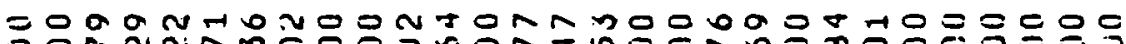

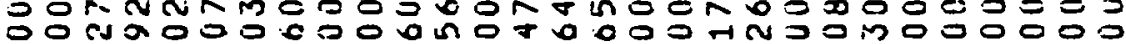
o.

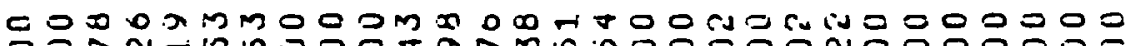

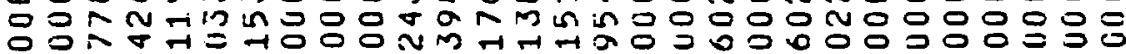

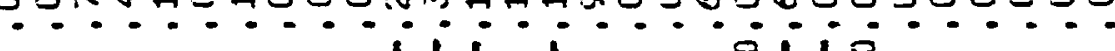

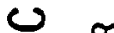
$\underset{\sim}{\sim}$

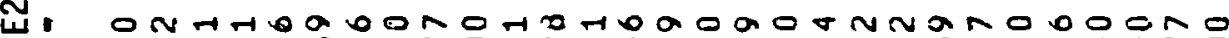

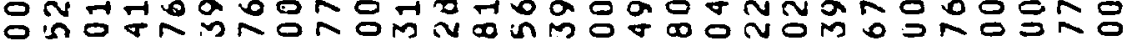
ommo 孚:

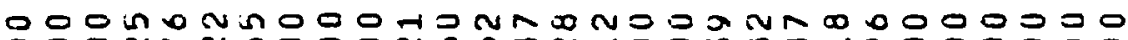

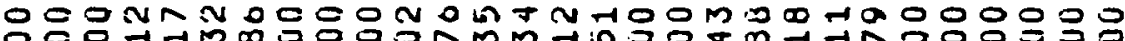
o.

$\frac{w}{0}$

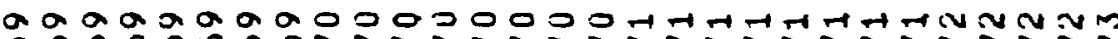
o d o d o o o o 心 $\rightarrow+$ $\rightarrow+$

o000000000\%

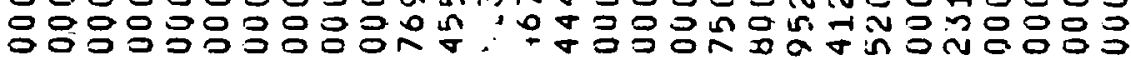

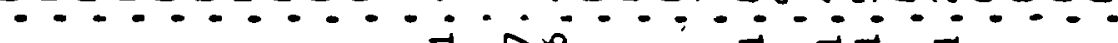

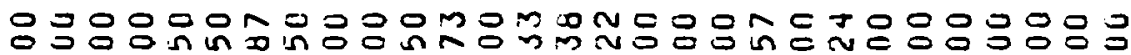

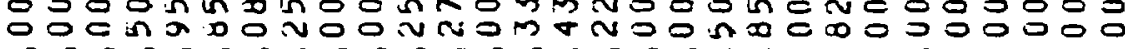

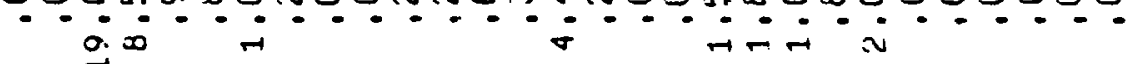

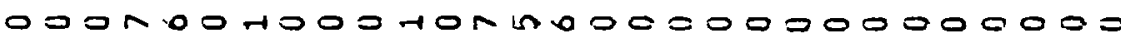

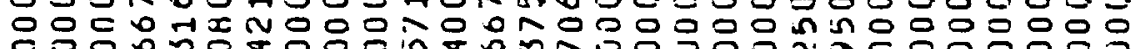

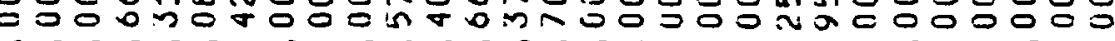

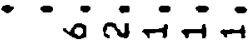
$\dot{-i} \cdot \dot{-i}$

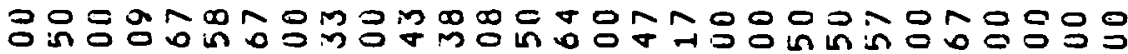

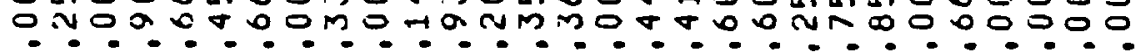
is iv iv i

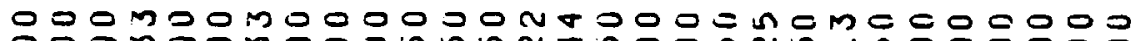

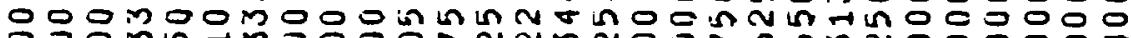

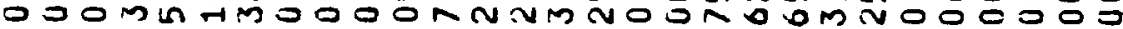

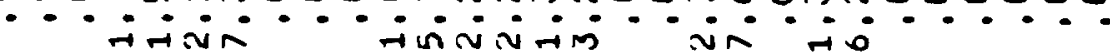


STEM AND LEAF DISPLAYS OF STATION RATIOS FOR BENTHIC MACROINVERTEBRATES

\section{STENONEMA}

ARITHMETIC RATIOS

LOGARITHMIC RATIOS (BASE 10)

\begin{tabular}{|c|c|c|c|c|c|c|c|c|c|}
\hline \multicolumn{2}{|c|}{ DEPTH | SCRAWL } & \multicolumn{2}{|c|}{ STEM } & LEAF & \multirow{3}{*}{$\begin{array}{c}\text { DEPTH } \\
\qquad \begin{array}{c}6 \\
7\end{array}\end{array}$} & \multirow{2}{*}{$\begin{array}{l}\text { SCRAWL } \\
\end{array}$} & \multirow{3}{*}{$\begin{array}{l}\text { STEM } \\
\begin{array}{r} \\
-.6\end{array}\end{array}$} & \multirow[b]{2}{*}{1} & \multirow{2}{*}{$\begin{array}{r}\text { LEAF } \\
850000\end{array}$} \\
\hline 31 & $\Delta \mathrm{H}$ & 0 & 1 & 2722223334444456667777788808994 & & & & & \\
\hline & M & 1 & ) & 000000011233334445555689 & & & & ) & 6 \\
\hline 24 & H & 2 & i & 0011222788 & 12 & & -.4 & 1 & 88640 \\
\hline 14 & & 3 & ) & 02 & 15 & & -.3 & ) & 854 \\
\hline 12 & & 4 & 1 & 04 & 17 & & -.2 & 1 & 42 \\
\hline 10 & & 5 & 1 & 8 & 25 & H & -.1 & ) & 98888521 \\
\hline 9 & & 6 & 1 & 024 & 35 & &,- 0 & 1 & 9877432220 \\
\hline 6 & & 7 & ) & 356 & & M & +.0 & 1 & 002349 \\
\hline 3 & & 8 & 1 & 5 & 38 & & +.1 & 1 & 22234556888 \\
\hline 2 & & 9 & ) & 0 & 27 & & +.2 & ) & 067 \\
\hline 1 & & 10 & 1 & & 24 & $H$ & +.3 & 1 & 0023555 \\
\hline 1 & & 11 & 1 & & 17 & & +.4 & ) & 3448 \\
\hline 1 & & 12 & 1 & & 13 & & +.5 & 1 & 1 \\
\hline 1 & & 13 & 1 & & 12 & & +.6 & 1 & 05 \\
\hline 1 & & 14 & 6 & & 10 & & +.7 & 1 & OB \\
\hline 1 & & 15 & 1 & & $\theta$ & & +.8 & 1 & 01778 \\
\hline 1 & & 16 & ( & & 3 & & +.9 & 1 & 35 \\
\hline 1 & & 17 & ) & & 1 & & +1.0 & ) & \\
\hline 1 & & 18 & 1 & & 1 & & +1.1 & ( & \\
\hline 1 & 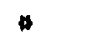 & 19 & 1 & 0 & 1 & - & +1.2 & 1 & 8 \\
\hline
\end{tabular}




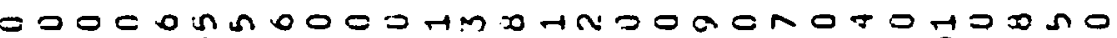

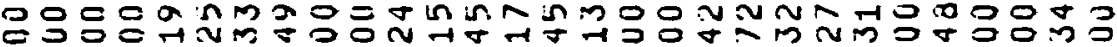
1

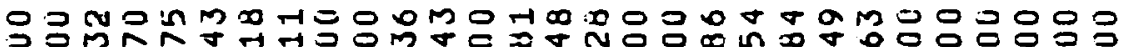
0 O o.

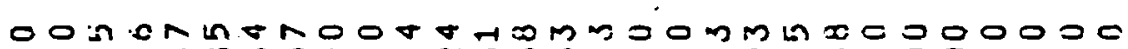

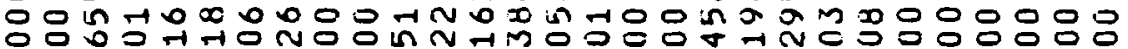

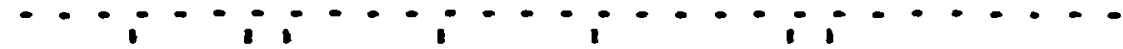

00

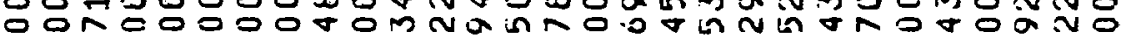

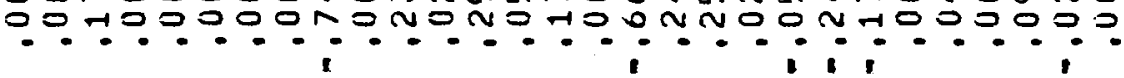

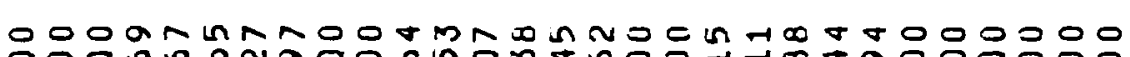

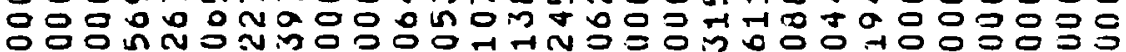
-... - :

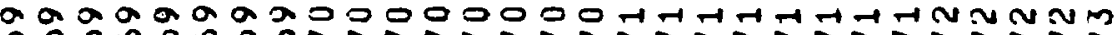

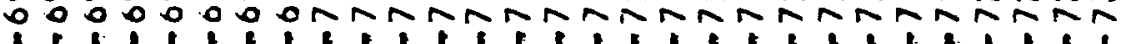
ง่อง नोन

峲

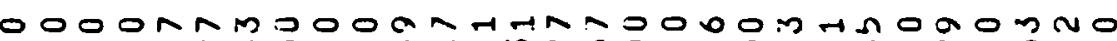

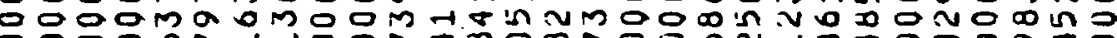

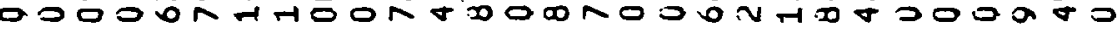

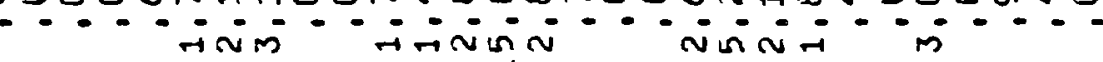

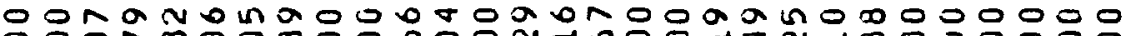

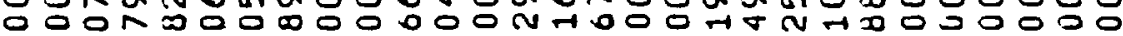

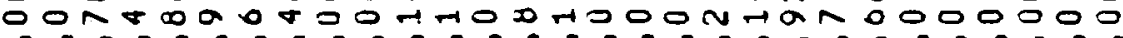

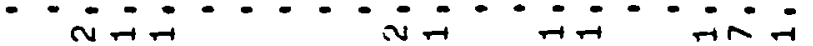

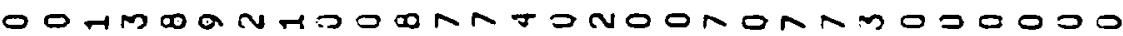

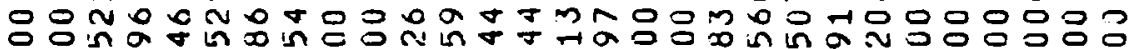

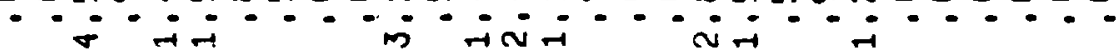

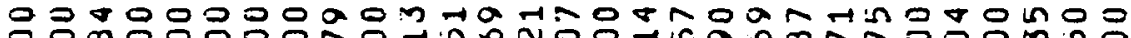
o. ?.?.0.0.0.? $\stackrel{ }{ }$

W.

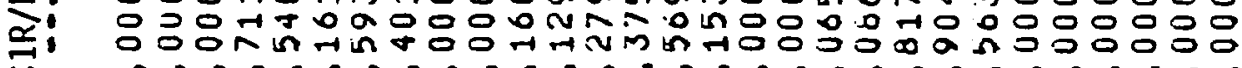

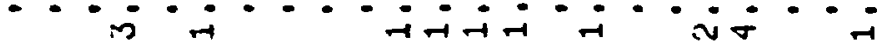

$\underset{⿱ ㇒}{\rightleftarrows}$

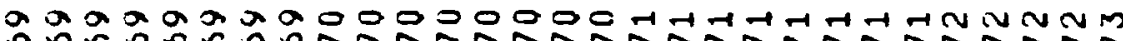

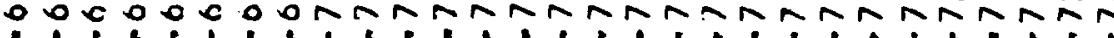
ڤ $\rightarrow \rightarrow$ $\rightarrow-1$

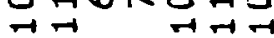


STEM AND LEAF DISPLAYS OF STATION RATIOS FOR BENTHIC MACROINVERTEBRATES

\section{CHIRONOMINI}

ARITHMETIC RATIOS

\begin{tabular}{|c|c|c|c|c|c|c|c|c|c|}
\hline DEPTH & SCRAWL & STEM & & LEAF & DEPTH & SCRAWL & STEM & & LEAF \\
\hline $\begin{array}{r}20 \\
9 \\
5 \\
3 \\
2 \\
2 \\
1 \\
1 \\
1 \\
1 \\
1 \\
1 \\
1 \\
1\end{array}$ & $\begin{array}{l}\because H \\
M H\end{array}$ & $\begin{array}{r}0 \\
1 \\
2 \\
3 \\
4 \\
5 \\
6 \\
7 \\
8 \\
9 \\
10 \\
11 \\
12 \\
13 \\
14 \\
15\end{array}$ & $\begin{array}{l}\text { ( } \\
\text { f } \\
\text { ) } \\
\text { ( } \\
\text { ( } \\
\text { ) } \\
\text { ( } \\
\text { ) } \\
\text { f }\end{array}$ & $\begin{array}{l}22455555566666677778899999 \\
00001111111112222223444555 \\
556677838999 \\
01122477888 \\
0137 \\
15 \\
2 \\
1\end{array}$ & $\begin{array}{r}1 \\
2 \\
2 \\
3 \\
7 \\
15 \\
19 \\
30 \\
39 \\
28 \\
19 \\
14 \\
8 \\
5 \\
3 \\
2 \\
1 \\
1 \\
1\end{array}$ & $\begin{array}{l}H \\
M \\
H\end{array}$ & $\begin{array}{r}-.7 \\
-.6 \\
-.5 \\
-.4 \\
-.3 \\
-.2 \\
-.1 \\
-.0 \\
+.0 \\
+.1 \\
+.2 \\
+.3 \\
+.4 \\
+.5 \\
+.6 \\
+.7 \\
+.8 \\
+.9 \\
+1.0 \\
+1.1\end{array}$ & $\begin{array}{l}1 \\
1 \\
1 \\
1 \\
1 \\
1 \\
1 \\
1 \\
1 \\
1 \\
1 \\
1 \\
1 \\
1 \\
1 \\
1 \\
1 \\
1 \\
1 \\
1\end{array}$ & $\begin{array}{l}5 \\
7 \\
0 \\
5110 \\
77543220 \\
7653 \\
98654442.211 \\
233445555660899 \\
14567778899 \\
344557789 \\
13449 \\
335558 \\
017 \\
16 \\
2 \\
5 \\
8\end{array}$ \\
\hline
\end{tabular}




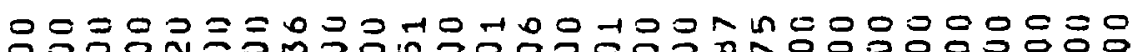

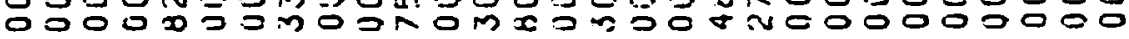
-

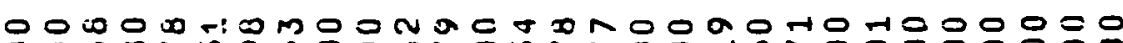

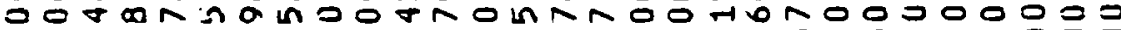

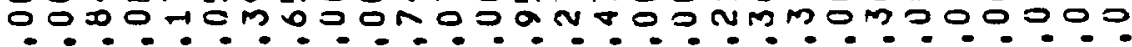

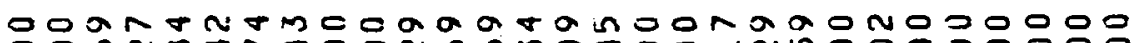

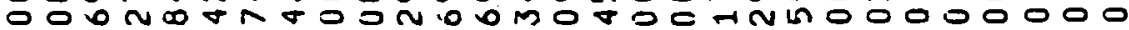

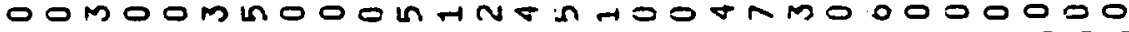

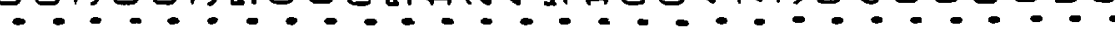

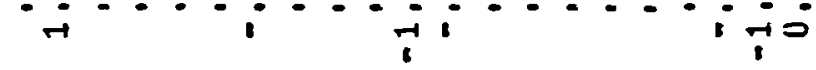

$0 O M O M=N R 000000000 M M M M 00000000$

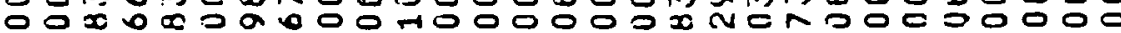

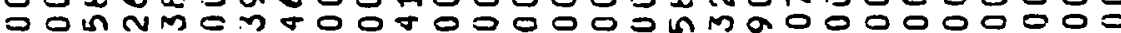

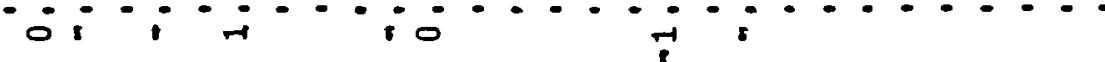

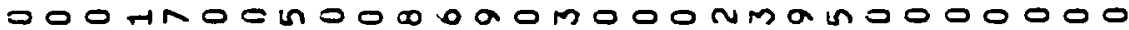
o. 0 o ogommodmo

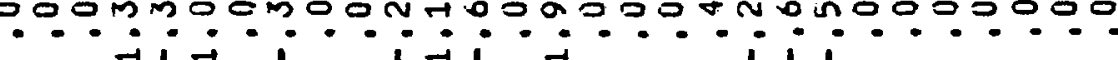
- $-i$ i i i - i i i

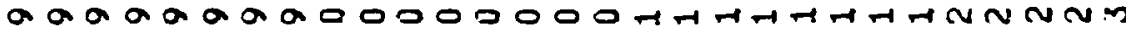

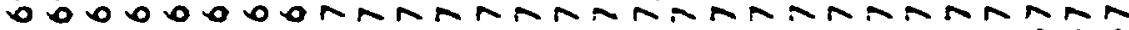
1.11 .1 .1 .121 .11 .11 .121 .11 는

0000000 000 No=00000nNo00000000

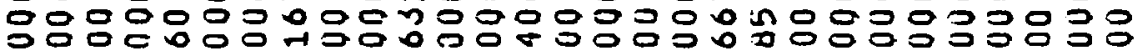

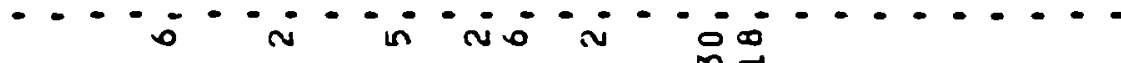

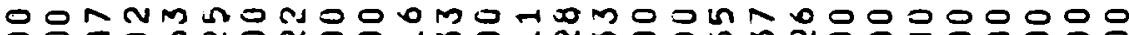

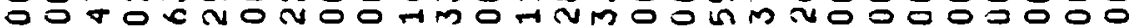

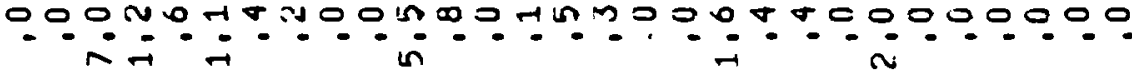

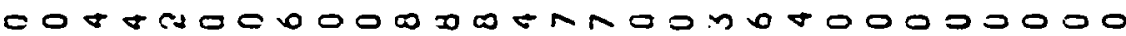

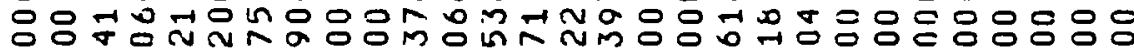

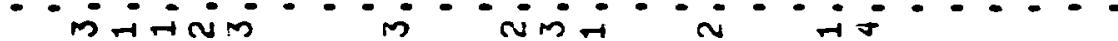
$\sim$

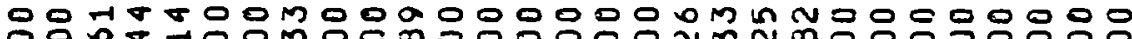

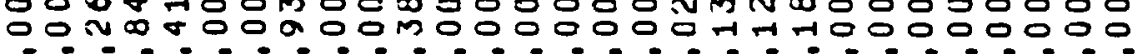
i

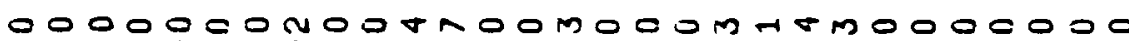

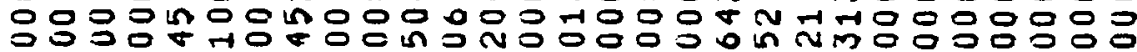

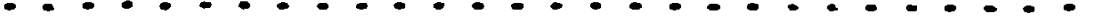
$\stackrel{\circ}{\sim}$

$\omega$
$\square$

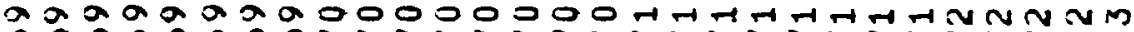
: :

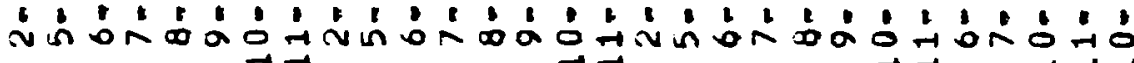
$\rightarrow-1$ $\rightarrow+$

$+\pi$ 


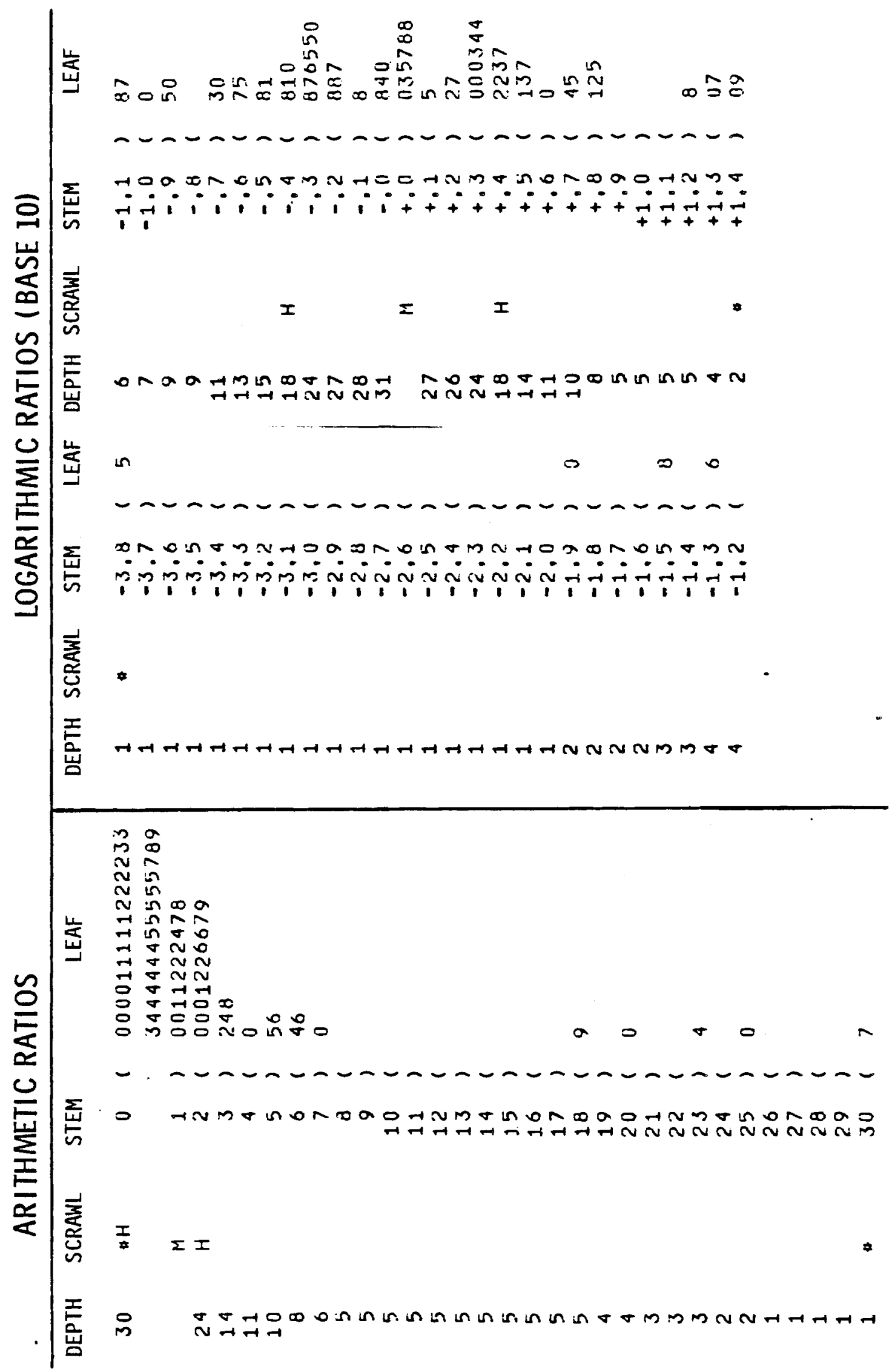




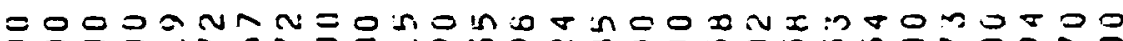

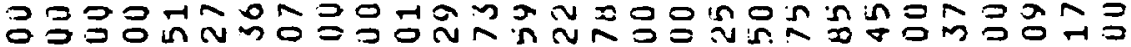

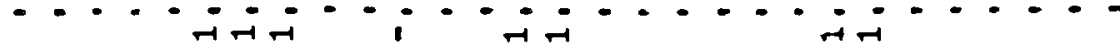

oOmmn

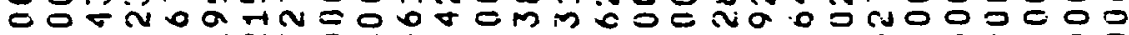

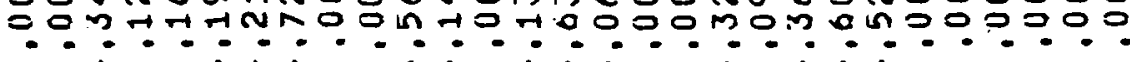

인

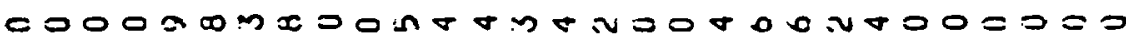

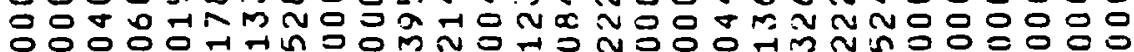

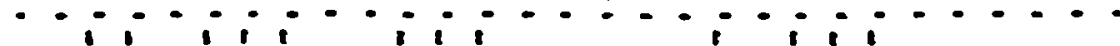

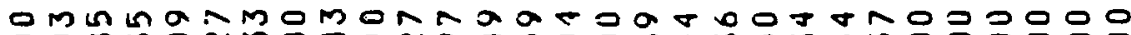

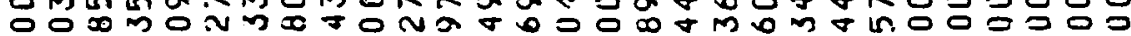

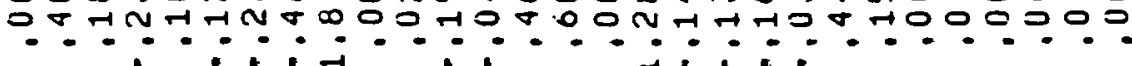

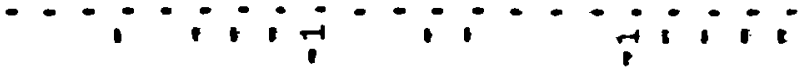

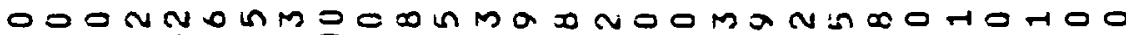

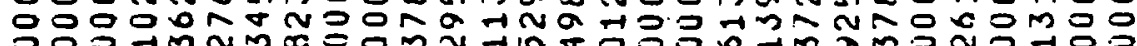

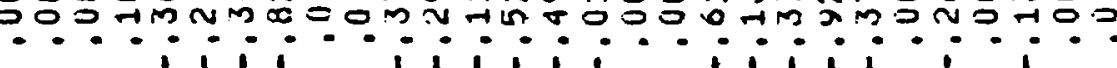

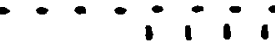

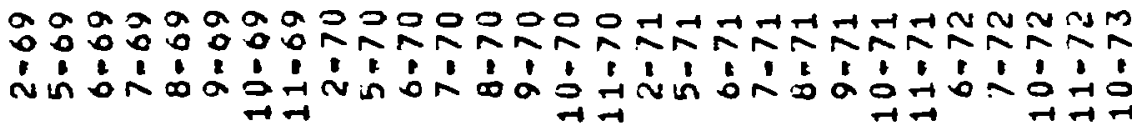

$\underset{0}{\infty}$

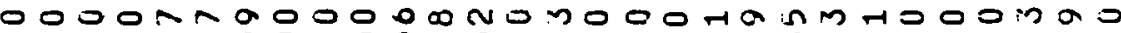

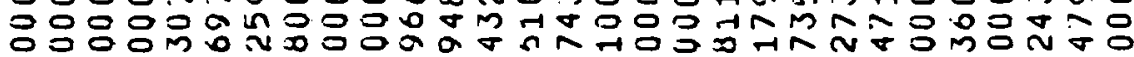

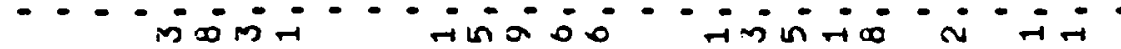
$\rightarrow \infty-1$ $M \rightarrow$

$\sim N$

oorkogamoon 0

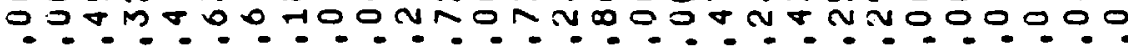
$\rightarrow-1$

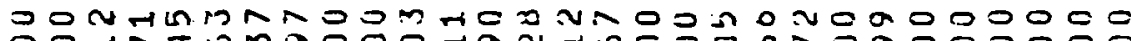

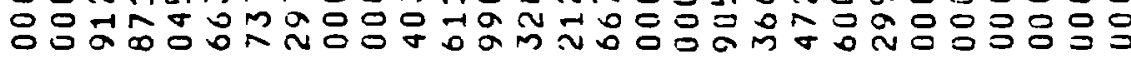

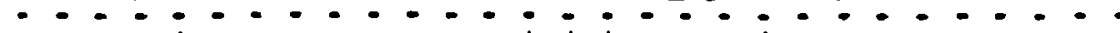
I 2 N $<\frac{\pi}{\mathcal{N}}$

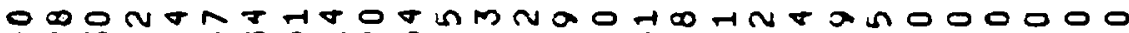

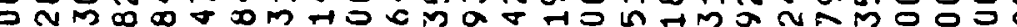

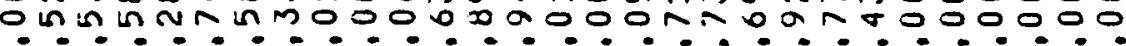

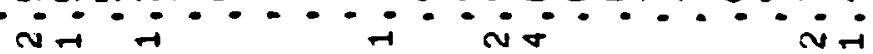

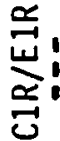

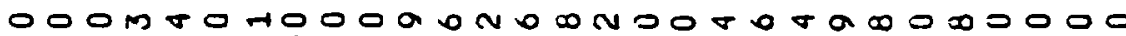

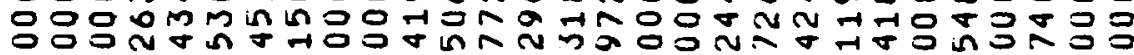
-.............................. $\underset{0}{\infty}$

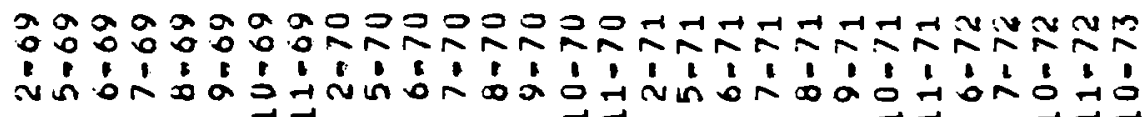




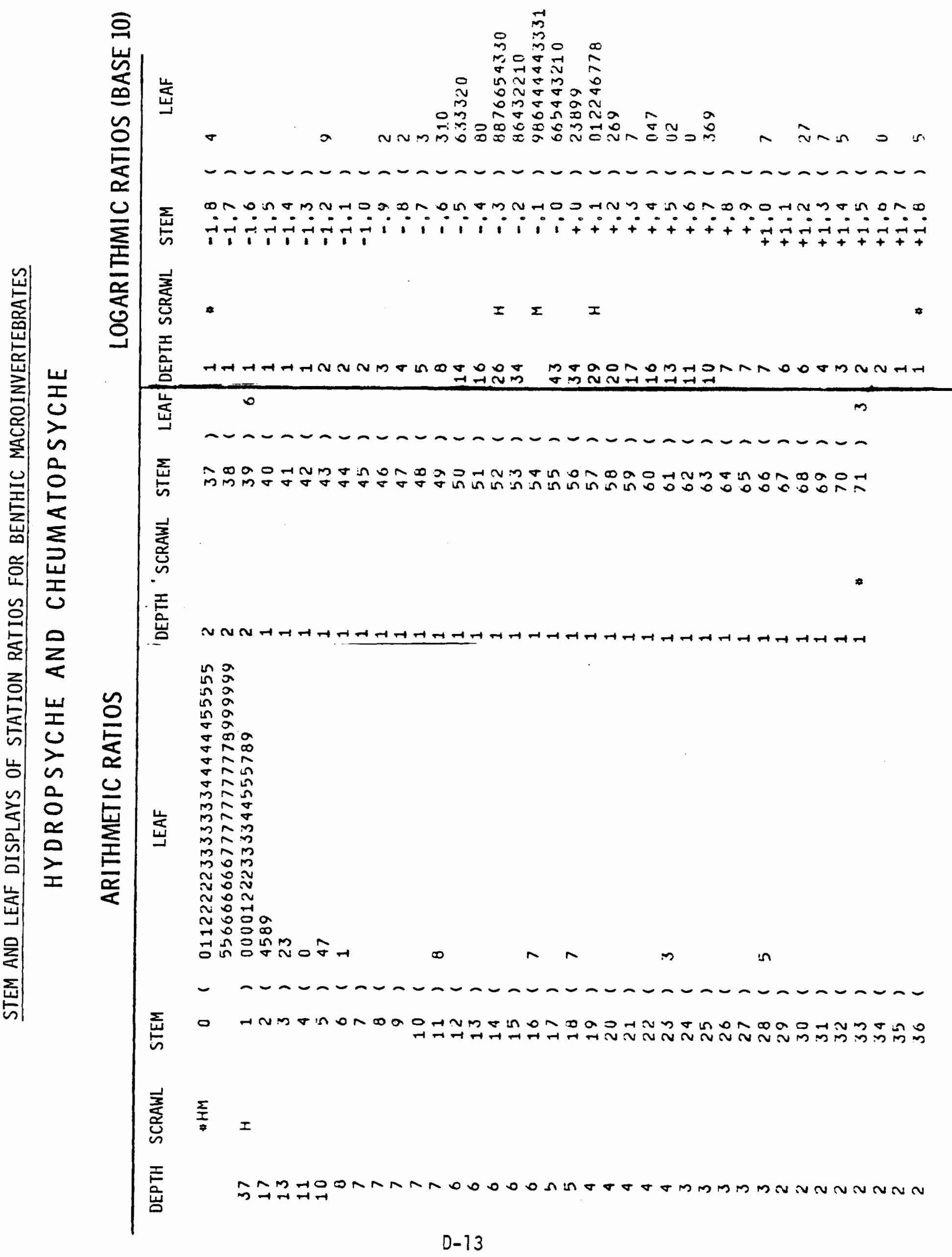




\section{APPENDIX E}

ORIGINAL PERIPHYTON DATA 

TOTAL NUMBERS (ce $11 \mathrm{~s} / \mathrm{cm}^{2}$ ) OF PERIPHYTIC ALGAE OBSERVED AT MONTICELLO

STATIONS

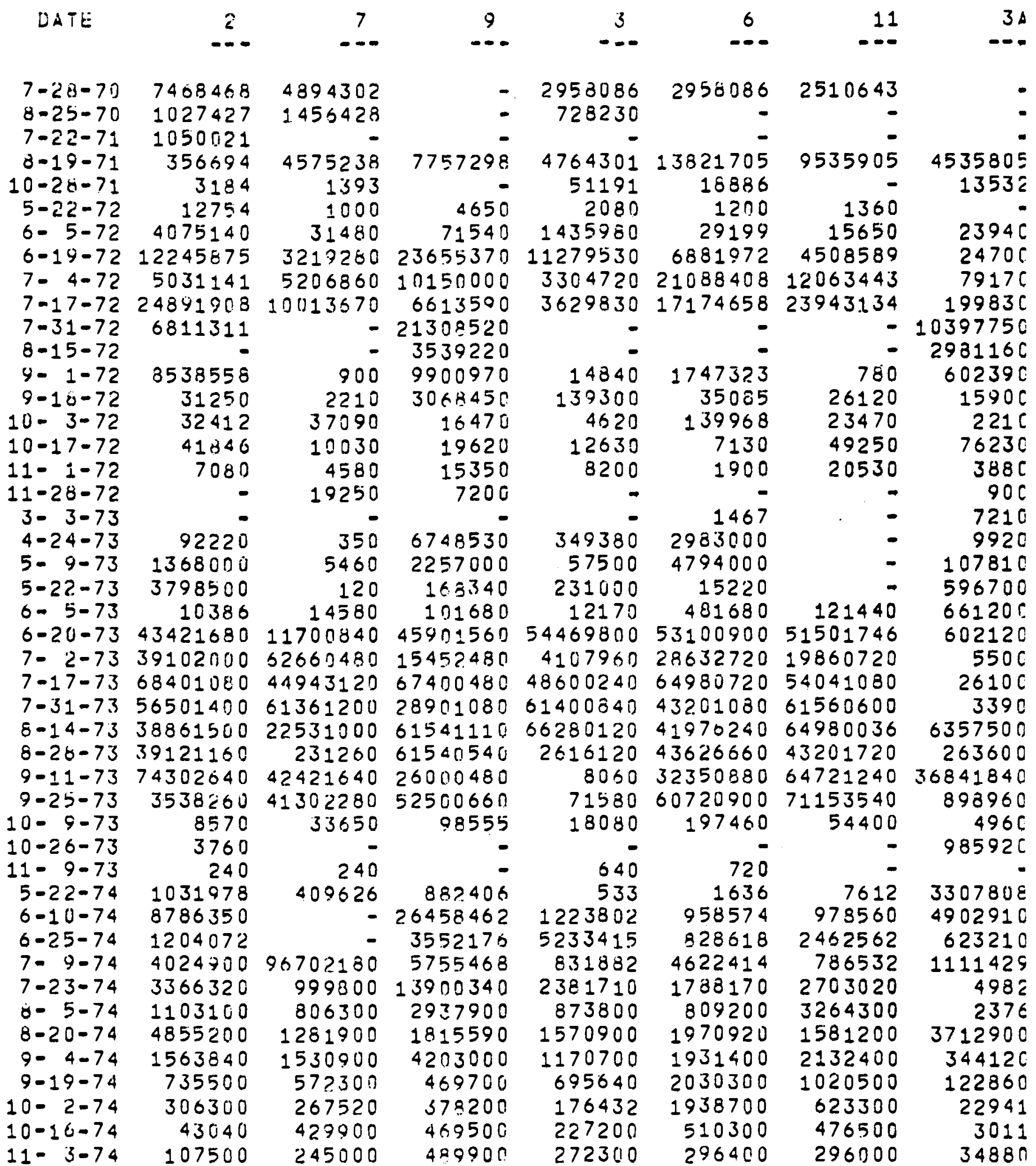


TOTAL NUMBERS (cel1s/ $/ \mathrm{cm}^{2}$ ) OF THE PERIPHYTIC ALGA

Gomphnama ol ivacuim OBSERVED AT MONTICELLO

STATIONS

\begin{tabular}{|c|c|c|c|c|c|c|c|}
\hline DATE & $\begin{array}{c}2 \\
-\infty-\infty\end{array}$ & $\begin{array}{c}7 \\
-00\end{array}$ & 9 & $\begin{array}{c}3 \\
-00\end{array}$ & $\begin{array}{c}6 \\
-\infty\end{array}$ & $\begin{array}{r}11 \\
-0-\end{array}$ & $\begin{array}{r}3 A \\
--0\end{array}$ \\
\hline $\begin{array}{l}5=22-72 \\
6=5-72 \\
0-19-72 \\
7-4-72 \\
7-17-72 \\
9-1-72 \\
9=18-72 \\
10-3-72 \\
10-17-72 \\
11=1-72 \\
11-28-72 \\
2-16-73 \\
3-3-73 \\
4-24-73 \\
5-22-73 \\
6-5-73 \\
6-20-73 \\
7=2-73 \\
9-25-73 \\
10-9-73 \\
11-9-73 \\
5-22-74 \\
6-10-74 \\
6-25-74 \\
7-9-74 \\
7-23-74 \\
8-5-74 \\
8-20-74 \\
9-4-71 \\
9-19-74 \\
10-2-74 \\
10-16-74 \\
11-3-74\end{array}$ & 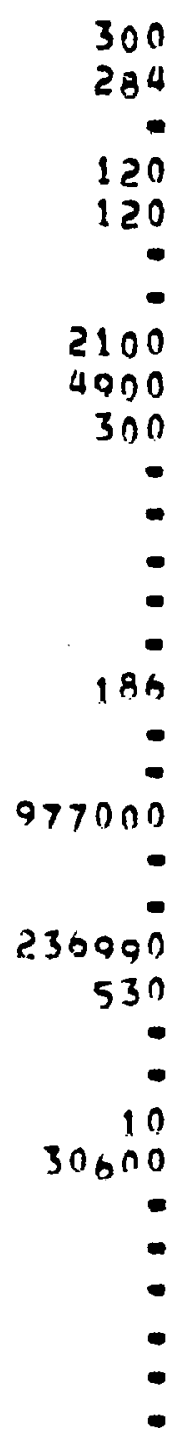 & 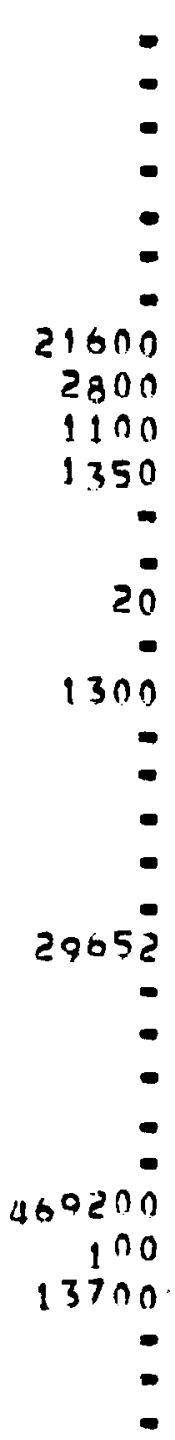 & 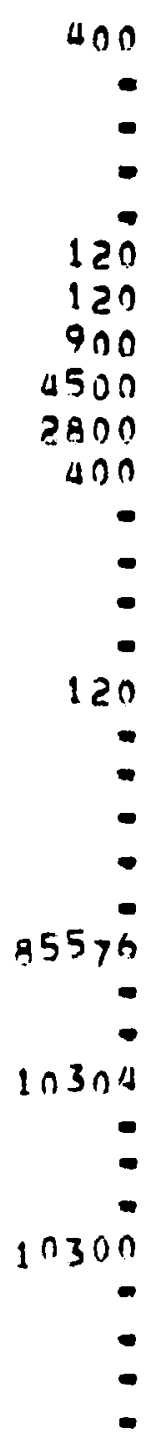 & 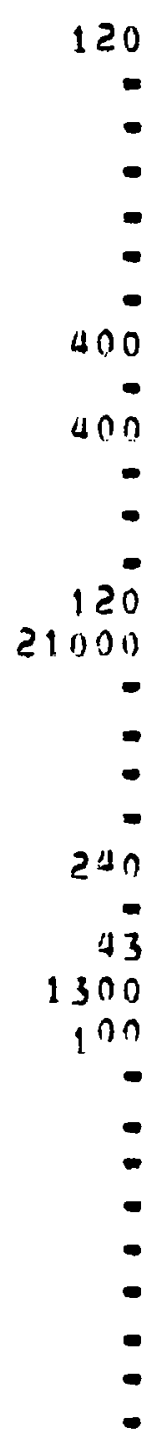 & 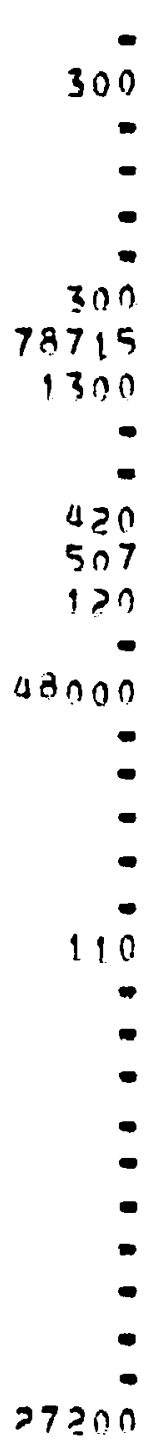 & 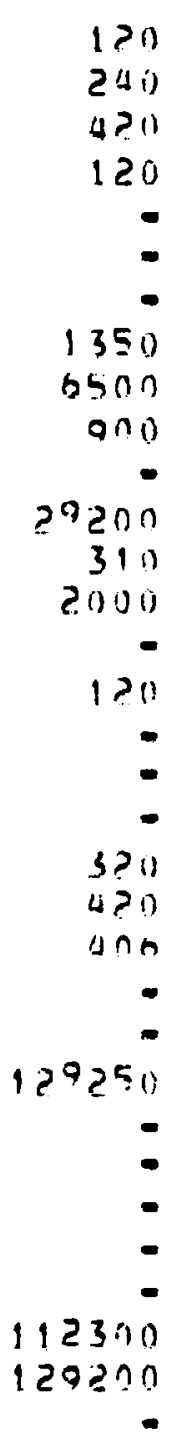 & 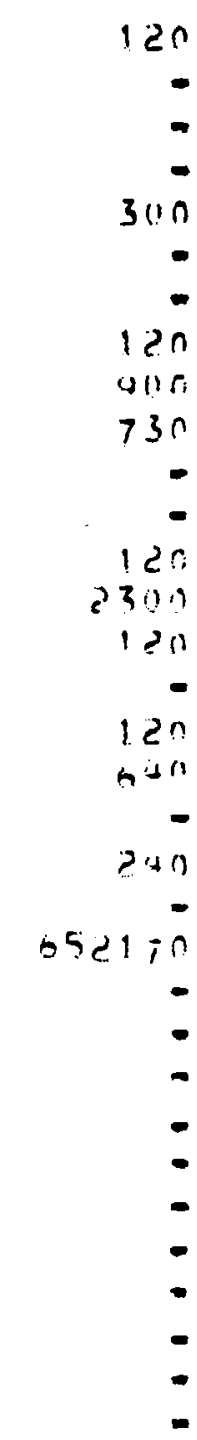 \\
\hline
\end{tabular}


TOTAL NUMBERS (ce $11 \mathrm{~s} / \mathrm{cm}^{2}$ ) OF THE PERIPHYTIC ALGA Cybellasinuata OBSERVED AT MONTICELLO

STATIUINS

\begin{tabular}{|c|c|c|c|c|c|c|c|}
\hline DATE & ${ }_{-\infty}^{2}$ & $\begin{array}{c}7 \\
-\infty\end{array}$ & $\begin{array}{c}9 \\
-\infty\end{array}$ & ${ }_{-\infty}^{3}$ & $\stackrel{h}{-\infty}$ & $\begin{array}{r}11 \\
-\infty\end{array}$ & $\begin{array}{r}3 \Delta \\
--0\end{array}$ \\
\hline 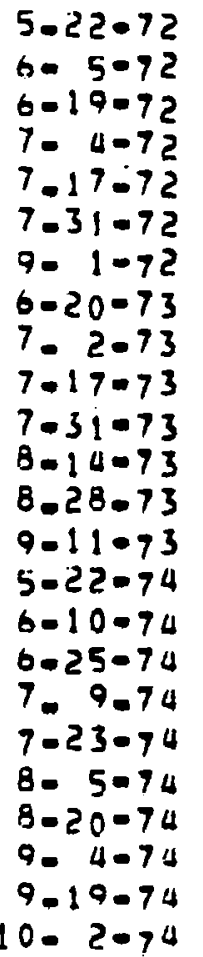 & $\begin{array}{r}120 \\
2072 \\
2316 \\
7300 \\
7300 \\
4500 \\
120 \\
8 \\
8640000 \\
\vdots \\
120 \\
0 \\
8601 \\
73800 \\
132650 \\
1000 \\
100 \\
: \\
0\end{array}$ & $\begin{array}{r}= \\
1350 \\
13680000 \\
120 \\
= \\
320 \\
= \\
103800 \\
= \\
13600 \\
= \\
=\end{array}$ & $\begin{array}{r}3700 \\
28500 \\
8700 \\
3100 \\
4500 \\
120 \\
120 \\
1476000 \\
240 \\
0 \\
0526 \\
6490 \\
5100 \\
40820 \\
6200 \\
= \\
-\end{array}$ & 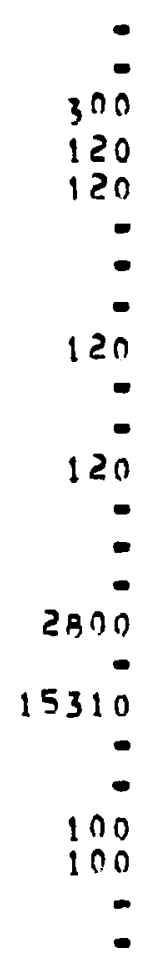 & $\begin{array}{r}1800 \\
4100 \\
86409 \\
\vdots \\
2700000 \\
3116000 \\
120 \\
640 \\
18 \\
2790 \\
27210 \\
- \\
10200 \\
10200\end{array}$ & $\begin{array}{r}1350 \\
1350 \\
1400 \\
= \\
2500000 \\
2400000 \\
120 \\
1200 \\
040 \\
2040 \\
- \\
10 \\
100 \\
1100\end{array}$ & 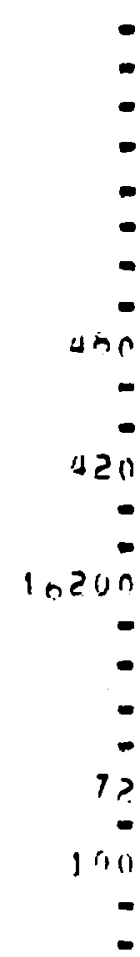 \\
\hline
\end{tabular}


TOTAL NUMBERS (cel1s $/ \mathrm{cm}^{2}$ ) OF THE PERIPHYTIC ALGA

Achnanthes laceolata OBSERVED AT MONTICELLLO

STATIONS

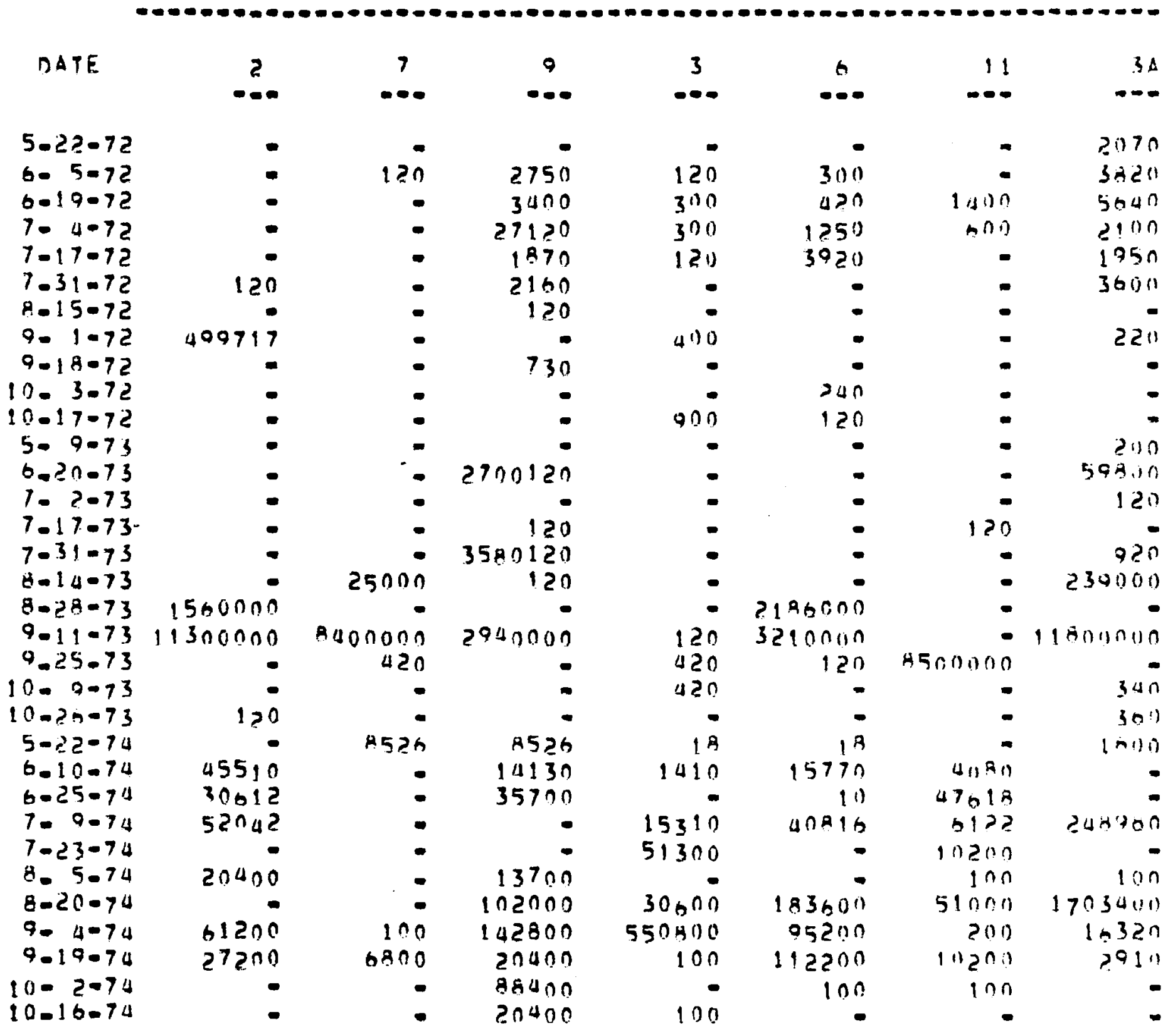


TOTAL NUMBERS (cel1s/ $/ \mathrm{cm}^{2}$ ) OF THE PERIPHYTIC ALGA

Gomthonema parvuTum OBSERVED AT MONTICELLO

STATIONS

\begin{tabular}{|c|c|c|c|c|c|c|c|}
\hline DATE & 2 & 7 & 9 & 3 & 6 & 11 & $3 A$ \\
\hline & 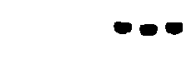 & $-\infty$ & $\bullet \bullet$ & $-=\infty$ & $-\infty$ & $-\infty$ & $-\infty$ \\
\hline $6.5-72$ & $9 \cap 0$ & 30270 & 2800 & 979000 & 6500 & $55(10$ & $2601 n$ \\
\hline $0-19-72$ & 731 & 17900 & 1100000 & 342400 & 1409909 & 23799 & - \\
\hline 7. $4-72$ & 804 & 2600 & 400 & 2100 & 1100 & 59025 & - \\
\hline $7.17-72$ & 120 & 2100 & - & 730 & 120 & $73 n$ & - \\
\hline $7.31-72$ & 731 & - & - & - & - & - & 18 900 \\
\hline $8-15-72$ & - & - & 2100 & - & - & - & $=$ \\
\hline 9.1072 & 784 & $1 ? 0$ & 730 & $73 n$ & 103800 & 120 & - \\
\hline $9-18-72$ & 1800 & 900 & 60000 & 78700 & 6704 & 23100 & 120 \\
\hline $10-3-72$ & 5400 & 2800 & 730 & $180 n$ & 15000 & 5400 & - \\
\hline 10.17 .72 & - & 2100 & 300 & 1901 & 730 & 550 & $12 r$ \\
\hline $11 \cdot 1 \cdot 72$ & - & 120 & - & 300 & - & - & 120 \\
\hline $11-28-72$ & - & 2800 & - & - & - & - & 121 \\
\hline $6-5-73$ & 1000 & 1400 & 480 & 1130 & 48000 & 36000 & - \\
\hline $6: 20-73$ & 4000000 & 585000 & - & - & $\bullet$ & - & 120 \\
\hline $7=2.73$ & 4300000 & 2.40 & 480 & 1400000 & 480 & $24 i$ & - \\
\hline $7-17=73$ & 240 & 120 & $24 n$ & $1 ? 0$ & $12^{n}$ & 240 & 92 \\
\hline $7-31-73$ & 320 & 120 & - & 120 & 120 & 241 & - \\
\hline 8.14 .73 & 420 & - & - & - & - & - & - \\
\hline$a-28=73$ & $\bullet$ & - & - & 120 & - & - & 27600 \\
\hline $9-11-73$ & 120 & $\bullet$ & - & $=$ & - & 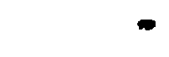 & 120110 \\
\hline $9-25-73$ & $900 \cap 00$ & 120 & $\bullet$ & 248 & - & - & 1300130180 \\
\hline $10=9.73$ & $\bullet$ & - & 240 & 120 & - & - & $24 i$ \\
\hline $5-22-74$ & & 220500 & 8526 & 43 & 1564 & - & - \\
\hline $0-10-74$ & 12300 & - & - & 890 & 6400 & - & - \\
\hline $6-25-7 u$ & 112244 & $=$ & 35710 & 40321 & 20409 & 455790 & - \\
\hline $7-9-74$ & 6802 & 494570 & 234690 & 100 & 40820 & 209321 & - \\
\hline $7=23-74$ & 100 & - & $=$ & - & 30600 & - & - \\
\hline $\begin{array}{l}8.5-74 \\
8.20-74\end{array}$ & 100 & - & 20400 & 6800 & - & - & - \\
\hline $9-11-74$ & $\ln 200^{\circ}$ & 20400 & $\therefore$ & - & 102000 & - & - \\
\hline $9.19-74$ & 40800 & 13600 & $2040 n$ & 1200 & 71.4000 & 123010 & - \\
\hline $10-2=74$ & - & - & 100 & 8160 & - & - & - \\
\hline 11.3 .74 & - & - & - & - & 100 & - & - \\
\hline
\end{tabular}




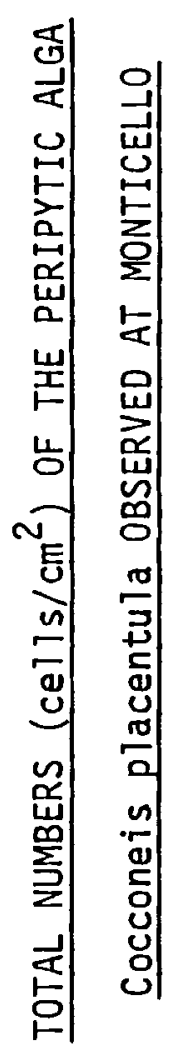

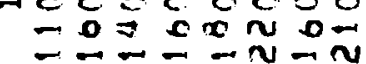

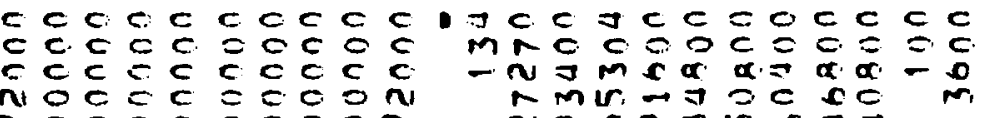 ñÉcE

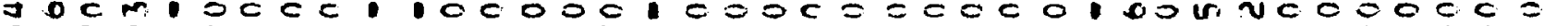 IN

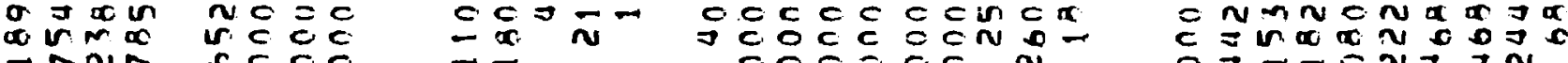

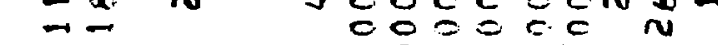 onin

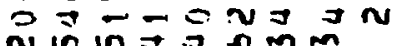 nin ing 0 in

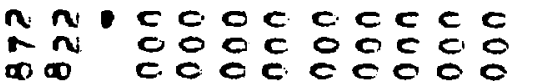
cect cecoce.

acoscecec=1

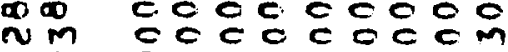

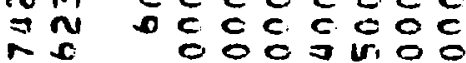

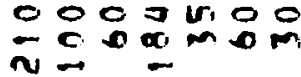

둥이

c. 0

in

$\Rightarrow$

c cico

c $50.0 \mathrm{~m}$

$c 0000$

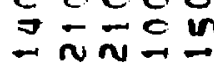

Nomclococe

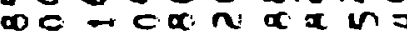
omm $a \rightarrow c m$

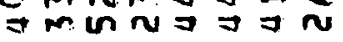
N

$n:$

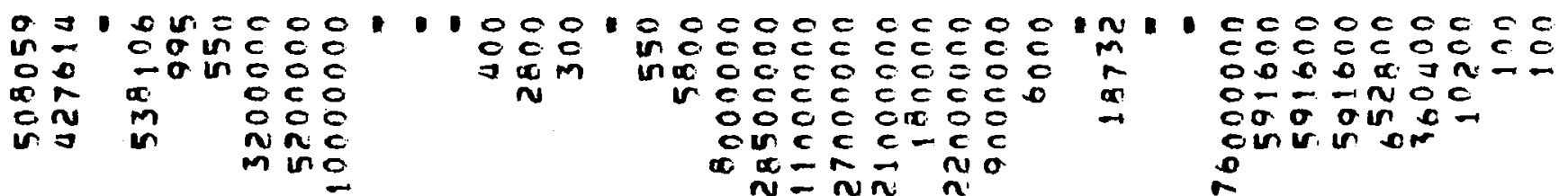

n: mñummaso cac-

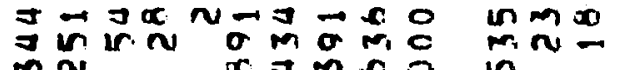
m in

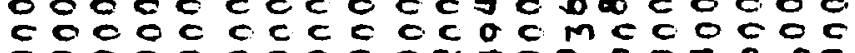

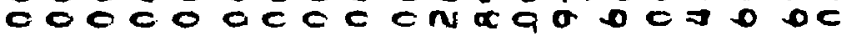
-

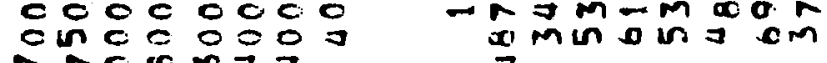

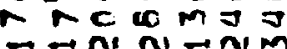

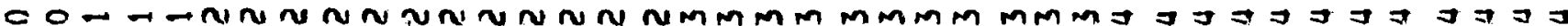

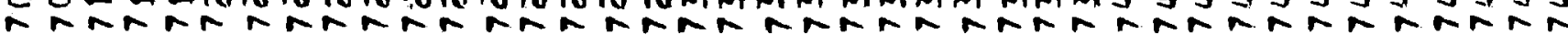
-

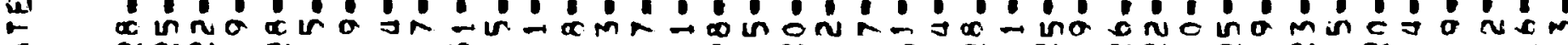

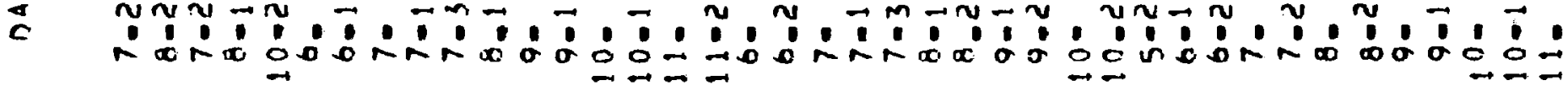


TOTAL NUMBERS (ce $17 \mathrm{~s} / \mathrm{cm}^{2}$ ) OF THE PERIPHYTIC ALGA

Chroococcus minimus OBSERVED AT MONTICELLO

STA TIONS

$n A T E$
$7-28-70$
$8-25-70$
$6=5-72$
$6-19-72$
$7-4-72$
$7-17-72$
$7-31-72$
$8-15-72$
$9-1-72$
$9-15-72$
$10-13-72$
$10-17-72$
$6-5-73$
$6-20-73$
$7-2-2-73$
$7-17-73$
$7-31-73$
$8-14-73$
$8-28-73$
$9-11-73$
$9-25-73$
$10-9-73$
$5-22-74$
$0-10-74$
$6-25-74$
$7-9-74$
$7-23-74$
$8-5-74$
$8-20-74$
$9-4-74$
$9-10-74$
$10-2-74$

2

6412834

635085

3700

4786608

234414

244565

1804347

495000

730

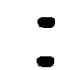

1000

8600000

Banonna

a 1000000

29000000

26000000

$1 ? 00000 n$

17000000

onก000

2000

3772000

551096

3333300

2754000

5,0000

4335000

714000

GE000

27200
3533833

635070

2300

$0730^{\circ}$

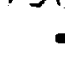

$-$

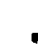

$-$

3700

1400

2340000

13700000

29nonon

34000000

2000000

50000

7 nonono

5000000

2小0

18732



9

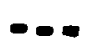

:

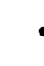

1500000

97800

508000

2000000

30600

3000000

1500

300

20000

32000000

$350000 n$

47000000

s00000n

4 1000000

$4100000 n$

10000001

10nonoon

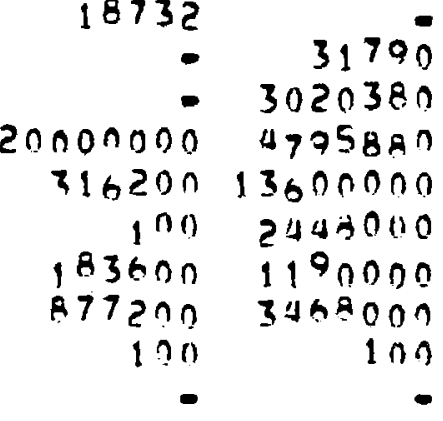

3

2407678

231453

34000

97800

127200

12720

730

34600

0

41000000

350000

32000000

34000000

41000000

1000000

-

$$
-
$$

1800

2060

4081000

285790

1013500

459000

- 18000

$476 n$ n

13400

1000

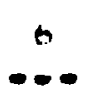

2049159

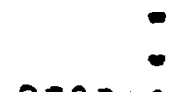

978260

168478

$79 B 912$

168476

3700

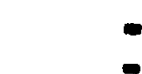

06000

$320 n n n n n$

$32000 n 0$

41000000

27000000

22000000

17000000

10000000

$100000 n$ n

420

10

05150

142900

4107110

1122000

217600

$73440 n$

14280 !n

765000

5100
11

$3 A$

2730921

55111

869515

217301

374090

-

120

120

$3 n 0$

12000

34000000

5100000

340 unurio

4.1000 inn

41000000

2 ?0000n

31000000

120

255100

1659050

1021140

2142000

2703000

1530000

1470000

357 11n

4000040

1600

300

65700

600110

I 4 ano

120

150000

169110

126550

10

$1320(1) \mathrm{r}$

20920 ?

- 
TOTAL NUMBERS (cel1s $/ \mathrm{cm}^{2}$ ) OF THE PERIPYTIC ALGA

Navicula cf. rhynchocephala OBSERVED AT MONTICELLO

STATIONS

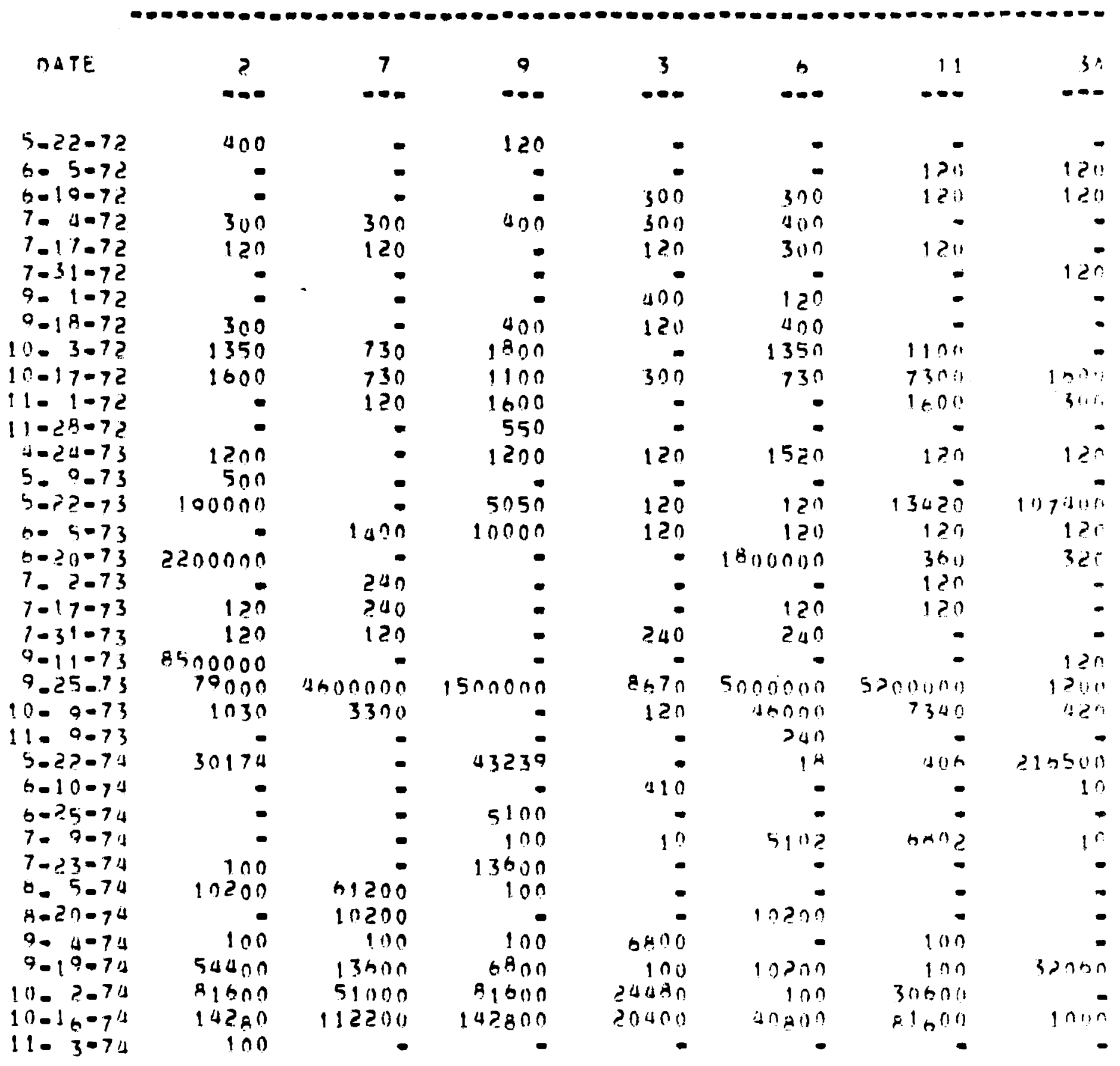


TOTAL NUMBERS $\left(\mathrm{ce} 17 \mathrm{~s} / \mathrm{cm}^{2}\right.$ ) OF THE PERIPHYTIC ALGA Synedria ulna

\section{OBSERVED AT MONTICELLO}

STLTITNS

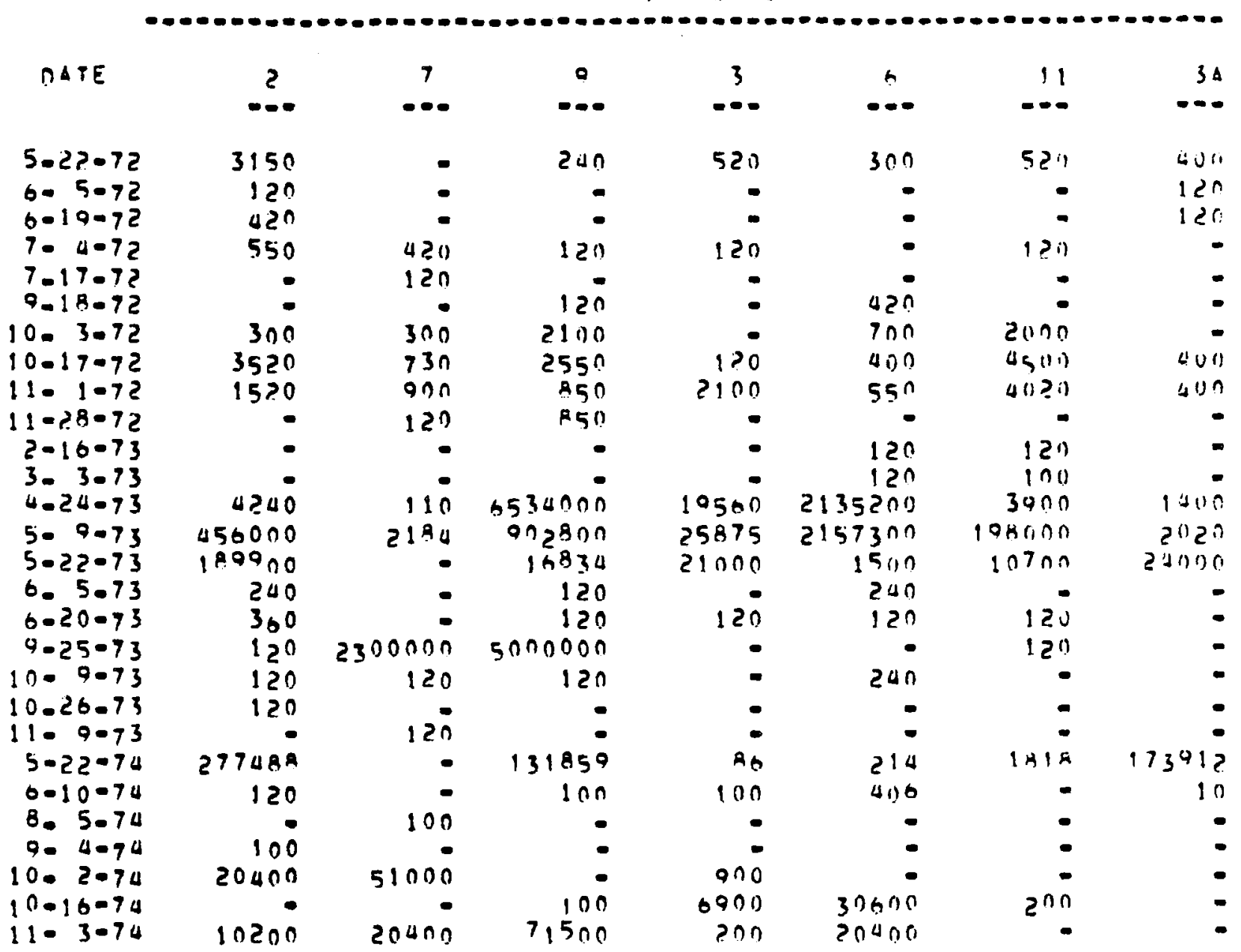


TOTAL NUMBERS (cel1s $/ \mathrm{cm}^{2}$ ) OF THE PERIPHYTIC ALGA Synedria ulna

OBSERVED AT MONTICELLO

STATITNS

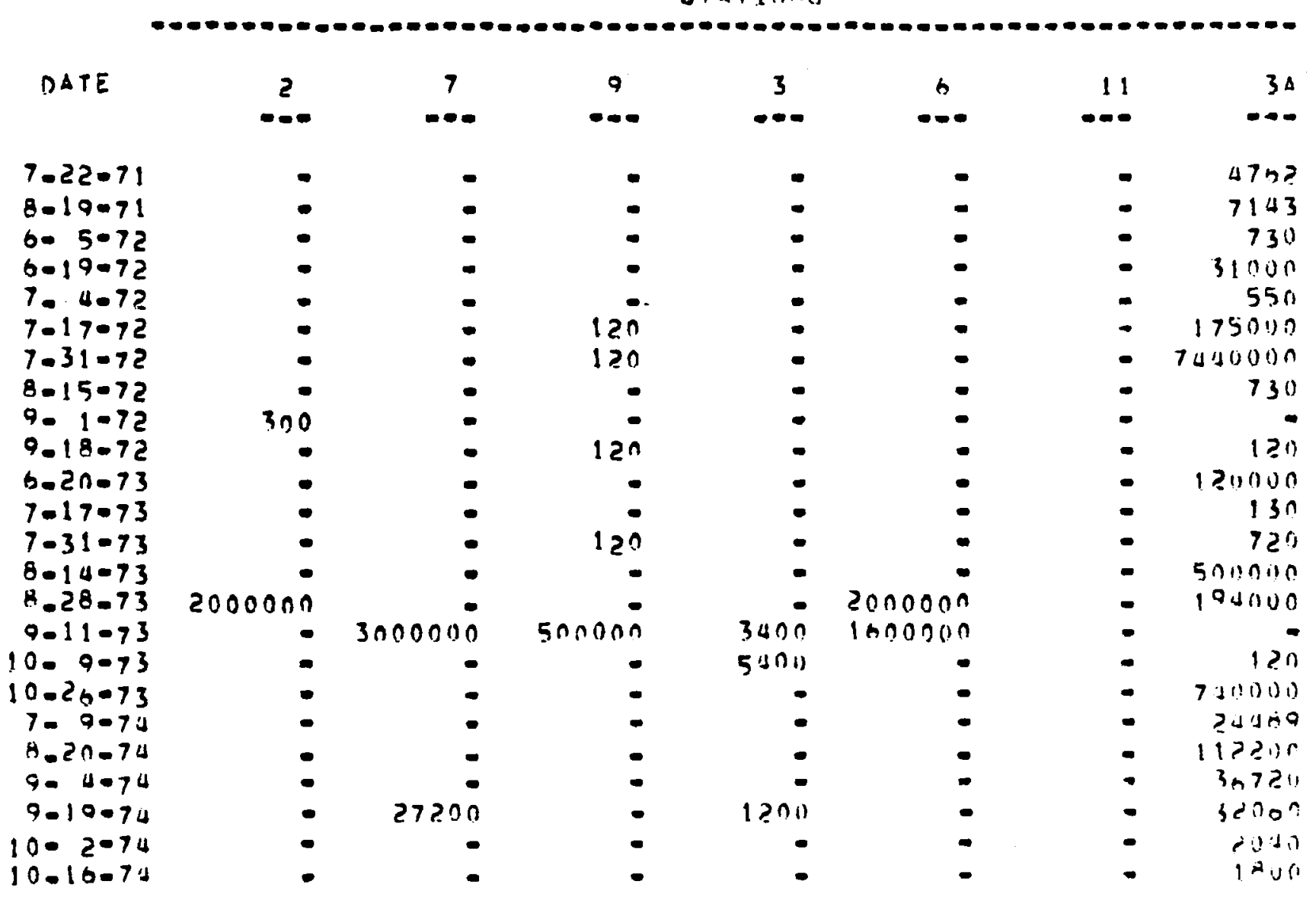


TOTAL NUMBERS (cel1s/ $\mathrm{cm}^{2}$ ) OF THE PERIPHYTIC ALGA

Synedria uina OBSERVED AT MONTICELLO

STATIONS

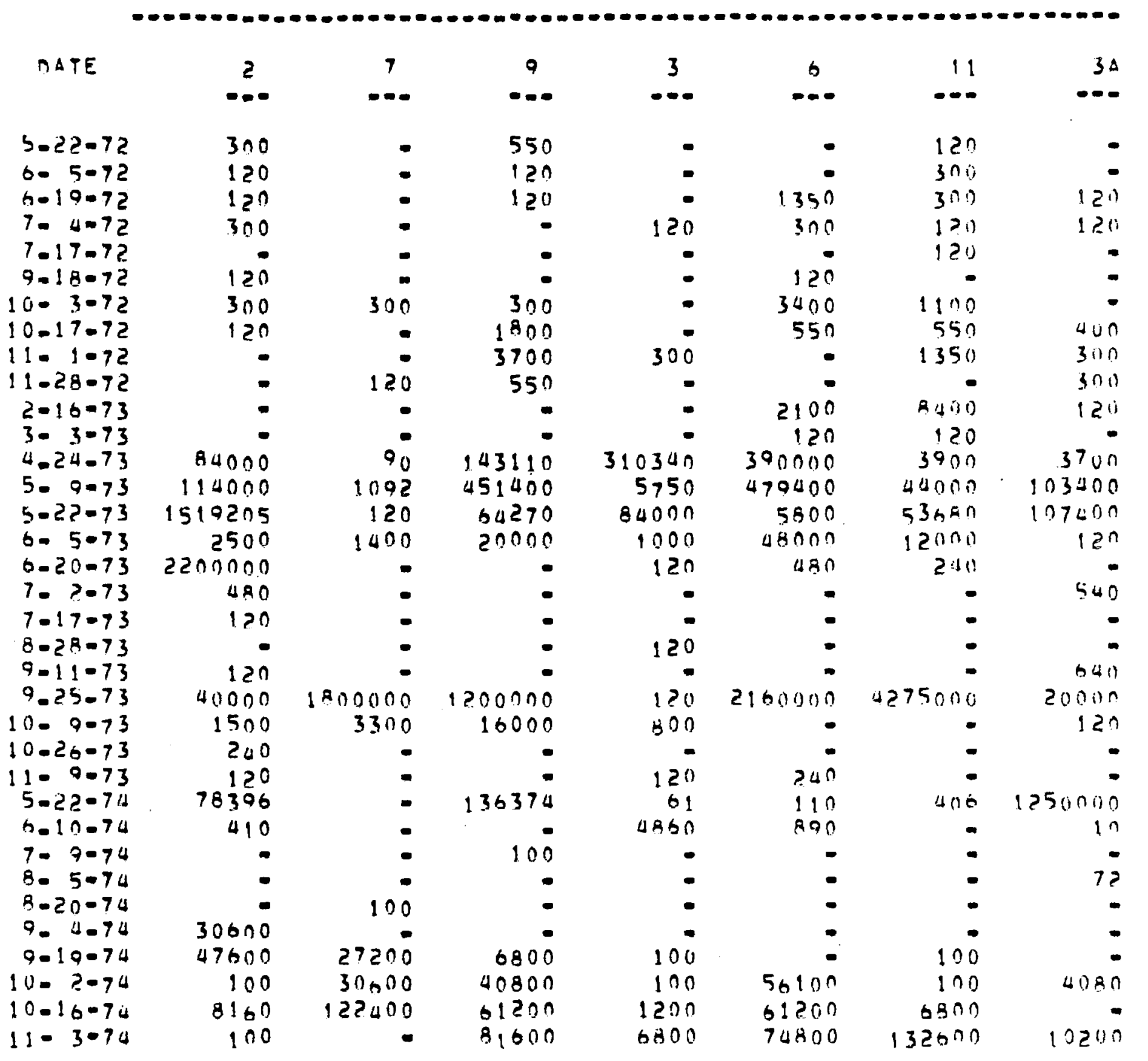


STATIONS

\begin{tabular}{|c|c|c|c|c|c|c|c|}
\hline DATE & 2 & $\begin{array}{c}7 \\
--\infty\end{array}$ & $\stackrel{9}{-\infty}$ & $\begin{array}{c}3 \\
-\infty-\infty\end{array}$ & 6 & $\begin{array}{r}11 \\
-\infty\end{array}$ & $\begin{array}{r}34 \\
-0-\end{array}$ \\
\hline $\begin{array}{l}7-28-70 \\
8-25-70 \\
7-22-71 \\
8-19-71\end{array}$ & $\begin{array}{r}406447 \\
95968 \\
366674 \\
324870\end{array}$ & $\begin{array}{r}330639 \\
211690 \\
3761980\end{array}$ & $\begin{array}{r}- \\
5064387 \\
6871566\end{array}$ & $\begin{array}{r}02097 \\
53629 \\
1400028 \\
4071510\end{array}$ & $\begin{array}{r}80442 \\
0 \\
12435963\end{array}$ & $\begin{array}{r}330230 \\
6101118 \\
9221613\end{array}$ & $\begin{array}{r}35715 \\
4335801\end{array}$ \\
\hline
\end{tabular}


TOTAL NUMBERS (cells $/ \mathrm{cm}^{2}$ ) OF THE PERIPHYTIC ALGA Synedria ulna

OBSERVED AT MONTICELLO

STATIONS

\begin{tabular}{|c|c|c|c|c|c|c|c|}
\hline DATE & $\stackrel{2}{2}$ & $\begin{array}{c}7 \\
-\infty\end{array}$ & $\stackrel{9}{0}$ & $\begin{array}{c}3 \\
-\infty\end{array}$ & $\stackrel{n}{-\infty}$ & $\begin{array}{r}11 \\
-\infty\end{array}$ & $\begin{array}{r}31 \\
-\infty-0\end{array}$ \\
\hline $\begin{array}{l}5-22-72 \\
6-19-72 \\
7-4-72 \\
7-17-72 \\
9-18-72 \\
10-3-72 \\
10-17-72 \\
11=1-72 \\
11-28-72 \\
2-16-73 \\
3-3-73 \\
4-24-73 \\
5-9-73 \\
5-22-73 \\
6-5-73 \\
6-20-73 \\
9-25-73 \\
10-9-73 \\
10-26-73 \\
5-22-74 \\
6-10-74 \\
9-40-74 \\
0-10-74 \\
10-2074 \\
10-16-74 \\
110-3074\end{array}$ & $\begin{array}{r}400 \\
300 \\
300 \\
0 \\
300 \\
21600 \\
4900 \\
0 \\
0 \\
2100 \\
796180 \\
949625 \\
2500 \\
240 \\
198000 \\
1030 \\
120 \\
43992 \\
100 \\
40800 \\
54400 \\
136000 \\
18360 \\
96900\end{array}$ & $\begin{array}{r}400 \\
120 \\
120 \\
120 \\
550 \\
2100 \\
2300 \\
0 \\
90 \\
2194 \\
1400 \\
6000000 \\
16670 \\
0 \\
0 \\
100 \\
20400 \\
91800 \\
163200 \\
204000\end{array}$ & $\begin{array}{r}120 \\
120 \\
120 \\
300 \\
1350 \\
3100 \\
550 \\
- \\
67600 \\
901480 \\
24000 \\
120 \\
12000000 \\
23000 \\
18732 \\
60 \\
6800 \\
40800 \\
214200 \\
132600\end{array}$ & $\begin{array}{r}120 \\
\vdots \\
4500 \\
\dot{-} \\
16000 \\
25755 \\
52500 \\
120 \\
420 \\
120 \\
10 \\
13600 \\
36720 \\
183600 \\
244800\end{array}$ & 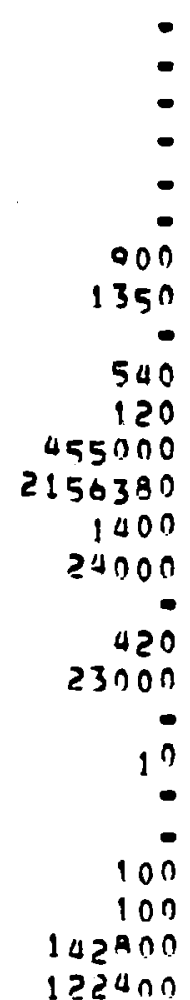 & $\begin{array}{r}120 \\
- \\
400 \\
7300 \\
3700 \\
- \\
180 \\
120 \\
1100 \\
107020 \\
46150 \\
481 \\
120 \\
14000 \\
80 \\
892 \\
- \\
100 \\
100 \\
224400 \\
1501\end{array}$ & $\begin{array}{r}12 n \\
400 \\
40 n \\
120 \\
120 \\
120 \\
45 \\
115000 \\
120 \\
97750 \\
420 \\
50347 \\
2040 \\
11200\end{array}$ \\
\hline
\end{tabular}




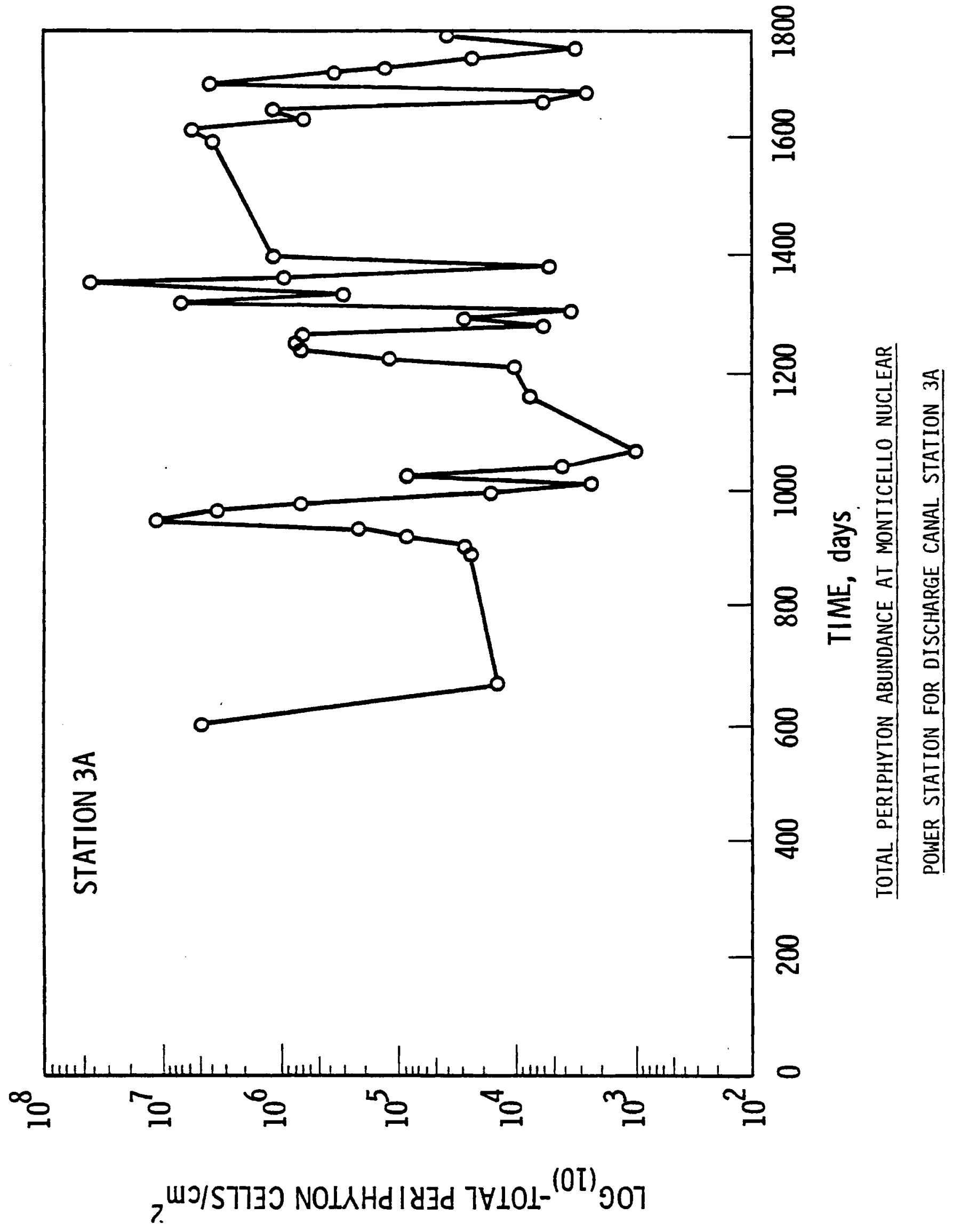




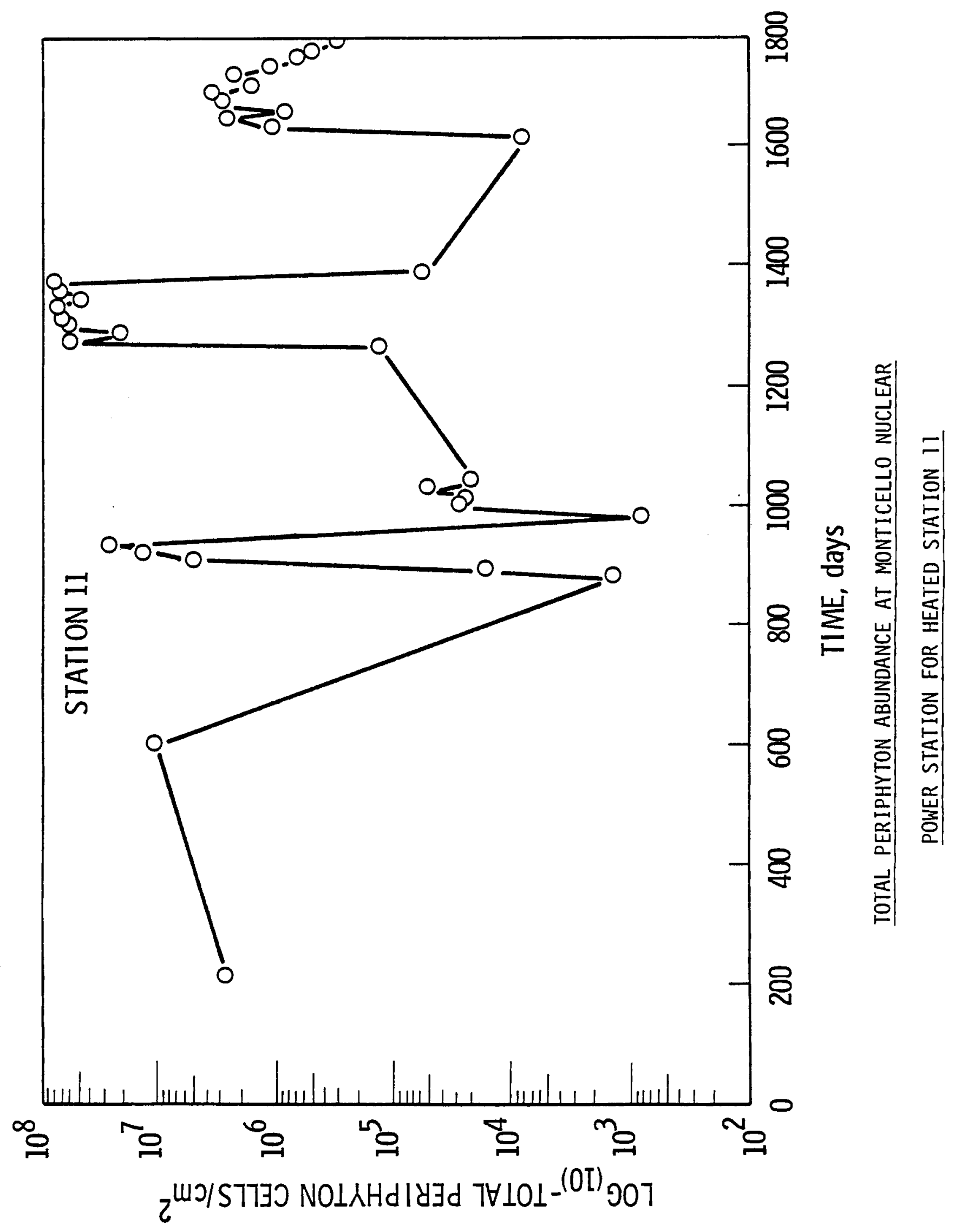




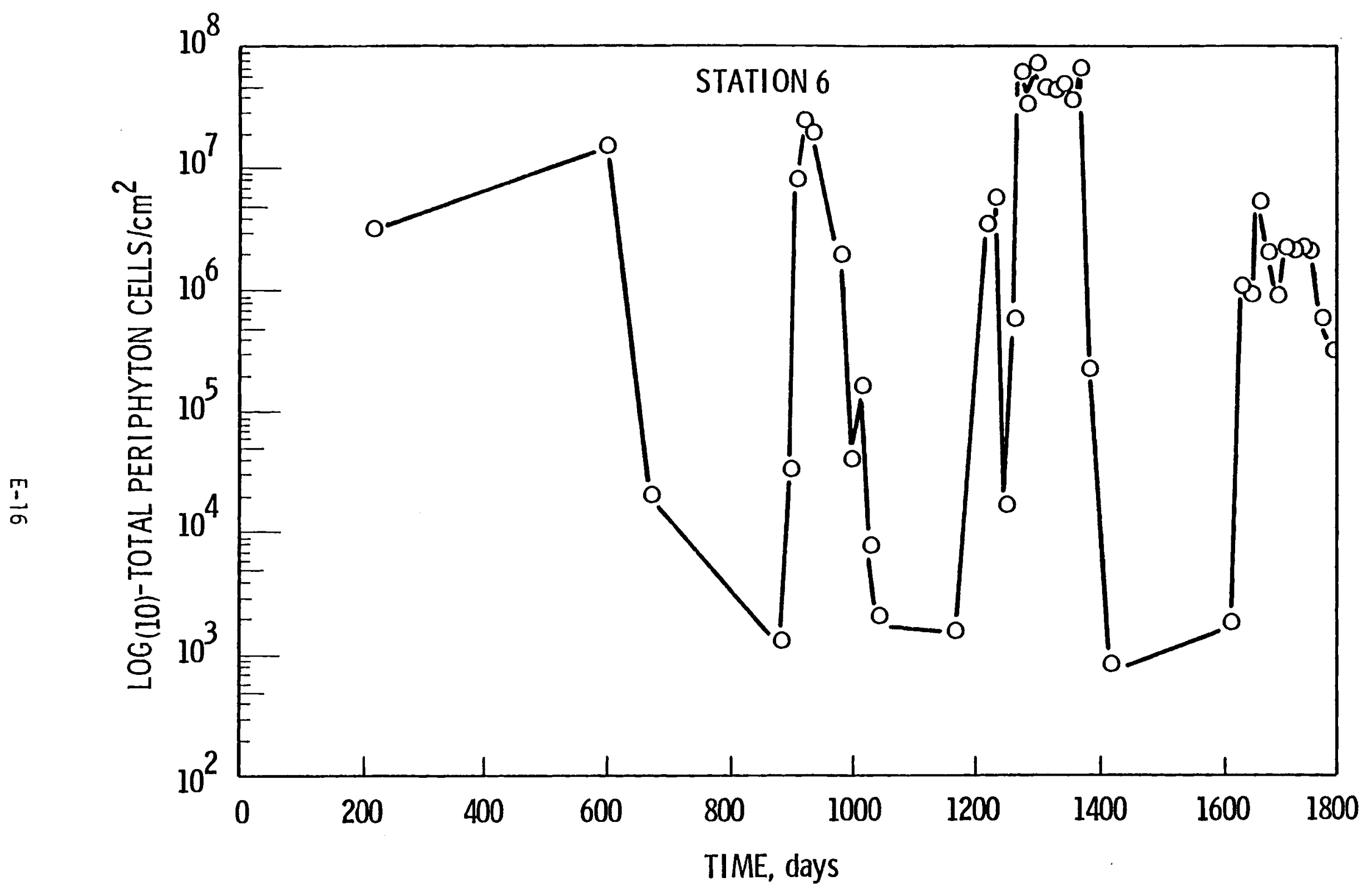

TOTAL PERIPHYTON ABUNDANCE AT MONTICELLO NUCLEAR

POWER STATION FOR HEATED STATION 6 


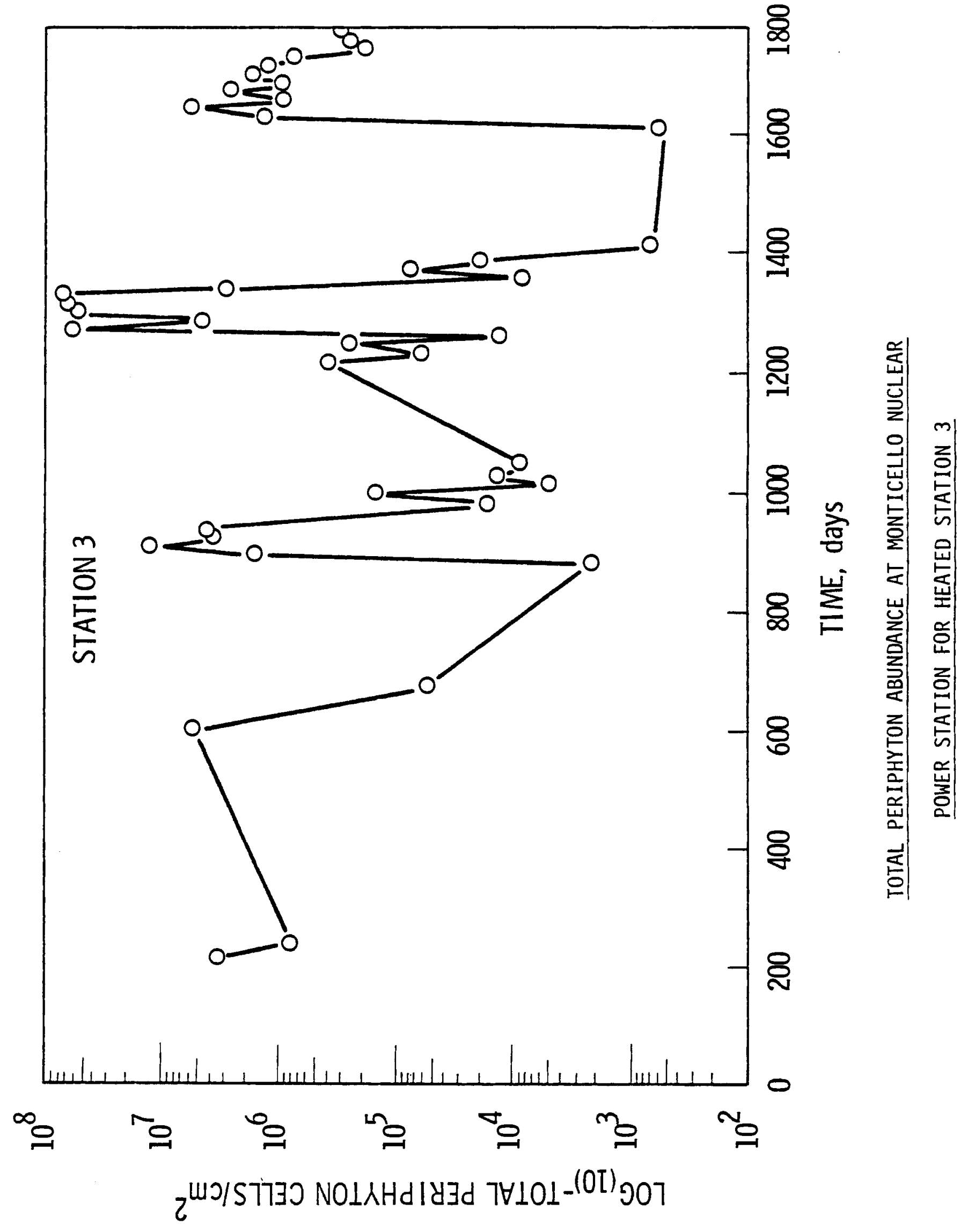




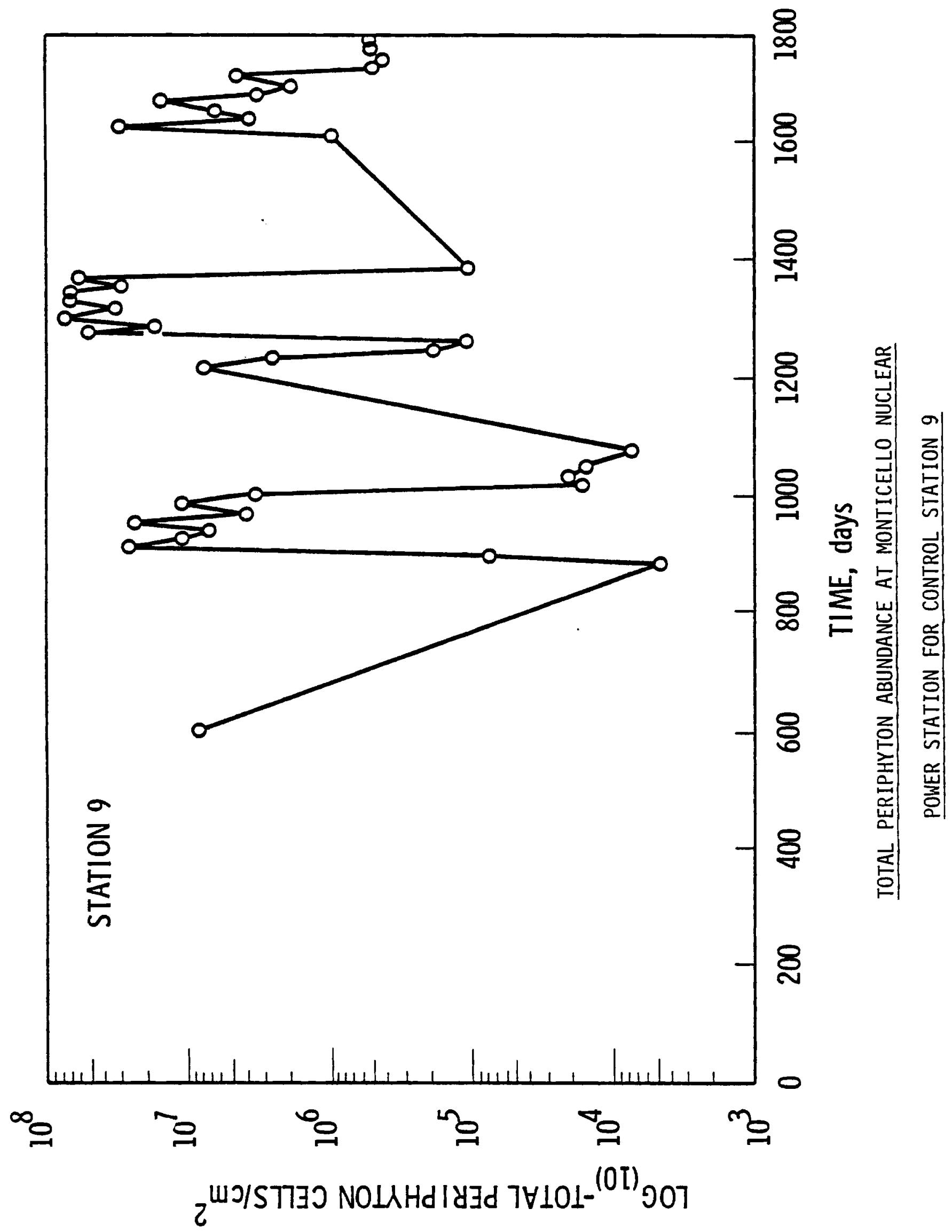




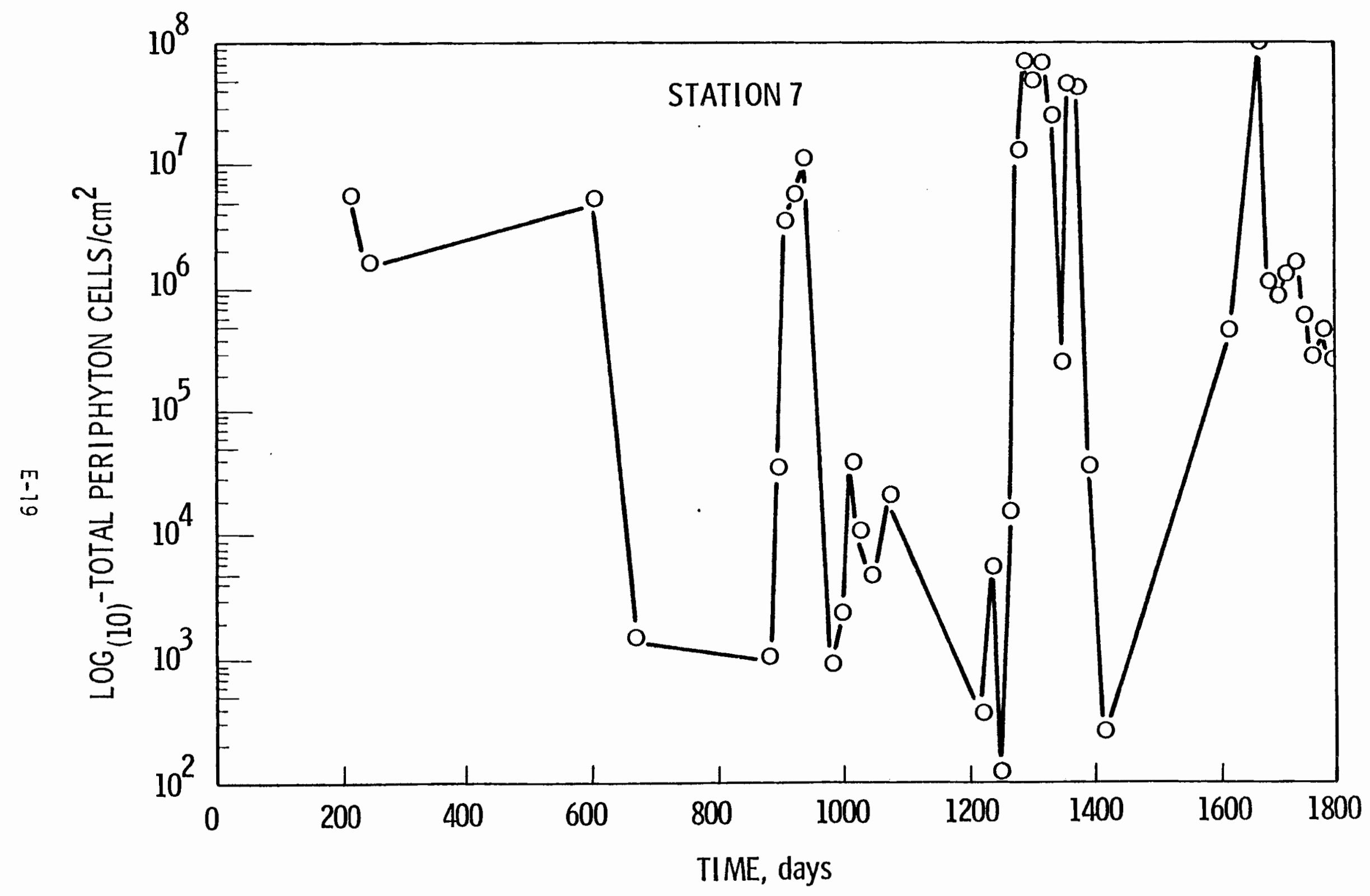

TOTAL PERIPHYTON ABUNDANCE AT MONTICELLO NUCLEAR 


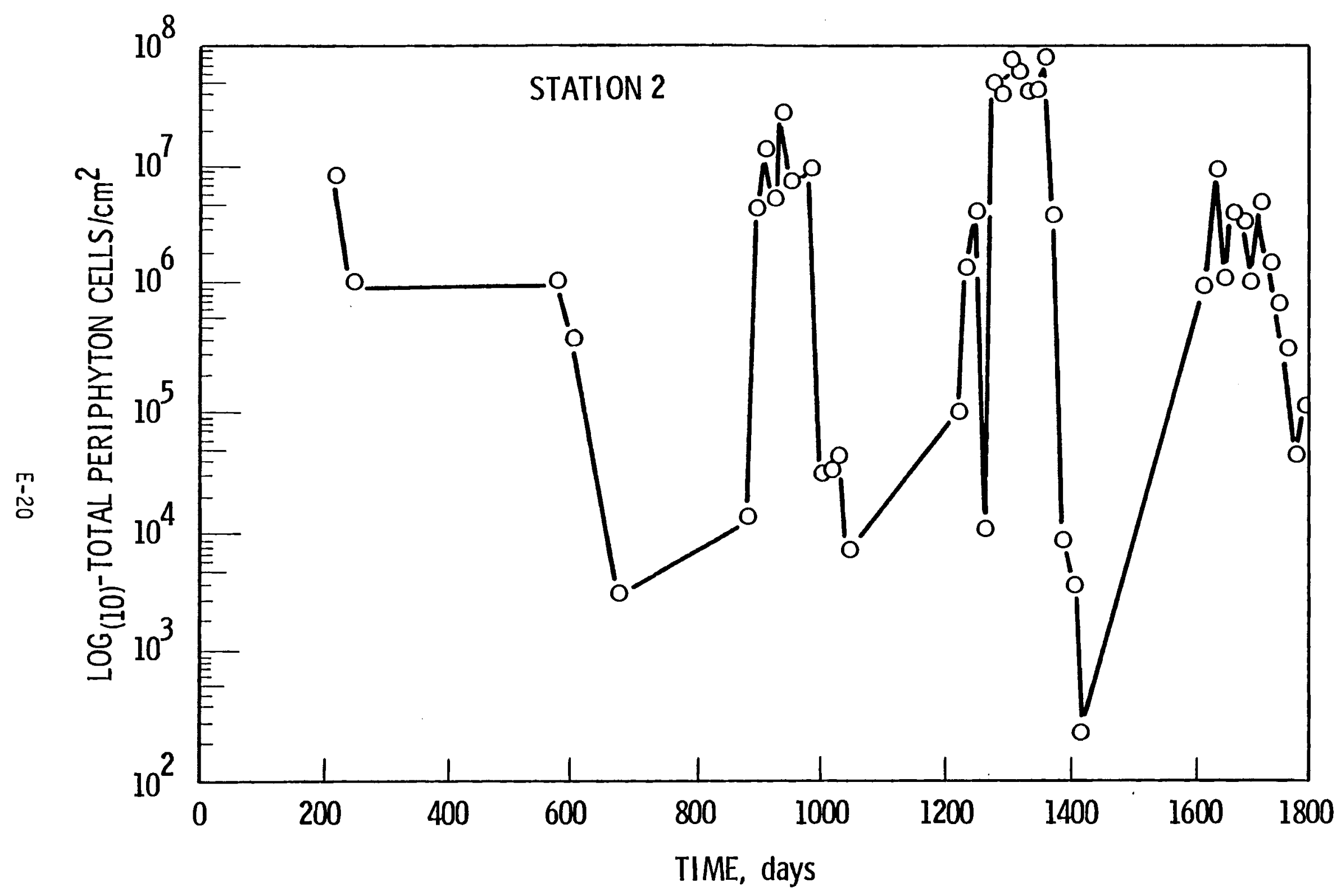

TOTAL PERIPHYTON ABUNDANCE AT MONTICELLO NUCLEAR

POWER STATION FOR CONTROL STATION 2 


\section{APPENDIX F}

\section{LOGARITHM (BASE 10) OF TOTAL PERIPHYTON}



Logarithm (Base 10) of Total Periphyton (ce11 s/ $\mathrm{cm}^{2}$ ) Arranged by Sampling Date, Season, and Distance $(\mathrm{ft})$ from Canal Station $3 \mathrm{~A}$

1972

\begin{tabular}{|c|c|c|c|c|c|c|c|}
\hline $\begin{array}{l}\text { Reactor } \\
\text { Status }\end{array}$ & $3 A(0)$ & $3(550)$ & $\begin{array}{r}\frac{s t}{6(2200)} \\
\end{array}$ & $\frac{\text { tions }}{7(2200)}$ & $9(3300)$ & $11(5300)$ & Sample Date \\
\hline On &.-- & 3.318 & 3.079 & 3000 & 3667 & 3134 & 5122 \\
\hline On & 4.379 & 6.157 & 4.465 & 4.498 & 4.855 & 4.195 & $6 / 5$ \\
\hline \multirow[t]{3}{*}{ On } & 4.393 & 7.052 & $\underline{6.838}$ & 6.508 & 7.374 & $\underline{6.654}$ & $6 / 19$ \\
\hline & 4.386 & 5.509 & 4.794 & 4.669 & 5.299 & 4.662 & Station Mean \\
\hline & 0.010 & 1.950 & 1.901 & 1.760 & 1.893 & 1.807 & Station Standard Deviation \\
\hline On & 4.899 & 6.519 & 7.324 & 6.717 & 7.006 & 7.081 & $7 / 4$ \\
\hline off & 5.301 & 6.560 & 7.235 & 7.001 & 6.820 & 7.397 & $7 / 17$ \\
\hline Off & 7.017 & --- & -- & --- & 7.329 & --- & $7 / 31$ \\
\hline On & 6.474 & --- & $-\cdots$ & -- & 6.549 & $-\cdots$ & $8 / 15$ \\
\hline On & 5.780 & 4.171 & 6.242 & 2.954 & 6.996 & 2.892 & $9 / 1$ \\
\hline \multirow[t]{3}{*}{ on } & 4.201 & 5.144 & 4.545 & 3.344 & 6.487 & 4.417 & $9 / 18$ \\
\hline & 5.612 & 5.599 & 6.337 & 5.0040 & 6.865 & $\overline{5.4468}$ & Station Mean \\
\hline & 1.034 & 1.157 & 1.291 & 2.151 & 0.315 & 2.165 & Station Standard Deviation \\
\hline
\end{tabular}

Fall (October, November, and December)

\begin{tabular}{|c|c|c|c|c|c|c|c|}
\hline On & 3.344 & 3.665 & 5.146 & 4.569 & 4.217 & 4.371 & $10 / 3$ \\
\hline on & 4.882 & 4.101 & 3.853 & 4.001 & 4.293 & 4.692 & $10 / 17$ \\
\hline On & 3.589 & 3.914 & 3.279 & 3.661 & 4.186 & 4.312 & $11 / 1$ \\
\hline \multirow[t]{3}{*}{ On } & 2.954 & $-\cdot$ & $\cdots$ & 4.284 & 3.857 & $\cdots$ & $11 / 28$ \\
\hline & 3.6923 & 3.8933 & 4.093 & 4.129 & 4.138 & 4.458 & Station Mean \\
\hline & 0.835 & 0.219 & 0.781 & 0.389 & 0.193 & 0.205 & Station Standard Deviation \\
\hline
\end{tabular}

\begin{tabular}{lcc}
\multicolumn{3}{c}{ Summary - 1972} \\
\hline Season & Mean & $\begin{array}{c}\text { Standard } \\
\text { Deviation }\end{array}$ \\
Spring & 4.916 & 1.153 \\
Summer & 5.871 & 1.414 \\
Fall & 4.056 & 0.539 \\
All Seasons & 5.047 & 1.451
\end{tabular}


Logarithm (Base 10) of Total Periphyton (cells $/ \mathrm{cm}^{2}$ ) Arranged by Sampling Date, Season, and Distance (ft) from Canal Station $3 \mathrm{~A}$

1973

\begin{tabular}{|c|c|c|c|c|c|c|c|}
\hline $\begin{array}{l}\text { Reactor } \\
\text { Status } \\
\end{array}$ & $3 A(0)$ & $3(550)$ & $\begin{array}{r}5 \\
6(2200) \\
\end{array}$ & $\begin{array}{l}\text { tions } \\
7(2200)\end{array}$ & $9(3300)$ & $11(5300)$ & Sample Date \\
\hline Off & 3.997 & 5.543 & 6.475 & 2.544 & 6.829 & $-\infty$ & $4 / 24$ \\
\hline Off & 5.033 & 4.760 & 6.681 & 3.737 & 6.354 & $\ldots$ & $5 / 9$ \\
\hline On & 5.776 & 5.364 & 4.182 & 2.079 & 5.226 & -- & $5 / 22$ \\
\hline On & 5.820 & 4.085 & 5.683 & 4.164 & 5.007 & 5.084 & $6 / 5$ \\
\hline \multirow[t]{3}{*}{ Off } & 5.780 & 7.736 & $\underline{7.725}$ & $\underline{7.068}$ & $\underline{7.662}$ & $\underline{7.712}$ & $6 / 20$ \\
\hline & 5.281 & 5.498 & 6.149 & 3.918 & 6.216 & 6.398 & Station Mean \\
\hline & 0.790 & 1.376 & 1.319 & 1.955 & 1.110 & $\cdots$ & Station Standard Deviation \\
\hline On & 3.740 & 6.614 & 7.457 & 7.797 & 7.189 & 7.298 & $7 / 2$ \\
\hline On & 4.417 & 7.687 & 7.813 & 7.653 & 7.829 & 7.733 & $7 / 17$ \\
\hline On & 3.530 & 7.788 & 7.635 & 7.708 & 7.461 & 7.789 & $7 / 31$ \\
\hline On & 6.803 & 7.821 & 7.623 & 7.353 & 7.789 & 7.813 & $8 / 14$ \\
\hline On & 5.421 & 6.418 & 7.640 & 5.364 & 7.789 & 7.636 & $8 / 28$ \\
\hline On & 7.566 & 3.906 & 7.510 & 7.628 & 7.415 & 7.811 & $9 / 11$ \\
\hline \multirow[t]{3}{*}{ On } & $\underline{5.954}$ & 4.855 & 7.783 & 7.616 & $\underline{7.720}$ & 7.852 & $9 / 25$ \\
\hline & 5.347 & 6.441 & 7.637 & 7.314 & 7.599 & 7.705 & Station Mean \\
\hline & 1.536 & 1.541 & 0.130 & 0.372 & 0.245 & 0.193 & Station Standard Deviation \\
\hline
\end{tabular}

Fal1 (October, November, and December)

\begin{tabular}{|c|c|c|c|c|c|c|c|}
\hline On & 3.695 & 4.257 & 5.295 & 4.527 & 4.994 & 4.736 & $10 / 9$ \\
\hline On & 3.994 & 2.806 & 2.857 & 2.380 & $-\cdots$ & $\cdots$ & $11 / 9$ \\
\hline & 3.845 & 3.531 & 4.076 & 3.454 & 4.994 & 4.736 & Station Mean \\
\hline
\end{tabular}

\begin{tabular}{|c|c|c|}
\hline Season & Mean & $\begin{array}{l}\text { Standard } \\
\text { Deviation }\end{array}$ \\
\hline Spring & 5.485 & 1.549 \\
\hline Summer & 7.007 & 1.254 \\
\hline Fall & 4.154 & 1.415 \\
\hline All Seasons & 6.061 & 1.707 \\
\hline
\end{tabular}


Logarithm (Base 10) of Total Periphyton (ce $11 \mathrm{~s} / \mathrm{cm}^{2}$ ) Arranged by Sampling Date, Season, and Distance (ft) from Canal Station $3 \mathrm{~A}$

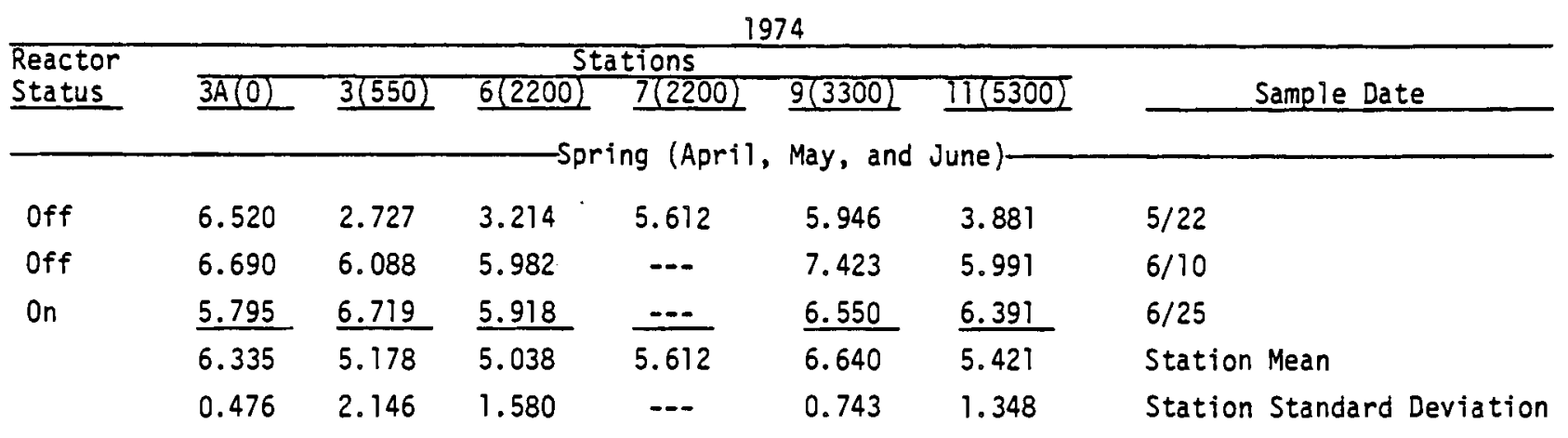

\begin{tabular}{llllllll} 
& \multicolumn{7}{c}{ Summer (July, August, and September) } \\
Off & 6.046 & 5.920 & 6.665 & 7.985 & 6.760 & 5.896 & $7 / 9$ \\
On & 3.697 & 6.377 & 6.252 & 6.000 & 7.143 & 6.432 & $7 / 23$ \\
On & 3.376 & 5.941 & 5.908 & 5.906 & 6.468 & 6.514 & $8 / 5$ \\
On & 6.570 & 6.196 & 6.295 & 6.108 & 6.259 & 6.199 & $8 / 20$ \\
On & 5.537 & 6.068 & 6.286 & 6.185 & 6.624 & 6.329 & $9 / 4$ \\
On & $\underline{5.089}$ & $\underline{5.842}$ & $\underline{6.308}$ & $\underline{5.758}$ & $\underline{5.672}$ & $\underline{6.009}$ & $9 / 19$ \\
& 5.053 & 6.057 & 6.286 & 6.324 & 6.488 & 6.230 & Station Mean \\
& 1.278 & 0.200 & 0.240 & 0.828 & 0.498 & 0.242 & Station Standard Deviation
\end{tabular}

Fall (October, November, and December)

$\begin{array}{llllllll}\text { On } & 4.361 & 5.247 & 6.288 & 5.427 & 5.578 & 5.795 & 10 / 2 \\ \text { On } & 3.479 & 5.356 & 5.708 & 5.633 & 5.672 & 5.678 & 10 / 16 \\ \text { On } & \frac{4.543}{4.127} & \frac{5.435}{5.346} & \frac{5.472}{5.822} & \frac{5.389}{5.483} & \underline{5.690} & \underline{5.471} & 11 / 3 \\ & 0.569 & 0.095 & 0.420 & 0.131 & 0.060 & 0.164 & \text { Station Standard Deviation }\end{array}$

\begin{tabular}{|c|c|c|}
\hline Season & Mean & $\begin{array}{l}\text { Standard } \\
\text { Deviation }\end{array}$ \\
\hline Spring & 5.715 & 1.307 \\
\hline Summer & 6.073 & 0.787 \\
\hline Fall & 5.346 & 0.635 \\
\hline Al] Seasons & 5.804 & 0.938 \\
\hline
\end{tabular}



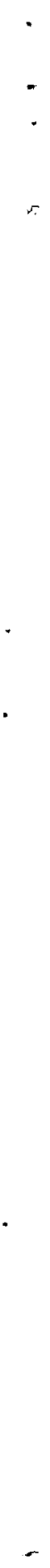


\section{APPENDIX G}

\section{ORIGINAL PRIMARY PRODUCTIVITY DATA}



PERIPHYTON CHLOROPHYLL-A $\left(\mu \mathrm{g} / \mathrm{cm}^{2}\right)$ VALUES

FOR MONTICELLO NUCLEAR POWER STATION

\begin{tabular}{|c|c|c|c|c|c|c|c|}
\hline DATE & $\begin{array}{c}\text { CONTR } \\
2 \\
\cdots-\end{array}$ & $\begin{array}{c}5 T \\
7 \\
---\end{array}$ & $\begin{array}{c}\text { ONS } \\
9 \\
--.--\end{array}$ & $\begin{array}{c}3 \\
---\end{array}$ & $\begin{array}{c}\text { ATED } \\
6 \\
-\cdots\end{array}$ & $\begin{array}{c}\text { STATIONS } \\
11 \\
=--\end{array}$ & $\begin{array}{l}3 A \\
-\infty\end{array}$ \\
\hline $\begin{array}{l}5-19-70 \\
5-29-70 \\
6-12-70 \\
6-26-70 \\
7-11-70 \\
7-28-70 \\
8-11-70 \\
8-26-70 \\
9-8-70 \\
9-24-70 \\
10-6-70 \\
10-20-70 \\
11-7-70\end{array}$ & $\begin{array}{r}1.010 \\
.650 \\
1.540 \\
2.420 \\
1.040 \\
1.090 \\
1.410 \\
2.250 \\
2.610 \\
4.930 \\
2.970 \\
13.450 \\
14.110\end{array}$ & $\begin{array}{l}.060 \\
.000 \\
.420 \\
.000 \\
.000 \\
.000 \\
.000 \\
2.020 \\
2.000 \\
3.030 \\
.890 \\
5.970 \\
7.250\end{array}$ & $\begin{array}{r}2.130 \\
1.160 \\
2.380 \\
4.060 \\
.710 \\
1.290 \\
.000 \\
.000 \\
1.920 \\
1.750 \\
.850 \\
1.260 \\
4.710\end{array}$ & $\begin{array}{r}.150 \\
.100 \\
.240 \\
1.550 \\
1.680 \\
1.430 \\
.000 \\
2.640 \\
2.180 \\
1.440 \\
1.650 \\
4.840 \\
14.270\end{array}$ & $\begin{array}{r}.560 \\
.320 \\
.550 \\
2.430 \\
1.690 \\
1.250 \\
1.120 \\
.000 \\
1.730 \\
2.140 \\
.770 \\
4.030 \\
8.040\end{array}$ & $\begin{array}{r}.000 \\
.260 \\
.840 \\
.110 \\
.630 \\
1.480 \\
1.390 \\
1.490 \\
2.100 \\
2.940 \\
2.170 \\
11.260 \\
2.750\end{array}$ & $\begin{array}{l}.000 \\
.000 \\
.000 \\
.000 \\
.000 \\
.000 \\
.000 \\
.000 \\
.000 \\
.000 \\
.000 \\
.000 \\
.000\end{array}$ \\
\hline $\begin{array}{l}2-16-71 \\
3-4-71 \\
5-13-71 \\
5-27-71 \\
6-10-71 \\
6-24-71 \\
7-9-71 \\
7-22-71 \\
8-5-71 \\
8-19-71 \\
9-2-71 \\
9-15-71 \\
9-30-71 \\
10-14-71 \\
10-28-71\end{array}$ & $\begin{array}{r}.020 \\
.000 \\
1.690 \\
.250 \\
1.530 \\
3.780 \\
2.490 \\
2.520 \\
1.380 \\
1.360 \\
1.240 \\
.670 \\
.220 \\
2.870 \\
4.400\end{array}$ & $\begin{array}{r}.000 \\
.000 \\
.050 \\
.100 \\
.230 \\
1.660 \\
.000 \\
.000 \\
2.660 \\
2.230 \\
1.480 \\
1.990 \\
1.680 \\
1.750 \\
.870\end{array}$ & $\begin{array}{r}.000 \\
.000 \\
2.060 \\
2.600 \\
.950 \\
3.300 \\
2.610 \\
3.150 \\
2.910 \\
2.620 \\
2.340 \\
2.600 \\
3.160 \\
2.880 \\
.000\end{array}$ & $\begin{array}{l}.010 \\
.000 \\
.670 \\
.380 \\
.000 \\
3.190 \\
1.450 \\
3.020 \\
2.360 \\
2.650 \\
1.750 \\
1.820 \\
1.350 \\
.310 \\
1.110\end{array}$ & $\begin{array}{l}.020 \\
.000 \\
.570 \\
.380 \\
.870 \\
4.610 \\
2.240 \\
1.700 \\
2.920 \\
2.230 \\
1.110 \\
1.070 \\
.500 \\
2.160 \\
.920\end{array}$ & $\begin{array}{r}.000 \\
.000 \\
.140 \\
.070 \\
.010 \\
.490 \\
.450 \\
.770 \\
1.490 \\
2.380 \\
1.720 \\
2.040 \\
1.030 \\
.260 \\
.000\end{array}$ & $\begin{array}{r}.000 \\
.000 \\
.870 \\
.310 \\
1.680 \\
3.650 \\
.260 \\
1.160 \\
3.020 \\
.370 \\
.170 \\
.630 \\
.730 \\
.650 \\
.450\end{array}$ \\
\hline $\begin{array}{r}3-16-72 \\
5-22-72 \\
6-5-72 \\
6-19-72 \\
7-4-72 \\
7-17-72 \\
7-31-72 \\
8-15-72 \\
9-1-72 \\
9-18-72 \\
10-3-72 \\
10-16-72 \\
11-1-72 \\
11-28-72\end{array}$ & $\begin{array}{r}.000 \\
.750 \\
.650 \\
1.050 \\
1.580 \\
3.360 \\
3.300 \\
.000 \\
5.720 \\
1.130 \\
2.790 \\
2.410 \\
1.550 \\
.000\end{array}$ & $\begin{array}{r}.000 \\
.070 \\
.090 \\
.360 \\
1.740 \\
2.160 \\
.000 \\
.000 \\
.470 \\
.470 \\
1.090 \\
.640 \\
1.660 \\
.080\end{array}$ & $\begin{array}{r}.020 \\
.490 \\
.460 \\
2.440 \\
2.530 \\
2.810 \\
2.310 \\
2.050 \\
2.690 \\
1.610 \\
2.610 \\
1.780 \\
.720 \\
.230\end{array}$ & $\begin{array}{r}.000 \\
.030 \\
.290 \\
.770 \\
1.290 \\
1.860 \\
.000 \\
.000 \\
1.060 \\
.530 \\
.960 \\
.730 \\
8.940 \\
.000\end{array}$ & $\begin{array}{r}.000 \\
.170 \\
.360 \\
1.360 \\
2.190 \\
2.760 \\
.000 \\
.000 \\
1.030 \\
1.690 \\
3.860 \\
2.860 \\
5.110 \\
.150\end{array}$ & $\begin{array}{r}.000 \\
.160 \\
.440 \\
2.040 \\
2.000 \\
2.200 \\
.000 \\
.000 \\
.760 \\
1.720 \\
3.500 \\
2.500 \\
5.570 \\
.000\end{array}$ & $\begin{array}{r}.000 \\
.360 \\
.210 \\
1.680 \\
.210 \\
.960 \\
3.350 \\
.340 \\
.810 \\
.150 \\
.040 \\
.130 \\
.030 \\
.060\end{array}$ \\
\hline
\end{tabular}




\section{PERIPHYTON CHLOROPHYLL-A $\left(\mathrm{\mu g} / \mathrm{cm}^{2}\right)$ VALUES}

FOR MONTICELLO NUCLEAR POWER STATION

\section{DATE}

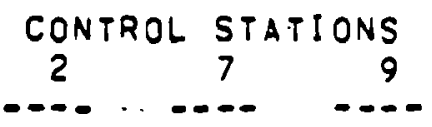

$1-16-73$
$2-16-73$
$3-5-73$
$4-24-73$
$5-9-73$
$5-22-73$
$6-5-73$
$6-20-73$
$7-2-73$
$7-17-73$
$7-31-73$
$8-14-73$
$8-28-73$
$9-11-73$
$9-24-73$
$0-9-73$
$0-26-73$
$1-9-73$
$1-23-73$

\begin{tabular}{|c|c|c|}
\hline $\begin{array}{r}.000 \\
.000 \\
.000 \\
3.010 \\
2.350 \\
.860 \\
.550 \\
2.880 \\
3.160 \\
2.400 \\
2.170 \\
2.410 \\
1.650 \\
2.070 \\
.580 \\
.060 \\
.690 \\
.150 \\
.070\end{array}$ & $\begin{array}{r}.000 \\
.000 \\
.000 \\
.650 \\
1.290 \\
.130 \\
.140 \\
1.940 \\
2.370 \\
2.640 \\
2.190 \\
2.270 \\
.770 \\
1.970 \\
1.540 \\
.500 \\
.000 \\
.050 \\
.010\end{array}$ & $\begin{array}{r}.000 \\
.000 \\
.000 \\
7.780 \\
3.630 \\
1.910 \\
3.420 \\
2.900 \\
2.970 \\
3.650 \\
1.290 \\
2.010 \\
2.410 \\
2.260 \\
3.440 \\
3.340 \\
.000 \\
.110 \\
.030\end{array}$ \\
\hline $\begin{array}{r}1.040 \\
2.470 \\
2.030 \\
2.290 \\
2.200 \\
2.220 \\
2.050 \\
3.170 \\
2.370 \\
3.340 \\
.910 \\
3.580\end{array}$ & $\begin{array}{r}.000 \\
.000 \\
.380 \\
.960 \\
.920 \\
1.850 \\
2.400 \\
2.810 \\
4.100 \\
2.250 \\
3.760 \\
6.010\end{array}$ & $\begin{array}{l}1.760 \\
2.220 \\
2.370 \\
3.010 \\
1.770 \\
2.770 \\
3.040 \\
5.310 \\
2.770 \\
2.000 \\
3.710 \\
3.490\end{array}$ \\
\hline
\end{tabular}

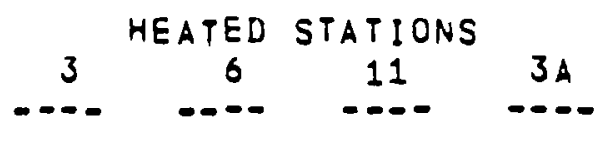

$\begin{array}{rrrr}.000 & .000 & .000 & .090 \\ .000 & 2.040 & .000 & .870 \\ .000 & .830 & .000 & .830 \\ 2.380 & 4.280 & 2.350 & 3.300 \\ 2.330 & 3.260 & 6.120 & 1.440 \\ .970 & .900 & .700 & 1.940 \\ .810 & 2.210 & .510 & .080 \\ 2.160 & 3.680 & 2.880 & 1.330 \\ 2.220 & 2.750 & 2.470 & .480 \\ 2.410 & 2.260 & 2.450 & .160 \\ 1.710 & 1.810 & 2.230 & .420 \\ 2.140 & 1.970 & 2.360 & .680 \\ 1.040 & 1.960 & 2.590 & .070 \\ 2.100 & 2.570 & 2.430 & .130 \\ 1.870 & 2.180 & 3.620 & .270 \\ .650 & .910 & 1.090 & 1.000 \\ .000 & .000 & .000 & .510 \\ .040 & .110 & .030 & .120 \\ .010 & .030 & .030 & .060\end{array}$

$\begin{array}{rrrr}.040 & .140 & .030 & 1.430 \\ 1.090 & 2.400 & 1.290 & .450 \\ 1.930 & 1.570 & 1.250 & .390 \\ 1.460 & 2.210 & 1.890 & 4.610 \\ .740 & 2.300 & 1.150 & .920 \\ 2.150 & 2.050 & 2.180 & .670 \\ 2.030 & 3.410 & 2.350 & 1.800 \\ 4.360 & 2.020 & 2.480 & .560 \\ 5.440 & 3.120 & 4.400 & .000 \\ 2.230 & 1.210 & 1.660 & .220 \\ 3.460 & 5.320 & 4.150 & .000 \\ 4.080 & 2.350 & 2.840 & .890\end{array}$




\section{STATISTICAL ANALYSIS OF REPLICATE}

DETERMINATIONS OF CHLOROPHYLL-A $\left(\mu \mathrm{g} / \mathrm{cm}^{2}\right)$

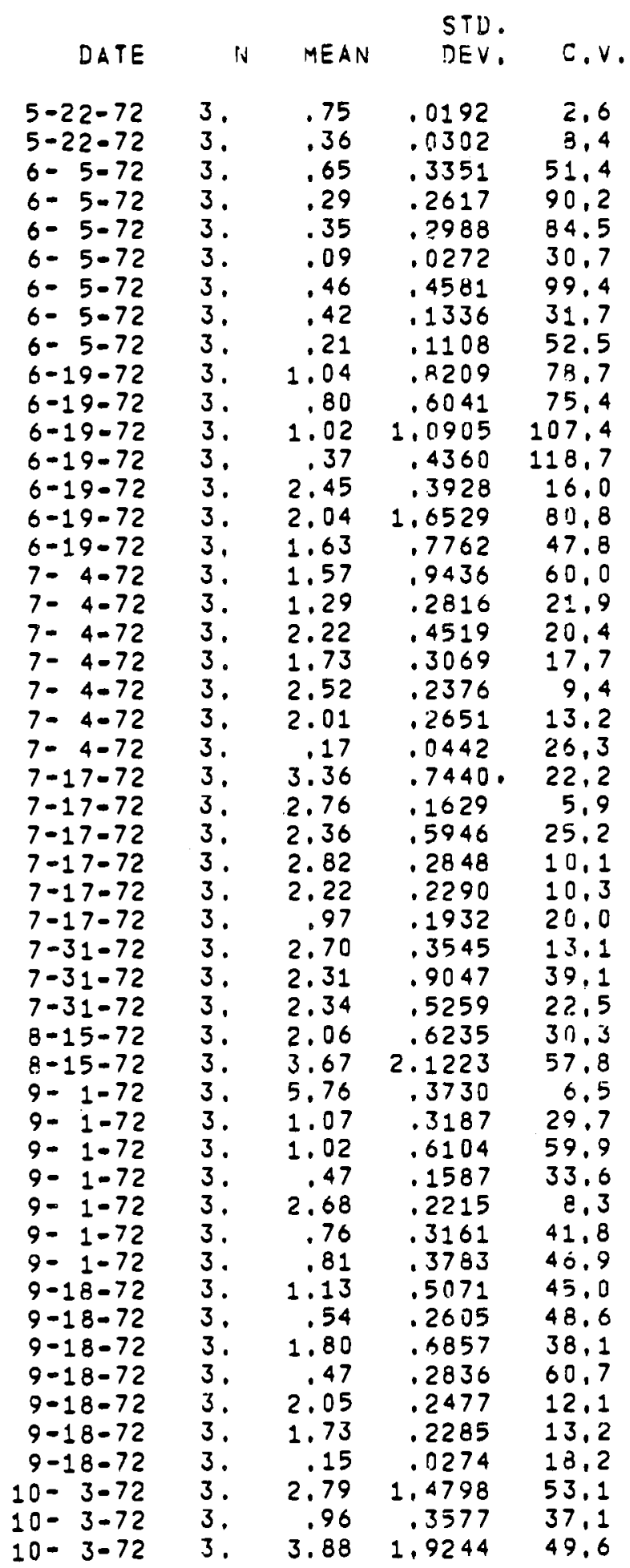




\section{STATISTICAL ANALYSIS OF REPLICATE}

\section{DETERMINATIONS OF CHLOROPHYLL-A $\left(\mu \mathrm{g} / \mathrm{cm}^{2}\right)$}

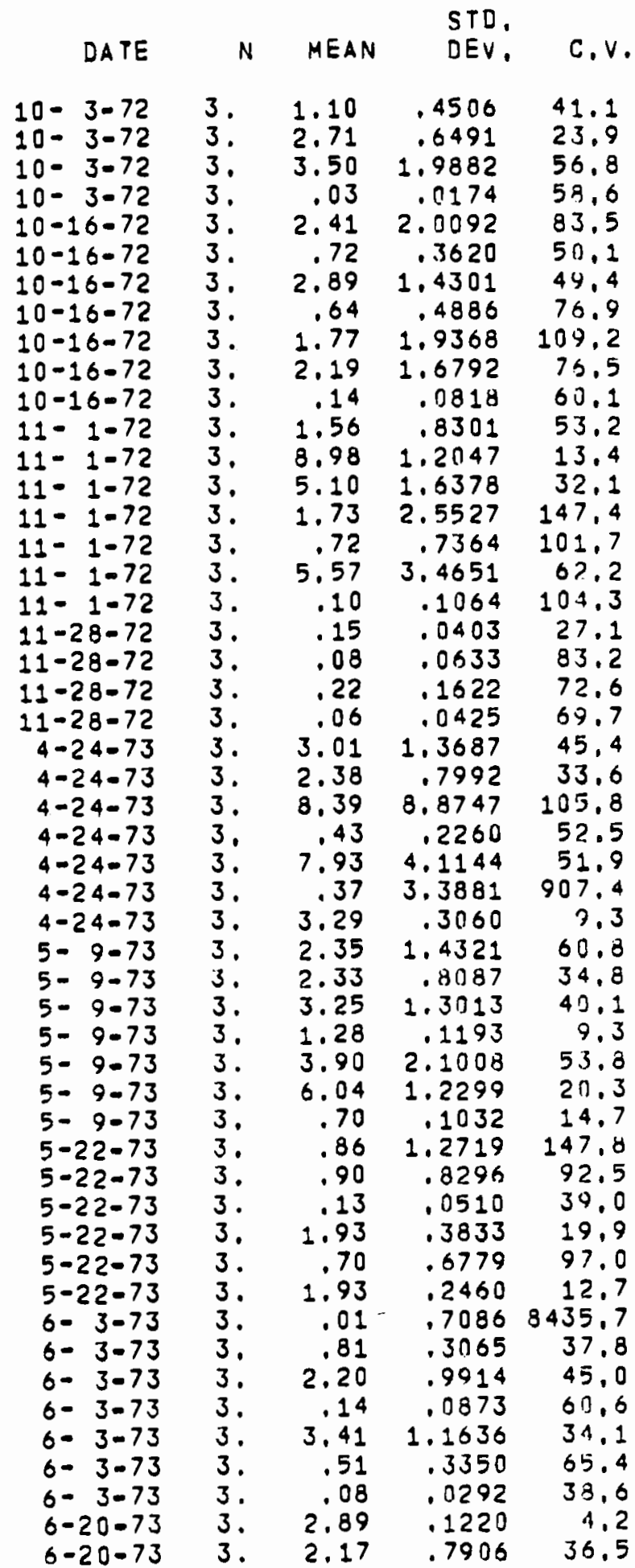


STATISTICAL ANALYSIS OF REPLICATE DETERMINATIONS OF CHLOROPHYLL-A $\left(\mu \mathrm{g} / \mathrm{cm}^{2}\right)$

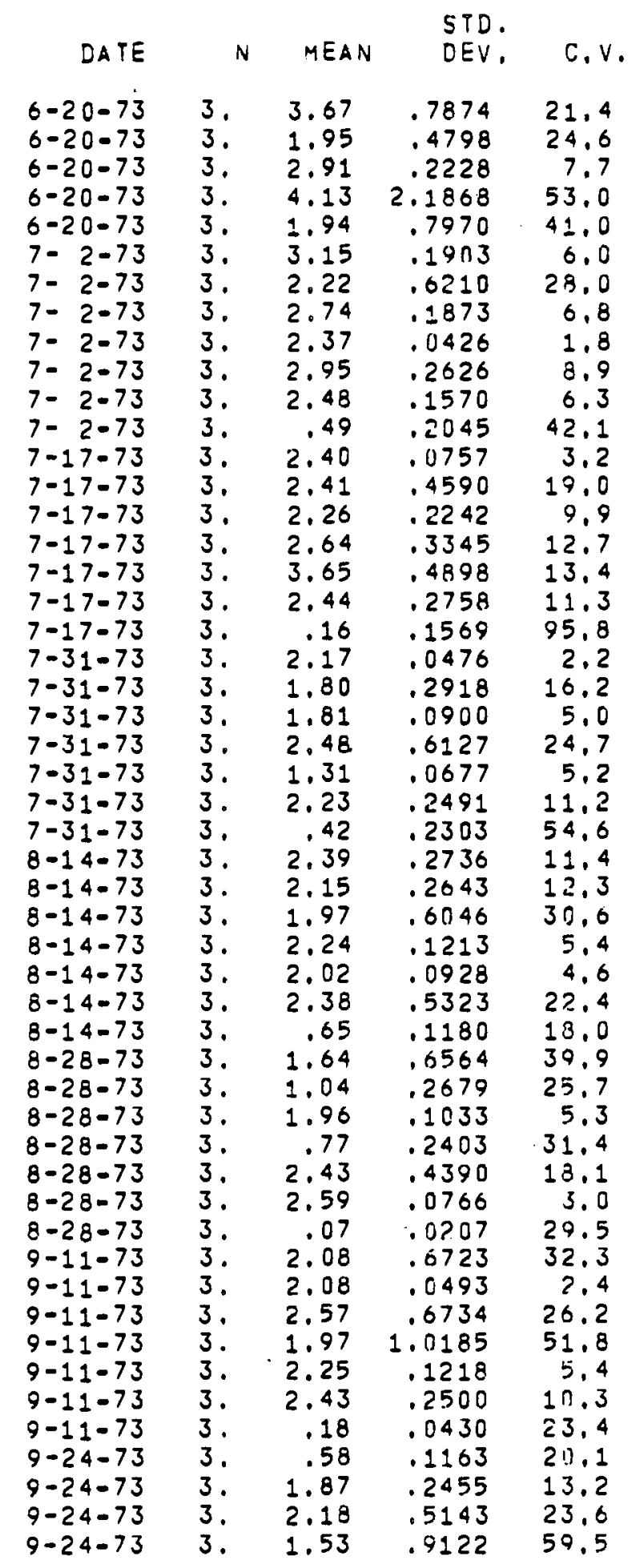




\section{STATISTICAL ANALYSIS OF REPLICATE}

DETERMINATIONS OF CHLOROPHYLL-A $\left(\mu \mathrm{g} / \mathrm{cm}^{2}\right)$

\begin{tabular}{|c|c|c|c|c|}
\hline DATE & $\mathbf{N}$ & MEAN & $\begin{array}{l}\text { STD. } \\
\text { DEV. }\end{array}$ & C.V. \\
\hline $\begin{array}{l}9-24-73 \\
9-24-73 \\
9-24-73\end{array}$ & $\begin{array}{l}3 . \\
3 . \\
3\end{array}$ & $\begin{array}{r}2.08 \\
3.63 \\
.27\end{array}$ & $\begin{array}{r}2.3271 \\
1.1537 \\
.1108\end{array}$ & $\begin{array}{r}111.9 \\
31.8 \\
40.8\end{array}$ \\
\hline $\begin{array}{l}10-9-73 \\
10-9-73\end{array}$ & 3. & $\begin{array}{r}-.01 \\
.64\end{array}$ & $\begin{array}{l}.1531-1 \\
.4778\end{array}$ & $\begin{array}{r}354.9 \\
74.1\end{array}$ \\
\hline $10-9-73$ & 3. & .91 & .2192 & 24.1 \\
\hline $\begin{array}{l}10-9-73 \\
10-9-73\end{array}$ & 3. & .41 & .0702 & 17.3 \\
\hline & 3. & $\begin{array}{l}3.32 \\
1.08\end{array}$ & $\begin{array}{r}.4539 \\
.1238\end{array}$ & $\begin{array}{l}13.7 \\
11.4\end{array}$ \\
\hline $\begin{array}{l}10-9-73 \\
10-26-73\end{array}$ & 3. & $\begin{array}{l}1.00 \\
69\end{array}$ & $\begin{array}{r}.1660 \\
.7780\end{array}$ & 16.6 \\
\hline $\begin{array}{l}10-26-73 \\
10-26-73\end{array}$ & 3. & $\begin{array}{l}.69 \\
.52\end{array}$ & $\begin{array}{l}.7789 \\
.0163\end{array}$ & $\begin{array}{r}112.4 \\
3.2\end{array}$ \\
\hline $11-9-73$ & 3. & .16 & .0690 & 44,5 \\
\hline $11-9.73$ & 3. & .04 & .0262 & 67.4 \\
\hline $\begin{array}{l}11-9-73 \\
11-9-73\end{array}$ & 3. & $\begin{array}{r}11 \\
.05\end{array}$ & $\begin{array}{r}.0291 \\
0309\end{array}$ & $\begin{array}{l}26,4 \\
59,0\end{array}$ \\
\hline $\begin{array}{l}11-9-73 \\
11-9-73\end{array}$ & 3. & $\begin{array}{l}.05 \\
.04\end{array}$ & .0168 & 42.4 \\
\hline $11-9-73$ & 3. & .13 & .0834 & 64.9 \\
\hline $11-23-73$ & 3. & .07 & .0218 & 32.6 \\
\hline $11-23-73$ & 3. & .01 & .0044 & 50.4 \\
\hline $\begin{array}{l}11-23-73 \\
11-23-73\end{array}$ & 3. & .03 & .0141 & $\begin{array}{r}27.5 \\
964.0\end{array}$ \\
\hline $11-23-73$ & 3. & .03 & .0132 & 51.0 \\
\hline $11-23-73$ & 7 & .03 & & 33.8 \\
\hline $11-23-73$ & & .06 & .0171 & 29.2 \\
\hline
\end{tabular}


ARITHMETIC AND LOGARITHMIC (BASE 10) RATIOS OF

CHLOROPHYLL-A $\left(\mu \mathrm{g} / \mathrm{cm}^{2}\right)$ FOR HEATED/

CONTROLS STATIONS

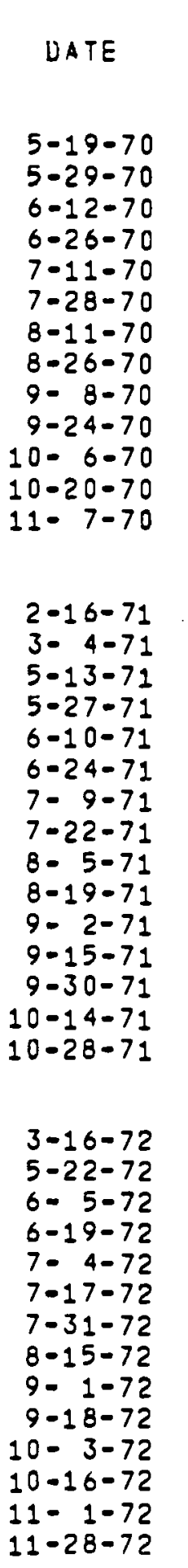

$$
\begin{array}{rrr}
\text { ARITHMETIC RATIOS } \\
3 / 7 & 6 / 9 & 11 / 2 \\
.0 .0 & .0 .0 & . .-0 \\
2.500 & .263 & .000 \\
.000 & .276 & .400 \\
.571 & .231 & .545 \\
.000 & .599 & .045 \\
.000 & 2.380 & .384 \\
.000 & .969 & 1.358 \\
.000 & .000 & .986 \\
1.307 & .000 & .662 \\
1.090 & .901 & .805 \\
.475 & 1.223 & .596 \\
1.854 & .906 & .731 \\
.811 & 3.198 & .837 \\
1.968 & 1.707 & .195
\end{array}
$$

\begin{tabular}{|c|c|c|}
\hline $3 / 7$ & $6 / 9$ & $11 / 2$ \\
\hline$-\infty$ & $\infty-\infty$ & $-\infty$ \\
\hline $\begin{array}{r}.398 \\
.000 \\
-.243 \\
.000 \\
.000 \\
.000 \\
.000 \\
.1116 \\
.037 \\
-.323 \\
.268 \\
. .091 \\
.294\end{array}$ & $\begin{array}{r}-.580 \\
-.559 \\
-.636 \\
-.223 \\
.377 \\
-.014 \\
.000 \\
.000 \\
-.045 \\
.037 \\
-.043 \\
.505 \\
.23 ?\end{array}$ & $\begin{array}{r}-.398 \\
-.263 \\
-1.342 \\
-.416 \\
-.133 \\
-.006 \\
-.179 \\
-.094 \\
-.0224 \\
-.136 \\
-.077 \\
-.710\end{array}$ \\
\hline
\end{tabular}

$\begin{array}{rrr}.000 & .000 & .000 \\ 1.000 & .000 & .000 \\ 13.400 & .277 & .083 \\ 3.800 & .146 & .280 \\ .000 & .916 & .007 \\ 1.922 & 1.397 & .130 \\ .000 & .858 & .181 \\ .000 & .540 & .306 \\ .887 & 1.003 & 1.080 \\ 1.188 & .851 & 1.750 \\ 1.182 & .474 & 1.387 \\ .915 & .412 & 3.045 \\ .804 & .158 & 4.682 \\ .177 & .750 & .091 \\ 1.276 & .000 & .000\end{array}$

$\begin{array}{rrr}.000 & .000 & .000 \\ .429 & .347 & .213 \\ 3.222 & .783 & .677 \\ 2.139 & .557 & 1.943 \\ .741 & .866 & 1.266 \\ .861 & .982 & .655 \\ .000 & .000 & .000 \\ .000 & .000 & .000 \\ 2.255 & .383 & .133 \\ 1.128 & 1.050 & 1.522 \\ .881 & 1.479 & 1.254 \\ 1.141 & 1.607 & 1.037 \\ 5.386 & 7.097 & 3.594 \\ .000 & .652 & .000\end{array}$

LOGARI THMIC (SASE 10) RATIOS

$\begin{array}{lll}.000 & .000 & .000 \\ .000 & .000 & .000\end{array}$

$1.127-.558-1.082$

$.580-.835 \quad-.553$

$.000 \quad-.038-2.185$

$\begin{array}{lll}.284 & .145 & -.887\end{array}$

$.000 \quad-.066-.743$

$.000 \quad-.263 \quad-.515$

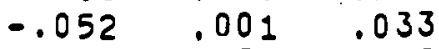

$.075 \quad-.070 \quad .243$

$\begin{array}{lll}.073 & . .324 \quad .142\end{array}$

$\begin{array}{lll}-.039 & -.386 & .484\end{array}$

$\begin{array}{llll}-.095 & -.801 & .670\end{array}$

$-.752-.125-1.043$

$.106 \quad .000 \quad .000$

$\begin{array}{rrr}.000 & .000 & .000 \\ . .368 & -.040 & -.071 \\ .508 & -.0106 & -.169 \\ .330 & -. .254 & .288 \\ -.130 & -.063 & .102 \\ . .065 & -.008 & -.0184 \\ .000 & .000 & .000 \\ .000 & .000 & .000 \\ .353 & -.017 & -.077 \\ .052 & .021 & .182 \\ . .055 & .170 & .098 \\ .057 & .0206 & .016 \\ .731 & .051 & .556 \\ .000 & -.0186 & .000\end{array}$


ARITHMETIC AND LOGARITHMIC (BASE 10) RATIOS OF

CHLOROPHYLL-A $\left(\mu \mathrm{g} / \mathrm{cm}^{2}\right)$ FOR HEATED/

CONTROLS STATIONS

\section{DATE}
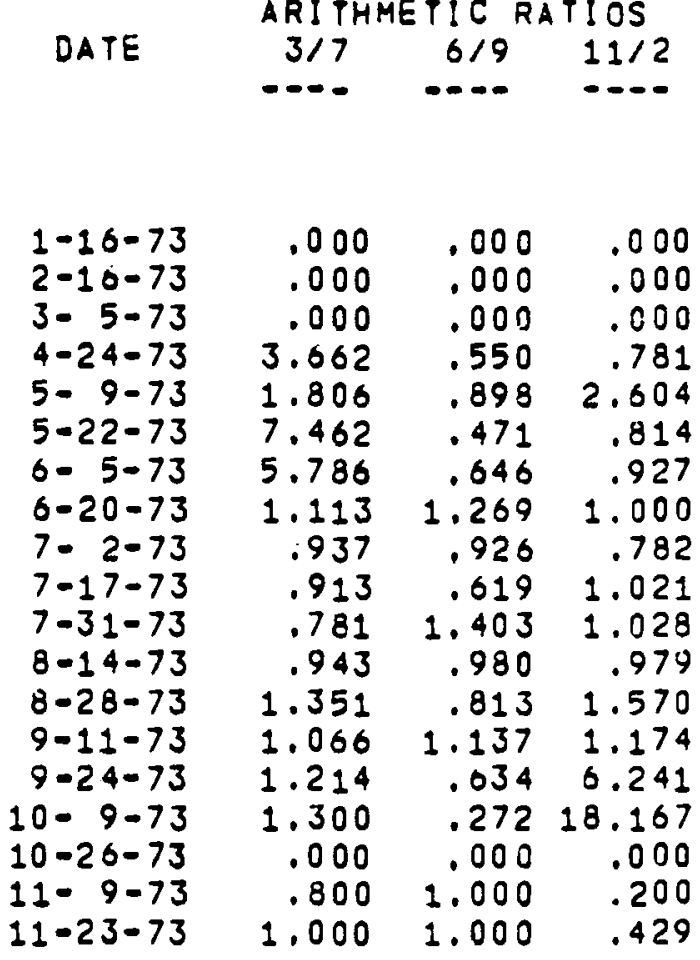

$\begin{array}{rrr}.000 & .000 & .000 \\ .000 & .000 & .000 \\ .000 & .000 & .000 \\ 3.602 & .550 & .781 \\ 1.806 & .898 & 2.604 \\ 7.462 & .471 & .814 \\ 5.786 & .646 & .927 \\ 1.113 & 1.269 & 1.000 \\ .937 & .926 & .782 \\ .913 & .619 & 1.021 \\ .781 & 1.403 & 1.028 \\ .943 & .980 & .979 \\ 1.351 & .813 & 1.570 \\ 1.066 & 1.137 & 1.174 \\ 1.214 & .034 & 6.241 \\ 1.300 & .272 & 18.167 \\ .000 & .000 & .000 \\ 1.800 & 1.000 & .200 \\ 1.000 & 1.000 & .429\end{array}$

\section{$5-23-74$}

$6-10-74$

$6-25-74$

$7-9-74$

$7-23-74$

$8-5-74$

$8-20-74$

$9-4-74$

$9-19-74$

$10-2-74$

$10-16-74$

$10-31-74$

$\begin{array}{rrr}.000 & .080 & .029 \\ .000 & 1.081 & .522 \\ 5.079 & .662 & .616 \\ 1.521 & .734 & .825 \\ .804 & 1.299 & .523 \\ 1.162 & .740 & .982 \\ .846 & 1.122 & 1.146 \\ 1.552 & .380 & .782 \\ 1.327 & 1.126 & 1.857 \\ .991 & .605 & .497 \\ .920 & 1.434 & 4.560 \\ .679 & .673 & .793\end{array}$

LOGARITHMIC (BASE 10) RATIOS

$3 / 7 \quad 6 / 9 \quad 11 / 2$ $\begin{array}{rrr}.000 & -1.099 & -1.540 \\ .000 & .034 & -.282 \\ .706 & -.179 & -.211 \\ .182 & -.134 & -.083 \\ -.095 & .114 & -.082 \\ .065 & -.131 & -.008 \\ -.073 & .050 & .059 \\ .191 & -.420 & -.107 \\ .123 & .052 & .069 \\ -.004 & -.213 & -.304 \\ -.036 & .157 & .059 \\ -.168 & -.172 & -.101\end{array}$ 
STEM AND LEAF DISPLAYS OF LOGARITHMIC RATIOS

OF INDIVIDUAL HEATED/CONTROL STATIONS FOR CHLOROPHYLL-A $\left(\mu \mathrm{gm} / \mathrm{cm}^{2}\right)$

RATIO STATIONS $3 / 7$

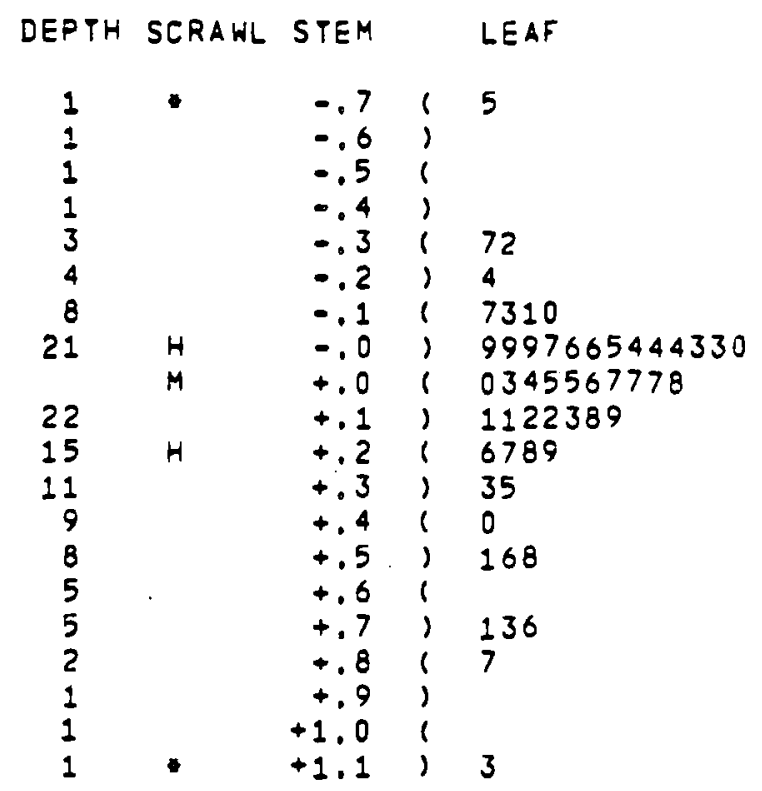

RATIO STATIONS $6 / 9$
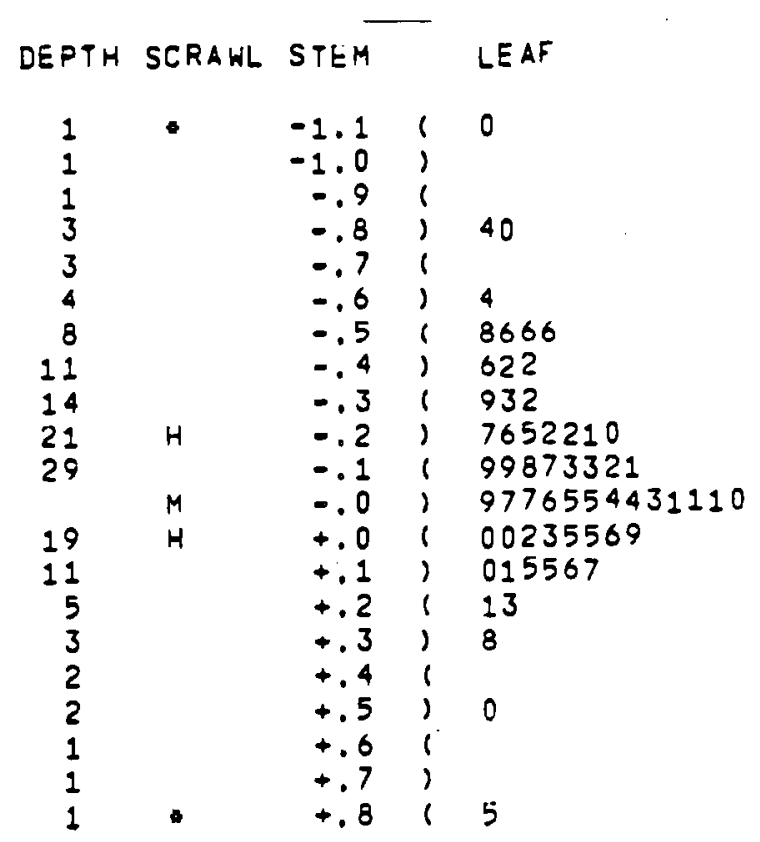

RATIO STATIONS $11 / 2$

DEPTH SCRAWL STEM LEAF

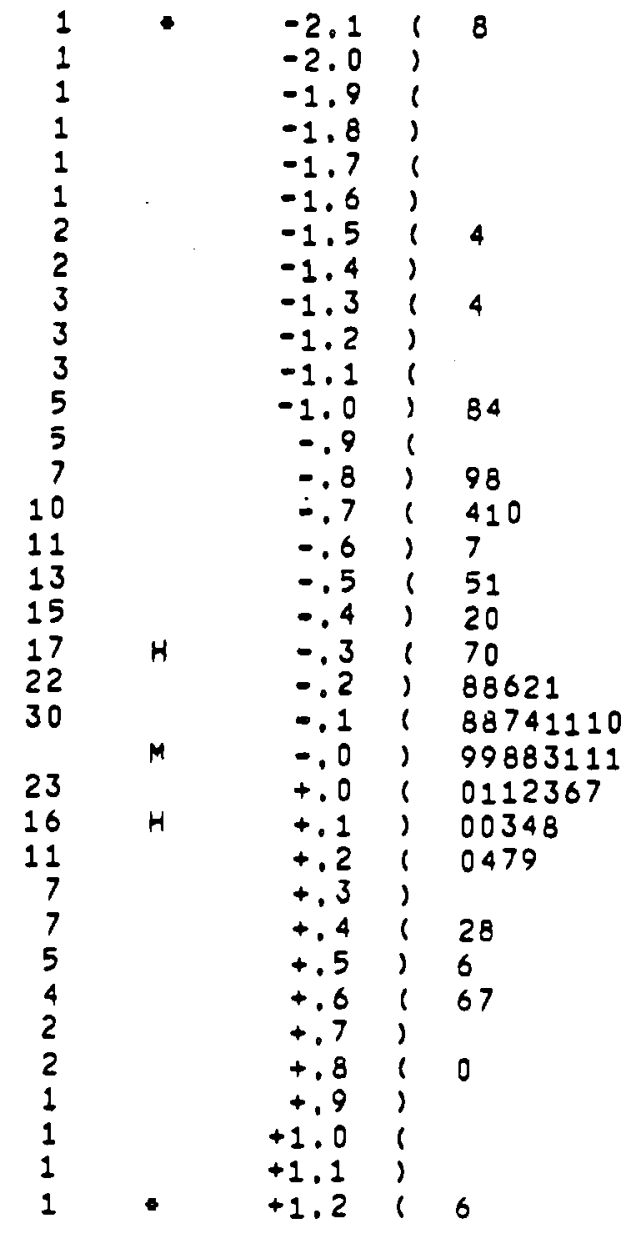

I 
STEM AND LEAF OISPLAYS OF LOGARITHMIC RATIOS

OF INDIVIDUAL HEATED/CONTROL STATIONS FOR CHLOROPHYLL-A

\section{Arithmetic Display}

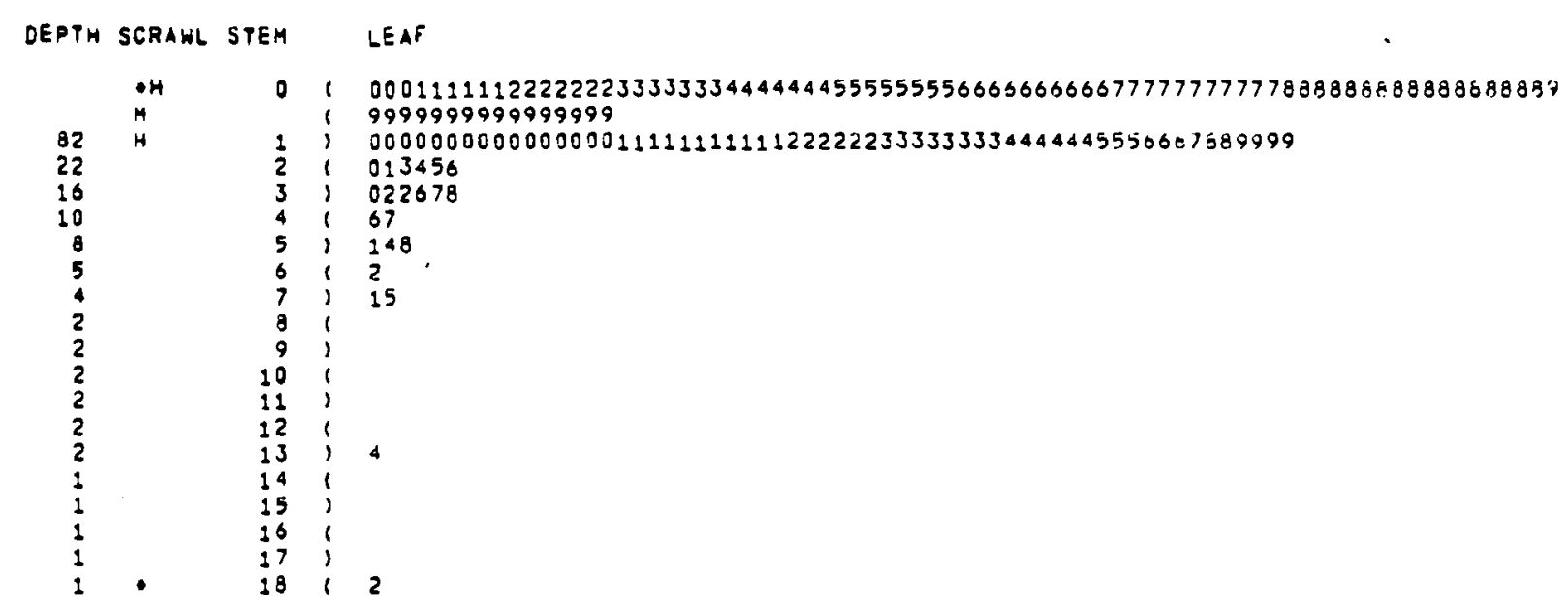

\section{Logarithmic Display}

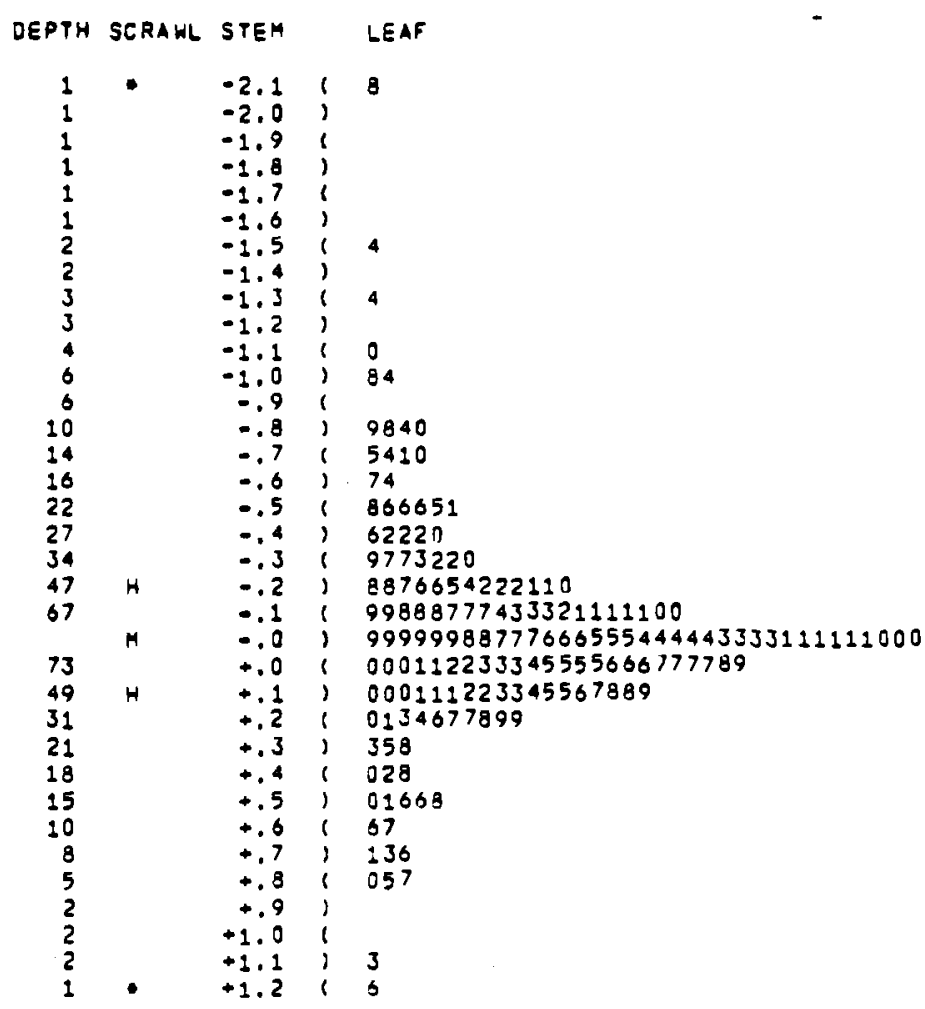


APPENDIX H

ELECTROFISHING DATA (CATCH/EFFORT) 

COURSEFISH CATCH/UNIT EFFORT BY ELECTROFISHING FOR 1973

\begin{tabular}{|c|c|c|c|c|c|}
\hline \multirow[b]{3}{*}{ Month } & \multirow{3}{*}{$\begin{array}{l}\text { Sampling } \\
\text { Sequence }\end{array}$} & \multicolumn{4}{|c|}{ Electrofishing Sector Location } \\
\hline & & & & Discharge Ar & \\
\hline & & Control & Outer & Intermediate & Immediate \\
\hline Mar & $\begin{array}{l}1 \\
2\end{array}$ & 86 & & & \\
\hline Apr & $\begin{array}{l}1 \\
2\end{array}$ & 120 & & 146 & \\
\hline May & $\begin{array}{l}1 \\
2 \\
3 \\
4\end{array}$ & 116 & $\begin{array}{r}274 \\
253 \\
98 \\
225\end{array}$ & 213 & $\begin{array}{r}48 \\
24 \\
22 \\
150\end{array}$ \\
\hline Jun & $\begin{array}{l}1 \\
2 \\
3 \\
4 \\
5 \\
6 \\
7 \\
8 \\
9\end{array}$ & $\begin{array}{r}122 \\
141 \\
42\end{array}$ & $\begin{array}{r}150 \\
71 \\
153 \\
76 \\
104 \\
174 \\
24\end{array}$ & $\begin{array}{l}262 \\
148 \\
141\end{array}$ & $\begin{array}{r}30 \\
38 \\
70 \\
38 \\
10 \\
6 \\
33 \\
5 \\
8\end{array}$ \\
\hline Jul & $\begin{array}{l}1 \\
2 \\
3 \\
4\end{array}$ & 46 & $\begin{array}{r}181 \\
79 \\
160 \\
93\end{array}$ & $\begin{array}{r}49 \\
131\end{array}$ & $\begin{array}{l}55 \\
76\end{array}$ \\
\hline Aug & $\begin{array}{l}1 \\
2 \\
3 \\
4 \\
5 \\
6\end{array}$ & $\begin{array}{l}90 \\
25\end{array}$ & $\begin{array}{r}154 \\
98 \\
47 \\
49\end{array}$ & $\begin{array}{r}62 \\
90 \\
47 \\
56 \\
5\end{array}$ & $\begin{array}{r}14 \\
4 \\
5 \\
16 \\
4 \\
19\end{array}$ \\
\hline Sep & $\begin{array}{l}1 \\
2 \\
3\end{array}$ & 61 & $\begin{array}{r}60 \\
54 \\
145\end{array}$ & $\begin{array}{l}154 \\
148 \\
270\end{array}$ & $\begin{array}{l}10 \\
13 \\
24\end{array}$ \\
\hline
\end{tabular}


COURSEFISH CATCH/UNIT EFFORT BY ELECTROFISHING FOR 1974

\begin{tabular}{|c|c|c|c|c|c|}
\hline \multirow[b]{3}{*}{ Month } & \multirow{3}{*}{$\begin{array}{l}\text { Sampling } \\
\text { Sequence }\end{array}$} & \multicolumn{4}{|c|}{ Electrofishing Sector Location } \\
\hline & & & & Discharge A & \\
\hline & & Control & outer & Intermediate & Immediate \\
\hline Mar & $\begin{array}{l}1 \\
2\end{array}$ & & & & \\
\hline Apr & $\begin{array}{l}1 \\
2\end{array}$ & $\begin{array}{r}54 \\
129\end{array}$ & $\begin{array}{l}44 \\
87\end{array}$ & $\begin{array}{r}102 \\
98\end{array}$ & $\begin{array}{l}68 \\
47\end{array}$ \\
\hline May & $\begin{array}{l}1 \\
2 \\
3 \\
4\end{array}$ & $\begin{array}{l}106 \\
233 \\
130 \\
133\end{array}$ & $\begin{array}{l}126 \\
251 \\
142 \\
150\end{array}$ & $\begin{array}{l}178 \\
118 \\
208 \\
141\end{array}$ & $\begin{array}{r}66 \\
51 \\
264 \\
147\end{array}$ \\
\hline Jun & $\begin{array}{l}1 \\
2 \\
3 \\
4 \\
5 \\
6 \\
7 \\
8 \\
9\end{array}$ & $\begin{array}{l}162 \\
189\end{array}$ & $\begin{array}{l}223 \\
162 \\
264 \\
171\end{array}$ & $\begin{array}{l}155 \\
365 \\
347 \\
160 \\
237\end{array}$ & $\begin{array}{l}58 \\
16 \\
45 \\
52\end{array}$ \\
\hline Jul & $\begin{array}{l}1 \\
2 \\
3 \\
4\end{array}$ & $\begin{array}{l}81 \\
34\end{array}$ & $\begin{array}{l}41 \\
53 \\
47\end{array}$ & 21 & $\begin{array}{r}14 \\
0\end{array}$ \\
\hline Aug & $\begin{array}{l}1 \\
2 \\
3 \\
4 \\
5 \\
6\end{array}$ & $\begin{array}{r}145 \\
70\end{array}$ & $\begin{array}{r}120 \\
97\end{array}$ & & \\
\hline Sep & $\begin{array}{l}1 \\
2 \\
3\end{array}$ & & & & \\
\hline
\end{tabular}




\section{GAME FISH CATCH/UNIT EFFORT ELECTROFISHING FOR 1973}

\begin{tabular}{|c|c|c|c|c|c|}
\hline \multirow[b]{3}{*}{ Month } & \multirow{3}{*}{$\begin{array}{l}\text { Sampling } \\
\text { Sequence }\end{array}$} & \multicolumn{4}{|c|}{ Electrofishing Sector Location } \\
\hline & & & & Discharge Ar & \\
\hline & & Control & Outer & Intermediate & Immediate \\
\hline Mar & $\begin{array}{l}1 \\
2\end{array}$ & & & & \\
\hline Apr & $\begin{array}{l}1 \\
2\end{array}$ & $\begin{array}{l}0 \\
1\end{array}$ & $\begin{array}{l}0 \\
0\end{array}$ & $\begin{array}{l}0 \\
0\end{array}$ & $\begin{array}{r}21 \\
6\end{array}$ \\
\hline May & $\begin{array}{l}1 \\
2 \\
3 \\
4\end{array}$ & $\begin{array}{r}1 \\
7 \\
2 \\
49\end{array}$ & $\begin{array}{l}0 \\
0 \\
0 \\
0\end{array}$ & $\begin{array}{r}0 \\
14 \\
14 \\
0\end{array}$ & $\begin{array}{l}9 \\
5 \\
5 \\
0\end{array}$ \\
\hline Jun & $\begin{array}{l}1 \\
2 \\
3 \\
4 \\
5 \\
6 \\
7 \\
8 \\
9\end{array}$ & $\begin{array}{l}36 \\
12\end{array}$ & $\begin{array}{r}9 \\
0 \\
62 \\
0\end{array}$ & $\begin{array}{r}0 \\
61 \\
13 \\
27 \\
65\end{array}$ & $\begin{array}{r}13 \\
0 \\
0 \\
0\end{array}$ \\
\hline JuT & $\begin{array}{l}1 \\
2 \\
3 \\
4\end{array}$ & $\begin{array}{l}6 \\
6\end{array}$ & $\begin{array}{r}26 \\
0 \\
0\end{array}$ & 0 & $\begin{array}{r}10 \\
0\end{array}$ \\
\hline Aug & $\begin{array}{l}1 \\
2 \\
3 \\
4 \\
5 \\
6\end{array}$ & $\begin{array}{r}7 \\
14\end{array}$ & $\begin{array}{r}0 \\
11\end{array}$ & & \\
\hline Sep & $\begin{array}{l}1 \\
2 \\
3\end{array}$ & & & & \\
\hline
\end{tabular}




\section{GAME FISH CATCH/UNIT EFFORT ELECTROFISHING FOR 1974}

\begin{tabular}{|c|c|c|c|c|c|}
\hline \multirow[b]{3}{*}{ Month } & \multirow{3}{*}{$\begin{array}{l}\text { Sampling } \\
\text { Sequence }\end{array}$} & \multicolumn{4}{|c|}{ Electrofishing Sector Location } \\
\hline & & & & Discharge Ar & \\
\hline & & Control & Outer & Intermediate & Immediate \\
\hline Mar & $\begin{array}{l}1 \\
2\end{array}$ & & & & \\
\hline Apr & $\begin{array}{l}1 \\
2\end{array}$ & $\begin{array}{l}0 \\
1\end{array}$ & $\begin{array}{l}0 \\
0\end{array}$ & $\begin{array}{l}0 \\
0\end{array}$ & $\begin{array}{r}21 \\
6\end{array}$ \\
\hline May & $\begin{array}{l}1 \\
2 \\
3 \\
4\end{array}$ & $\begin{array}{r}1 \\
7 \\
2 \\
49\end{array}$ & $\begin{array}{l}0 \\
0 \\
0 \\
0\end{array}$ & $\begin{array}{r}0 \\
14 \\
14 \\
0\end{array}$ & $\begin{array}{l}9 \\
5 \\
5 \\
0\end{array}$ \\
\hline Jun & $\begin{array}{l}1 \\
2 \\
3 \\
4 \\
5 \\
6 \\
7 \\
8 \\
9\end{array}$ & $\begin{array}{l}36 \\
12\end{array}$ & $\begin{array}{r}9 \\
0 \\
62 \\
0\end{array}$ & $\begin{array}{r}0 \\
61 \\
13 \\
27 \\
65\end{array}$ & $\begin{array}{r}13 \\
0 \\
0 \\
0\end{array}$ \\
\hline JuT & $\begin{array}{l}1 \\
2 \\
3 \\
4\end{array}$ & $\begin{array}{l}6 \\
6\end{array}$ & $\begin{array}{r}26 \\
0 \\
0\end{array}$ & 0 & $\begin{array}{r}10 \\
0\end{array}$ \\
\hline Aug & $\begin{array}{l}1 \\
2 \\
3 \\
4 \\
5 \\
6\end{array}$ & $\begin{array}{r}7 \\
14\end{array}$ & $\begin{array}{r}0 \\
11\end{array}$ & & \\
\hline Sep & $\begin{array}{l}1 \\
2 \\
3\end{array}$ & & & & \\
\hline
\end{tabular}




\section{DISTRIBUTION}

No. of

Copies

\section{OFFSITE}

A. A. Churm

ERDA Chicago Patent Group

9800 South Cass Avenue

Argonne, IL 60439

3 M. Jinks, Chief Mail and Files

USNRC Central Files

Washington, DC 20555

245 ERDA Technical Information Center

For Basic Distribution Under NRC-1

P. G. Voill leque

ERDA Health Services Laboratory

Idaho Falls, ID 83401

H. T. Peterson

USNRC Office of Standards

Development

Washington, DC 20555
No. of

Copies

ONSITE

ERDA Richland Operations office

P. G. Holsted

Atlantic Richfield Hanford Company

G. E. Backman

United Nuclear Industries, Inc.

A. E. Engler

Hanford Engineering Development Laboratory

G. D. Carpenter

55 Battelle-Northwest

K. L. Gore (10)

J. L. Helbling (2)

C. Hudges

J. Johnston

L. D. Kannberg (10)

J. Mahaffey

J. M. Thomas (10)

D. G. Watson (10)

B. E. Vaughan (2)

Technical Information Files (5)

Technical Publications (3) 
